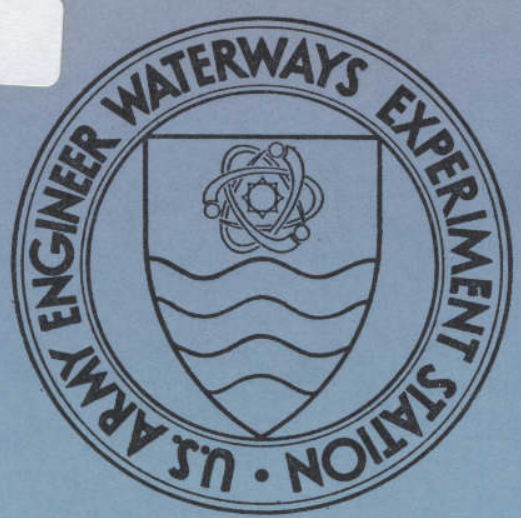

TECHNICAL REPORT N-70-I0

\title{
SURVEY OF GULF COAST \\ STRUCTURAL DAMAGE RESULTING FROM HURRICANE CAMILLE, AUGUST 1969 \\ Final Report
}
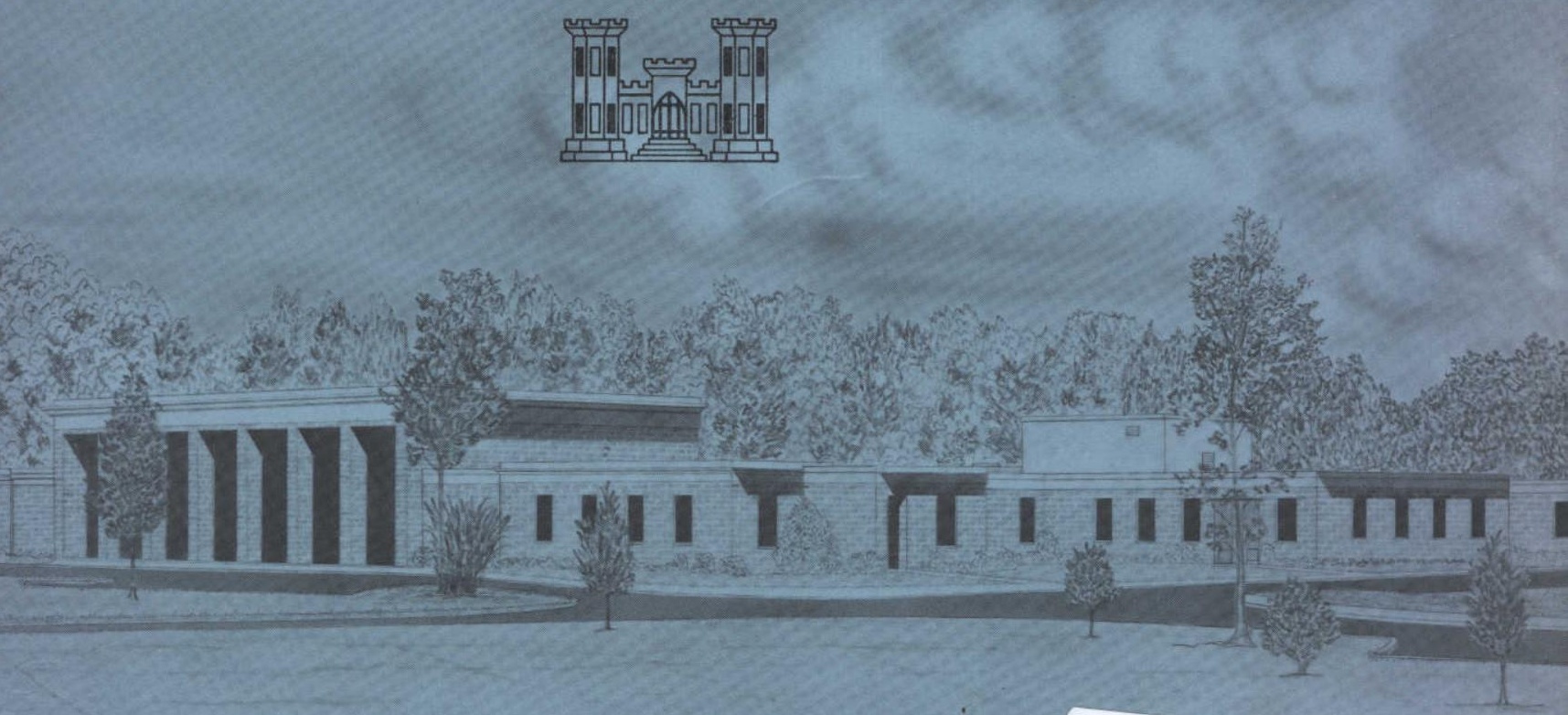

April 1970

metadc 304015

Conducted for Office of Civil Defense, Office of the Secretary of the Army

Washington, D. C. 20310

Under Work Order No. DAHC20-68-W-0192, Work Unit II27E

By U. S. Army Engineer Waterways Experiment Station, Vicksburg, Mississippi 
Destroy this report when it is no longer needed.

Do not return it to the originator.

The findings in this report are not to be construed as an official Department of the Army position unless so designated by other authorized documents. 


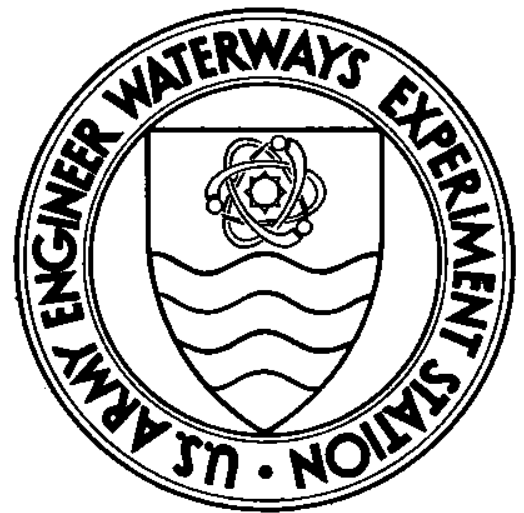

TECHNICAL REPORT N-70-10

SUMMARY OF

\title{
SURVEY OF GULF COAST STRUCTURAL DAMAGE RESULTING FROM HURRICANE CAMILLE, AUGUST 1969
}

\author{
Final Report
}

by

M. E. Criswell, R. S. Cummins

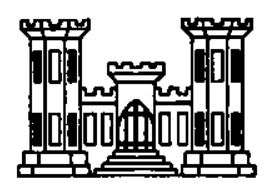

April 1970

OCD REVIEW NOTICE

This report has been reviewed in the Office of Civil Defense and approved for publication. Approval does not signify that the contents necessarily reflect the views and policies of the Office of Civil Defense.

Conducted for Office of Civil Defense, Office of the Secretary of the Army Washington, D. C. 20310

Under Work Order No. DAHC20-68-W-0192, Work Unit II27E

By U. S. Army Engineer Waterways Experiment Station, Vicksburg, Mississippi 

Hurricane Camille, a relatively small but very intense tropical storm, struck and heavily damaged the Mississippi River Delta area below New Orleans, Louisiana, and the Mississippi. Gulf Coast area on late 17 August 1969. The storm center came ashore near Pass Christian, Mississippi. Winds reportedly in excess of $190 \mathrm{mph}$ and tides at least 16 feet above normal and with large wind-driven waves accompanied Camille and caused extensive damage to structures located along its path.

This report describes in qualitative terms and with photographs the damage to structures seen by an OCD-sponsored inspection team. This team consisted of the authors and two staff members from URS Corporation sent to the damaged areas on 22-26 August.

The damage in the Mississippi Delta area was primarily caused by high water moving in from the Gulf of Mexico to the east. Flooding was very severe over large areas.

The low-lying areas of the Mississippi Gulf Coast immediately along the shoreline were most heavily damaged. Damage in these areas appeared to have been primarily a result of the battering from wind-driven waves riding atop the high water. A distinct debris line was often seen marking the limit of wave damage. Damage from wind was visible along the coast and extended inland along Camille's path. Much of the wind damage resulted from the falling of trees and branches onto structures, highways, and overhead lines.

Much masonry (block) construction along the coast collapsed completely, probably when the first-floor bearing walls failed. Older wooden frame residences along the coast often withstood the storm comparatively well. Damage in downtown Gulfport and Biloxi was primarily limited to water damage, and damage to signs, awnings, and lightly constructed buildings. No sizable multistory building seen which received only wind loading collapsed from inadequate lateral resistance.

Based on the storm damage observed, the following conclusions were reached:

1. Many low buildings, especially masonry structures, are too 
dependent upon vertical loads and forces for their stability; their resistance to lateral loads is small.

2. Connections and other "details" essential for the building components to act together as a structure are too often given inadequate attention by both designer and builder. Need for adequate inspection during construction was also indicated.

3. The possibility of any hurricane loading did not appear to have been adequately recognized in the design of much recent construction in the coastal areas. However, designing structures in the immediate coastal areas to survive with little or no damage the winds and water action of unusual storms such as Camille may not be economically feasible.

4. Primarily because of the uncertainties concerning the loads acting on most of the structures in the storm area, quantitative information on the strength and performance of these buildings will be difficult to determine.

5. The preponderance of water damage in many areas and the lack of overpressure loadings and ground motion preclude the direct projection of the storm damage to predict the damage from a nuclear blast loading. 


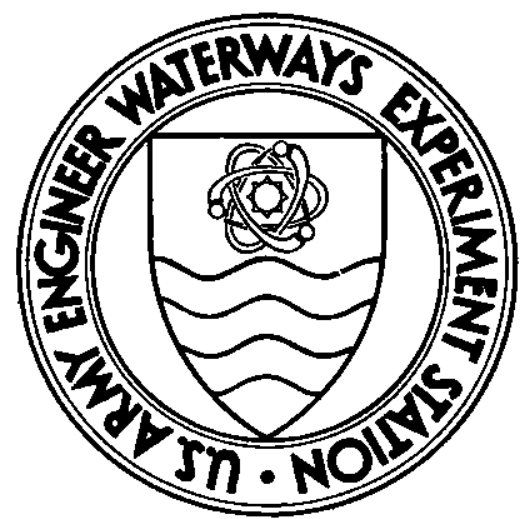

TECHNICAL REPORT N-70-10

\title{
SURVEY OF GULF COAST STRUCTURAL DAMAGE RESULTING FROM HURRICANE CAMILLE, AUGUST 1969
}

\author{
Final Report
}

by

M. E. Criswell, R. S. Cummins

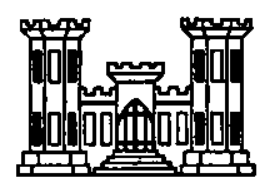

April 1970

OCD REVIEW NOTICE

This report has been reviewed in the Office of Civil Defense and approved for publication. A pproval does not signify that the contents necessarily reflect the views and policies of the Office of Civil Defense.

Conducted for Office of Civil Defense, Office of the Secretary of the Army

$$
\text { Washington, D. C. } 20310
$$

Under Work Order No. DAHC20-68-W-0192, Work Unit II27E

By U. S. Army Engineer Waterways Experiment Station, Vicksburg, Mississippi 



\section{ABSTRACT}

This report describes the damage to structures seen by an inspection team sent to the Mississippi and Louisiana Gulf Coast regions after Hurricane Camille, a very violent but relatively small tropical storm, came ashore west of Gulfport, Mississippi, late on 17 August 1969. Many photographs of the storm damage are included.

Extensive damage resulted both from the unusually high winds accompanying Camille and from the extremely high tides coupled with wind-driven waves. Damage was greatest in low areas immediately adjacent to the coastline.

Because of uncertainties of the material properties for the various buildings and particularly of the loading, the report presents mainly qualitative results.

More ductile buildings, such as heavy wooden frame construction, appeared to have survived the storm best.

The storm damage indicated a need for more lateral strength in buildings, especially masonry structures, and for more adequate design of connections and other details. 
This report was prepared by Messrs. Marvin E. Criswell and Reid S. Cummins under the general supervision of Mr. G. L. Arbuthnot, Jr., Chief, Nuclear Weapons Effects Division, and under the direct supervision of Mr. W. J. Flathau, Chief, Protective Structures Branch, U. S. Army Engineer Waterways Experiment Station.

The report is primarily a trip report of the inspection trip made by the authors and two professional staff members of the URS Corporation to the Gulf Coast regions heavily damaged by Hurricane Camille in August 1969. This inspection trip was sponsored by the office of Civil Defense (OCD) under the direction of Dr. J. O. Buchanan, Deputy Assistant Director of Civil Defense (Research), through Mr. R. F. Stellar, Chief of the Joint Civil Defense Support Group of the Office, Chief of Engineers.

The authors wish to acknowledge Mr. James F. Halsey and Dr. Carl F. Miller, party members from URS, for their assistance both during and after the trip; the New Orleans District, Corps of Engineers, for their aid and for permission to use Figures 2.10 through 2.13 and 2.25 through 2.27; and the Weather Bureau at New Orleans for providing meteorological information on Camille.

Director of the Waterways Experiment Station during the preparation of this report was COL Levi A. Brown, CE. Technical Director was Mr. F. R. Brown. 
ABSTRACT- -

PREFACE--

CONVERSION FACTORS, BRITISH TO METRIC UNITS OF MEASUREMENT-_-

CHAPTER 1 INTRODUCTION-

1.1 Background-10

1.2 Scope and Purpose-....

1.3 Inspection Team Itinerary--1.

1.3.1 22 August-...

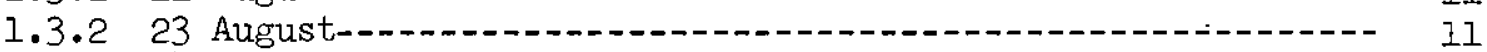

1.3.3 24-25 August---n- 26

1.3 .426 August-..- 12

CHAPIER 2 DAMAGE TO STRUCTURES FROM HURRICANE CAMTLLE-_..........

2.1 The Storm--

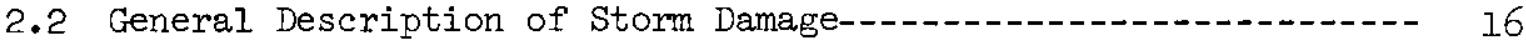

2.2.1 Mississippi River Delta, Louisiana-.-.-.-.-.-.-.-.-.- 16

2.2.2 Mississippi Gulf Coast---n-m 17

2.2.3 Inland Areas---.-.-- 19

2.3 Performance of Structural Types-----

2.3.1 Masonry Block Structures----_-

2.3.2 Wooden Frame Buildings-

2.3.3 Iight Steel or Concrete Frame Buildings-.................... 21

2.3.4 Heavier Business and Multistory Construction-_...-...-... 21

2.3.5 Buildings with Large Interior Areas: Schools, Churches, and Gymnasiums-.- 22

2.3.6 Marine Structures and Bridges--......

CHAPTER 3 CASE STUDTES OF STRUCTURAT DAMAGE--

3.1 State Dock-1- 83

3.2 Marine Iife Aquarium--

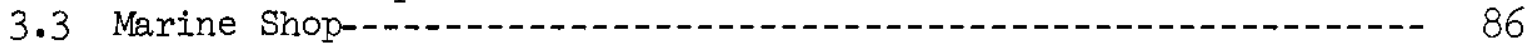

3.4 Pass Christian City Hall- 86

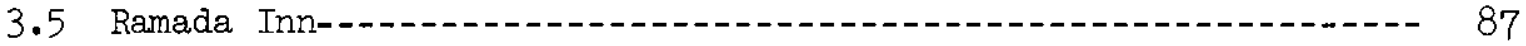

3.6 A\&P and Adjoining Shopping Complex

3.7 Gulf Plaza-n.-.... 88

3.8 Broadwater Beach Boat Marina-

3.9 Bay Saint Louis Bridge--n- 89

CHAPTER 4 DAMAGE TO COMMUNICATIONS, UTILITIES, AND AGRICULTURE--.-- 145

4.1 Highways-1- 145

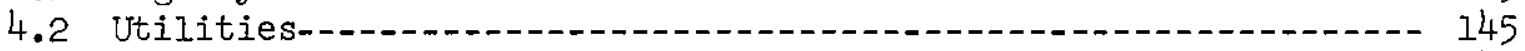

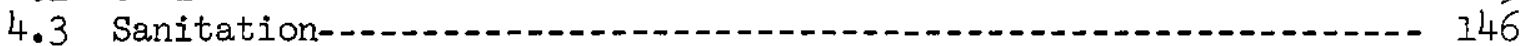

4.4 Trees and Agriculture--. 
CHAPIER 5 SUMMARY, CONCLUSIONS, AND RECOMMENDATIONS--..-151

5.1 Summary--15]

5.2 Conclusions-1...-. 152

5.3 Recommendations-_....... 153

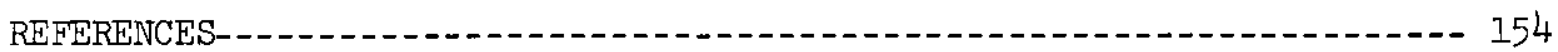

\section{FIGURES}

1.1 Flight itinerary and route-13

2.1 Hurricane Camille's path and winds-..................... 23

2.2 Fastest winds, miles per hour, 100-year period of recurrence-- 24

2.3 Path of Hurricane Camille-............ 25

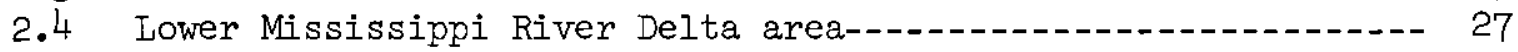

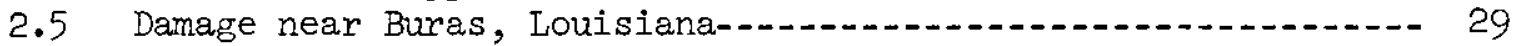

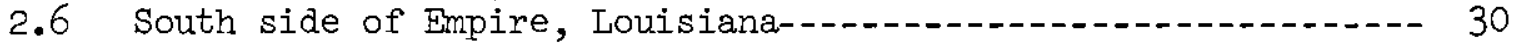

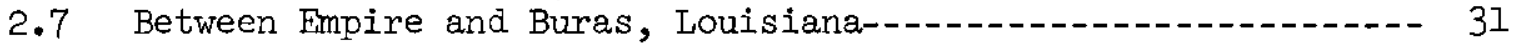

2.8 Near Buras, Louisiana-.......... 32

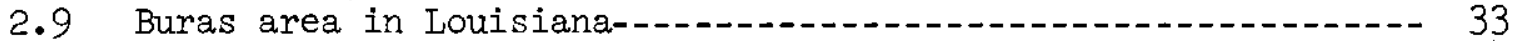

2.10 Home Place and Port Sulphur, Louisiana--....... 34

2.11 Back levee, near Buras, Louisiana-.......... 35

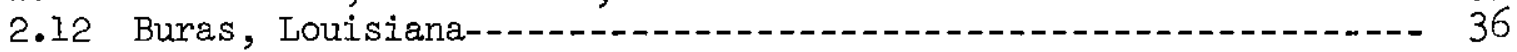

2.13 Below Buras, Louisiana-_....... 37

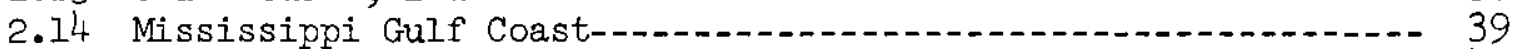

2.15 Residential area in west Gulfport, Mississippi-.-.-.-.-.-.- 41

2.16 Residential district in west Gulfport, Mississippi-......... 42

2.17 Residences and debris line in west Gulfport, Mississippi---.- 43

2.18 Remains of motels and apartments, Long Beach area.......... 44

2.19 Gulf Plaza and apartments, east Pass Christian area-......... 45

2.20 Motel building slab, between Pass Christian and Long Beach---- 46

2.21 East end of Pass Christian downtown area-1.............. 47

2.22 Pass Christian, Mississippi-...-...-. 48

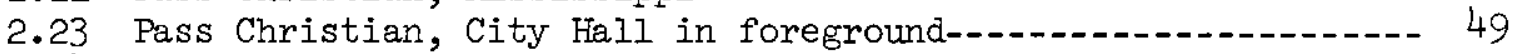

2.24 West Pass Christian, Mississippi-n... 50

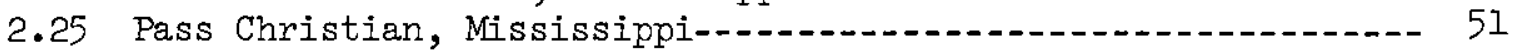

2.26 Henderson Point, on east shore of Saint Louis Bay,

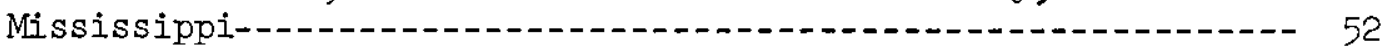

2.27 Debris at east end of Bay Saint Louis Bridge, Mississippi-...- 53

2.28 Tug and paper rolls in debris, west Gulfport, Mississippi---- 54

2.29 Debris from residences and Port facilities, west Gulfport,

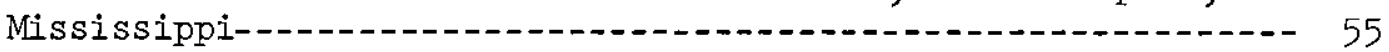

2.30 Tank floated in from harbor, west Gulfport, Mississippi-...-. 56

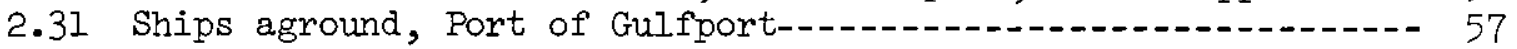

2.32 Barge, debris, and damaged residence, west Gulfport, Mississippi-.....-.... 58

2.33 Debris of a shopping center, Long Beach, Mississippi-----.--- 59

2.34 Destroyed residence from front doorsteps, Long Beach,

Mississippi-_-_._-_._._._. 60

2.35 Residence near Long Beach, Mississippi-.-................. 61

2.36 Boat ashore, east end of Biloxi, Mississippi-_.............. 62 
2.37 Commercial building, Back Bay of Biloxi, Mississippi-.......--

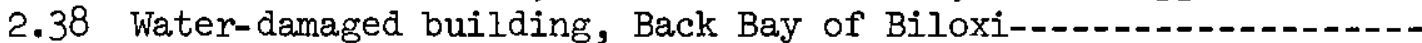

2.39 Oil storage tank floated inland, Back Bay of Biloxi--.-.--.--

2.40 Remains of brick and block residence, Long Beach area---.---.-

2.41 Motels, west of Biloxi, Mississippi-_-_...

2.42 Motel or apartment house, Long Beach area-...-...-

2.43 Richelieu Apartments (23 dead), Pass Christian, Mississippi---

2.44

2.45

2.46

2.47 Pool area, Gulf Villa Apartments, Long Beach area-.-..-..Gulf Villa Apartments, Long Beach area

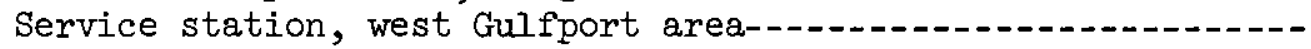
Collapsed frame house, between Biloxi and Gulfport,

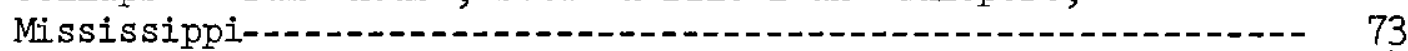

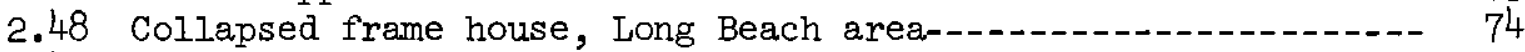

2.49 Residence, Long Beach, Mississippi-........................ 75

2.50 Steel frame recreation hall, Jones Memorial Park, Gulfport--.- 76

2.51 Frame restaurant structure, Biloxi, Mississippi---.---1--- 77

2.52 Frame motel structure, Biloxi, Mississippi-_-_-_..... 78

2.53 Concrete frame restaurant, Biloxi, Mississippi-........... 79

2.54 Gulfport business district from the south-_.......... 80

2.55 Poplarville High School, Poplarville, Mississippi-.........- 81

2.56 Pass Christian small-boat harbor, Pass Christian,

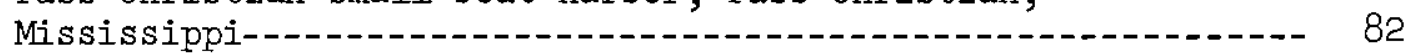

3.1 Close-up view of general construction of State Dock-......... 90

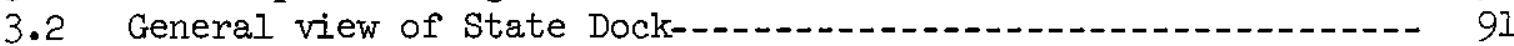

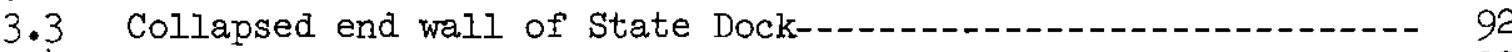

3.4 Close-up view of collapsed end wall of State Dock-..-.-.-.-.-. 93

3.5 Failure of tilt-up walls along west side of State Dock-......- 94

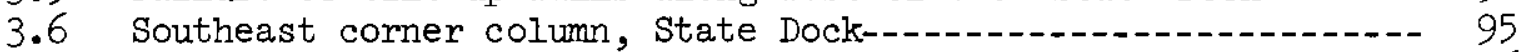

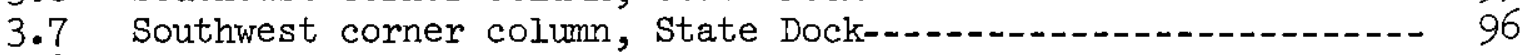

3.8 End-wall column and panel, State Dock-................... 97

3.9 Dowels at base of end-wall column, State Dock-............. 98

3.10 Ruptured bar on spandrel beam, State Dock-.............. 99

3.11 Buildings on east side of Port of Gulfport, Gulfport,

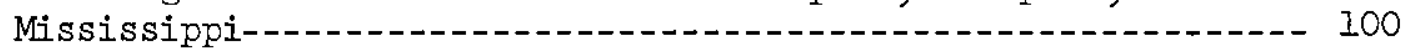

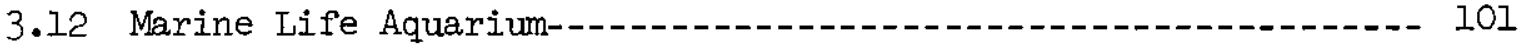

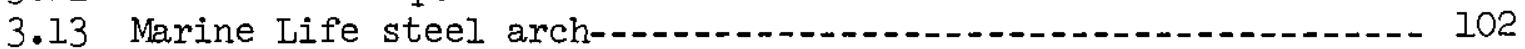

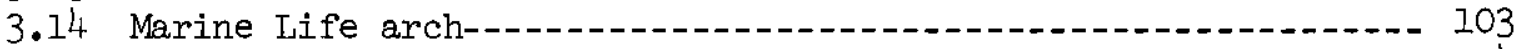

3.15 Center pier supporting west end of arch, Marine Life-........ 104

3.16 Southeast corner of Marine Life arch-..................... 105

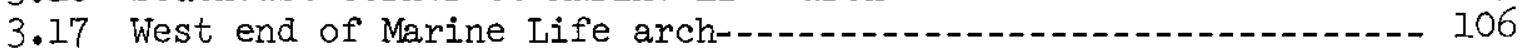

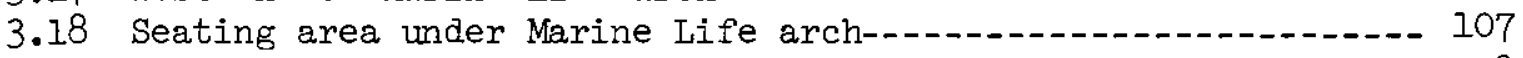

3.19 Seating area and arch at Marine Life-......................... 108

3.20 Close-up of seating area, Marine Life-...-.-.-.-.-.-109

3.21 Overhead view of beam failure over block wall, Marine Life---- 110

3.22 Side view of beam failure over block wall, Marine Life-...-.-. 111

3.23 Beam failed in torsion, seating area of Marine Life--------- 112

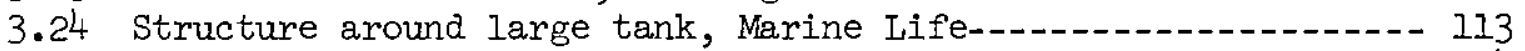

3.25 Reinforcement corrosion in a beam, Marine Life-............ 114

3.26 Reinforcement corrosion in a slab, Marine Life-.............- 115

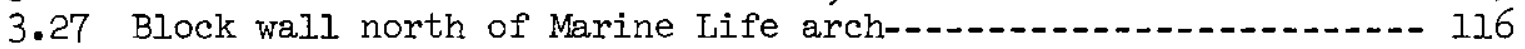




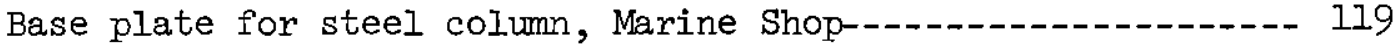

3.31

Weld failure of a plate girder, Marine Shop-........... 120

3.32

Pass Christian City Hall-_......

Businesses behind and east of Pass Christian City Hall-...-.-- 122

Area east of Pass Christian City Hall-_................... 123

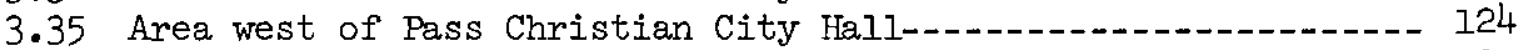

3.36 Wall damage, Pass Christian City Hall-................... 125

3.37 Emergency Operating Center, Pass Christian City Hall--.-.-.-- 126

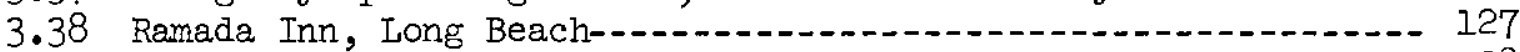

3.39 East wall of Ramada Inn main building-.................... 128

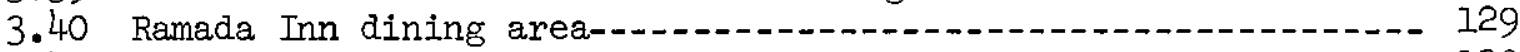

3.41 Front of A\&P store, Long Beach-............................... 130

3.42 Side view of A\&P with remains of Walgreen's in foreground,

Long Beach-.-...... 131

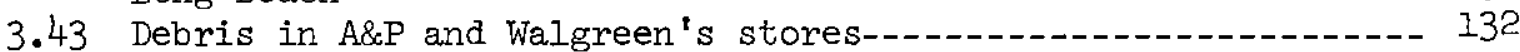

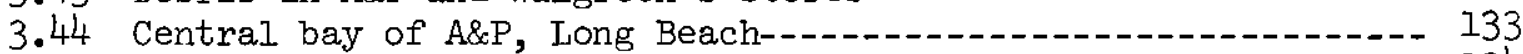

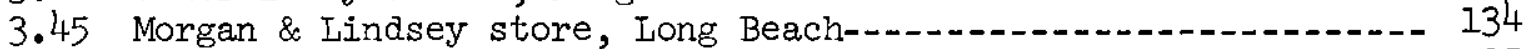

3.46 Gulf Plaza shopping center-.-...-...- 135

3.47 Interior of Gulf Plaza shopping center-...................... 136

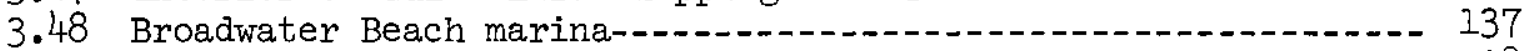

3.49 Northeast corner of Broadwater Beach marina, looking north--.- 138

3.50 Northeast corner of Broadwater Beach marina, looking west-.-.- 139

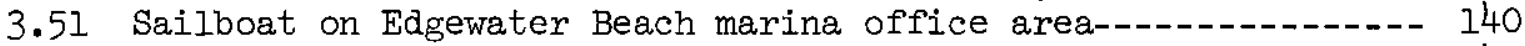

3.52 Bay Saint Louis Bridge, looking east................... 141

3.53 Deck of Bay Saint Louis Bridge, looking east--.-.-.-.-.-.- 142

3.54 Displaced span of Bay Saint Louis Bridge-.................-. 143

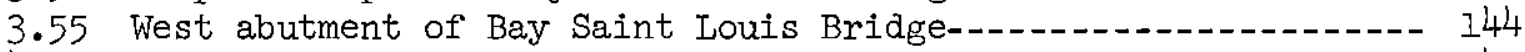

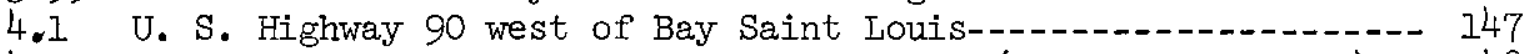

4.2 U. S. 90 near west end of Pass Christian (east-bound lanes)--- 148

4.3 U. S. 90 neax Pass Christian-....... 149

4.4 Aerial view of damaged tung trees near Purvis, Mississippi---- 150 
CONVERSION FACTORS, BRITISH TO METRIC UNITS OF MEASUREMENT

British units of measurement used in this report can be converted to metric units as follows.

\begin{tabular}{lcl}
\hline \multicolumn{1}{c}{ Multiply } & By & \multicolumn{1}{c}{ To Obtain } \\
\hline inches & 25.4 & millimeters \\
feet & 0.3048 & meters \\
pounds (force) per square inch & 6894.757 & newtons per square meter \\
inches of mercury (32 F) & 3386.389 & newtons per square meter \\
miles (U. S. statute) & 1.609344 & kilometers \\
miles (U. S. statute) per hour & 1.609344 & kilometers per hour
\end{tabular}


CHAPTER 1

INTRODUCTION

\subsection{BACKGROUND}

Hurricane Camille, the third tropical Atlantic storm of 1969, struck the United States mainland during the late hours of Sunday, 17 August 1969, coming ashore along the Mississippi Gulf Coast. With winds reportedly approaching or exceeding $200 \mathrm{mph}^{*}$ near the eye of the storm at the time it came aground, it was reported to be the most intense, although not the largest, hurricane ever to hit the United States mainland. There was extensive water and wind damage to the Mississippi Gulf Coast and to the Mississippi River Delta below New Orleans, Louisiana, with considerable wind damage extending along the storm's path inland.

On 20 August, Dr. J. O. Buchanan (Office of Civil Defense, Research) requested that Office, Chief of Engineers (OCE) provide support from the U. S. Army Engineer Waterways Experiment Station (WES) to aid in conducting an OCD-sponsored survey of the storm damage.

\subsection{SCOPE AND PURPOSE}

In a telephone call on $2 l$ August among Mr. W. J. Flathau and LTC F. M. Anklam (WES) and Messrs. F. Heller and R. Stellar (OCE), WES was requested to provide transportation (both air and ground) and professional assistance ". . to aid OCD contract personnel in making an aerial reconnaissance of the disaster area, obtaining representative photographic coverage, and related work. . . " starting on 22 August.

The field party included two professional staff members of the URS Corporation, Burlingame, California: Mr. James F. Halsey, Director, Theoretical and Applied Mechanics; and Dr. Carl F. Miller, Vice- President and Director, Resource Allocations Research Program. WES representatives were Messrs. R. S. Cummins and M. E. Criswell, Research Structural Engineers, and Mr. George Newman, Photographer.

* A table of factors for converting British units of measurement to metric units is presented on page 9. 
The purpose of the survey was as follows:

1. Survey the damage caused by the storm, especially to buildings, utilities, and other life-supporting systems, and the cleanup and recovery operation and organization.

2. Relate these findings to possible damage from a nuclear blast and the postattack recovery and/or suggest research needed to accomplish this.

The WES personnel were particularly concerned with the structural performance of civil engineering structures and other buildings located in the storm-damaged area. Therefore, this report will discuss primarily the damage to structures resulting from Furricane Camille, especially to those along the Mississippi Gulf Coast.

\subsection{INSPECTION TEAM ITINERARY}

1.3.1 22 August. The inspection team left the Vicksburg Airport, Vicksburg, Mississippi, at 7:00 a.m. aboand a chartered, six-passenger aircraft for New Orleans. The team arrived at the New Orleans District (NOD), Corps of Engineers, office at approximately 9:00 a.m. During this visit, MAJ West, Executive Officer, and his staff presented an excellent briefing regarding the damaged areas within the NOD (mainly below New Orleans), and were most helpful in offering their support.

During the afternoon of 22 August, an aerial reconnaissance was made of damage in the Mississippi River Delta area (particularly Plaquemines Parish). Figure 1.I shows the flight path and itinerary.

Turbulent weather moving in from the north and east prevented flight over the Mississippi Gulf Coast area. After stops at Houma and Hammond, Louisiana, due to the unfavorable weather conditions, the party continued the flight to Hattiesburg, Mississippi. In Hattiesburg the party met with other WES personnel who had brought in supplies and ground vehicles from Vicksburg.

1.3.2 23 August. Poor visibility precluded flying on the morning of 23 August; therefore, the party left Hattiesburg by automobile bound for the Gulf Coast.

Personnel of the Office of Emergency Preparedness (OEP) and the U. S. Army Engineer District, Mobile, located in the Operation Center at the 
Gulfport Airport, and the Harrison County OCD Director, Mr. Wade Guice, were contacted and advised of the party's mission.

A brief tour by automobile was made of the storm-damaged area along U. S. Highway 90 from the Gulfport downtown area west to Bay Saint Louis. on the afternoon of 23 August, the party departed the Gulfport Airport for an additional aerial survey of the damaged areas. Unfavorable weather prevented flight east of Gulfport and over Biloxi and Pascagoula, but before returning to Hattiesburg, several Mississippi inland towns (Picayune, Poplarville, Lumberton, and Purvis) along the path of the storm were viewed from the air.

1.3.3 24-25 August. On 24 August, Mr. Halsey and Dr. Miller left the inspection team for a flight to Washington, D. C., to attend a conference at OCD regarding this survey.

The WES personnel returned to the Gulfport area by automobile for closer inspection of selected damaged structures and to make a general damage survey in the Biloxi area, including the Back Bay vicinity.

1.3.4 26 August. On 26 August, WES personnel returned to Vicksburg by automobile. 


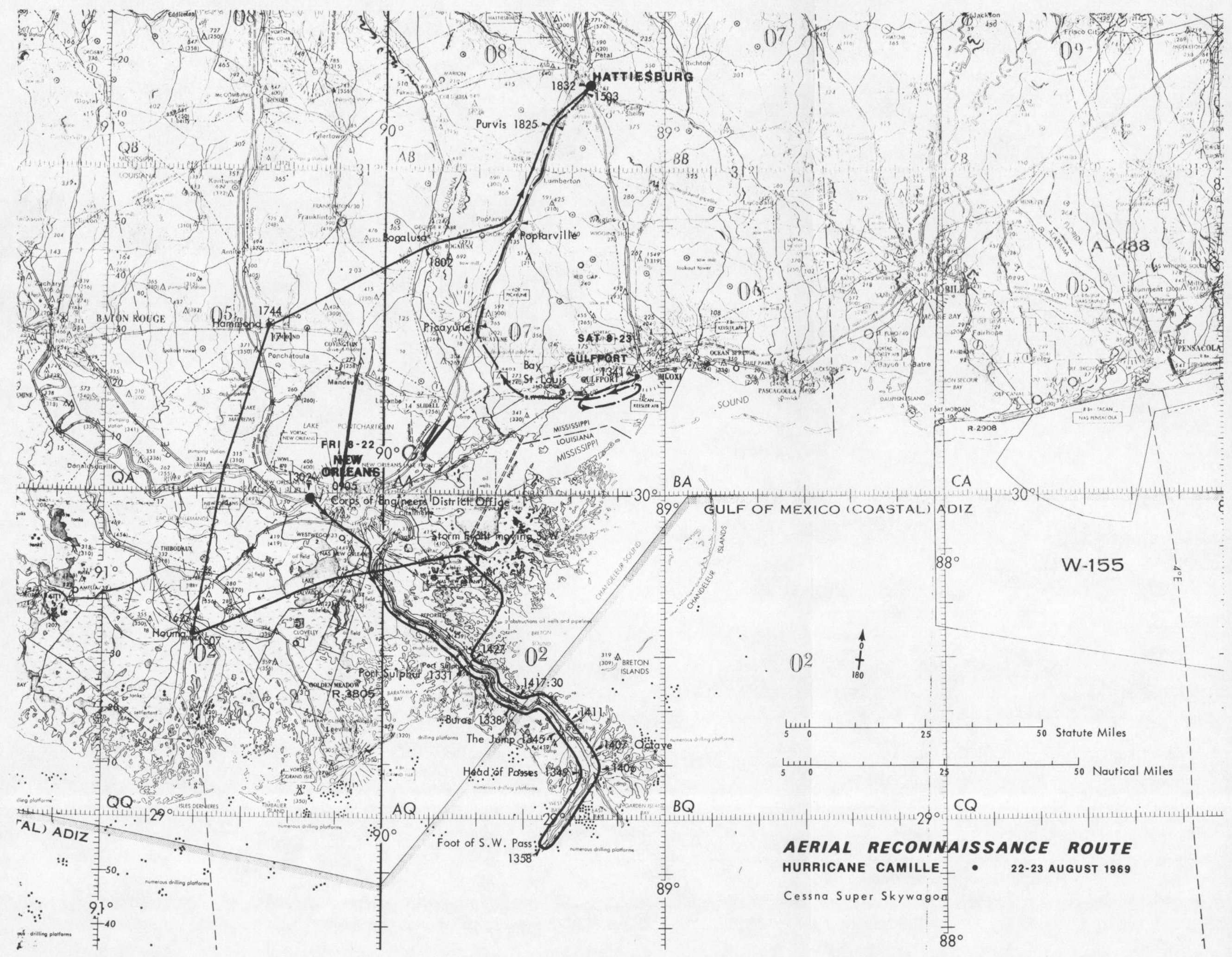

Figure 1.1 Flight itinerary and route. 



\section{CHAPTER 2}

DAMAGE TO STRUCTURES FROM HURRICANE CAMILIE

\subsection{THE STORM}

Camille, spawned as a tropical storm in thé Caribbean sea on 14 August 1969, gained strength rapidly as it touched western Cuba and developed into a very intense storm as it entered the Gulf of Mexico (Reference 1 ). It came ashore about 10:00 p.m. CST on the night of 17 August 1969 along the Gulf Coast of Mississippi, centering its fury in the vicinity of Pass Christian. The highest tides and winds and the lowest barometric pressure ever recorded along the Gulf Coast resulted from Camille. Winds estimated at $190 \mathrm{mph}$ or greater generated 10 to 12 -foot seas atop at least 16-foot tides in many areas. A high-water mark at 24.2 feet above mean sea level was measured east of the Pass Christian business district (Reference 2). Local tornadic winds also were reported in the storm area. Figure 2.1 shows the path and the estimated wind field of Camille (Reference 3). An extremely low barometric pressure of 26.61 inches of mercury was measured in the eye of the storm at 12:15 CST on 17 August, the second lowest pressure ever recorded on or near the United States mainland. A verified pressure reading of 26.85 inches of mercury was measured in the Bay Saint Louis area.

The water level generally changed slowly with continuous wave action rather than one large tidal wave; however, some observers reported localized areas which apparently suffered rapid rise and/or fall of the water level.

As shown in Figure 2.2, the winds from Camille far exceeded the listed 100-year wind intensity of about $110 \mathrm{mph}$ along the Gulf Coast (Reference 4 ).

The storm moved through the coastal area at a speed of about $15 \mathrm{mph}$, traveling in a north by northwesterly direction, passed to the west of Hattiesburg, Mississippi, then turned north and continued through the state. Maximum wind velocity had dropped to $67 \mathrm{mph}$ and a minimum barometric pressure of 28.93 inches was recorded as the storm passed to the east of Jackson, Mississippi. Moderate to heavy rains accompanied 
the storm as it passed through the state.

Camille, reduced to a low-pressure depression in northern Mississippi, moved northward through Tennessee and into Kentucky, then turned eastward (Figure 2.3). Camille continued to vent its fury in the form of torrential rains in Virginia and West Virginia, causing disastrous local flooding and numerous deaths in the area near the James River.

\subsection{GENERAL DESCRIPTION OF STORM DAMAGE}

The most intense damage from Camille was in Plaquemines Parish, Louisiana (below New Orleans), and in the first several blocks inland along the Mississippi Gulf Coast. It appeared that damage in these areas resulted primarily from high water and wind-driven wave action. Structures were completely leveled along some of the coastal areas.

Flooding without the destructive pounding from wave action and water movement was evident in many low areas several blocks inland, particularly in the east end of Biloxi, which was afforded protection by the proximity of Deer Island.

Wind damage along the coast, though certainly not negligible, was generally secondary to the damage from water and water movement. The wind damage in inland areas was generally less than this inspection team had expected. The 190-mph winds reported correspond to a dynamic wind load of approximately $0.85 \mathrm{psi}$. Most of the structures, however, were not subjected to winds of this magnitude because trees, adjoining structures, and other objects causing ground drag prevented their being loaded with the maximum wind load. Also, the wind velocity was less in areas away from the storm center and the winds dissipated considerably as Camille moved inland (see Figure 2.1).

Although less than one week elapsed from the time of the storm until this inspection trip, much debris had already been cleared from highways and streets, plywood had been removed from most windows, and much broken glass had been replaced. Some evidence of these operations can be seen in the photographs contained herein.

2.2.1 Mississippi River Delta, Louisiana. Damage observed from the air appeared to have been caused almost entirely by high water and wave 
action driven across the delta marshland from an easterly direction over the Mississippi River levees. Many areas were still flooded at the time of this inspection trip.

The damage was greatest from Empire to Venice, an area where only a narrow strip of low-lying marshland separated the communities along the Mississippi River from Breton Sound, a part of the Gulf of Mexico, to the northeast. Figure 2.4 is a map of this area.

Many mobile homes (brought in after Hurricane Betsy in 1965) and small houses in this area were completely destroyed. In numerous cases, these structures were floated fairly intact onto or past the back levee located behind the river towns. Both the front and back levees were damaged, especially between Buras and Venice. Figures 2.5 through 2.9 are photographs taken by the survey team in the Empire-Buras area. Figures 2.10 through 2.13 are photographs taken on 19-20 August 1969 by personnel of the New Orleans District, Corps of Engineers (NOD).

Most of the structures in this area were either light single-family dwellings or heavy industrial (oil, sulphur, shipping) construction. From the air, the industrial construction usually appeared to have remained structurally intact.

2.2.2 Mississippi Gulf Coast. A large portion of, and the most impressive, storm damage paralleled the Mississippi Gulf Coast and extended from one to several blocks inland, depending on the local topography. This damage it would seem resulted primarily from rising water and wave action.

The wind directions in the Gulf Coast area changed continually as Camille with its counterclockwise winds moved northward. The maximum winds in the Gulfport area appeared to have been from the east. The tidal rise and wave action apparently came from the south to southeast.

A map of the central Mississippi Gulf Coast area is shown in Figure 2.14. The most heavily damaged areas visited by this team included the Pass Christian vicinity, parts of Long Beach, and local waterfront areas between the Biloxi and Gulfport business districts. Aerial views of the area from Gulfport west are contained in Figures 2.15 through 2.27. Figures 2.25 through 2.27 were taken on 19 August 1969 by NOD. The coastal 
area immediately north and west of the Port of Gulfport was somewhat sheltered by the port facilities.

All of the coastal area along U. S. Highway 90 from Saint Louis Bay to Biloxi Bay, a distance of 27 miles, was built up with a variety of construction types including many large, old residences and several multistory resort hotels, motels, and apartments, as well as gasoline stations, restaurants, and retail stores.

Many motels and apartments were completely leveled. Many older and multistory houses remained standing, even though they sustained extensive structural damage at the first floor level primarily from the effects of high water and the pounding of waves. In many cases, the contents of the first floor were washed out. A large portion of the heavily damaged structures, especially the older residences, that remained standing will probably be torn down as restoration will be either impossible or uneconomical.

Numerous trees were down in the coastal area. Bark was off the seaward side of many trees 12 to 15 feet from the ground, indicating the upper level of wave action and effects of waterborne debris.

The extent of debris deposited inland marked the limit of greatest tidal action. The debris line is clearly seen in Figure 2.17.

Many small boats and several barges and storage tanks floated ashore, some leaving considerable structural damage in their path. Large rolls of kraft paper and bales of jute came inland from the Port of Gulfport facilities. Three large freighters were floated aground in the Port facilities. The downtown area of Gulfport and inland coastal areas had only comparatively small amounts of structural damage. In the downtown area of Gulfport, some windows and signs were broken and many first floor areas suffered water damage. The post office, only one block from the coastal highway (U. S. 90), appeared undamaged except for water in the partial basement, the location of a NFSS Fallout Shelter. In other areas of Gulfport, some lightly constructed buildings and roofs were blown over with window breakage and roof damage quite common. Isolated pockets of residences inland were heavily damaged, with some homes leveled, probably by local tornadic winds.

Water damage along the Back Bay of Biloxi was less than that along the 
coast, probably because it was protected from the pounding wave action, but flooding was still very severe.

Some general damage photographs of the Mississippi coastal region are contained in Figures 2.28 through 2.39.

2.2.3 Inland Areas. The main inland damage visible from the air was to trees, light utility buildings, house trailers, and roofs, especially corrugated metal roofs.

In the path of the storm, some larger buildings, especially school gymnasiums and long-span steel frame buildings, were damaged. A considerable portion of the structural damage to residences was caused by falling trees.

\subsection{PERFORMANCE OF STRUCTURAL TYPES}

Some types of structures withstood the wind and water forces much better than others. Failure modes of various structural types also varied considerably.

Survival of the structures was primarily governed by the ability of the building to resist lateral loads and the care taken with the design and construction details.

Specific case studies will be discussed in Chapter 3 .

2.3.1 Masonry Block Structures. Many motels, apartments, gasoline stations, and small businesses along the Gulf shoreline were constructed of block and/or brick bearing walls, and these structures generally fared very poorly. An appreciable number collapsed totally with little evidence remaining to indicate how they looked before the storm. Almost all buildings of this type were totally destroyed in the area along the coast from Gulfport to Bay Saint Louis. Figures 2.40 through 2.46 show the remains of some buildings of this type.

Masonry block buildings were usually either totally destroyed or left relatively unharmed, a behavior expected because of the brittle nature of nonreinforced or very lightly reinforced block walls. A few block buildings had only the south or east portions destroyed.

Block walls are inherently weak in resisting tension or bending, loading cases necessarily accompanying the water and wind movement. Block 
buildings have little "give" or ductility. Many block buildings along the Gulf Coast probably failed when the walls were destroyed and the rest of the structure, being inadequately supported, collapsed and came apart like a house of dominoes. The debris from the block buildings was usually of fairly small size, many individual blocks and pieces having a largest dimension of 4 feet or less.

Figure 2.43 shows the remains of the Richelieu Apartments, where 23 people died after ignoring repeated warnings by local authorities to vacate the building.

Block buildings inland generally suffered little damage except where very slender walls were used.

2.3.2 Wooden Frame Buildings. Many two- and three-story older frame residences lined the coast, especially west of Long Beach and between Gulfport and Biloxi. Many withstood the storm forces amazingly well. Depending on the location, many were totally leveled or destroyed (Figures 2.47 and 2.48), but others remained standing even after very extensive structural damage to the first floor area (Figure 2.49). Survival in the top floors of many older wooden frame buildings would have been possible in many cases when so-called modern buildings in the area were totally destroyed.

These older buildings were tied together much better than the masonry structures, functioned much more as a unit, and were much less dependent on deadweight for their stability. Well constructed wooden buildings are generally very ductile in behavior; they can withstand large movements before collapsing. Also, the diagonal sheeting on the exterior and the numerous interior walls capable of functioning as shear walls and loadbearing walls helped these buildings withstand the lateral loads produced by the storm.

Many wooden frame structures, especially older residences, were not designed by analysis but were built based on experience and intuition to have "sufficient strength" using convenient and available material sizes. If these buildings were structurally analyzed, many no doubt would be found to have very high factors of safety for normal design loads. These nondesigned (from an analysis standpoint) wooden structures probably ranged from 
the most underdesigned to the most overdesigned structures in the area.

Along the Gulf Coast and especially in the Mississippi River Delta, many wooden buildings were lifted from their foundations and transported relatively intact by the water for appreciable distances.

The behavior of wooden frame structures inland, those receiving only wind loading, varied considerably. Most withstood the wind loads fairly well. Those damaged were usually very lightly constructed (such as utility buildings), deteriorated, or inherently weak, and often had relatively large wall-free interiors (e.g. stores, garages, and farm buildings).

2.3.3 Iight Steel or Concrete Frame Buildings. A considerable number of single-story stores, warehouses, and shops were located along the coast which were constructed with steel frames, nonstructural masonry or sheet metal exterior walls, small roof beams or bar joists, and built-up roofing. Along the coastline, the walls of most of these buildings failed before the frame itself, and the contents of the building were washed out. The bare frame was often left, sometimes with the steel columns noticeably out of plumb. Figure 2.50 shows a steel frame building in Gulfport. Some frames and portions of the roofs collapsed when bar joists supporting the roofs were not adequately connected at their ends.

Figures 2.51 and 2.52 show two gutted frame structures, and another such structure will be discussed in Chapter 3 .

Small concrete frame buildings were not numerous. The walls and roofs usually failed before the frame. Figure 2.53 shows one such building. Inland, the wind damage to these structures was primarily limited to window breakage, and damage to some sheet metal walls and to roofs.

2.3.4 Heavier Business and Mutistory Construction. The heavier frame and masonry structures, such as the multistory hotels and structures in the downtown areas of Biloxi and Gulfport, usually sustained only superficial structural damage, i.e. damage to windows, signs, awnings, nonstructural exterior walls and screens, and water damage in basements and at first floor levels. A view of Gulfport from the south is shown in Figure 2.54.

One of the few newer tall buildings in the area was the eight-story concrete frame building of the Mississippi Power Company. It is located 
immediately inland from U. S. Highway 90 in Gulfport and is visible in the background of Figure 3.28. This building had double-glazed windows of large size and sat on an elevated plaza. The only damage was a few broken window panes and damage to the east side of the screen around the penthouse and cooling tower.

In no cases seen did large multistory buildings suffer from overall lateral instability or overturning. Several older hotels and a bank building were up to eight or nine floors high. Many of these buildings have "nonstructural" interior partitions and walls which acted efficiently to help resist lateral loadings.

2.3.5 Buildings with Large Interior Areas: Schools, Churches, and Gymnasiums. Most churches and schools in the Biloxi-Gulfport area suffered only comparatively minor damage. This was not a common type of building along the immediate coastal regions. The front of one fairly large, heavy, wooden frame church located immediately along the coast in Long Beach (Saint Thomas Catholic Church) was destroyed, probably by wave action. Inland, some wind damage to churches and schools was observed. In several cases, the wind force had been sufficient to blow in the tall masonry walls and/or the roofs at the east ends of church naves and gymnasiums.

The Poplarville High School was heavily damaged (see Figure 2.55).

2.3.6 Marine Structures and Bridges. Nearly all piers and boat docks along the Gulf Coast were totally destroyed. The piling, which was often tilted toward land, was all that remained of most of the piers. Figure 2.56 shows part of the Pass Christian Yacht Club facility after the storm. No significant damage to the seawall extending from Bay Saint Louis to Biloxi Bay was seen by this team.

Levees were breached and washed out in several locations along the Mississippi River below New Orleans.

All bridges observed had sustained some damage but none had collapsed. The D'Tberville Bridge north of Biloxi on Back Bay sustained damage when free-floating barges struck it. The railroad bridge over Saint Louis Bay, a multispan causeway, had the rails and ties stripped from it by high water and wave action. The Bay Saint Louis highway bridge had extensive damage to the deck and will be discussed in detail in Chapter 3. 


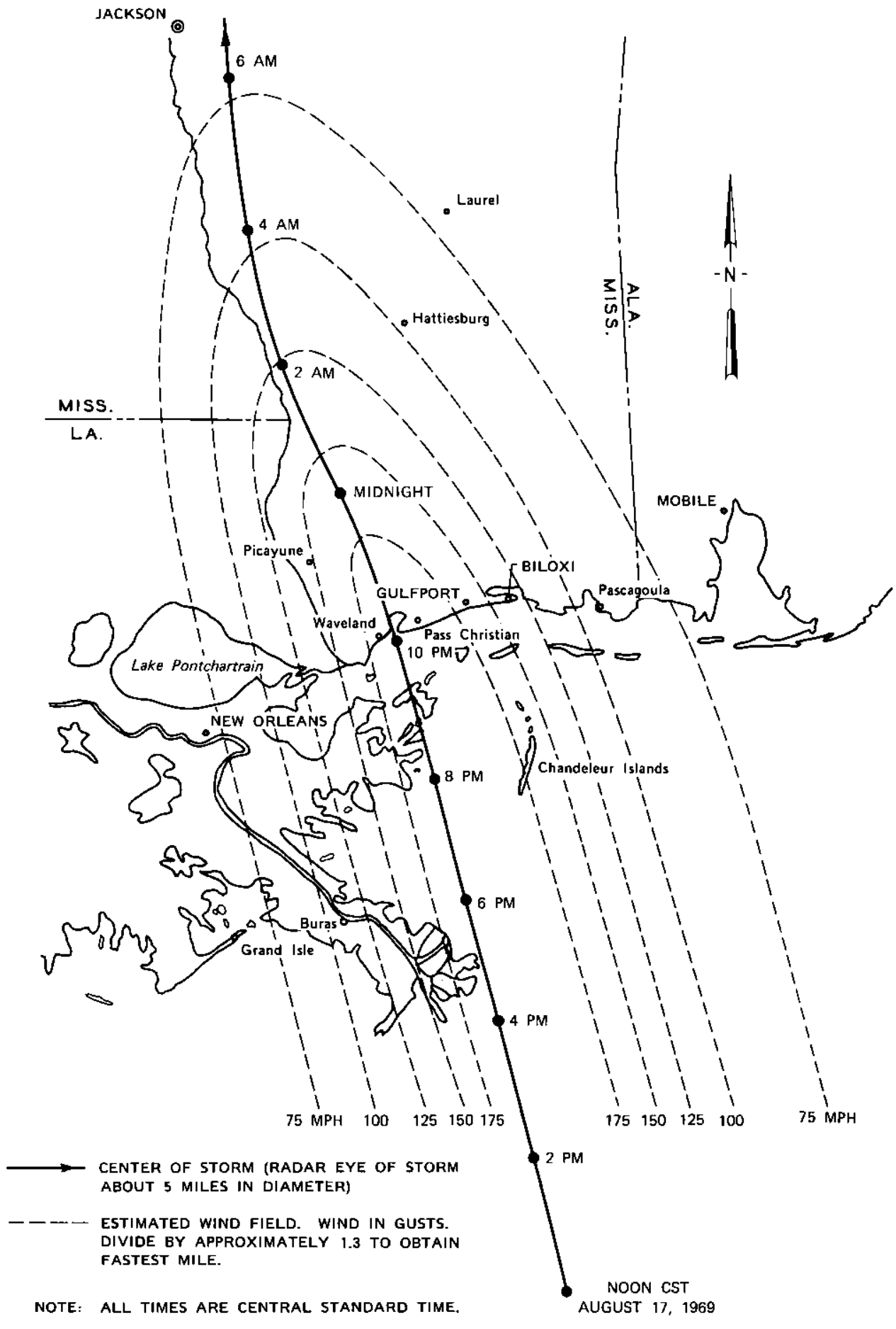

Figure 2.1 Hurricane Camille's path and winds (from New Orleans Weather Bureau). 


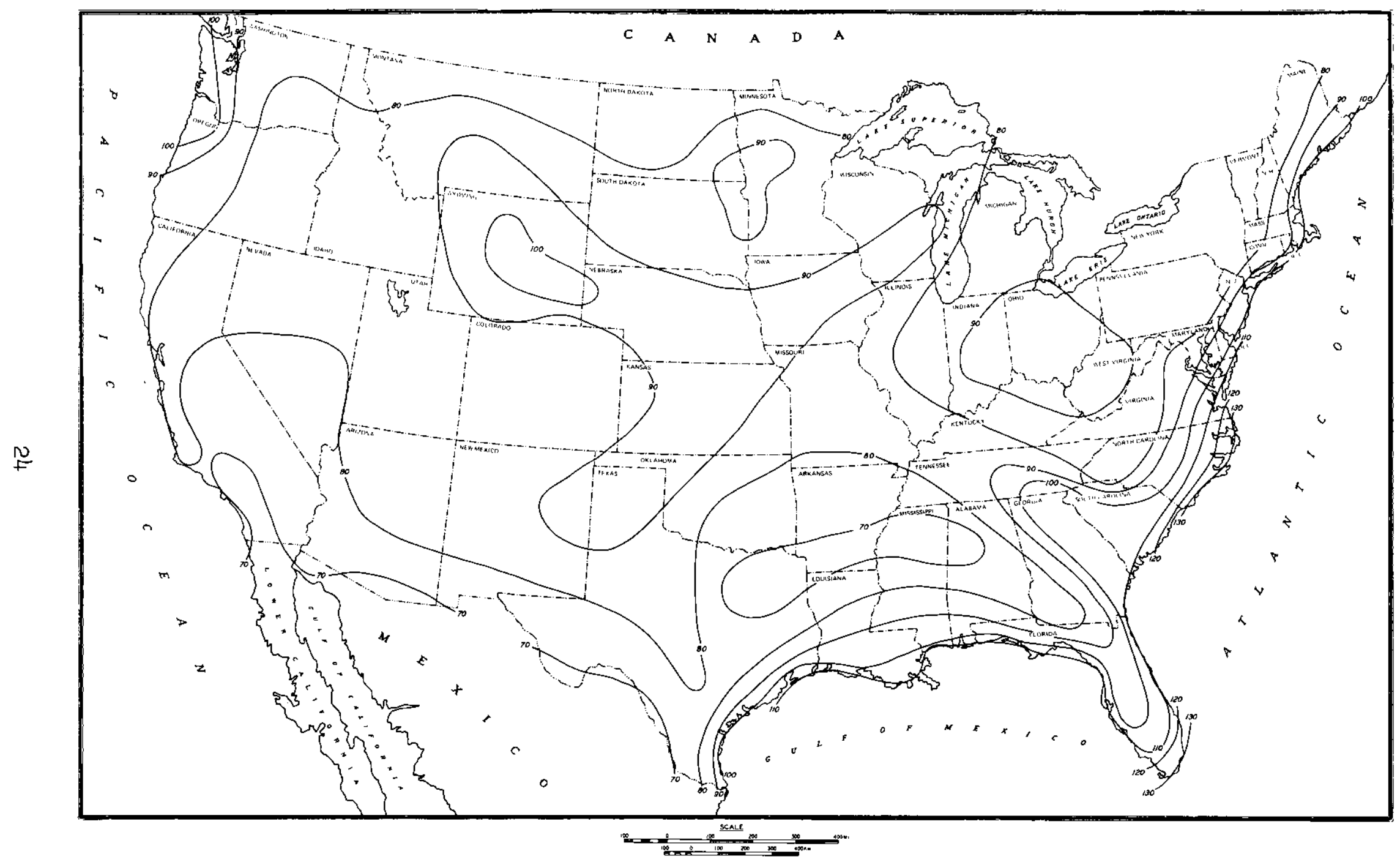

Figure 2.2 Fastest winds, miles per hour, 100-year period of recurrence. 


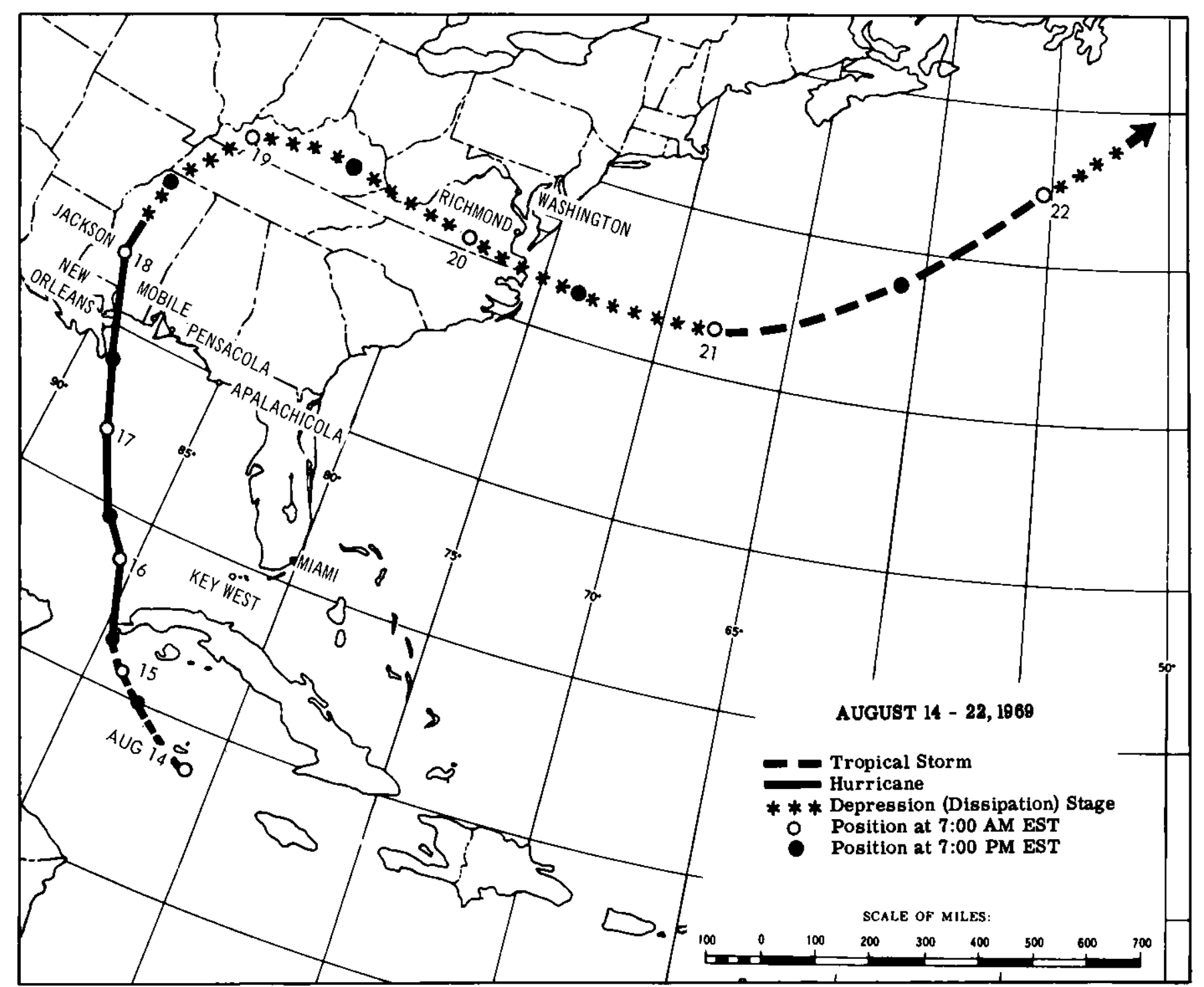

Figure 2.3 Path of Hurricane Camille. 



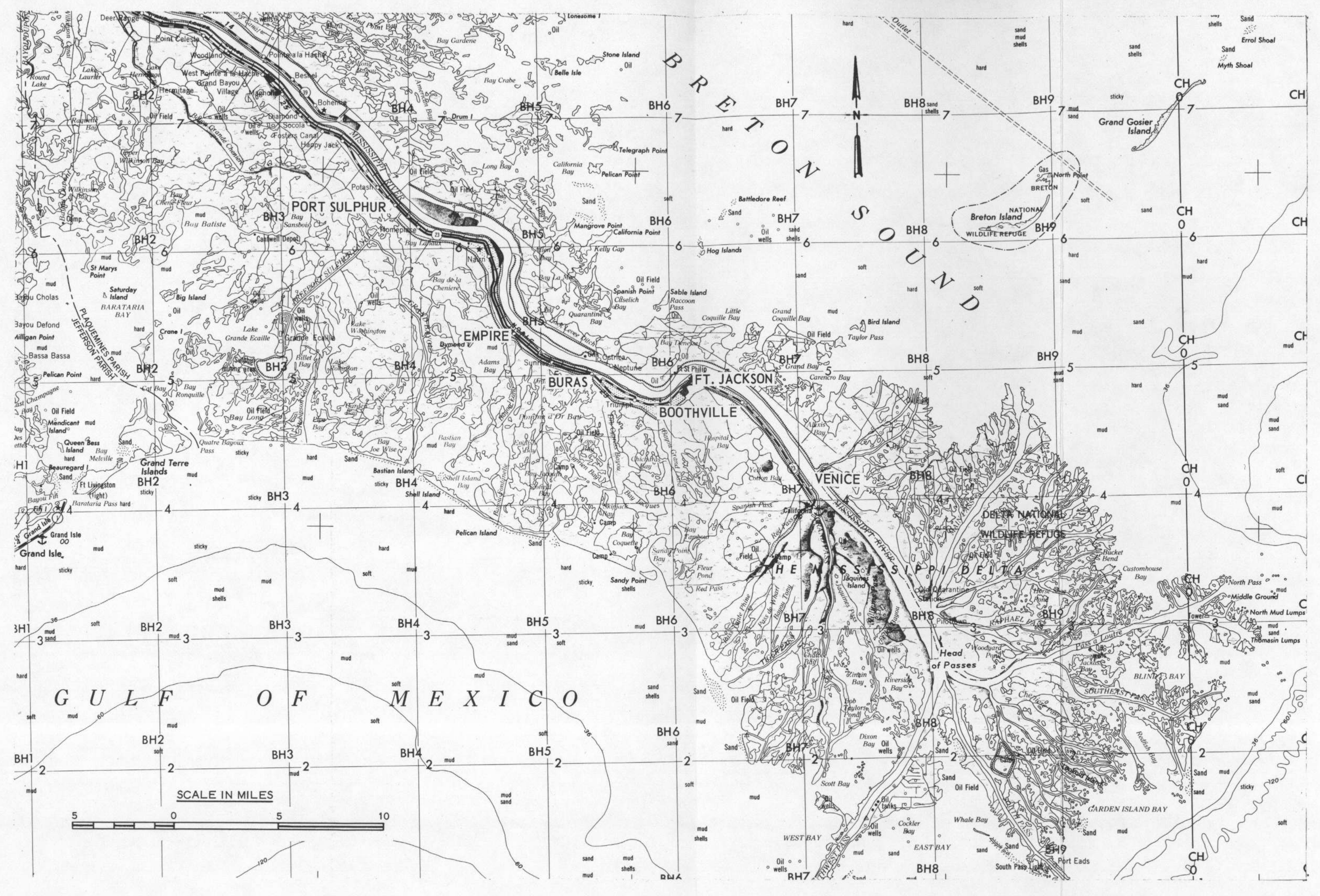

Figure 2.4 Lower Mississippi River delta area 



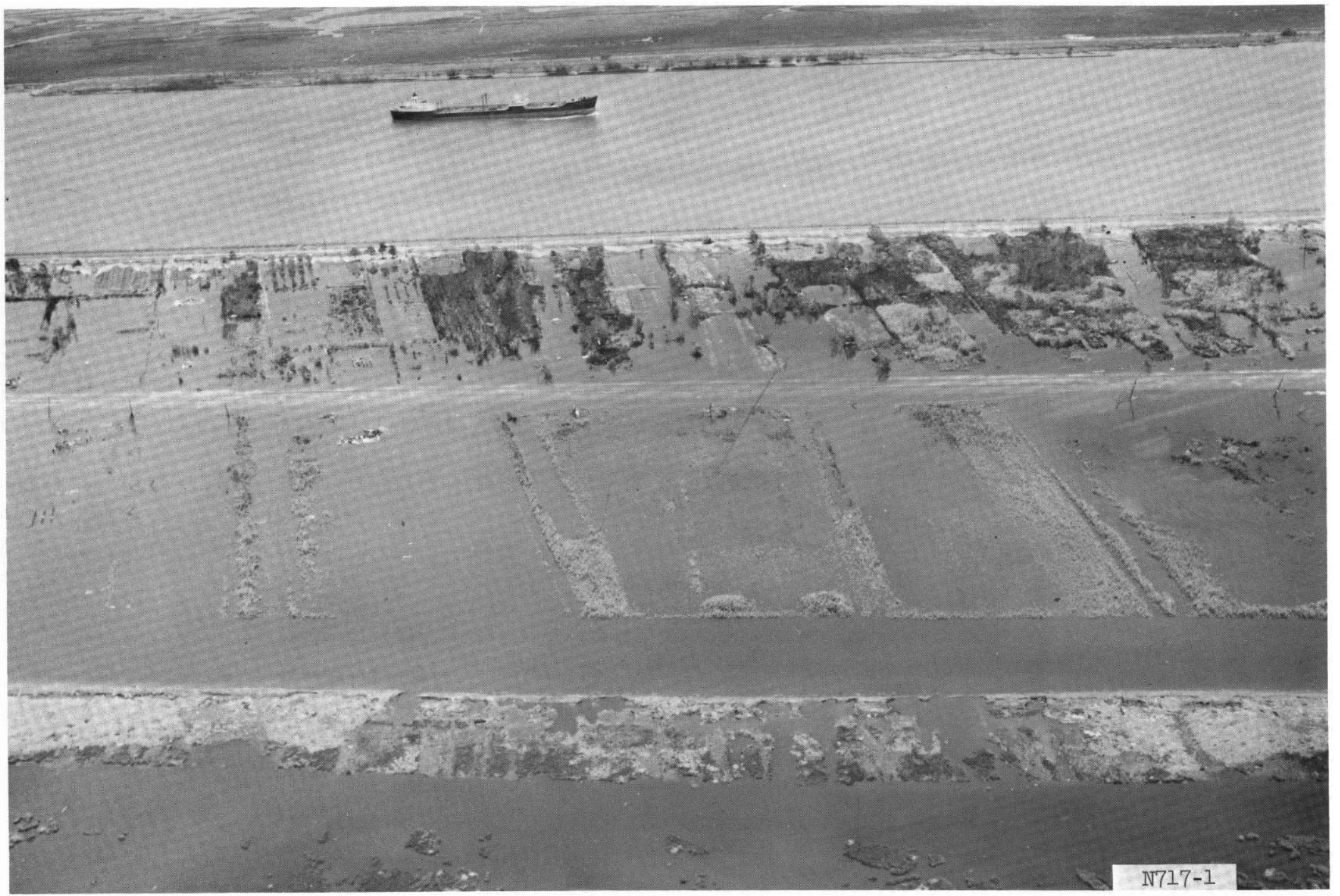

Figure 2.5 Damage near Buras, Louisiana. 


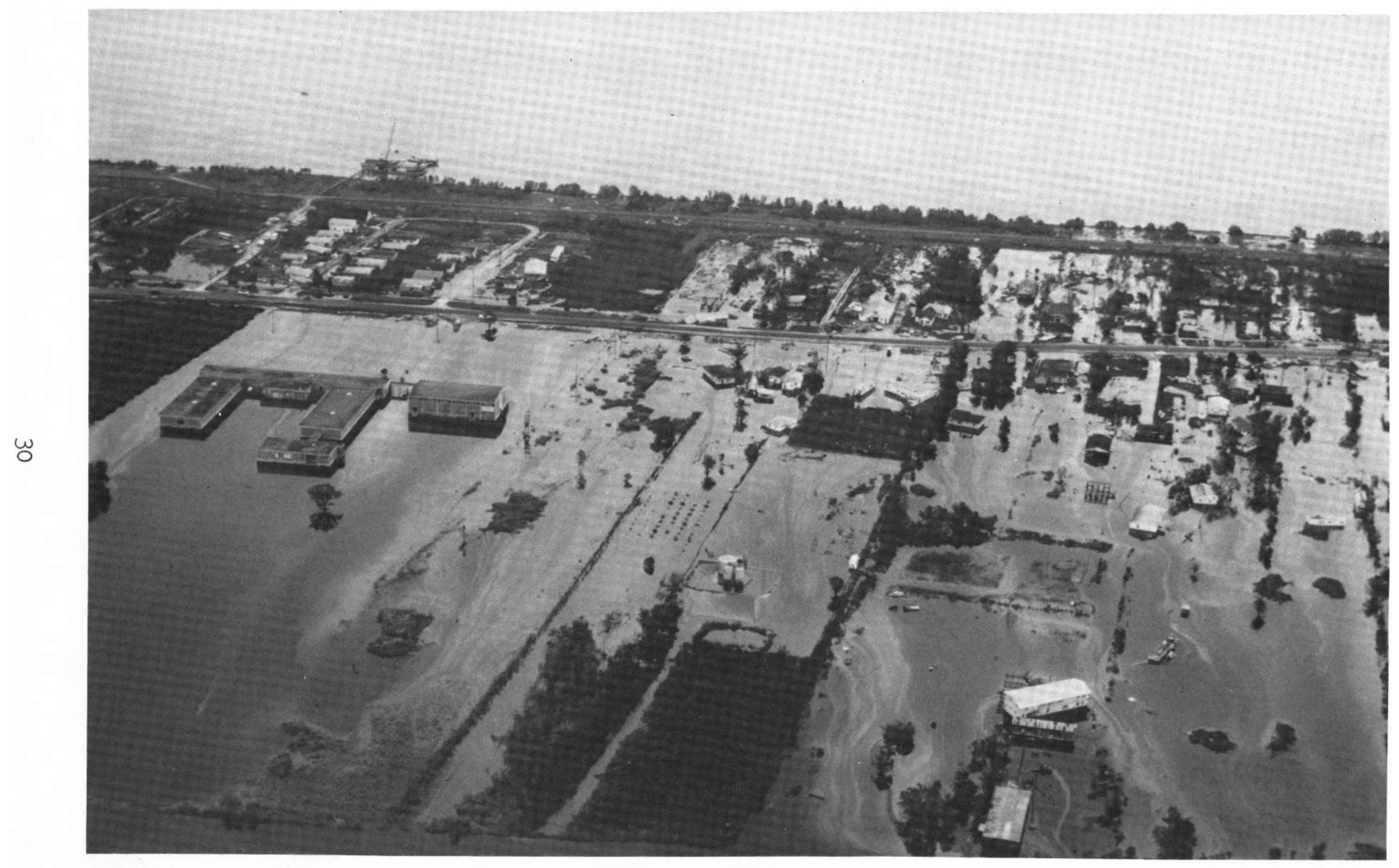

Figure 2.6 South side of Empire, Louisiana. 


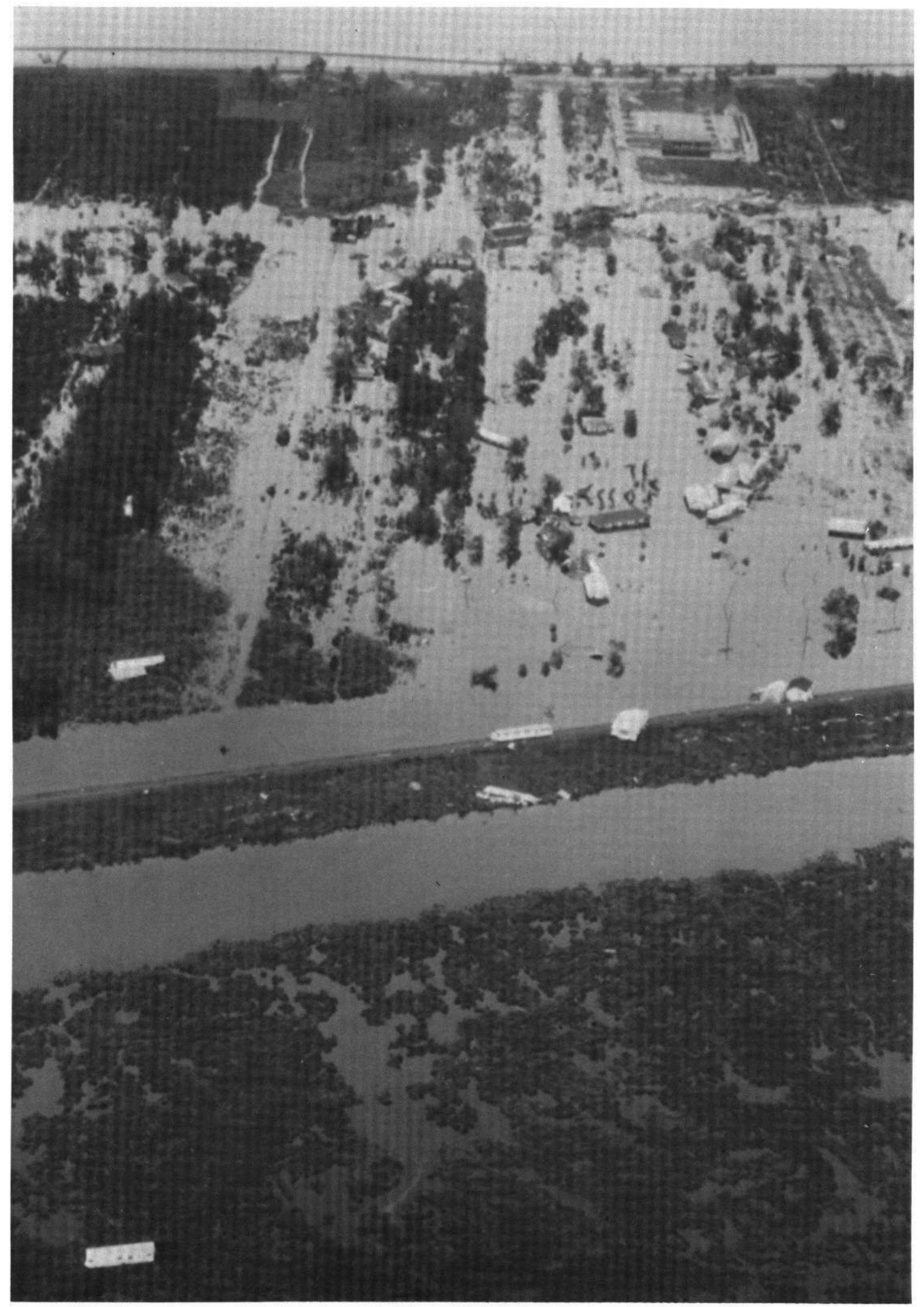

Figure 2.7 Between Empire and Buras, Louisiana. 


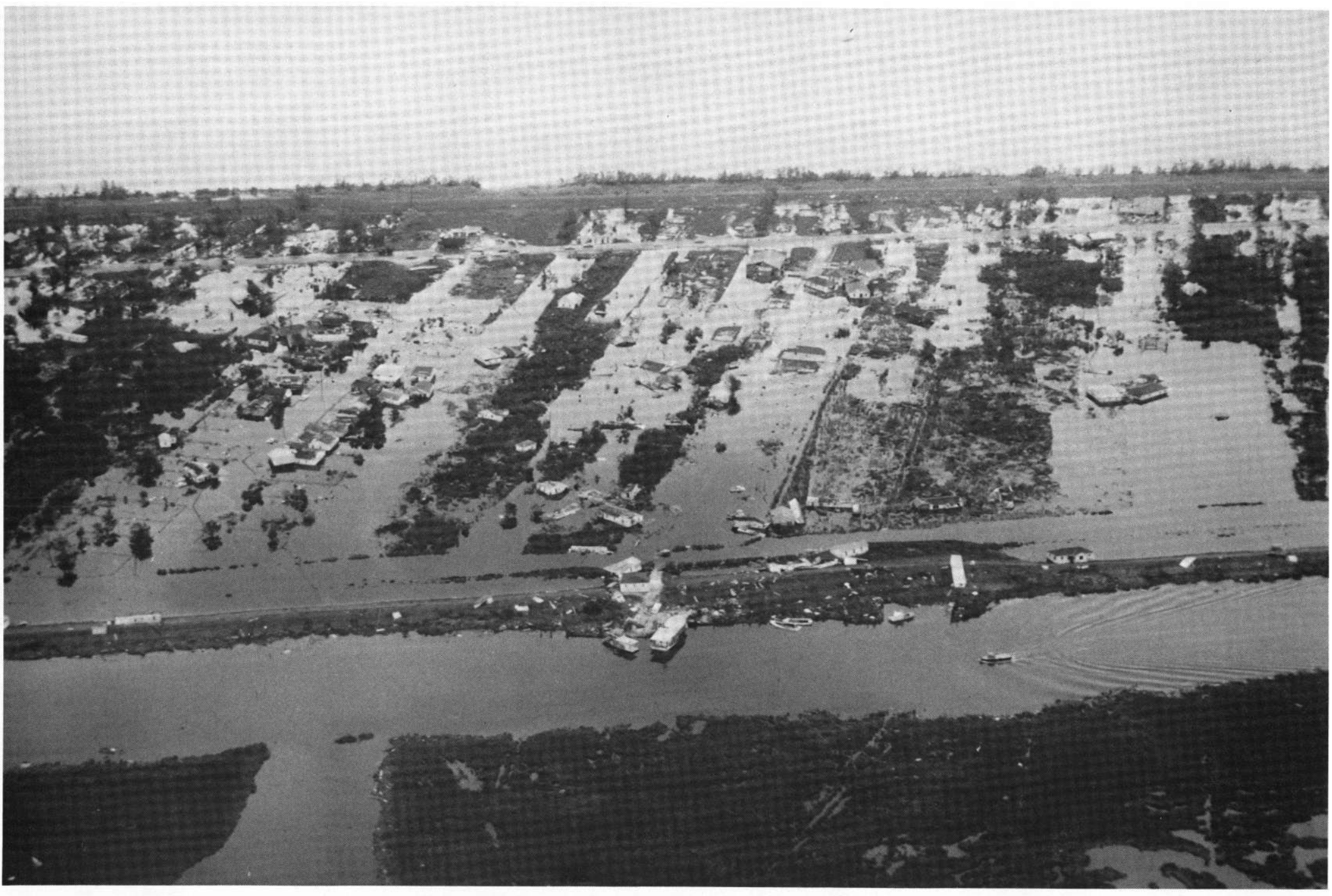

Figure 2.8 Near Buras, Louisiana. 


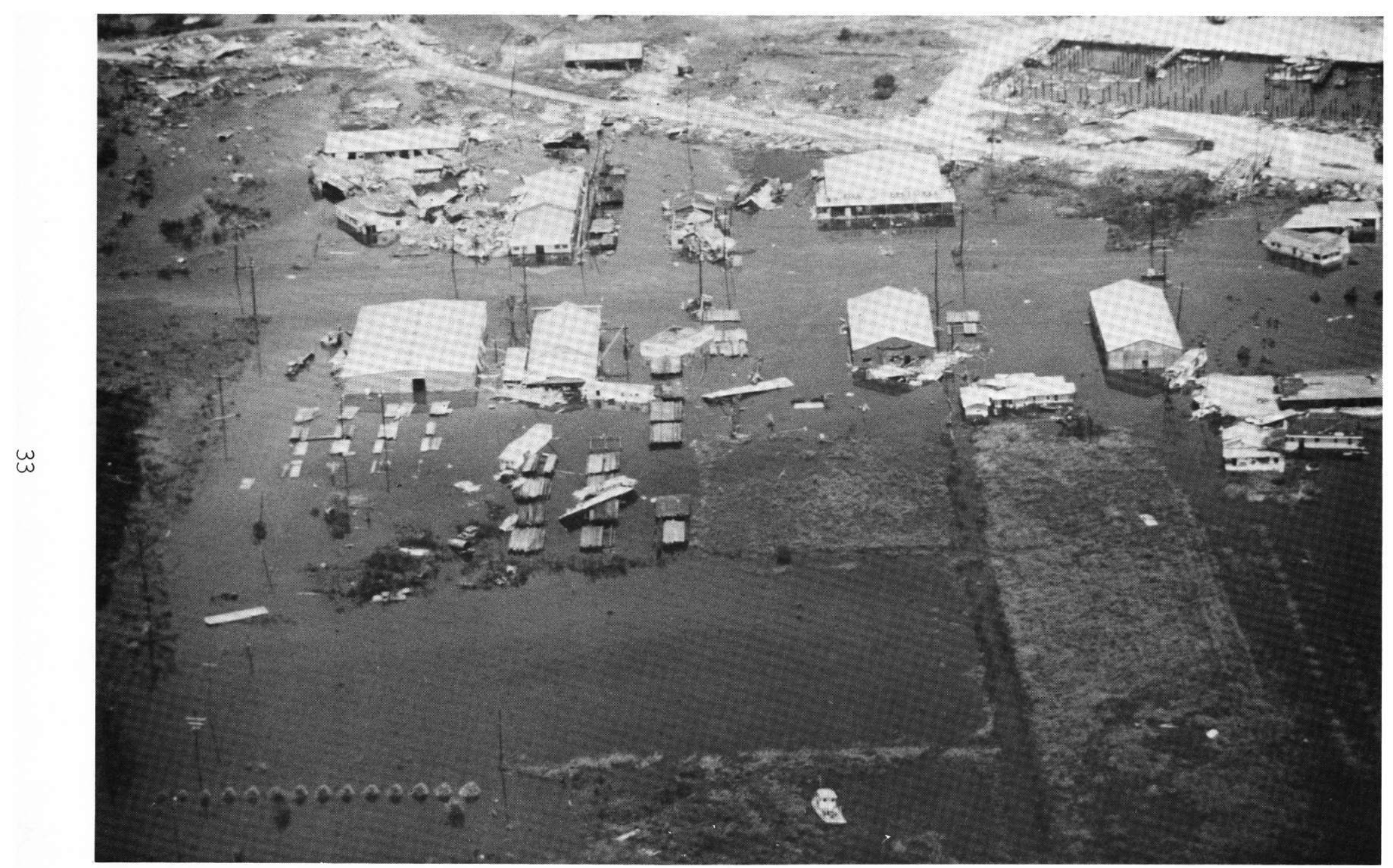

Figure 2.9 Buras area in Louisiana. 


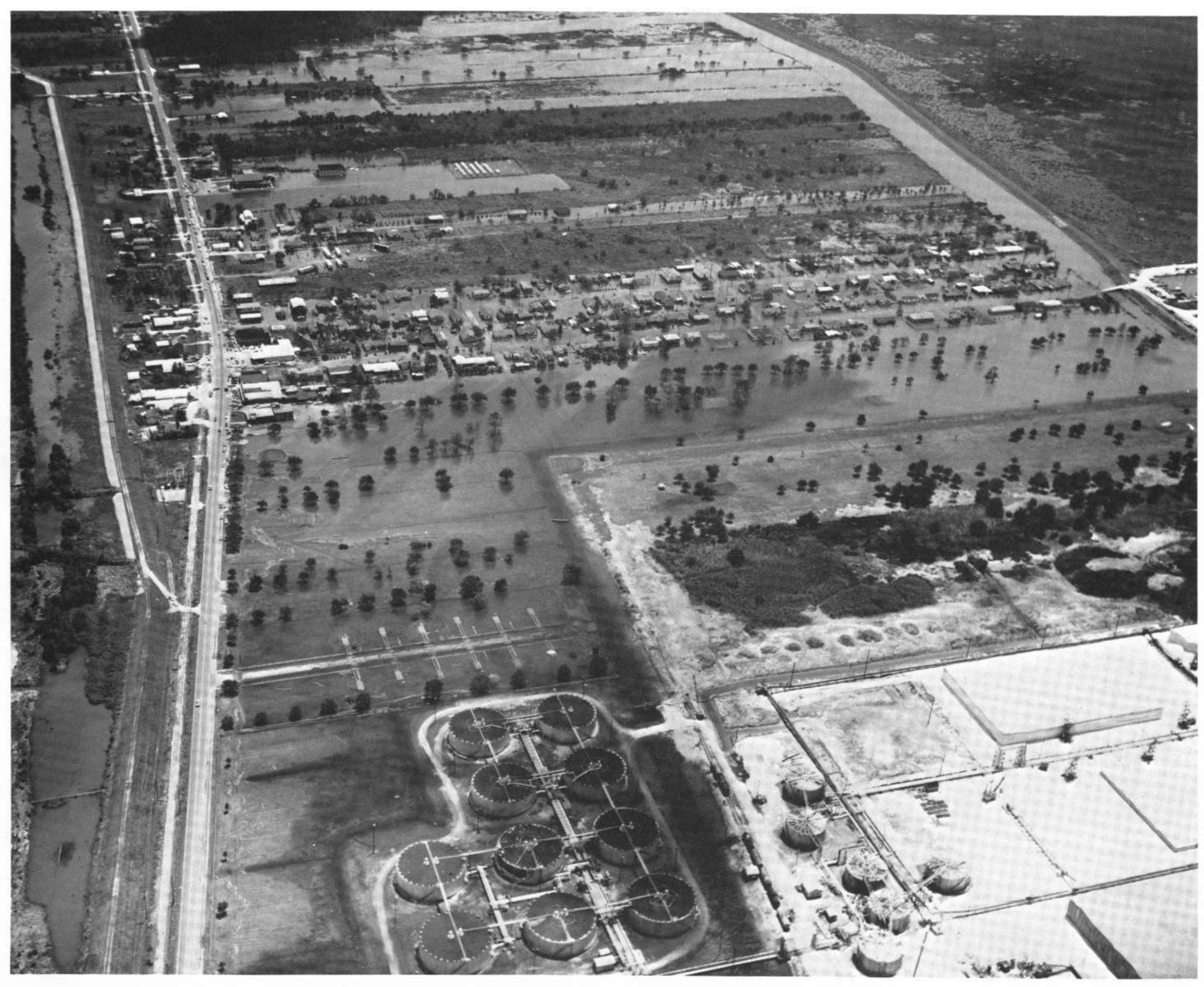

Figure 2.10 Home Place and Port Sulphur, Louisiana. 


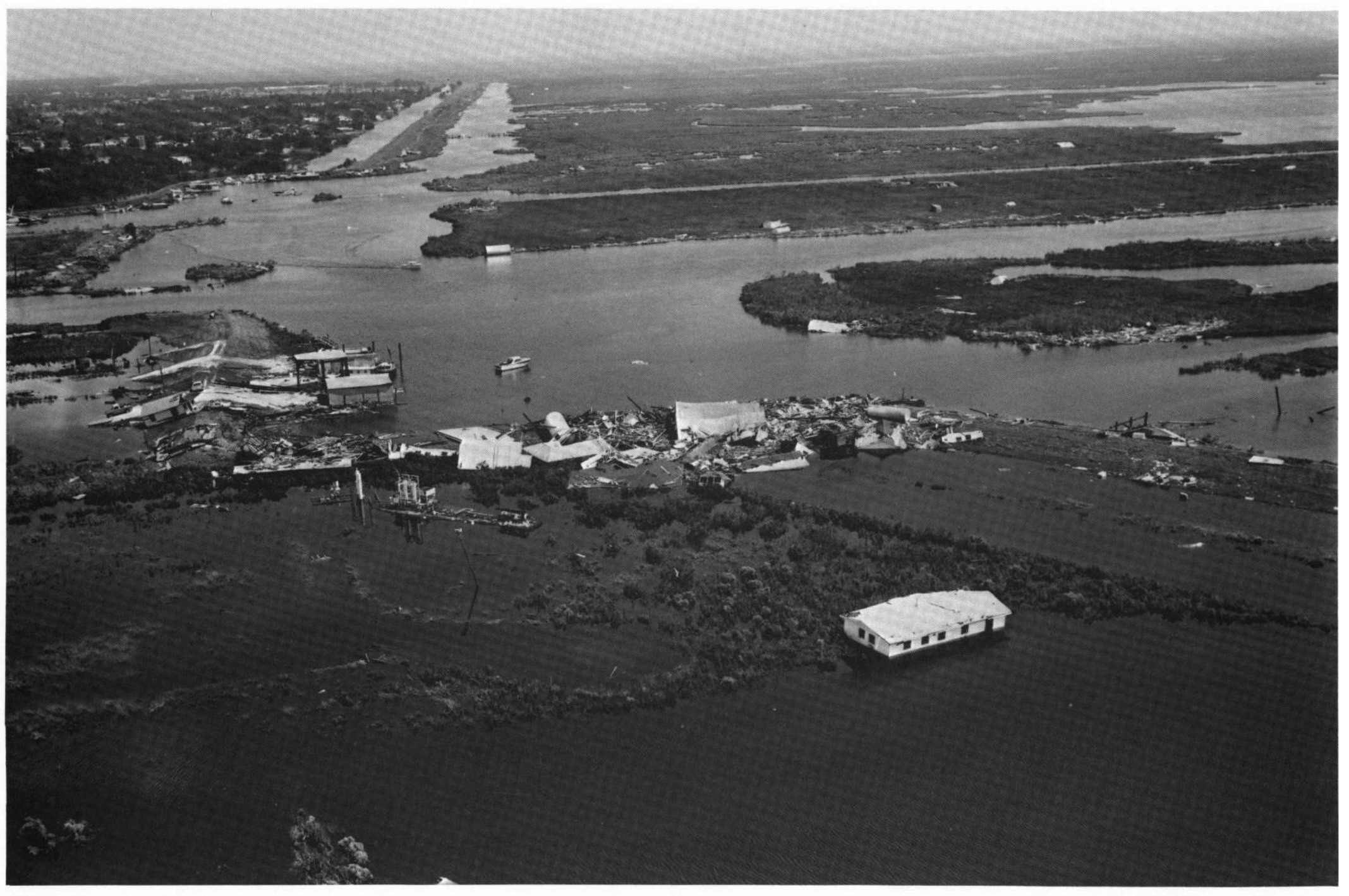

Figure 2.11 Back levee, near Buras, Louisiana. 


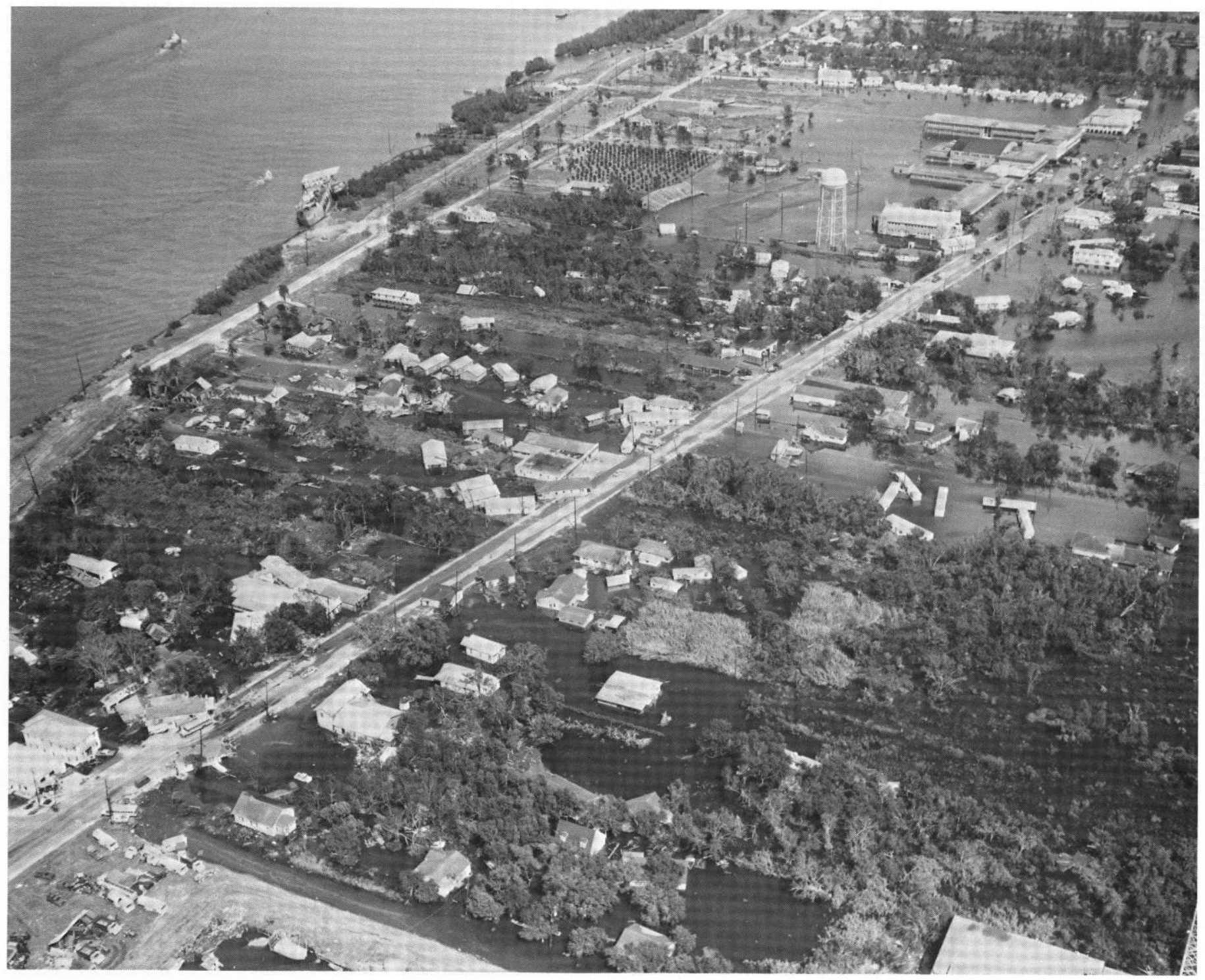

Figure 2.12 Buras, Louisiana. 


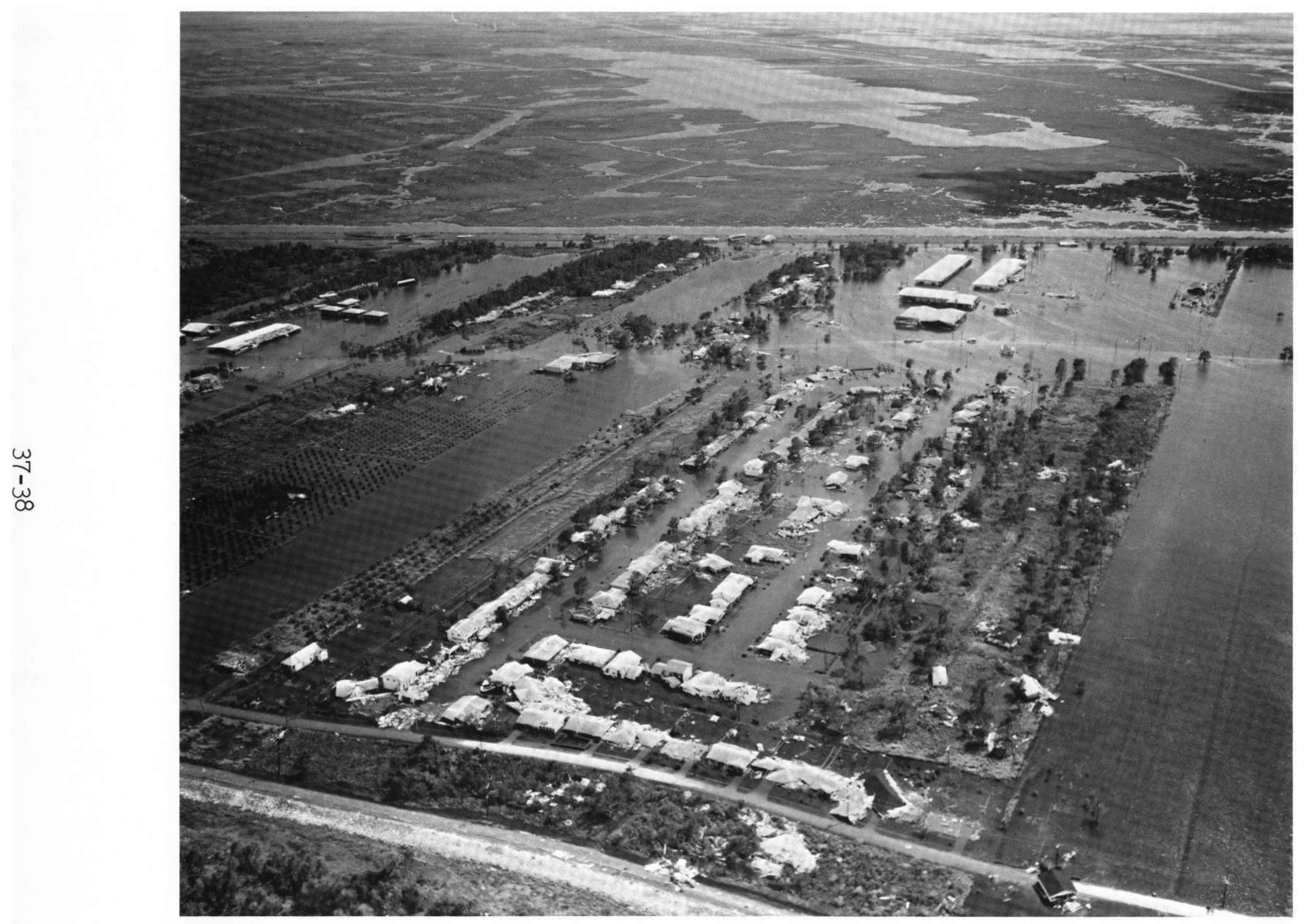

Figure 2.13 Below Buras, Louisiana. 



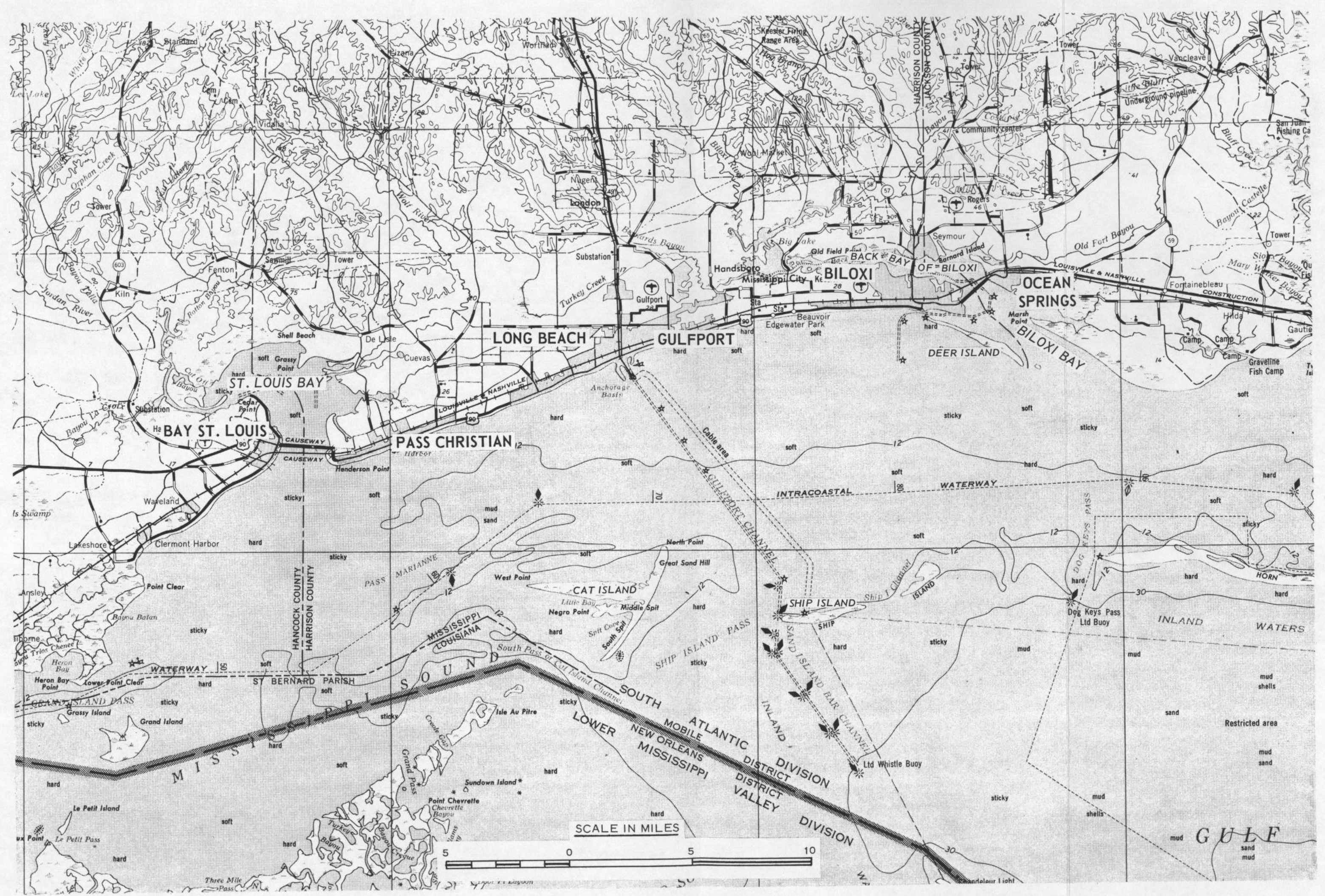

Figure 2.14 Mississippi Gulf Coast 



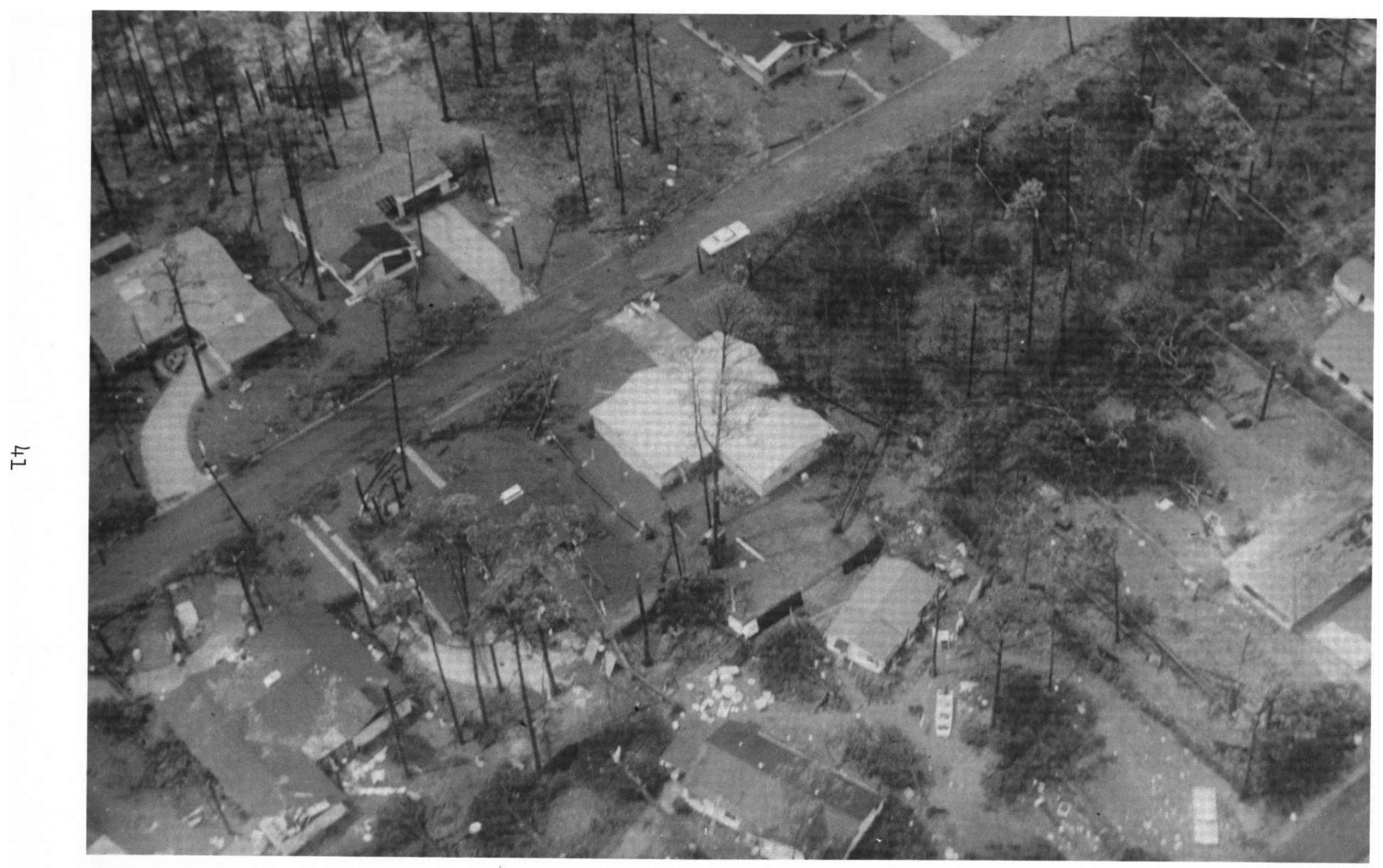

Figure 2.15 Residential area in west Gulfport, Mississippi. 


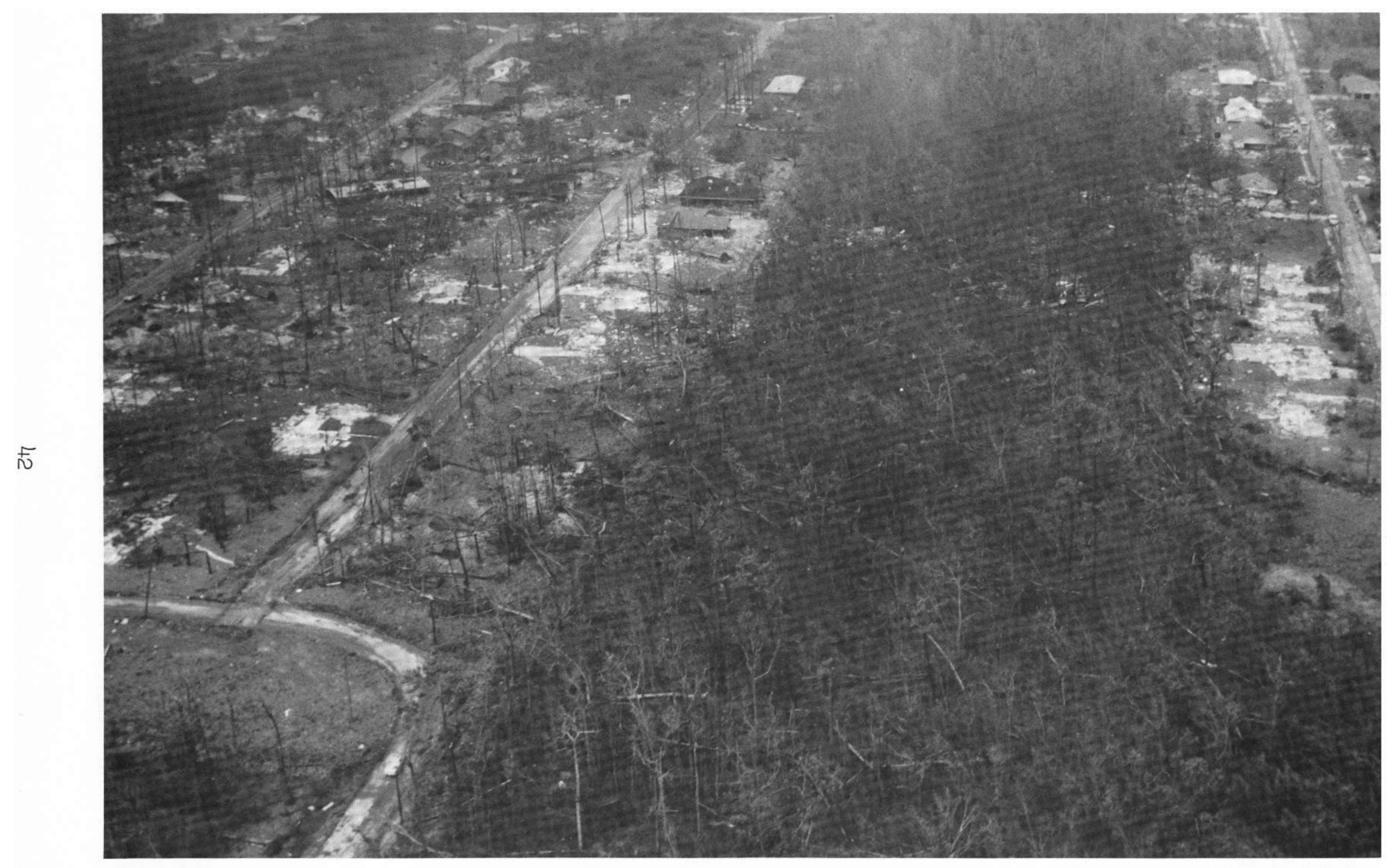

Figure 2.16 Residential district in west Gulfport, Mississippi. 


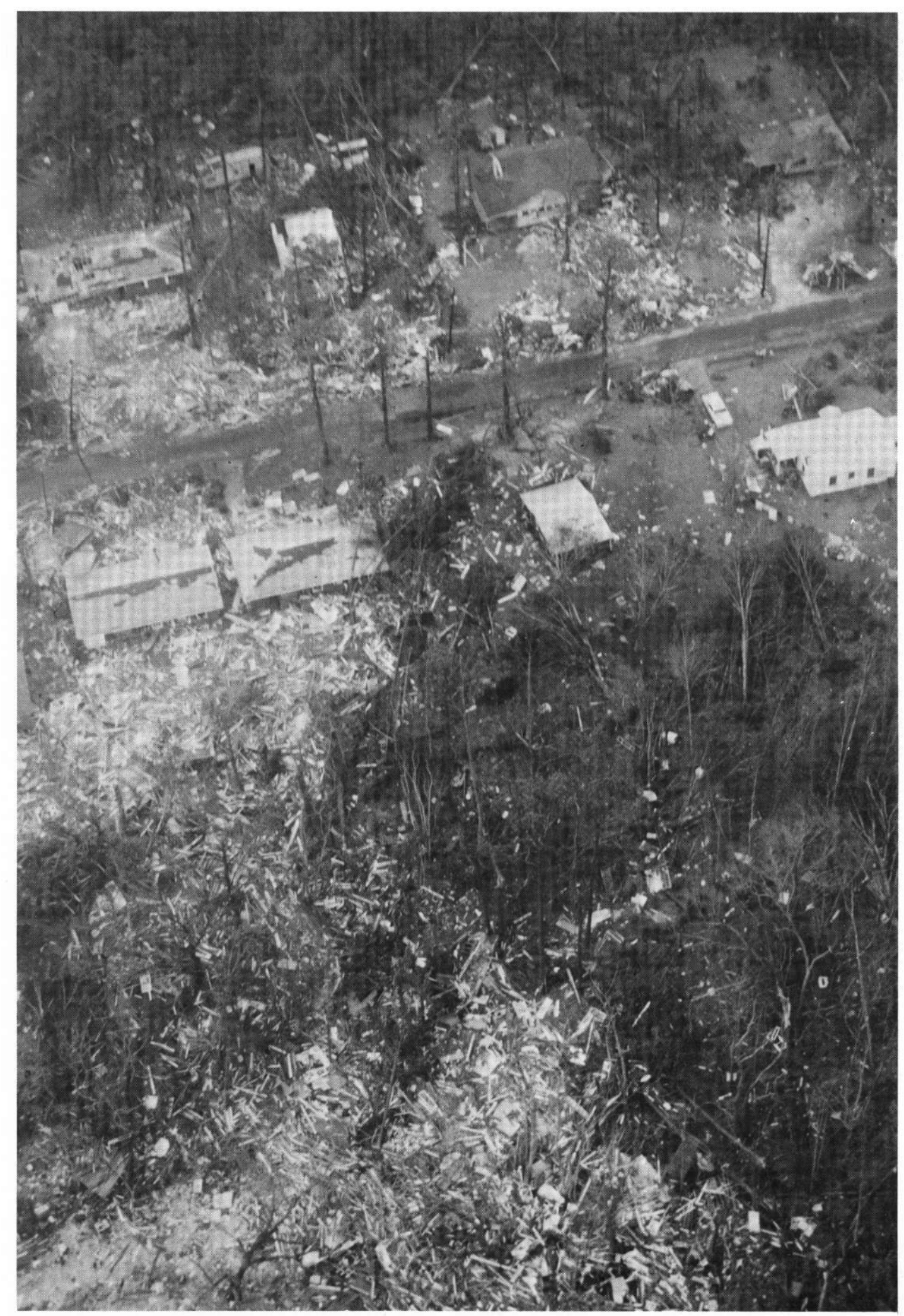

Figure 2.17 Residences and debris line in west Gulfport, Mississippi. 


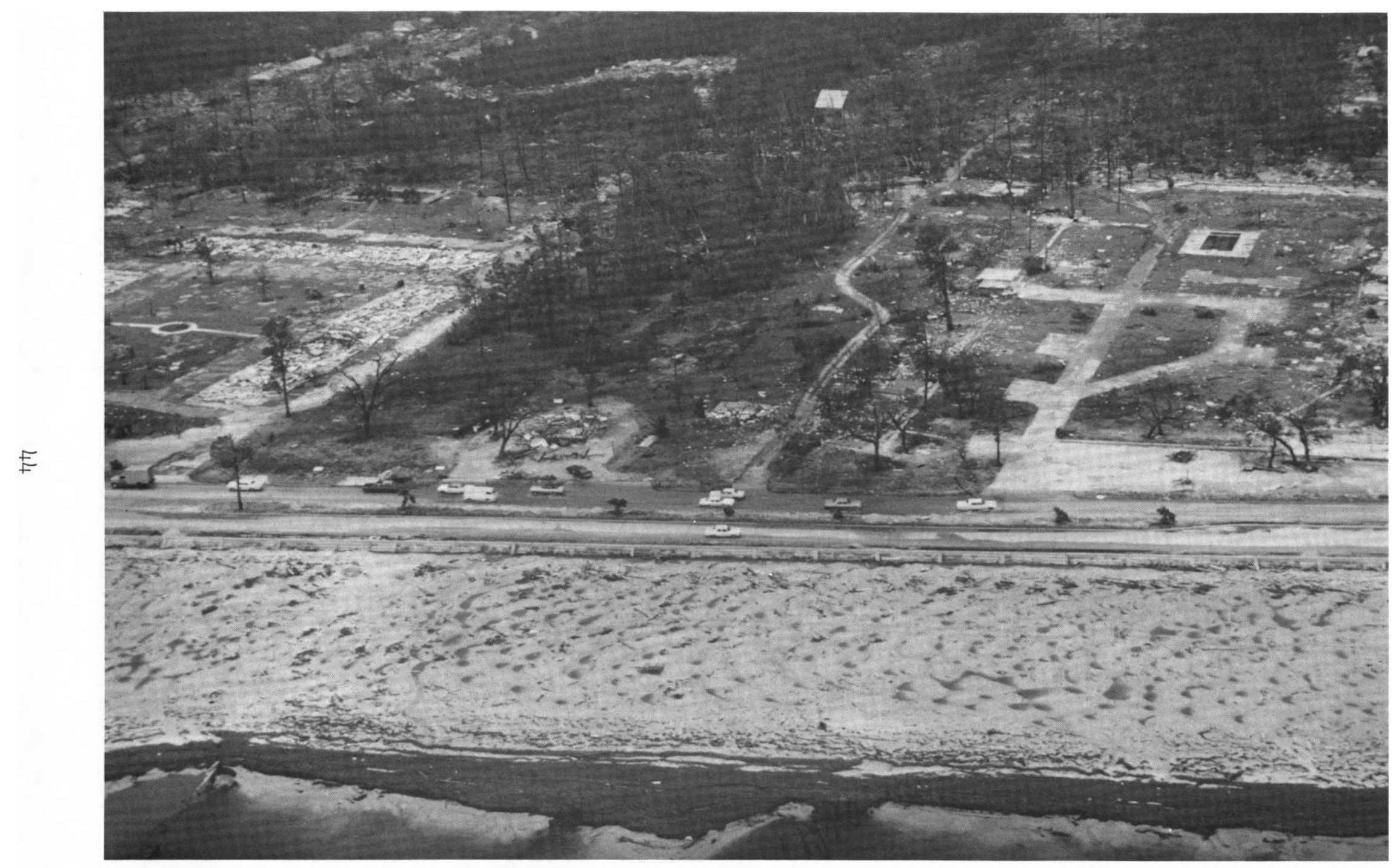

Figure 2.18 Remains of motels and apartments, Long Beach area. 


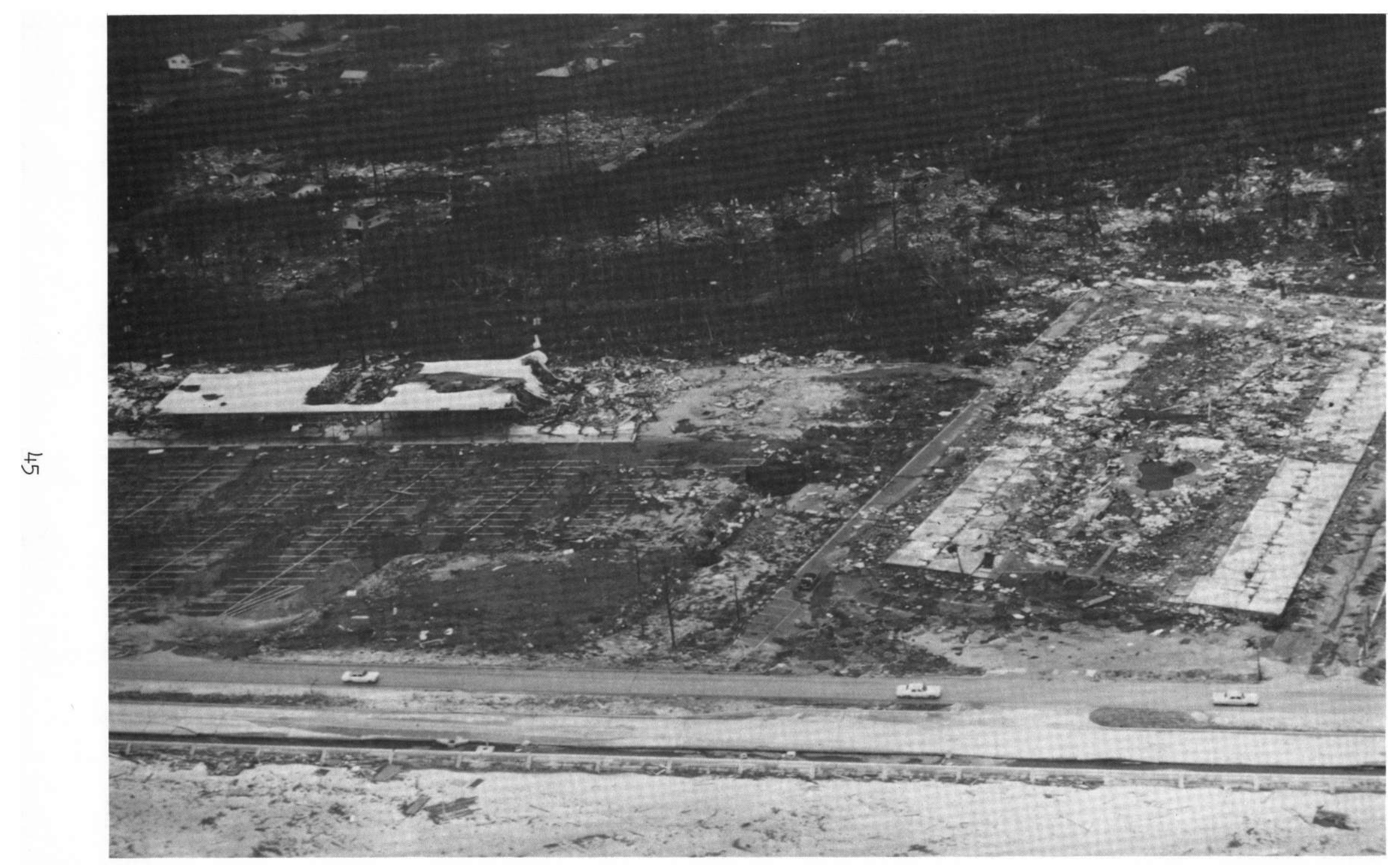

Figure 2.19 Gulf Plaza and apartments, east Pass Christian area 


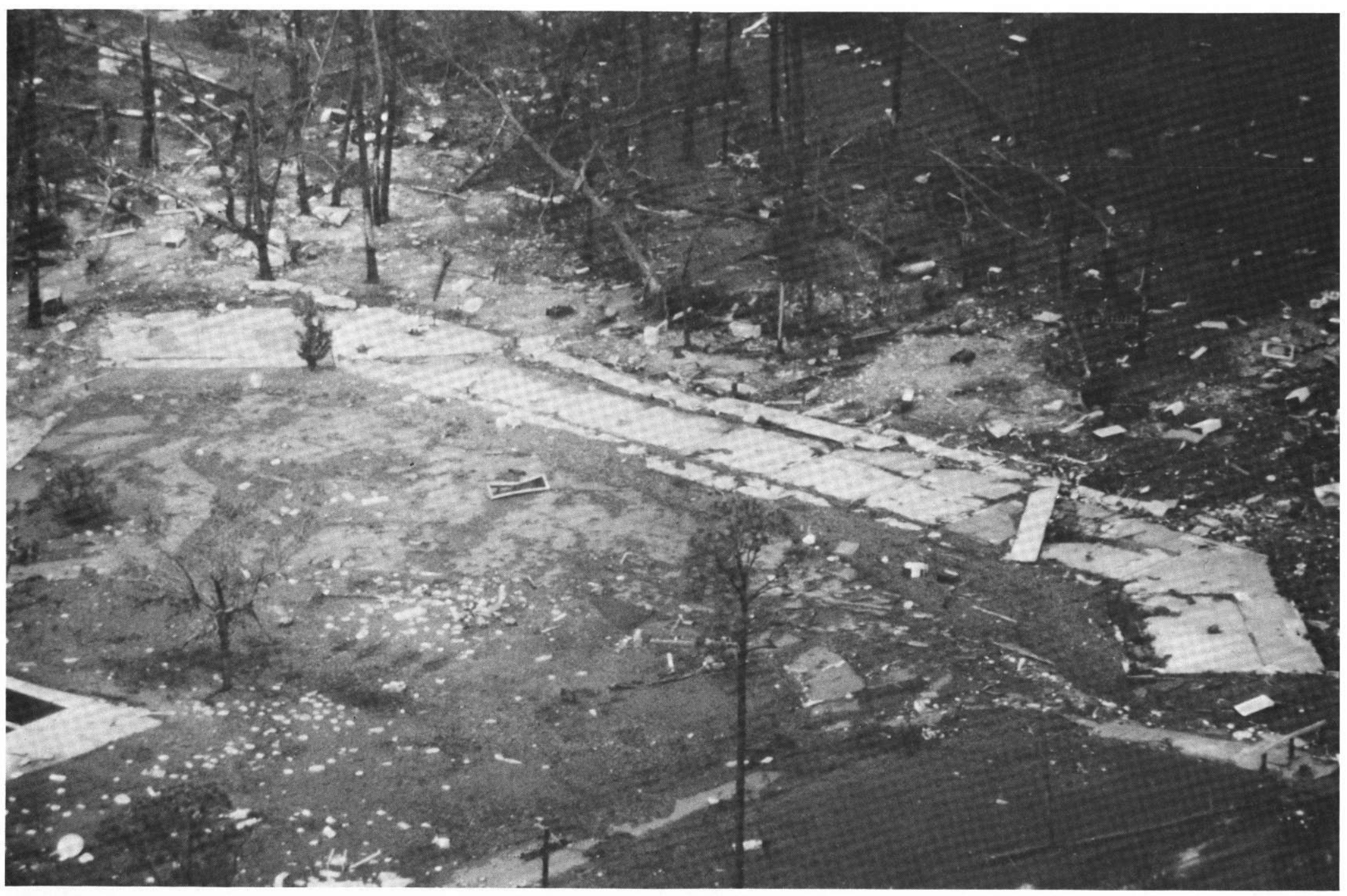

Figure 2.20 Motel building slab, between Pass Christian and Long Beach. 


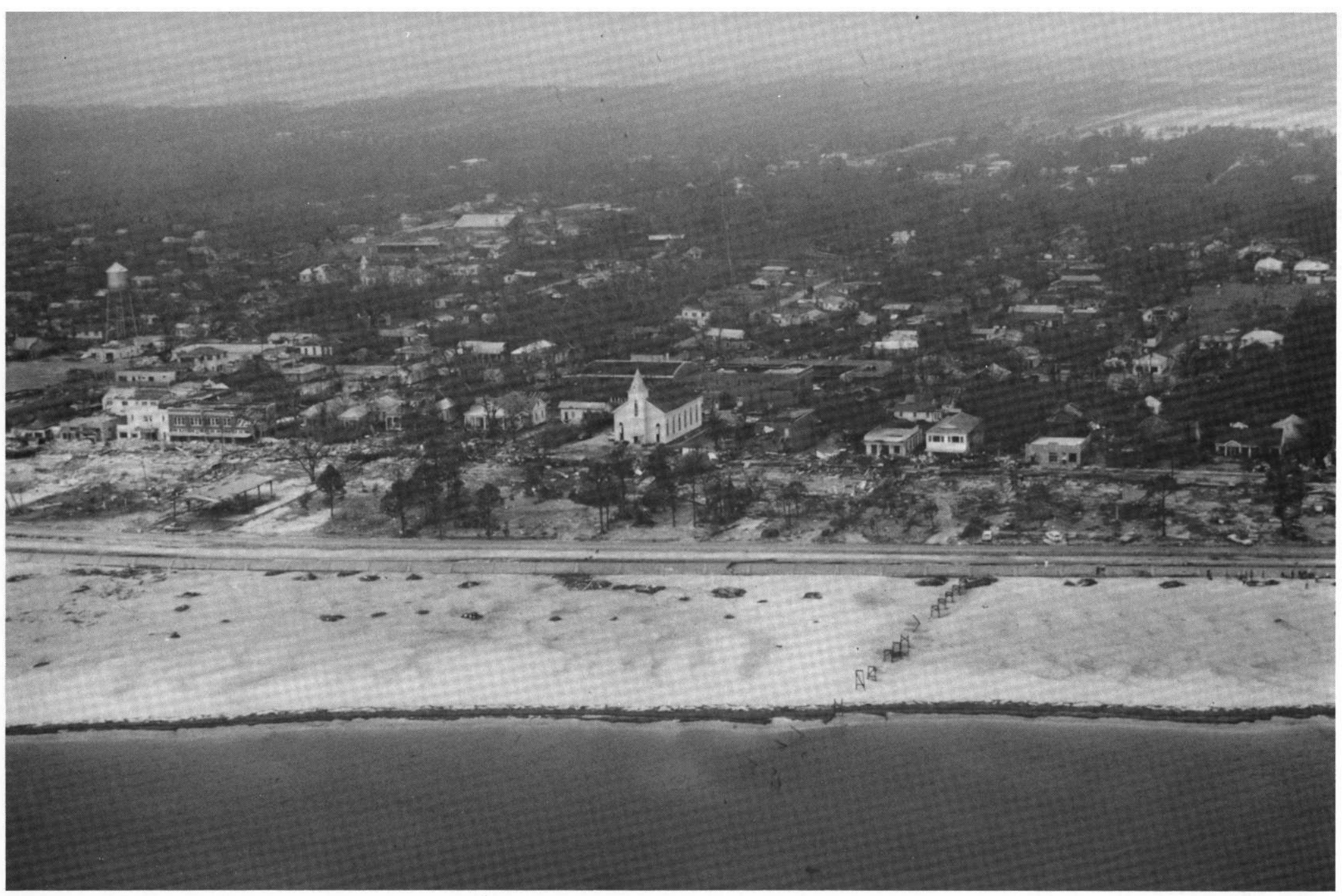

Figure 2.21 East end of Pass Christian downtown area. 


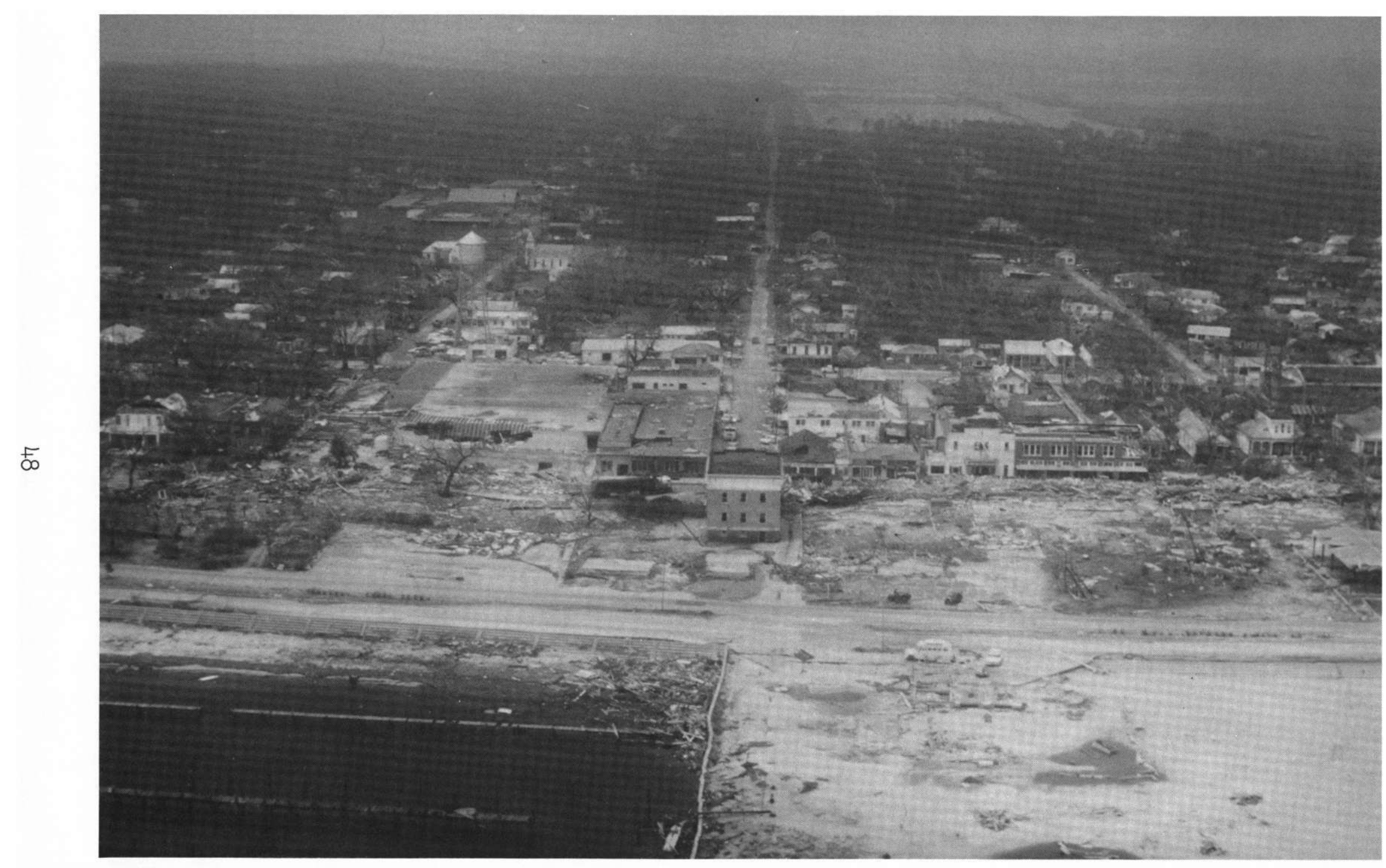

Figure 2.22 Pass Christian, Mississippi. 


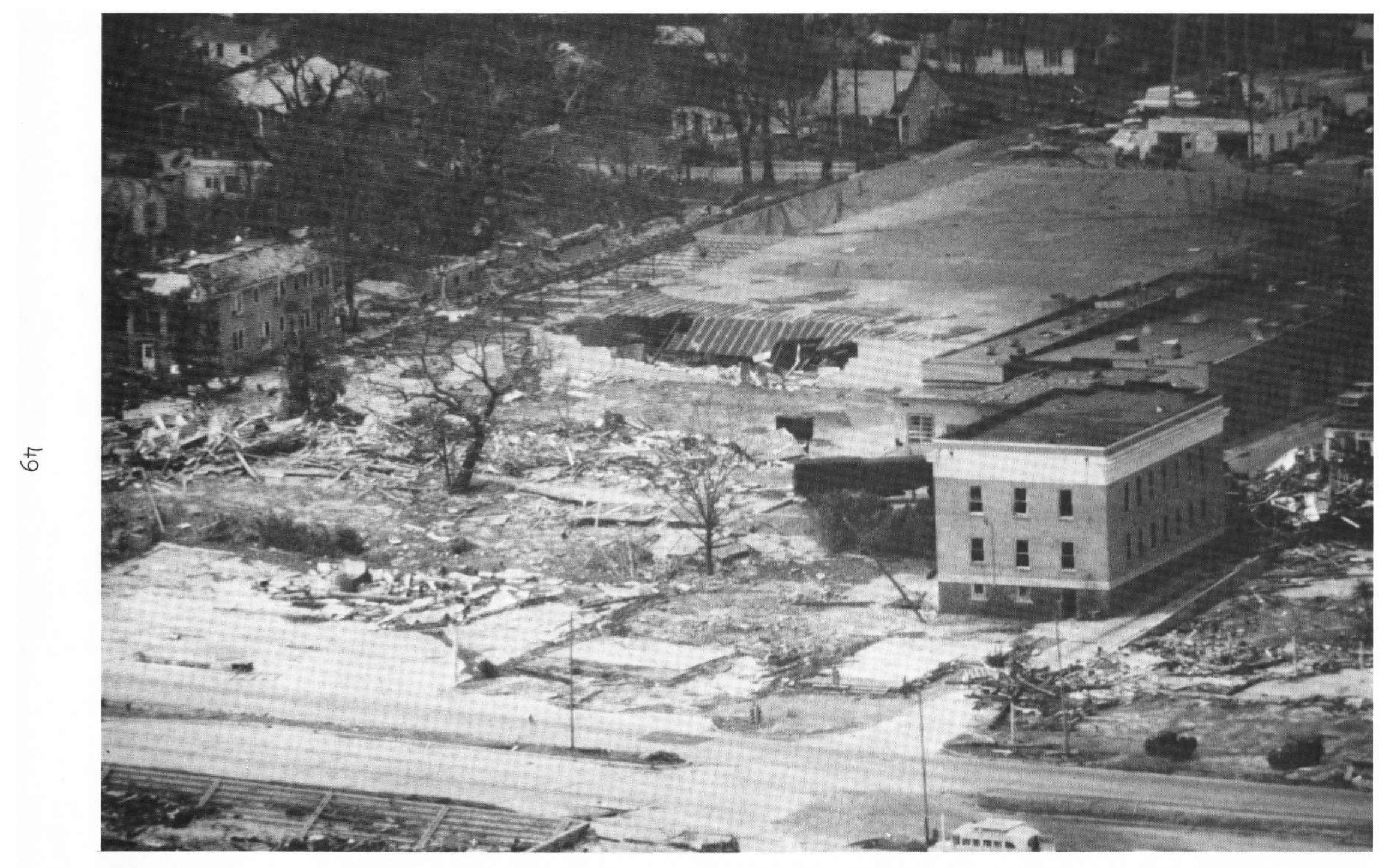
Figure 2.23 Pass Christian, City Hall in foreground. 


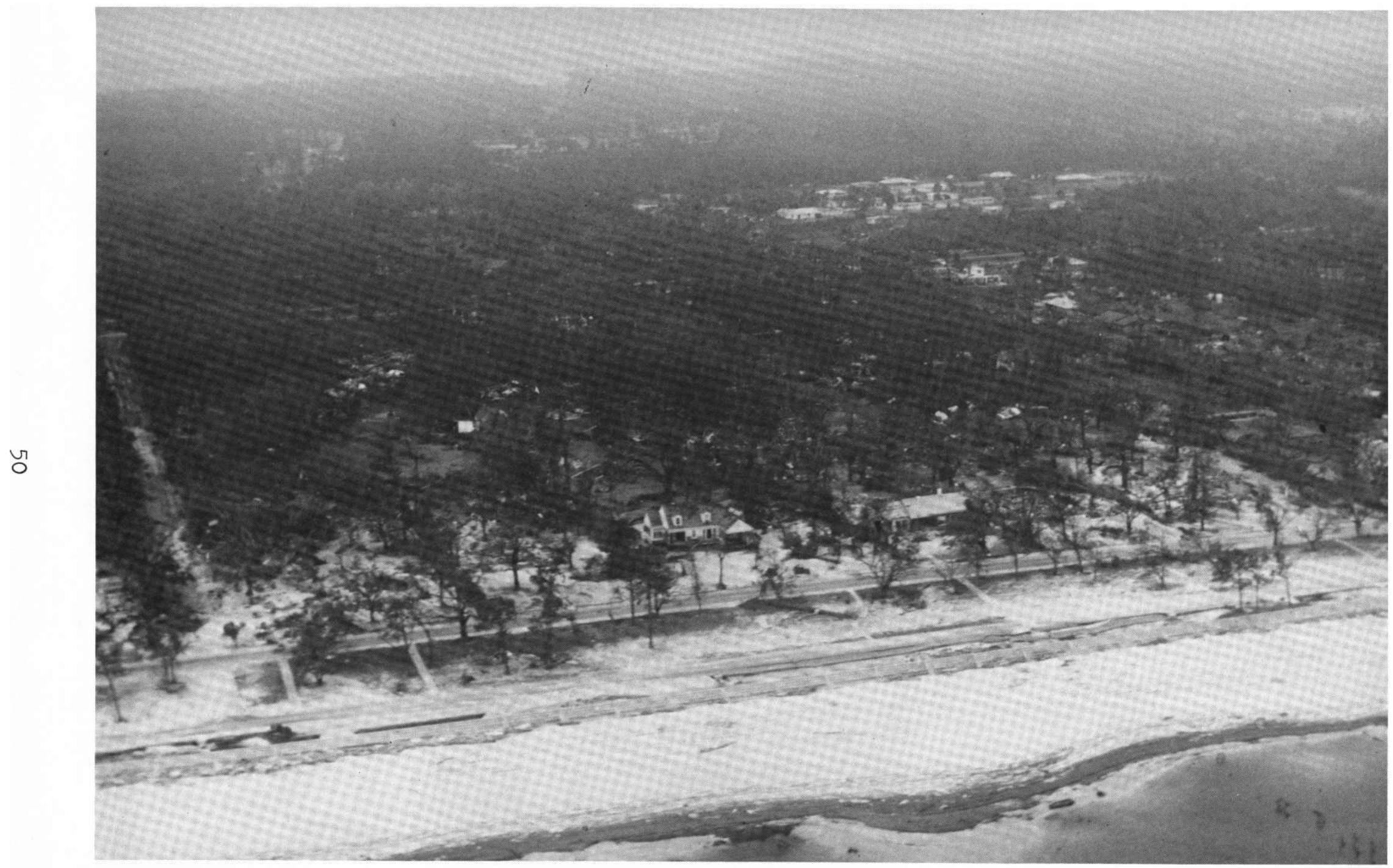

Figure 2.24 West Pass Christian, Mississippi. 


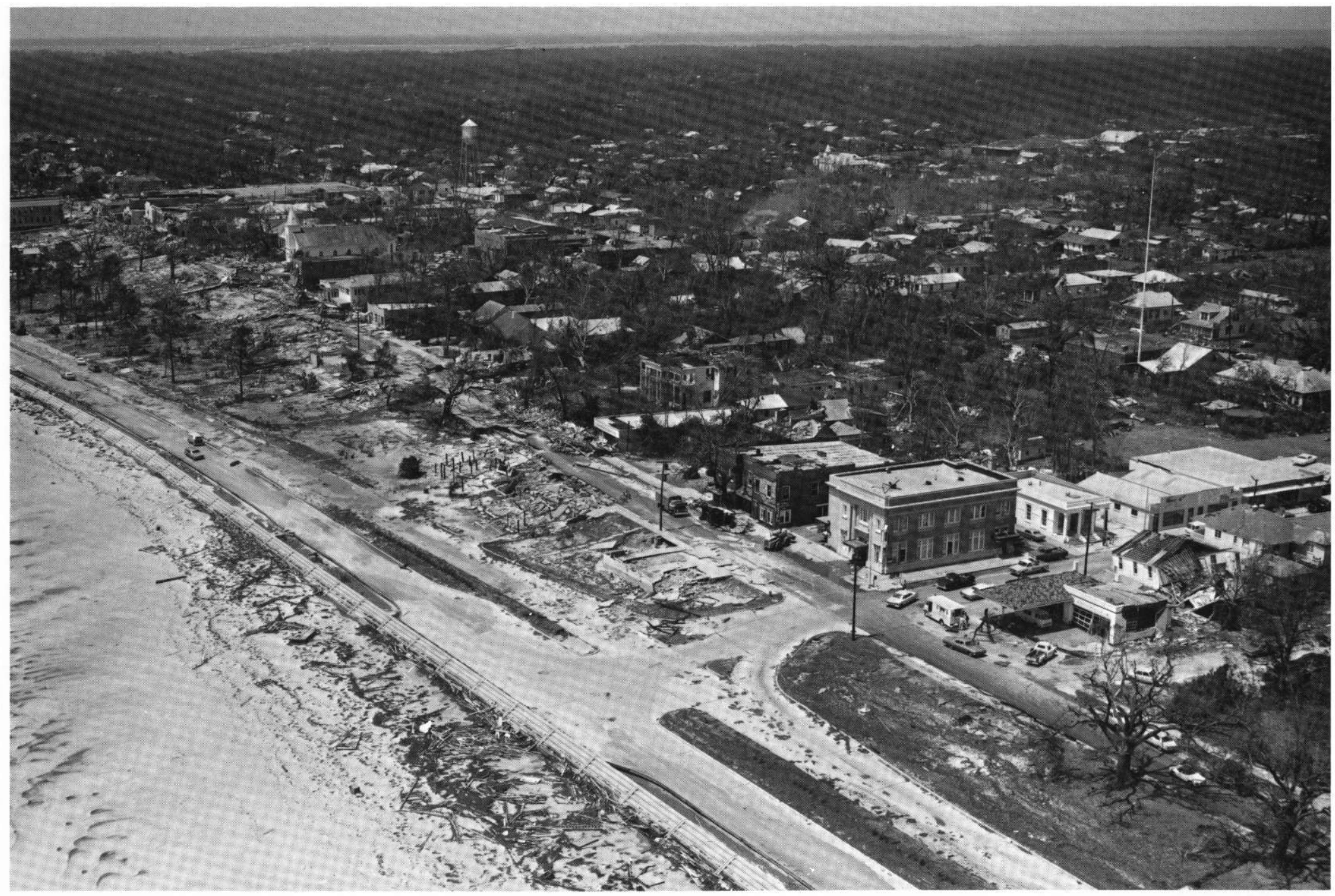

Figure 2.25 Pass Christian, Mississippi. 


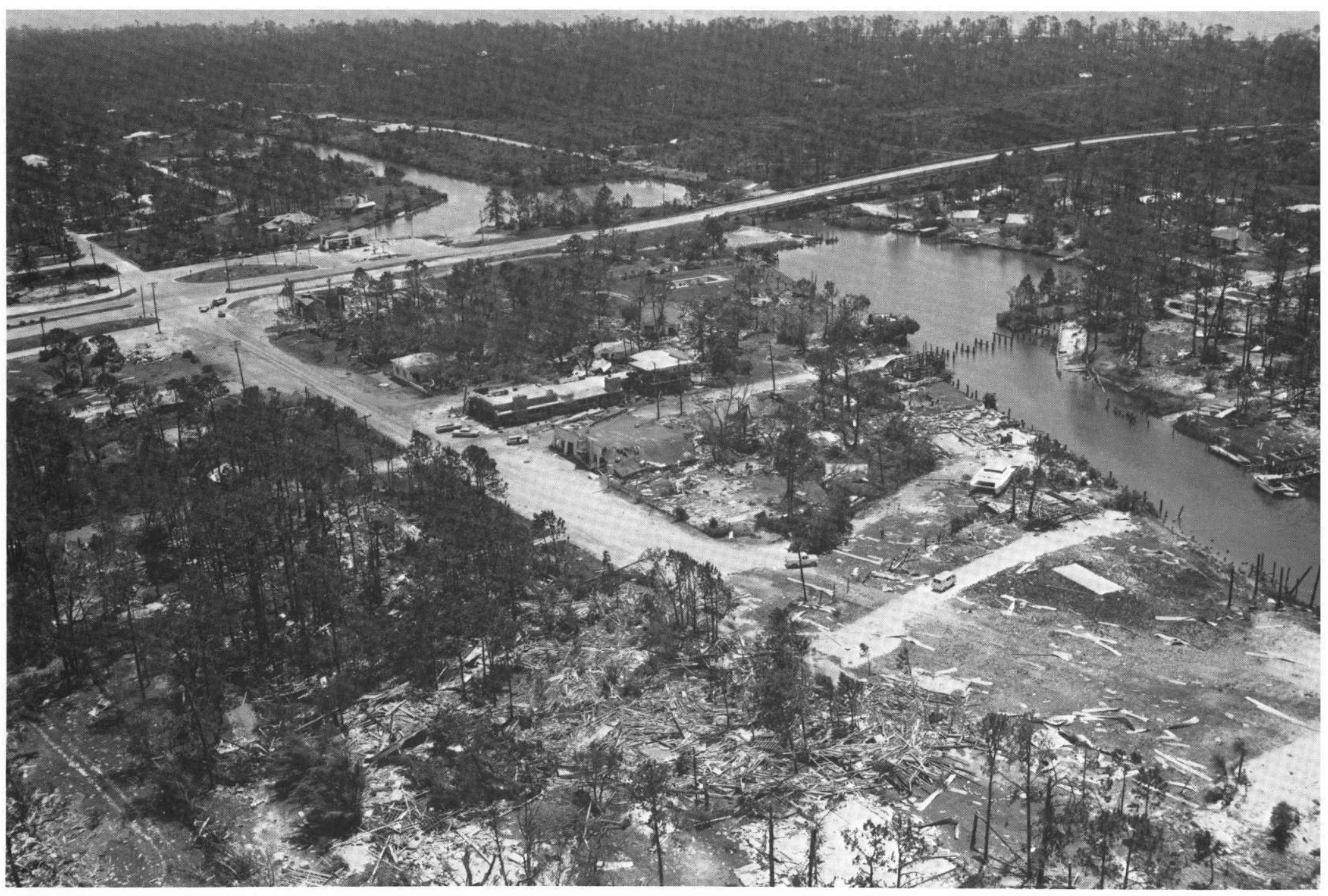

Figure 2.26 Henderson Point, on east shore of Saint Louis Bay, Mississippi. 


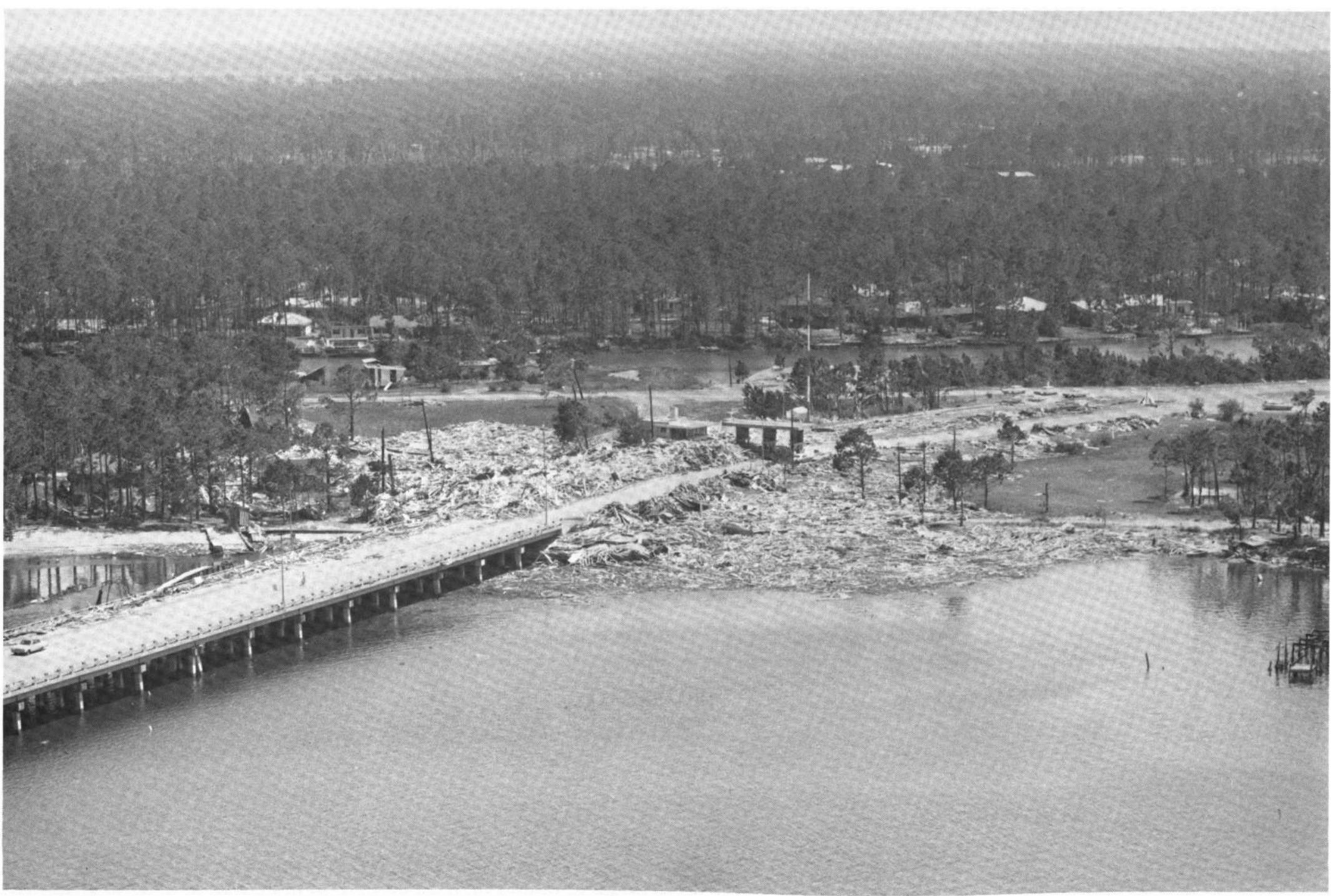

Figure 2.27 Debris at east end of Bay Saint Louis Bridge, Mississippi. 


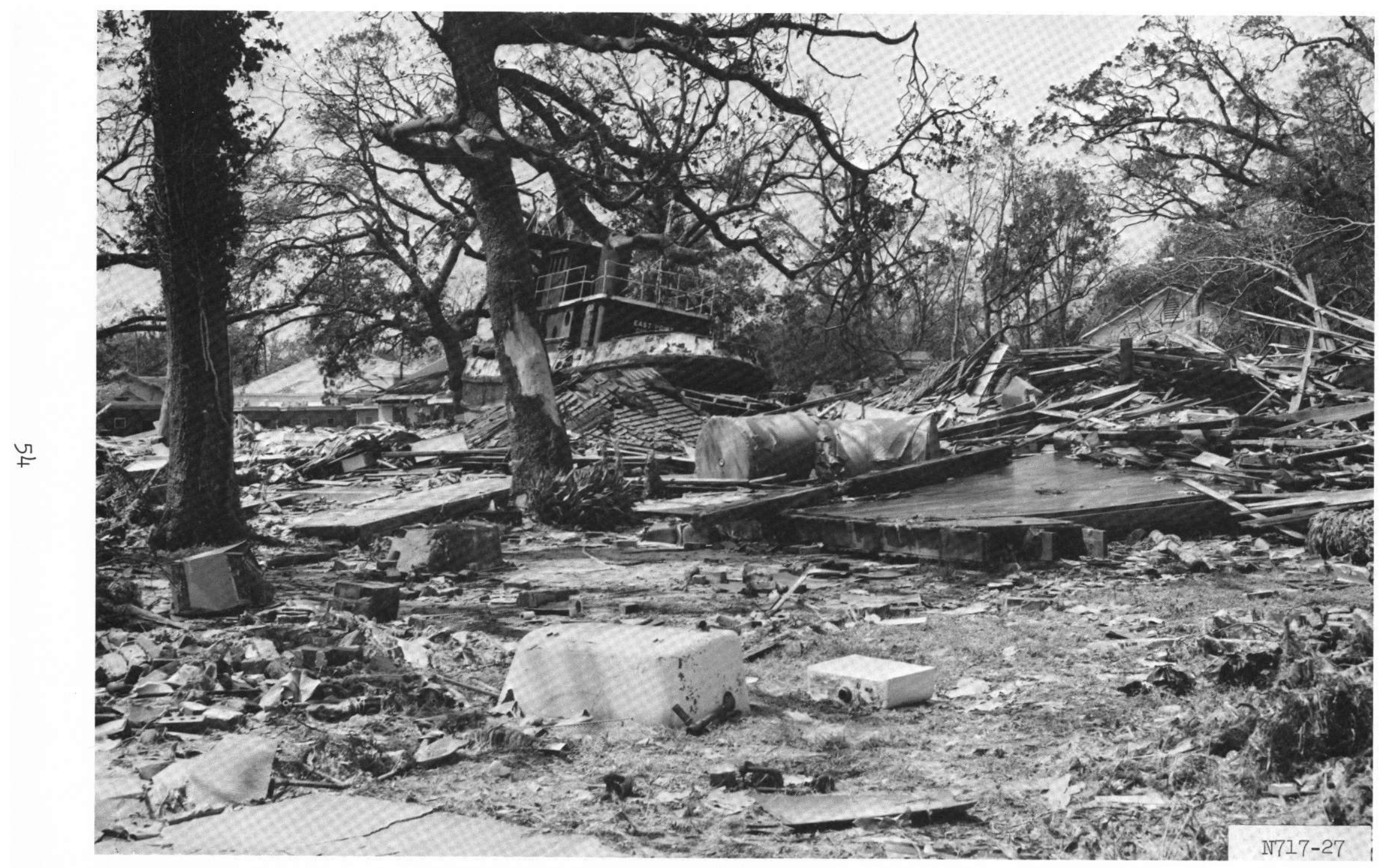

Figure 2.28 Tug and paper rolls in debris, west Gulfport, Mississippi. 


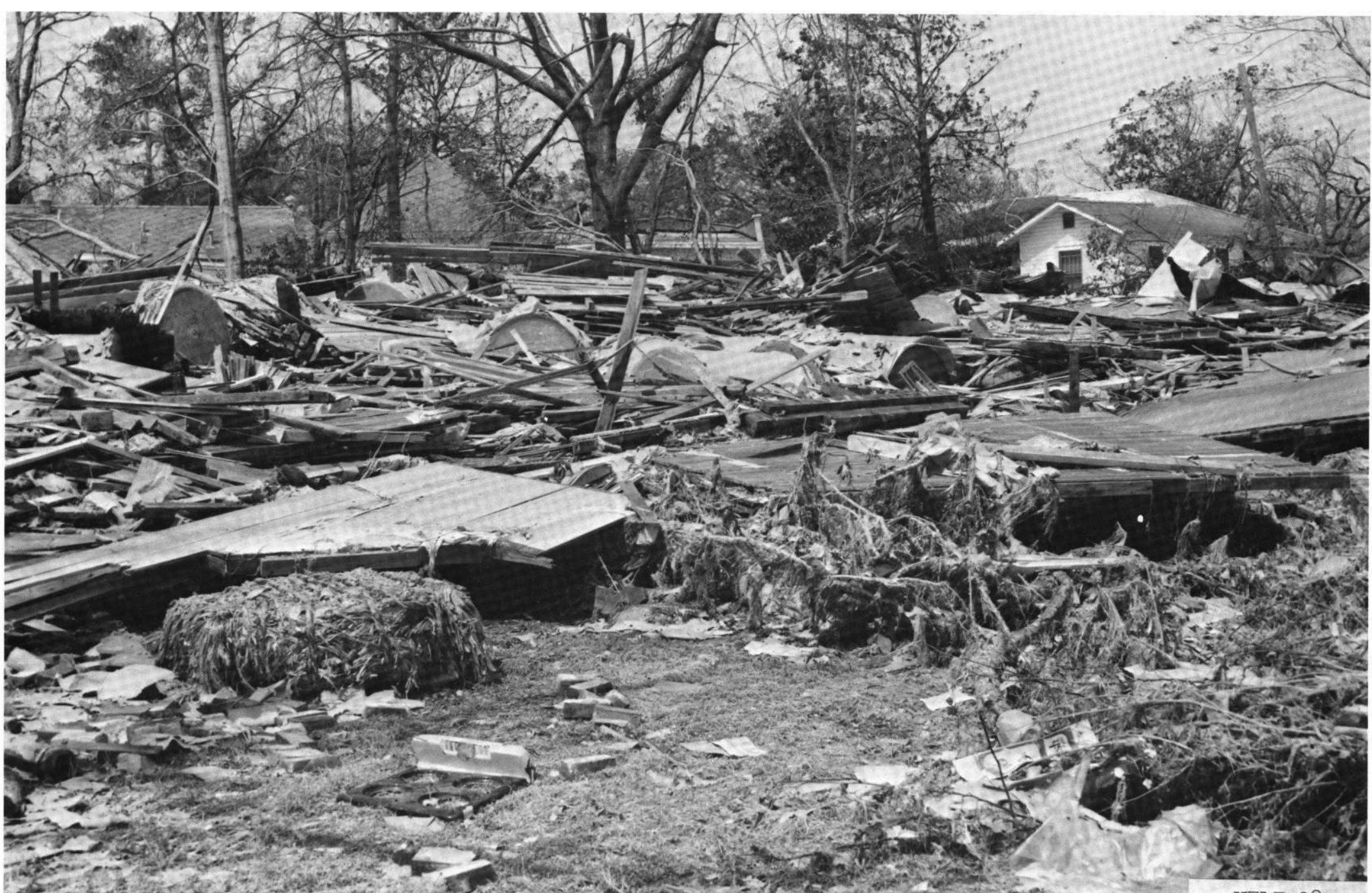

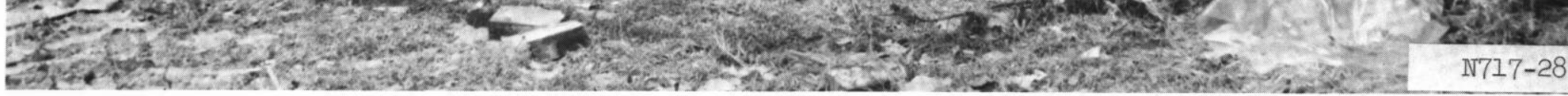

Figure 2.29 Debris from residences and Port facilities, west Gulfport, Mississippi. 


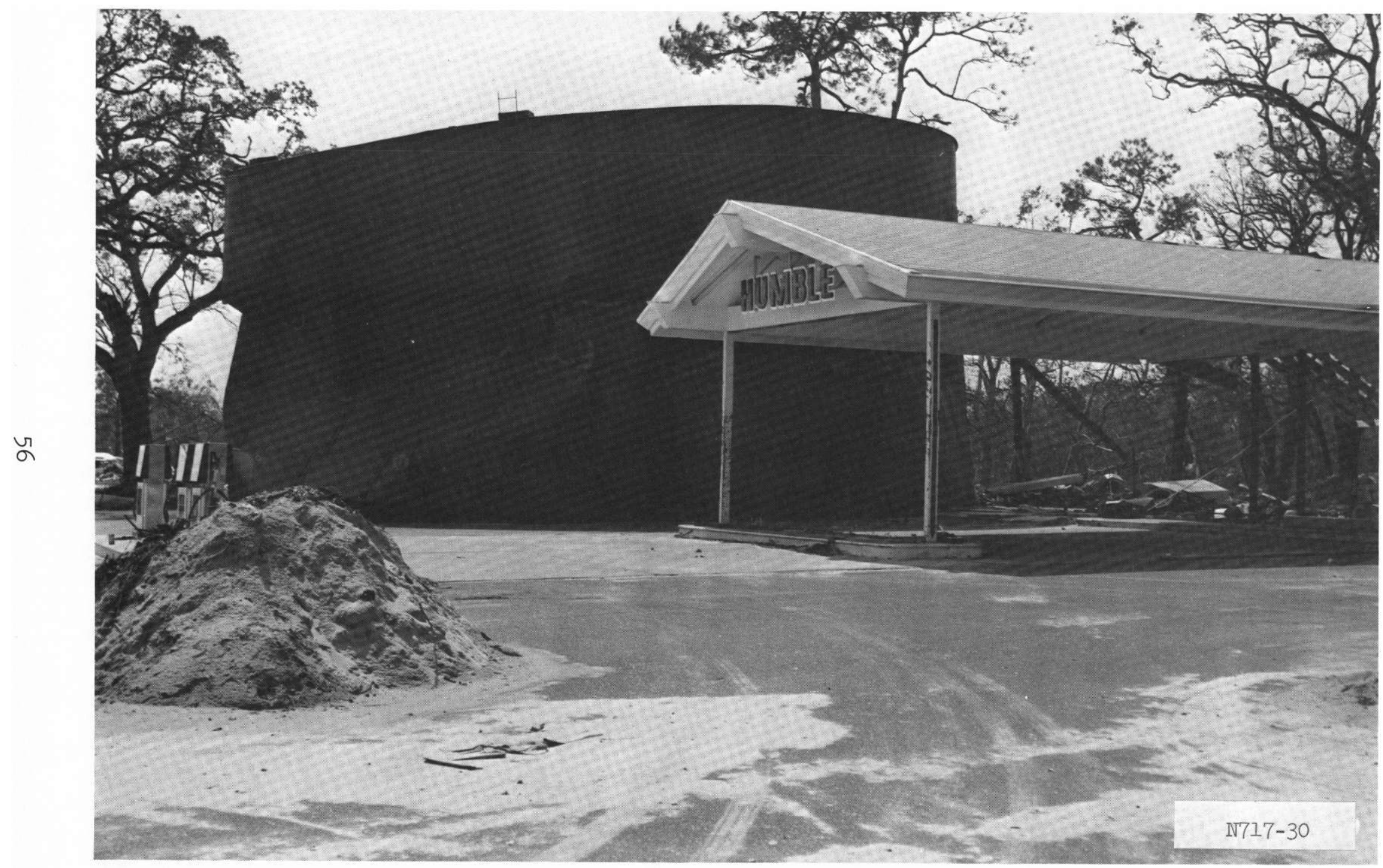

Figure 2.30 Tank floated in from harbor, west Gulfport, Mississippi. 


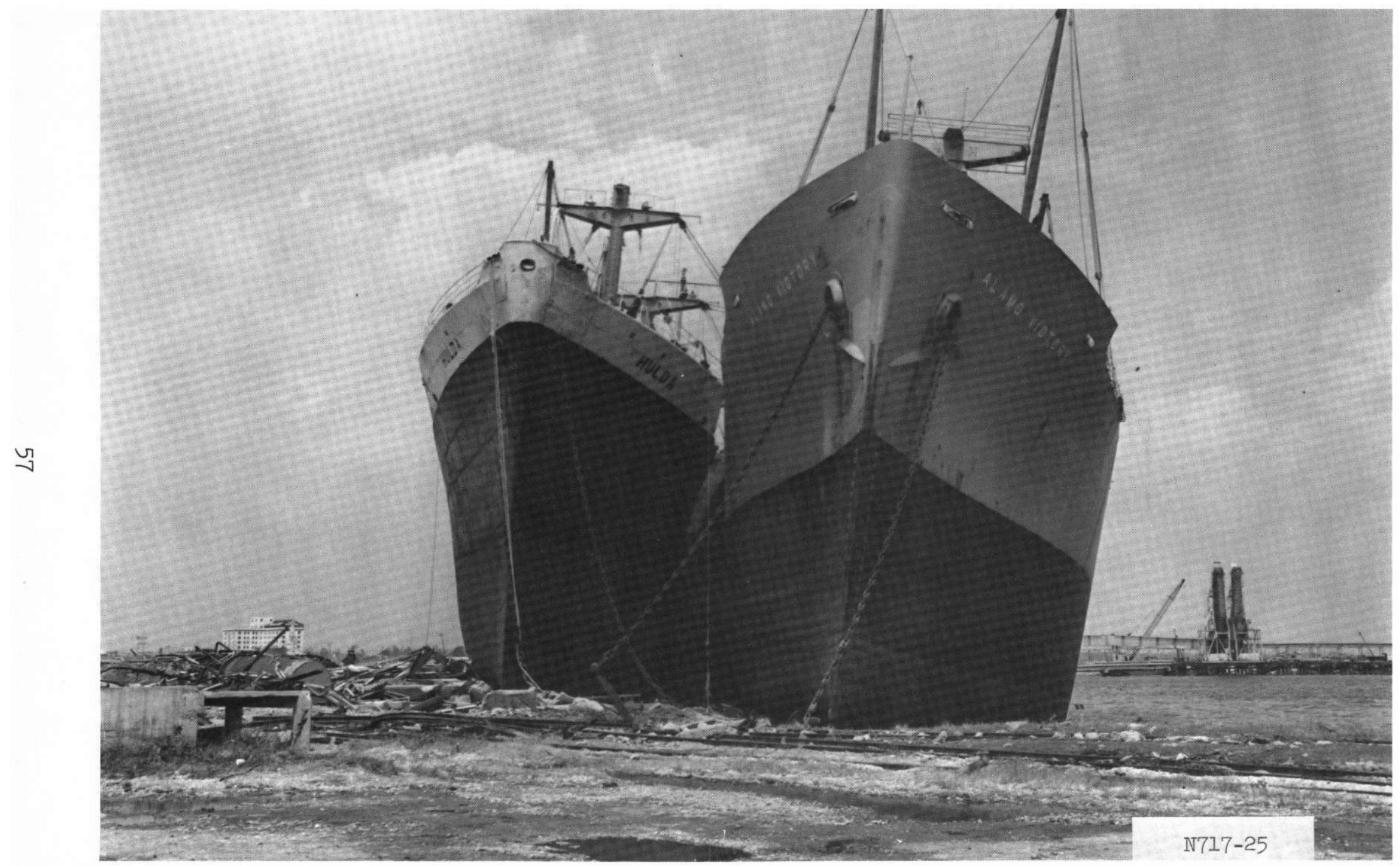

Figure 2.31 Ships aground, Port of Gulfport. 


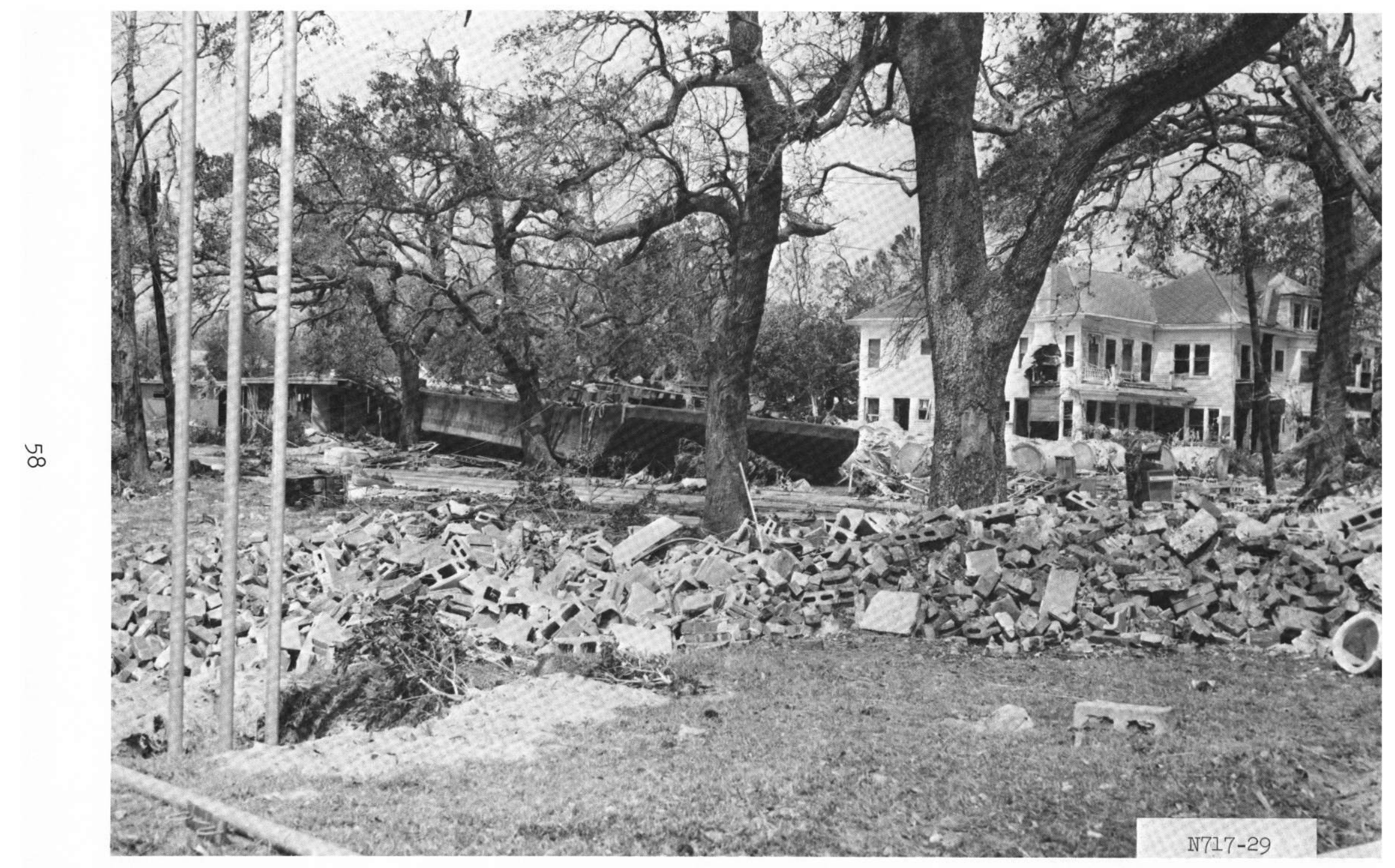

Figure 2.32 Barge, debris, and damaged residence, west Gulfport, Mississippi. 


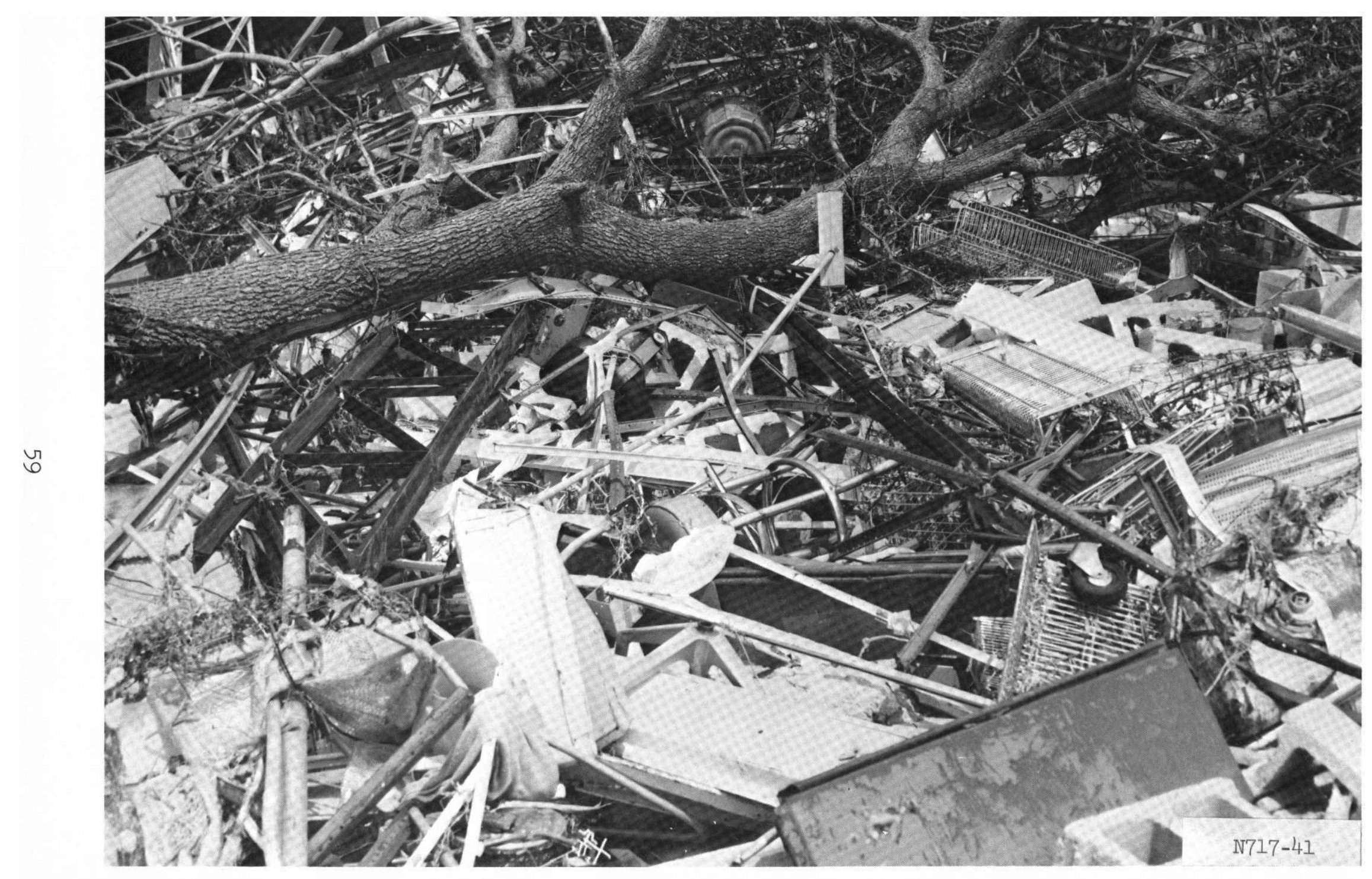

Figure 2.33 Debris of a shopping center, Long Beach, Mississippi. 


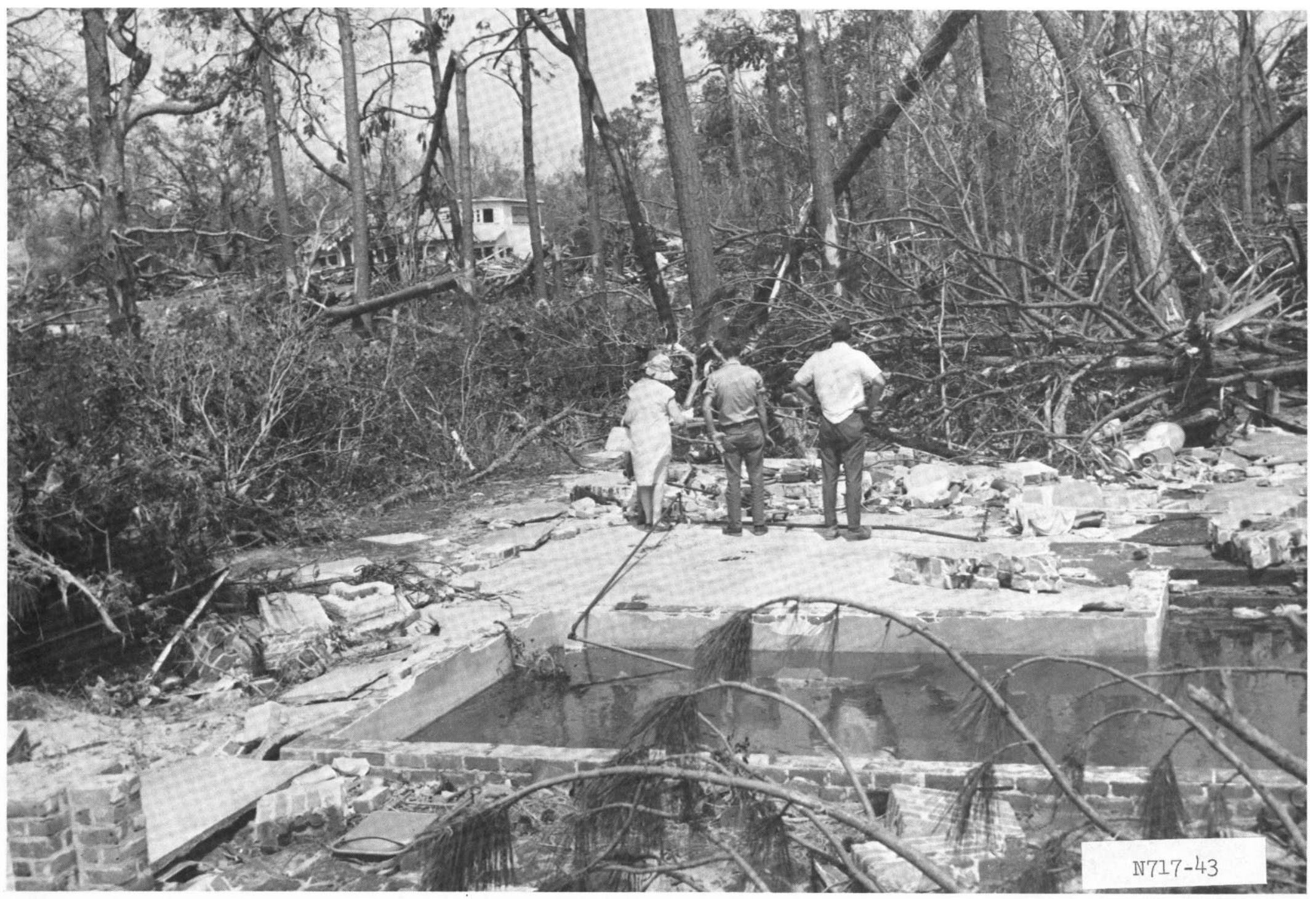

Figure 2.34 Destroyed residence from front doorsteps, Long Beach, Mississippi. 


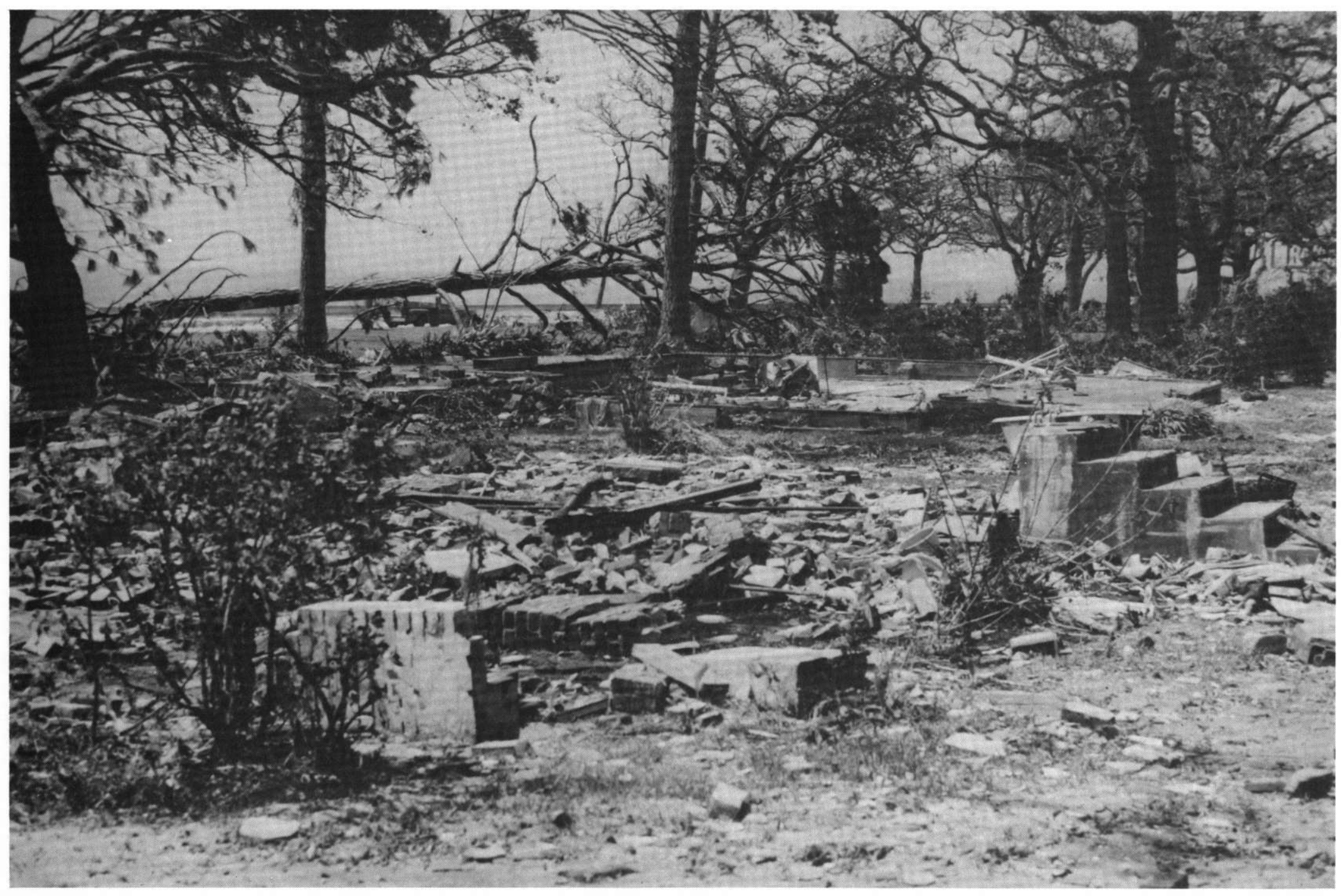

Figure 2.35 Residence near Long Beach, Mississippi. 


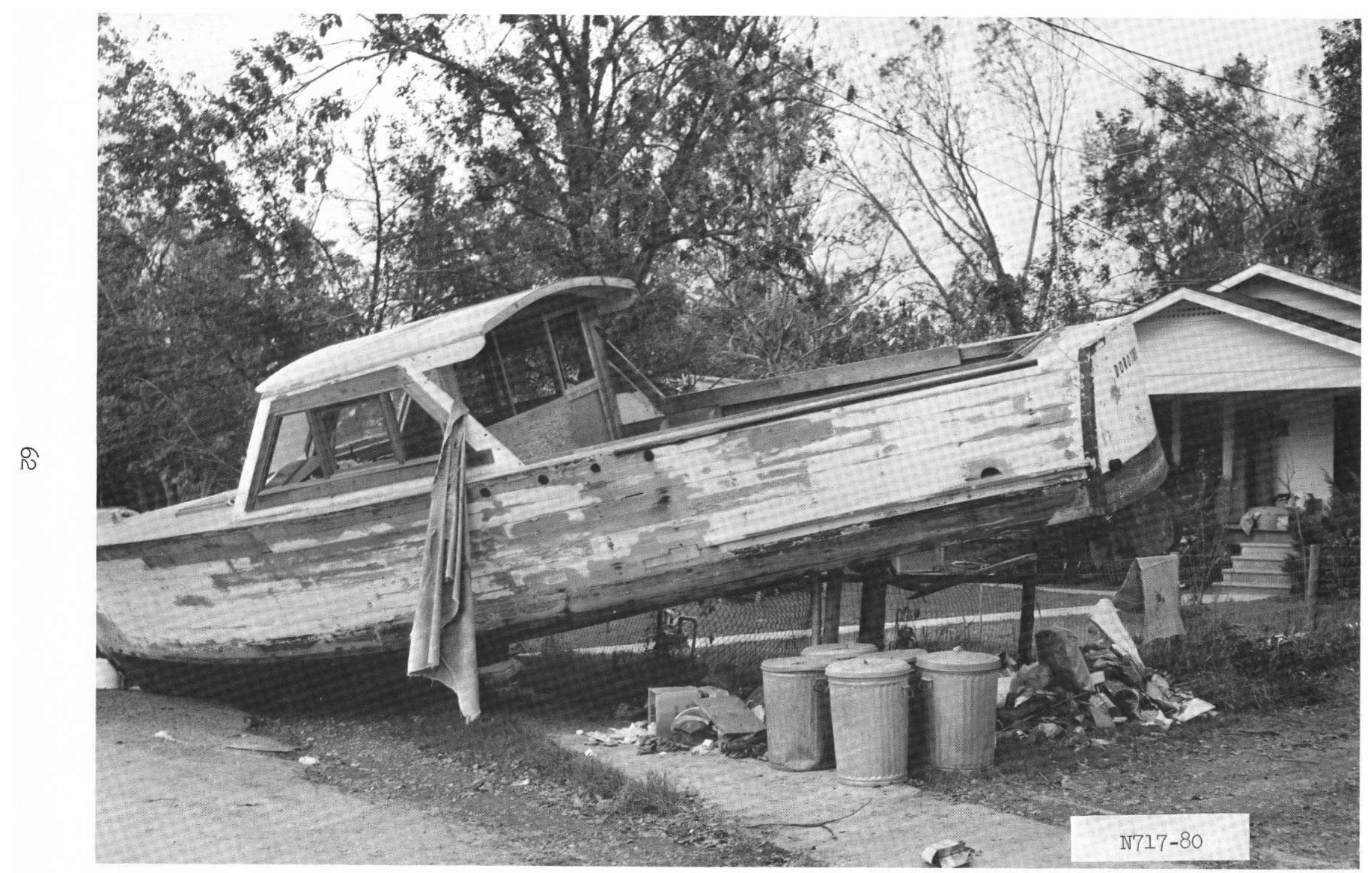

Figure 2.36 Boat ashore, east end of Biloxi, Mississippi. 


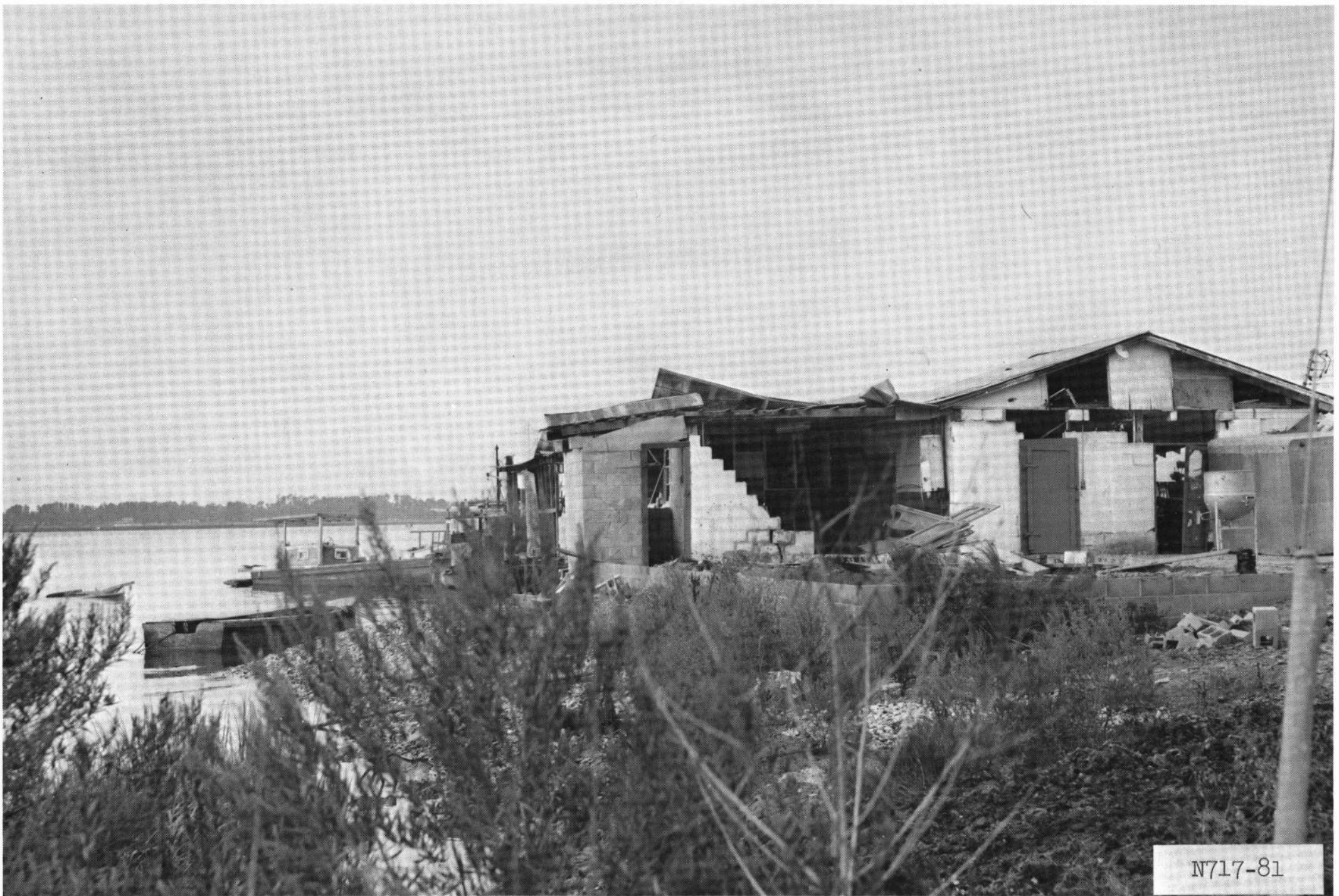

Figure 2.37 Commercial building, Back Bay of Biloxi, Mississippi. 


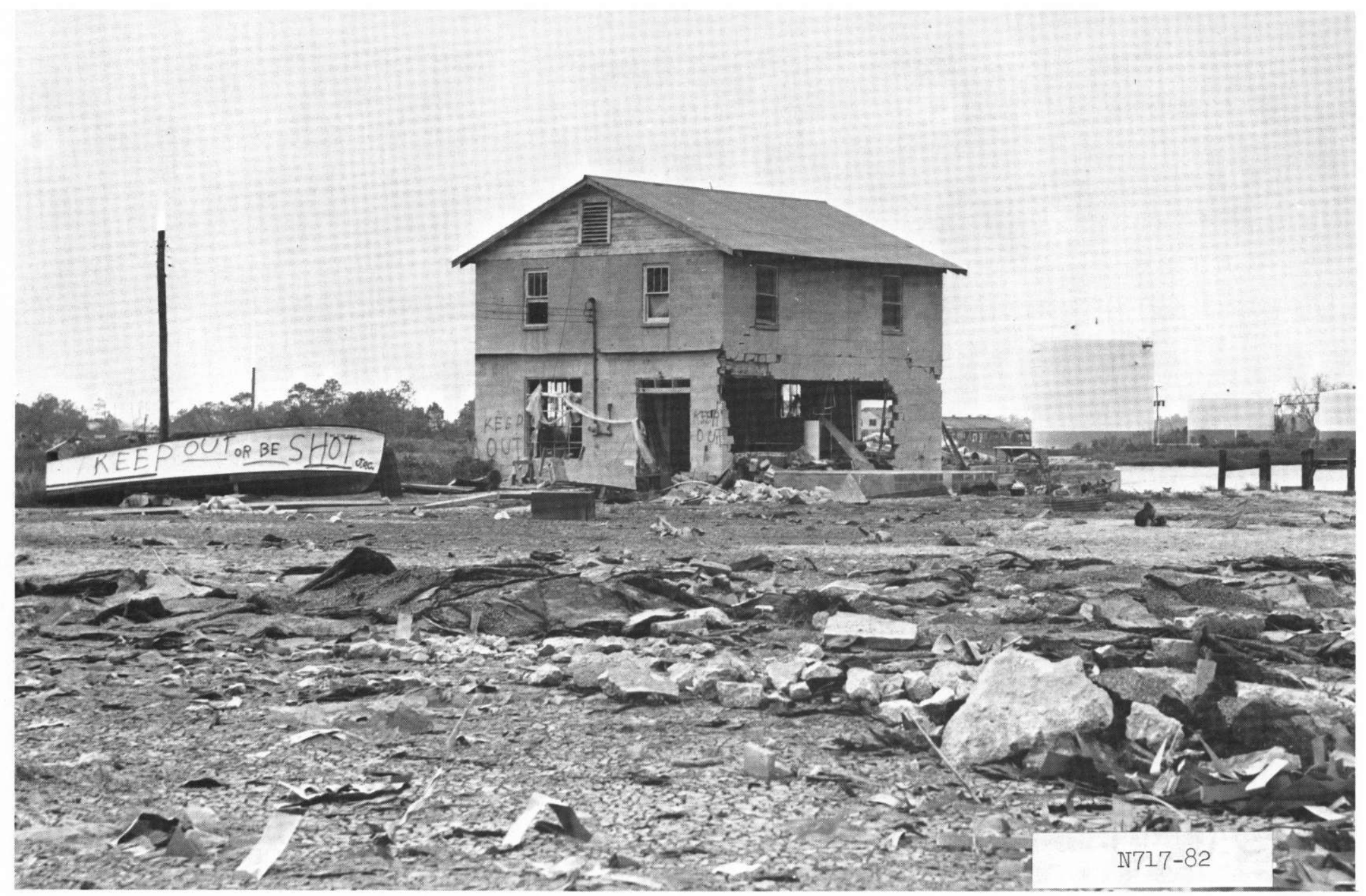

Figure 2.38 Water-damaged building, Back Bay of Biloxi. 


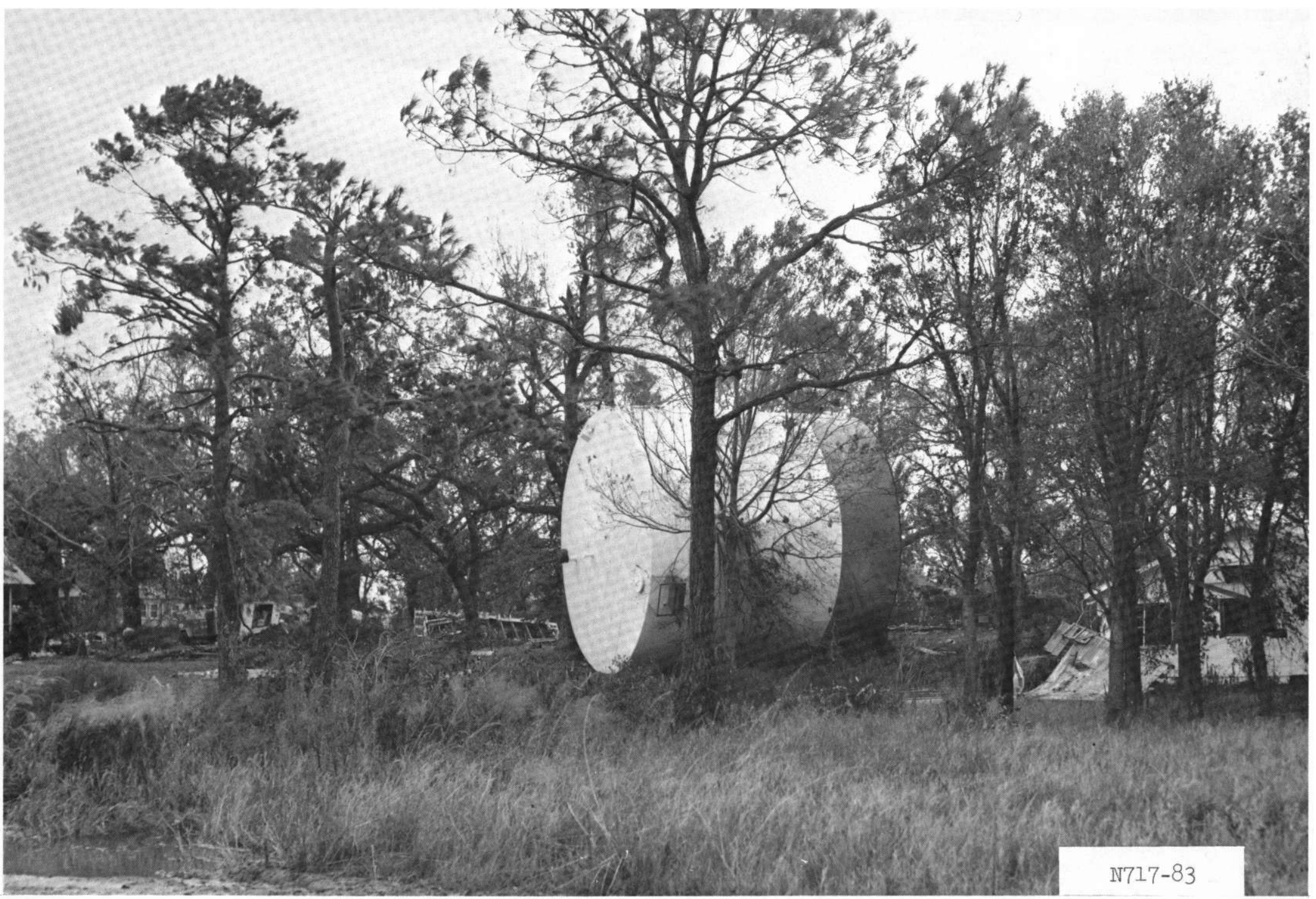

Figure 2.39. Oil storage tank floated inland, Back Bay of Biloxi. 


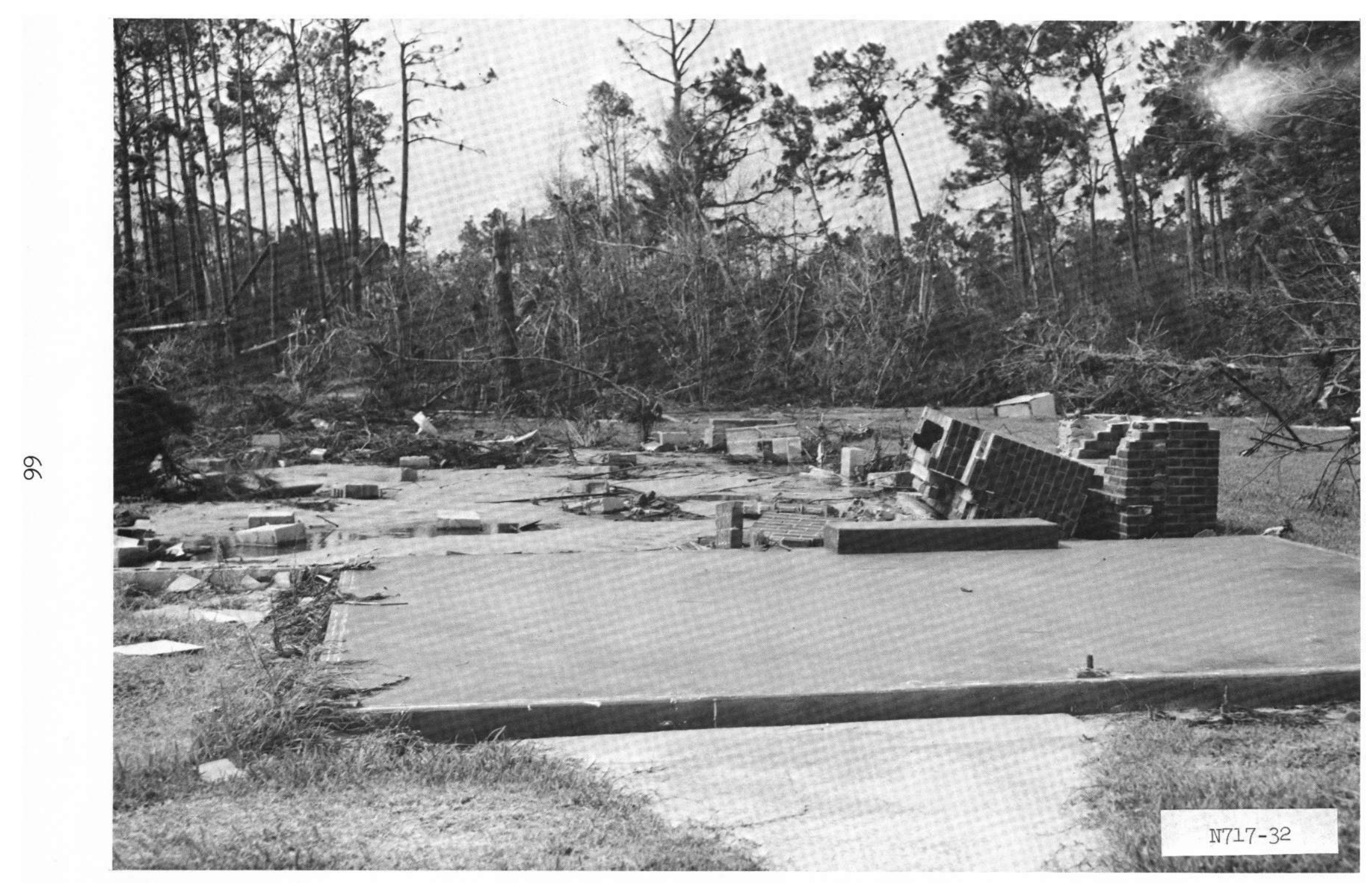

Figure 2.40 Remains of brick and block residence, Long Beach area. 


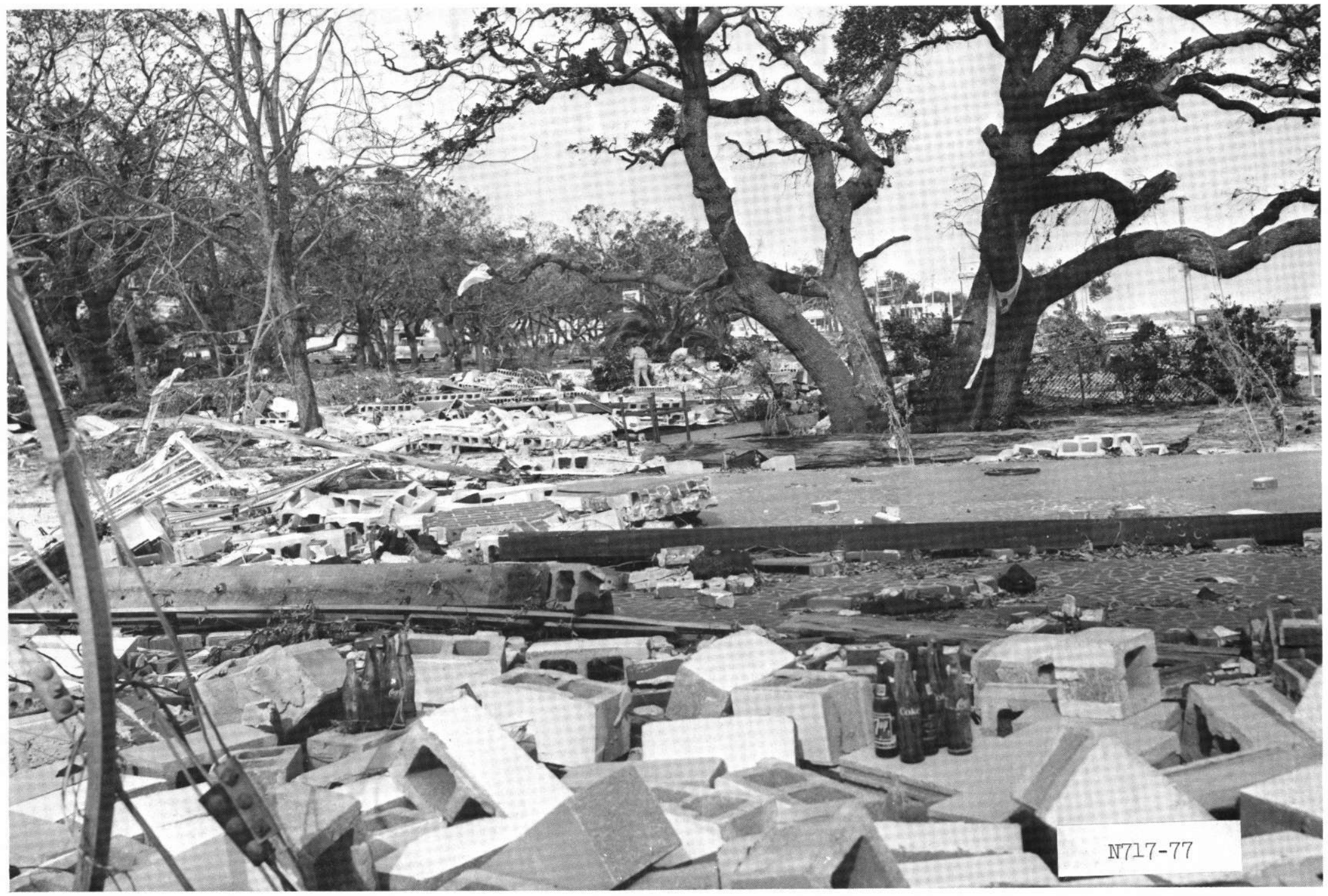

Figure 2.41 Motels, west of Biloxi, Mississippi. 


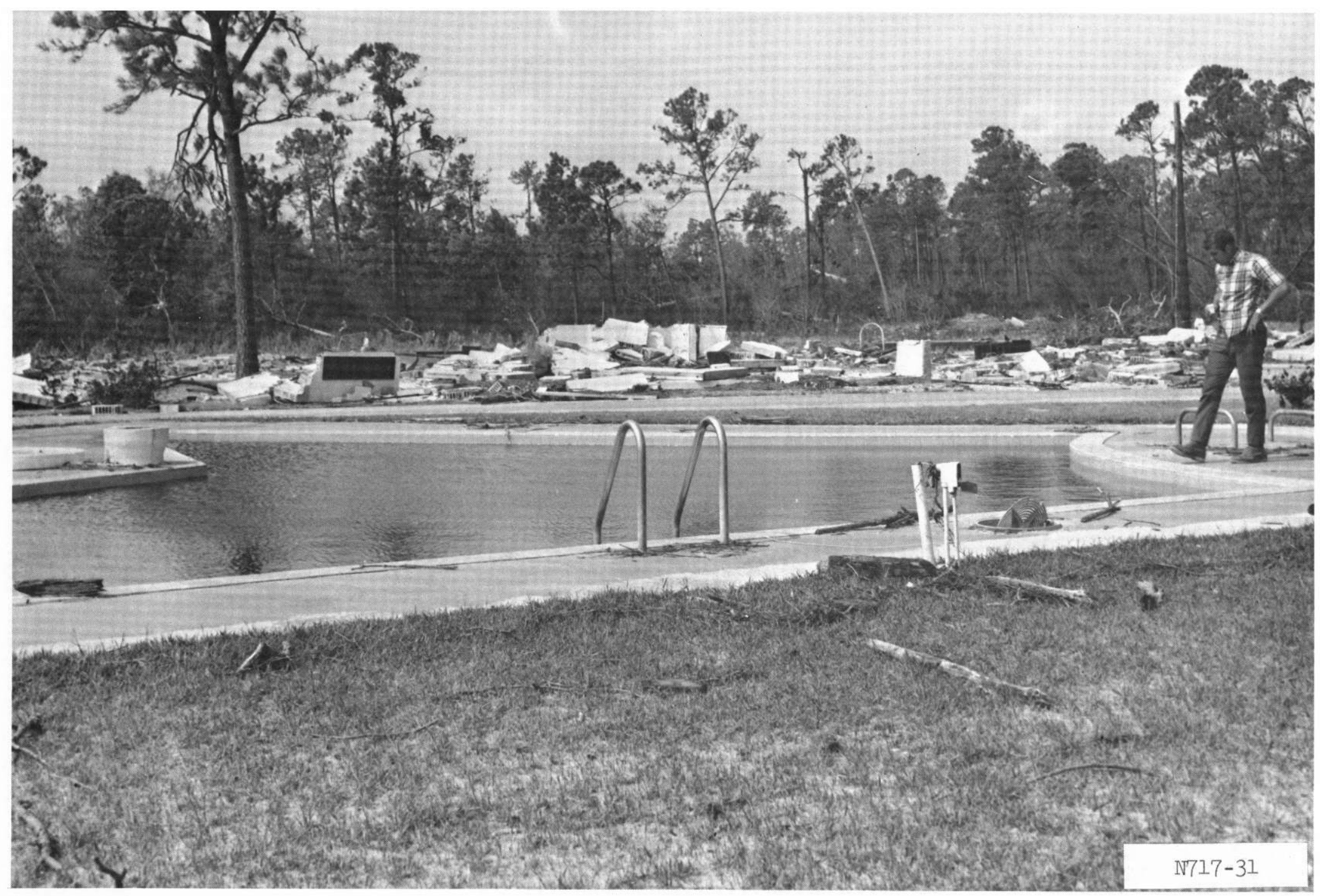

Figure 2.42 Motel or apartment house, Long Beach area. 


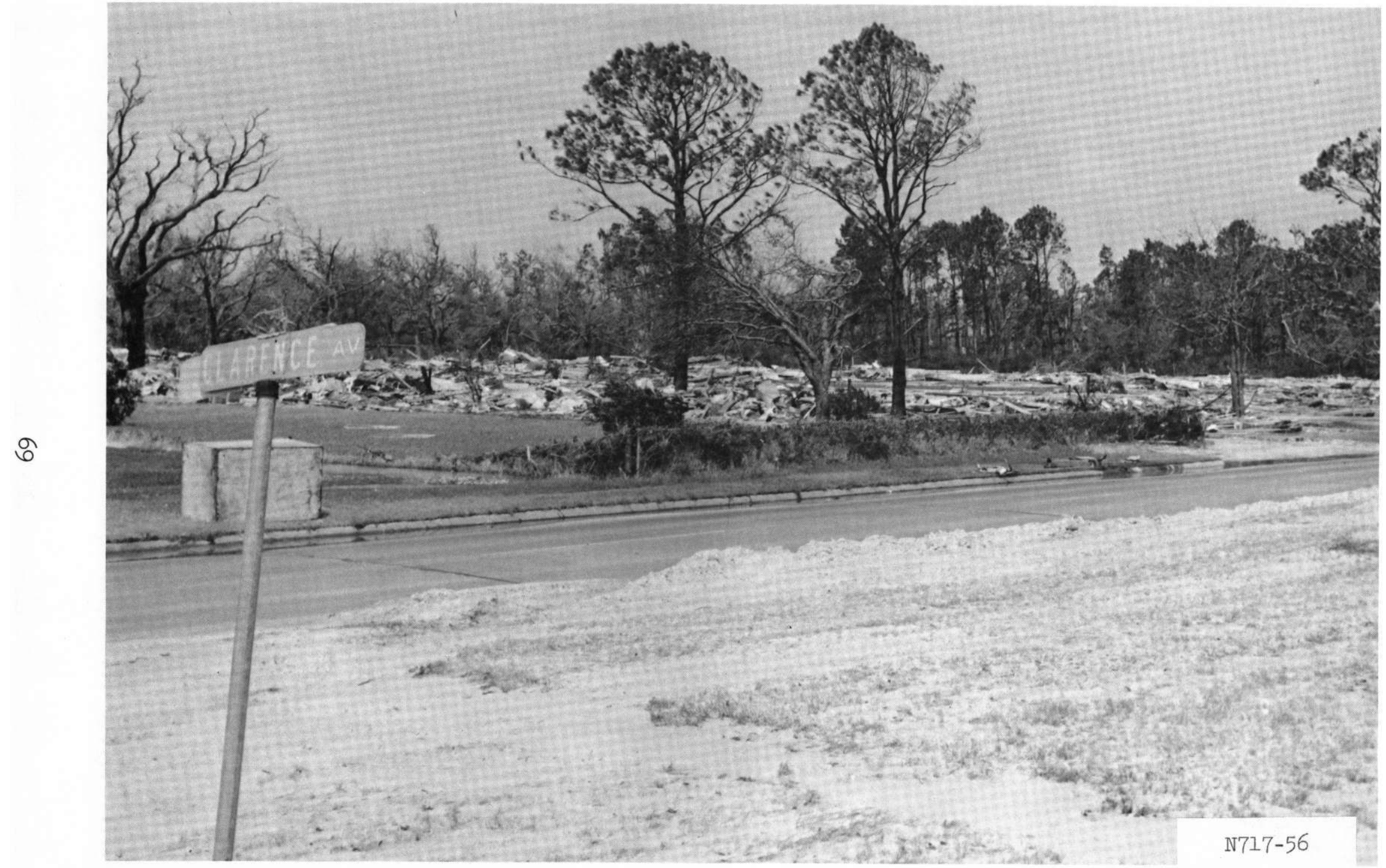

Figure 2.43 Richelieu Apartments (23 dead), Pass Christian, Mississippi. 


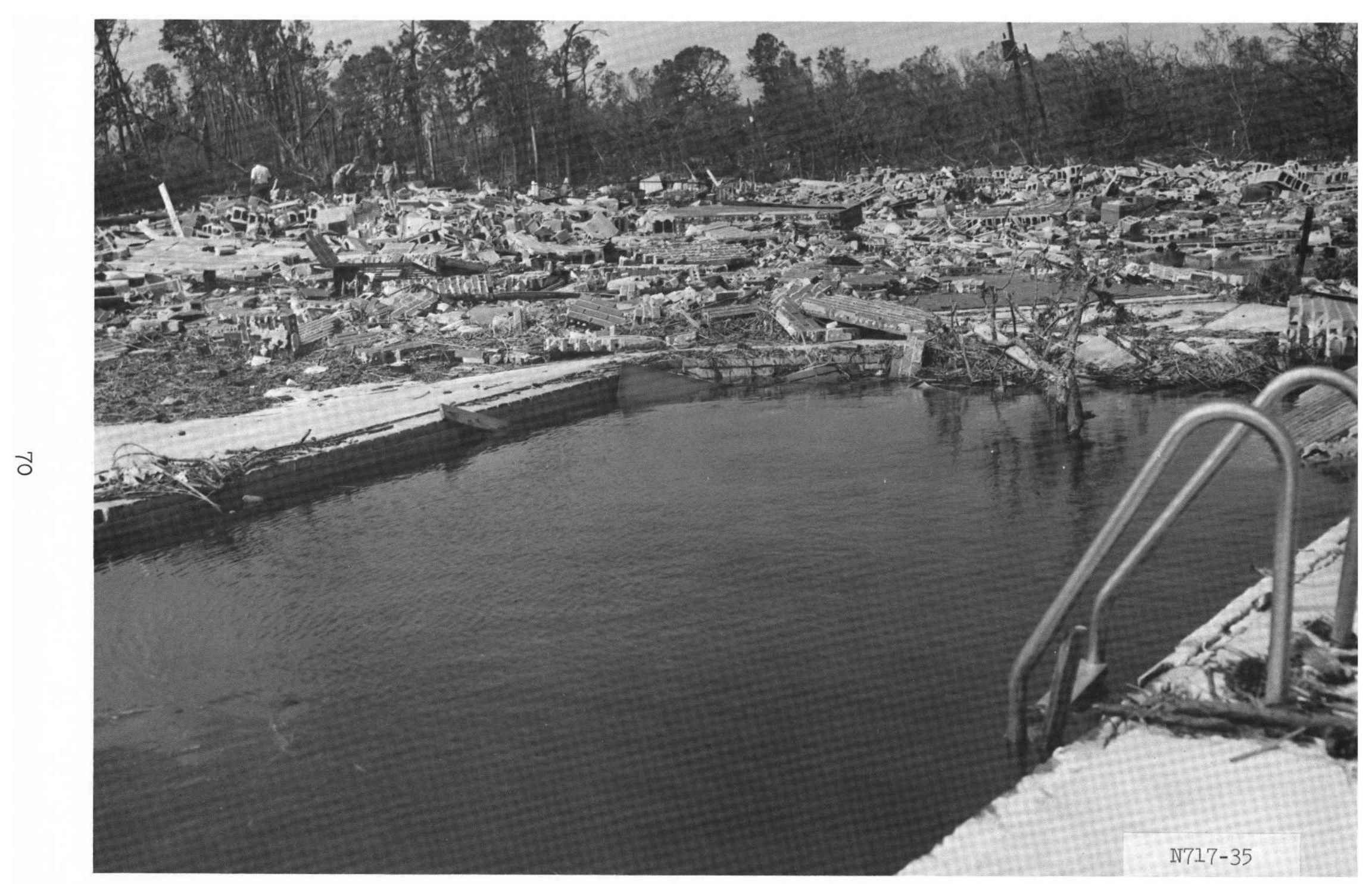

Figure 2.44 Pool area, Gulf Villa Apartments, Long Beach area. 


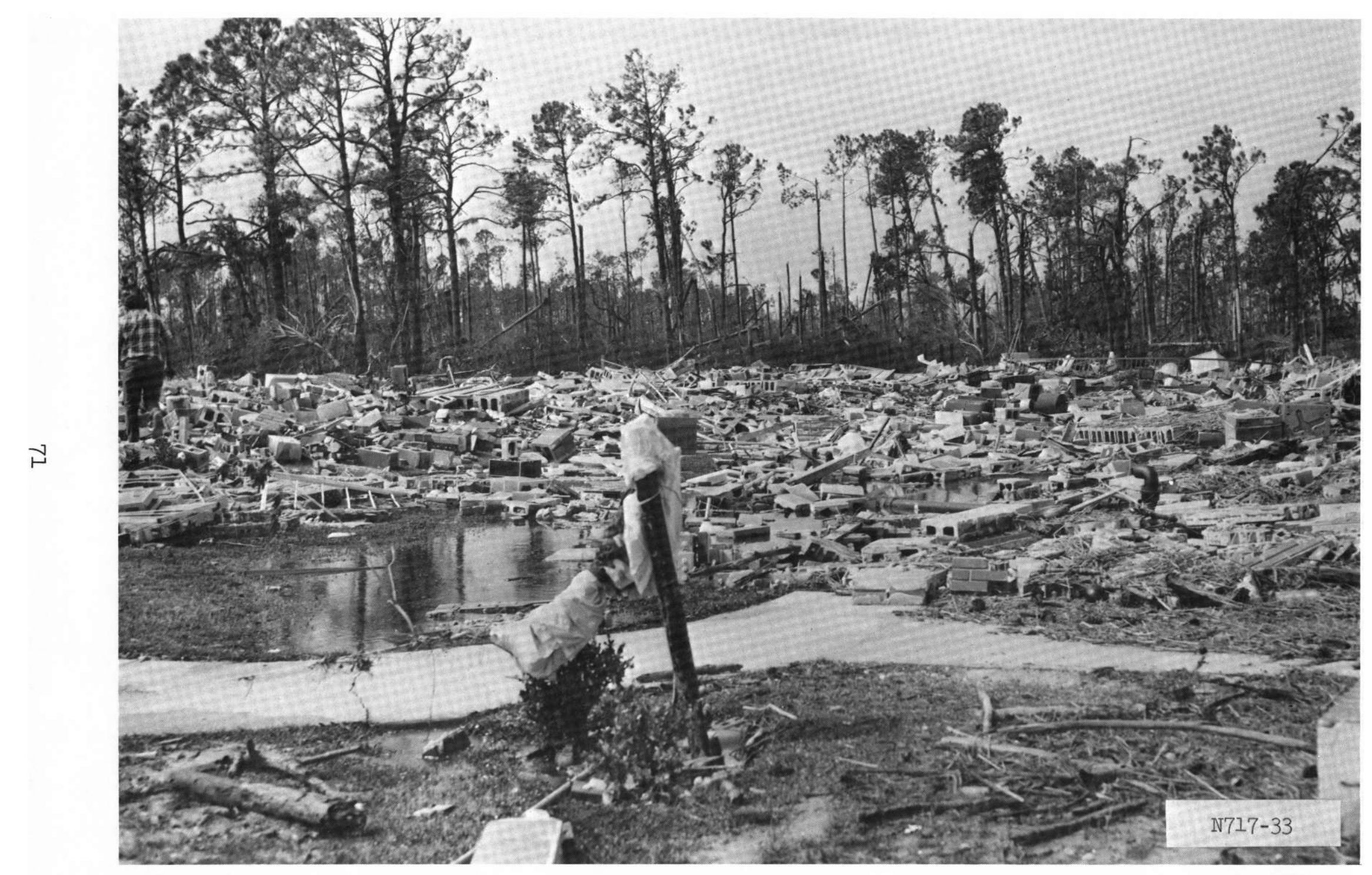

Figure 2.45 Gulf Villa Apartments, Long Beach area. 


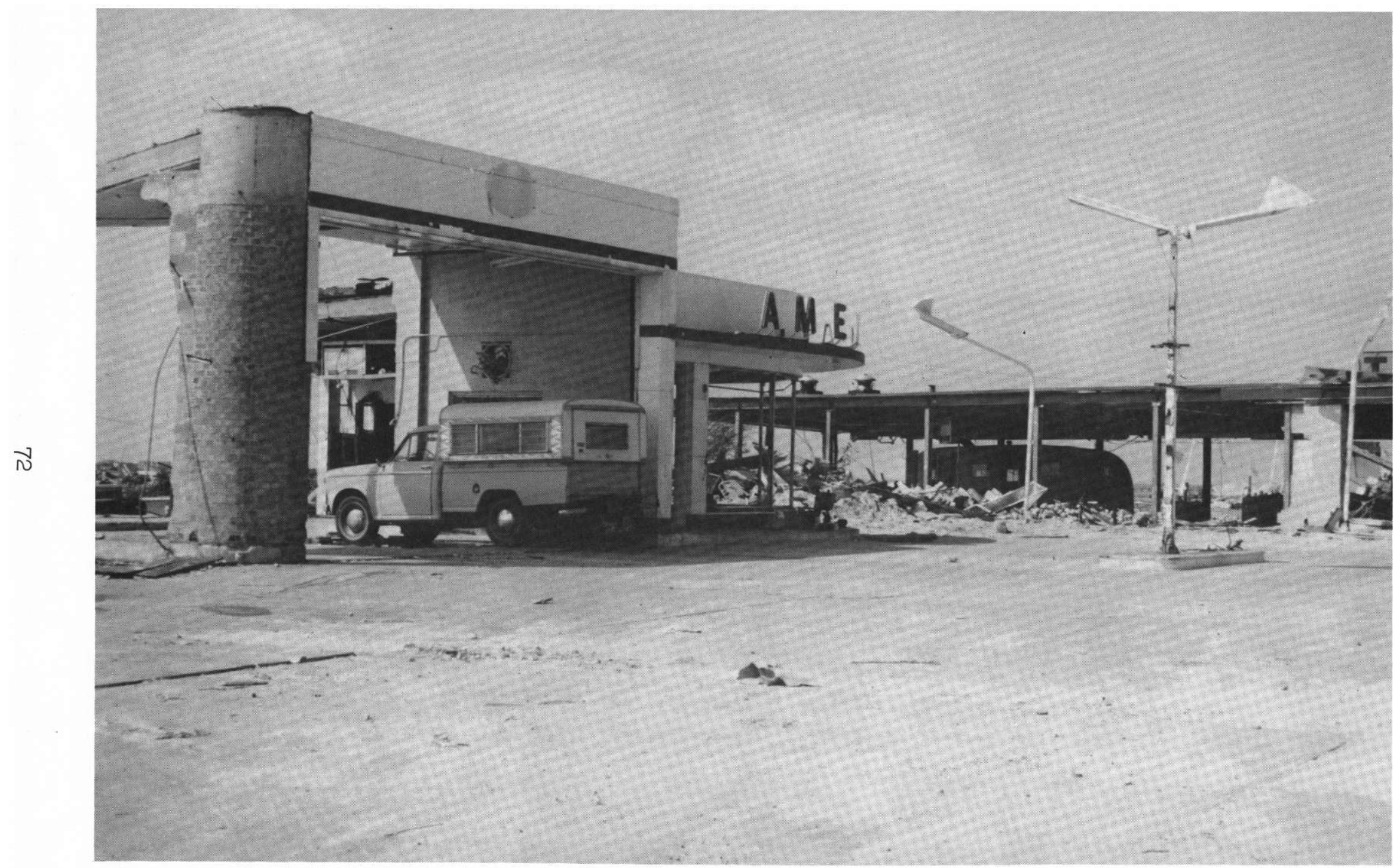

Figure 2.46 Service station, west Gulfport area. 


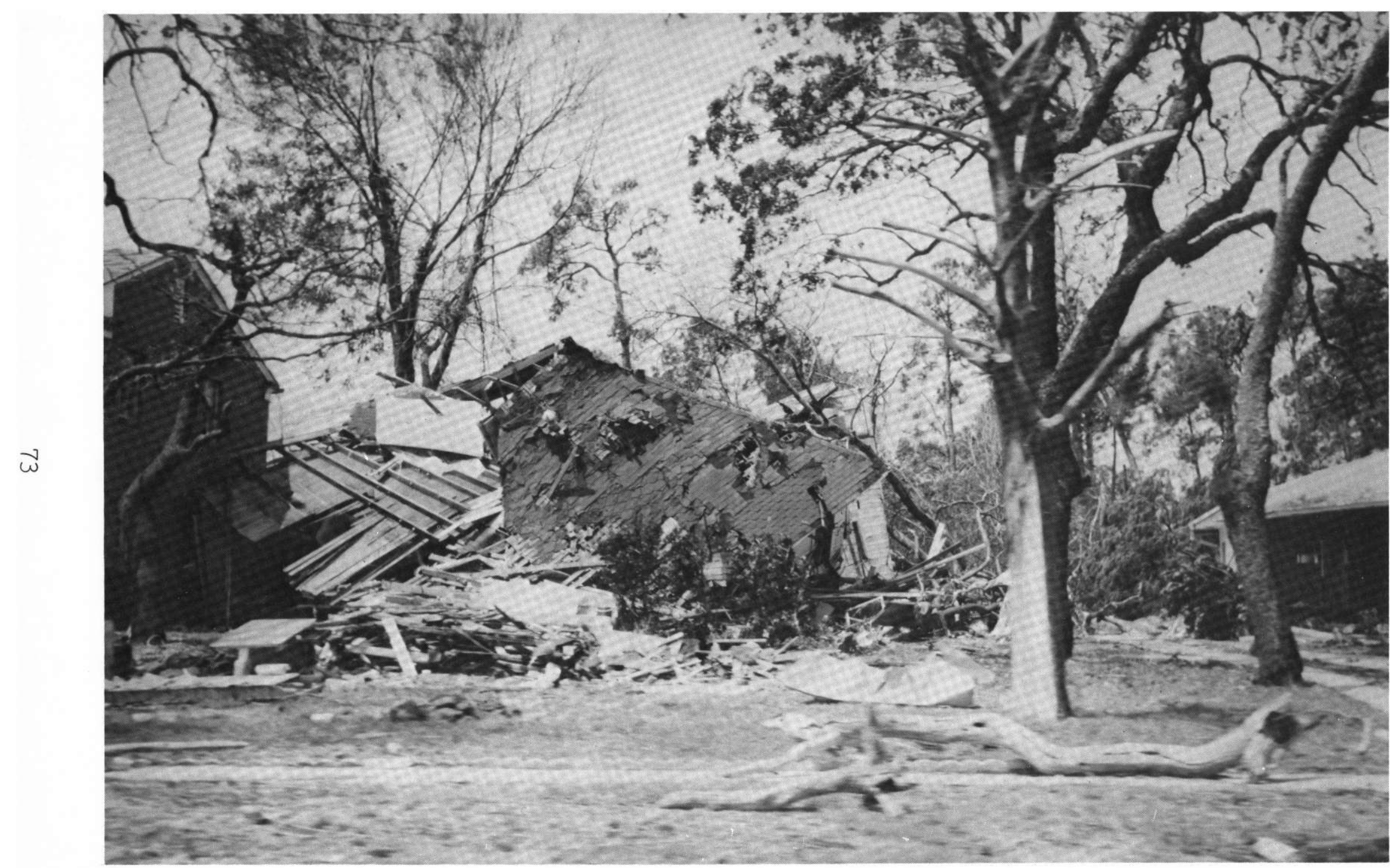

Figure 2.47 Collapsed frame house, between Biloxi and Gulfport, Mississippi. 


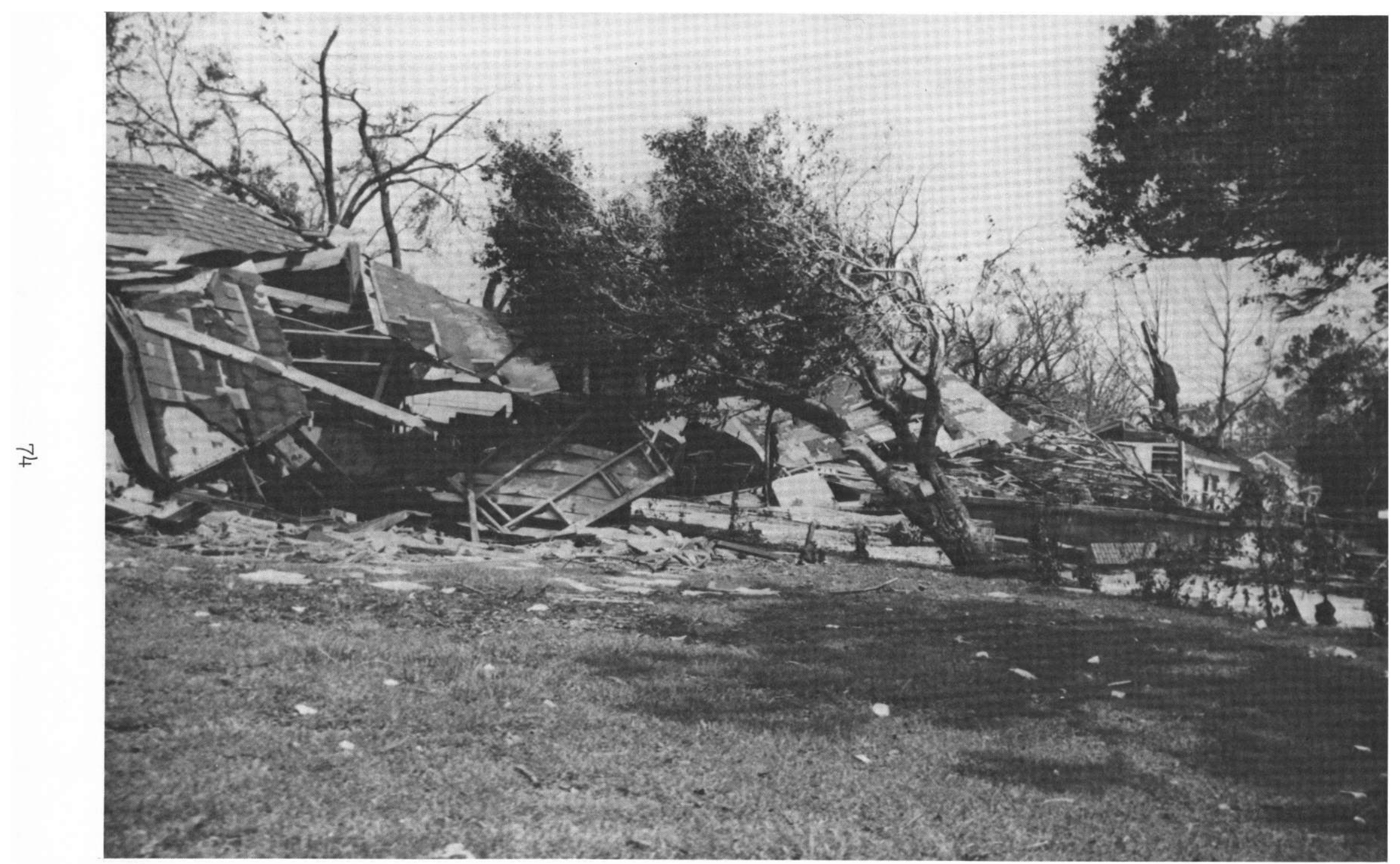

Figure 2.48 Collapsed frame house, Long Beach area. 


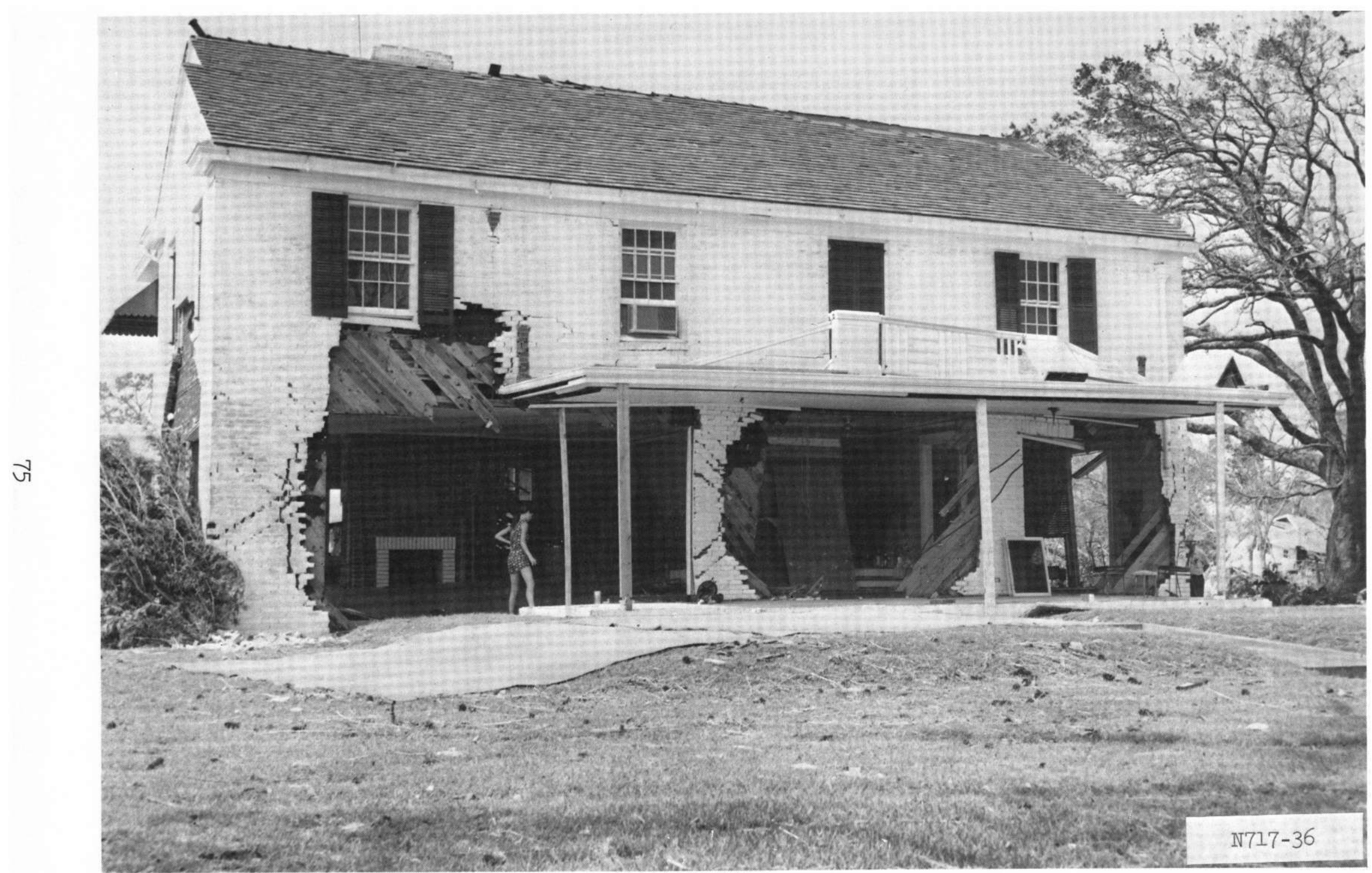

Figure 2.49 Residence, Long Beach, Mississippi. 


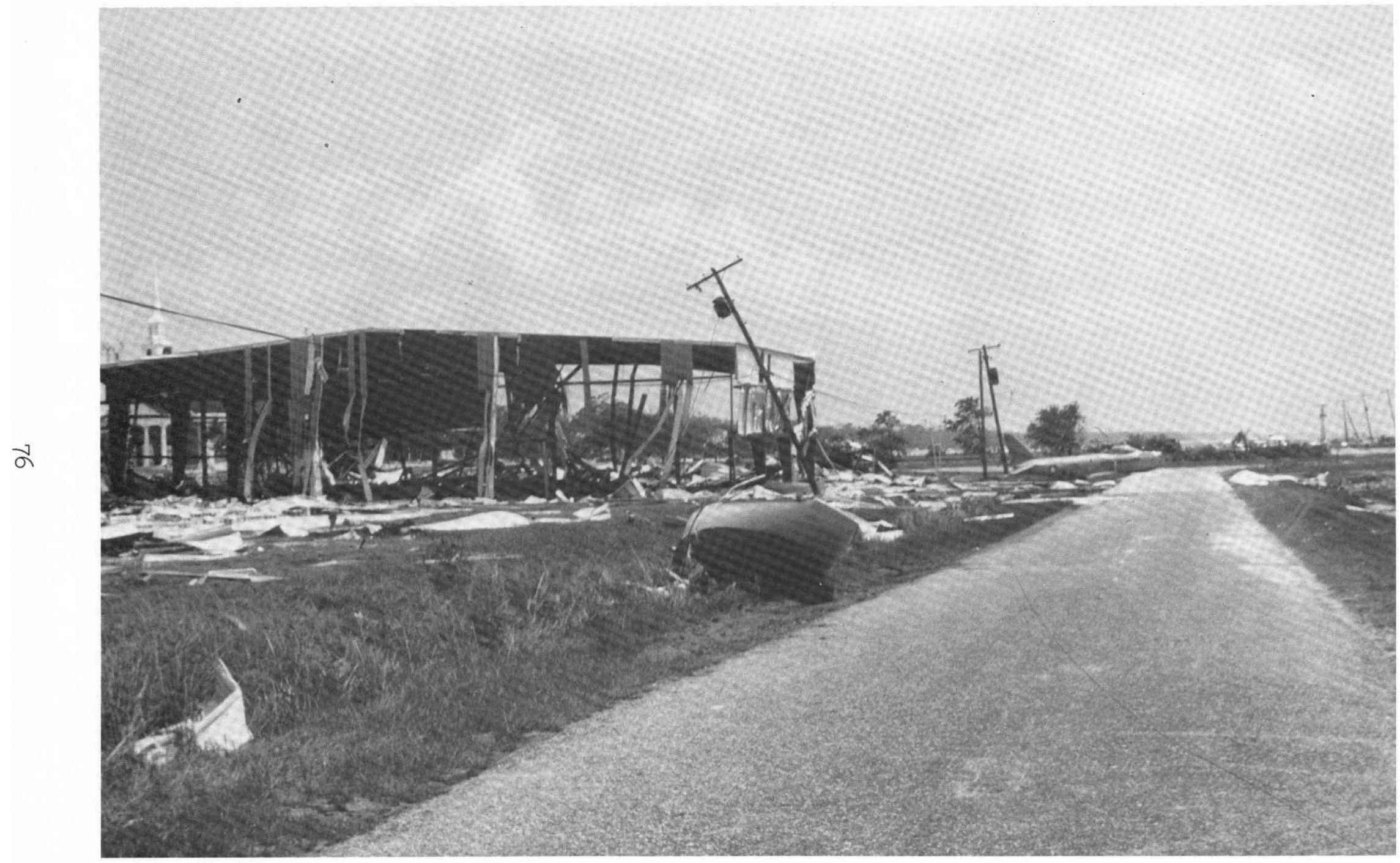

Figure 2.50 Steel frame recreation hall, Jones Memorial Park, Gulfport. 


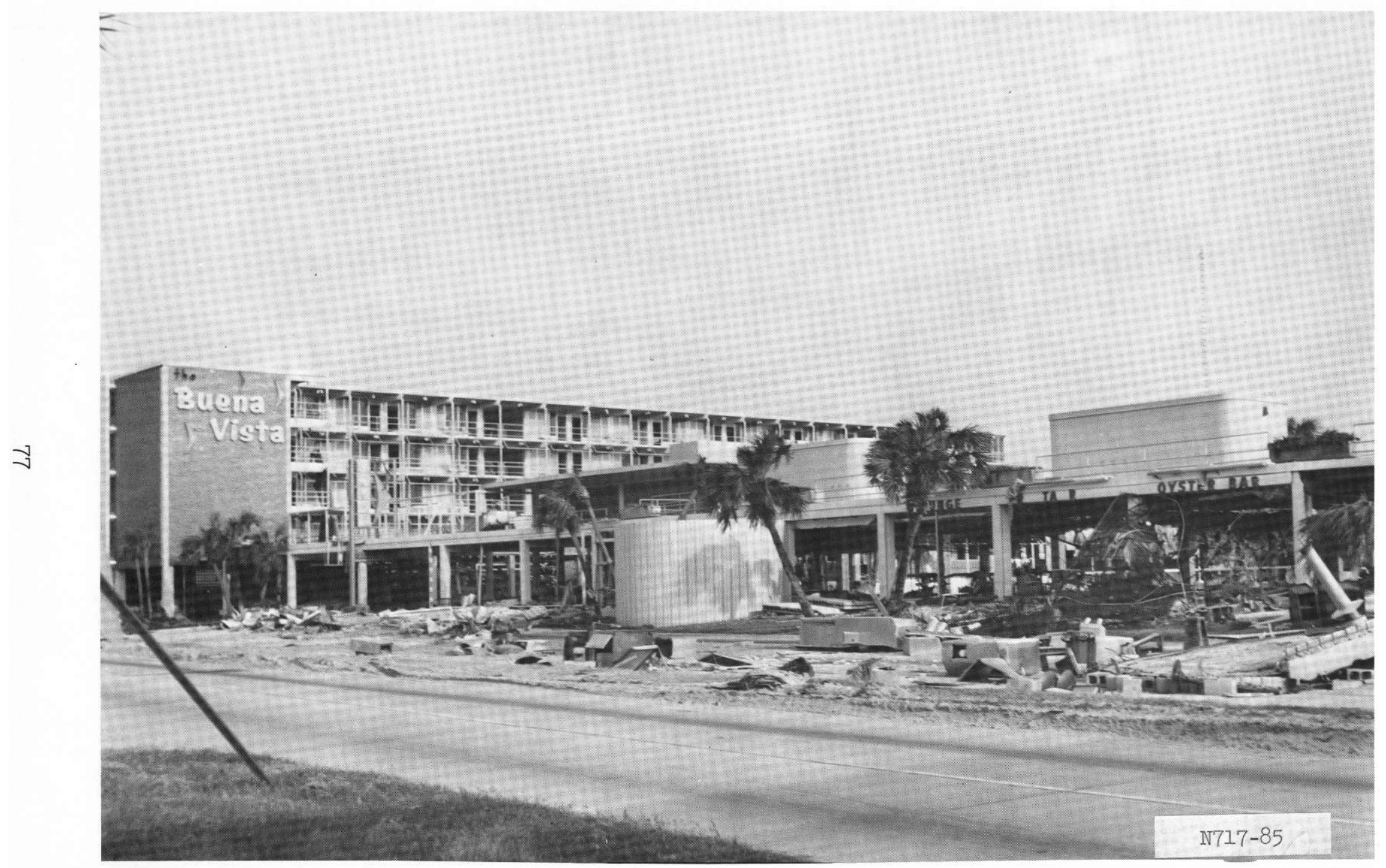

Figure 2.51 Frame restaurant structure, Biloxi, Mississippi. 


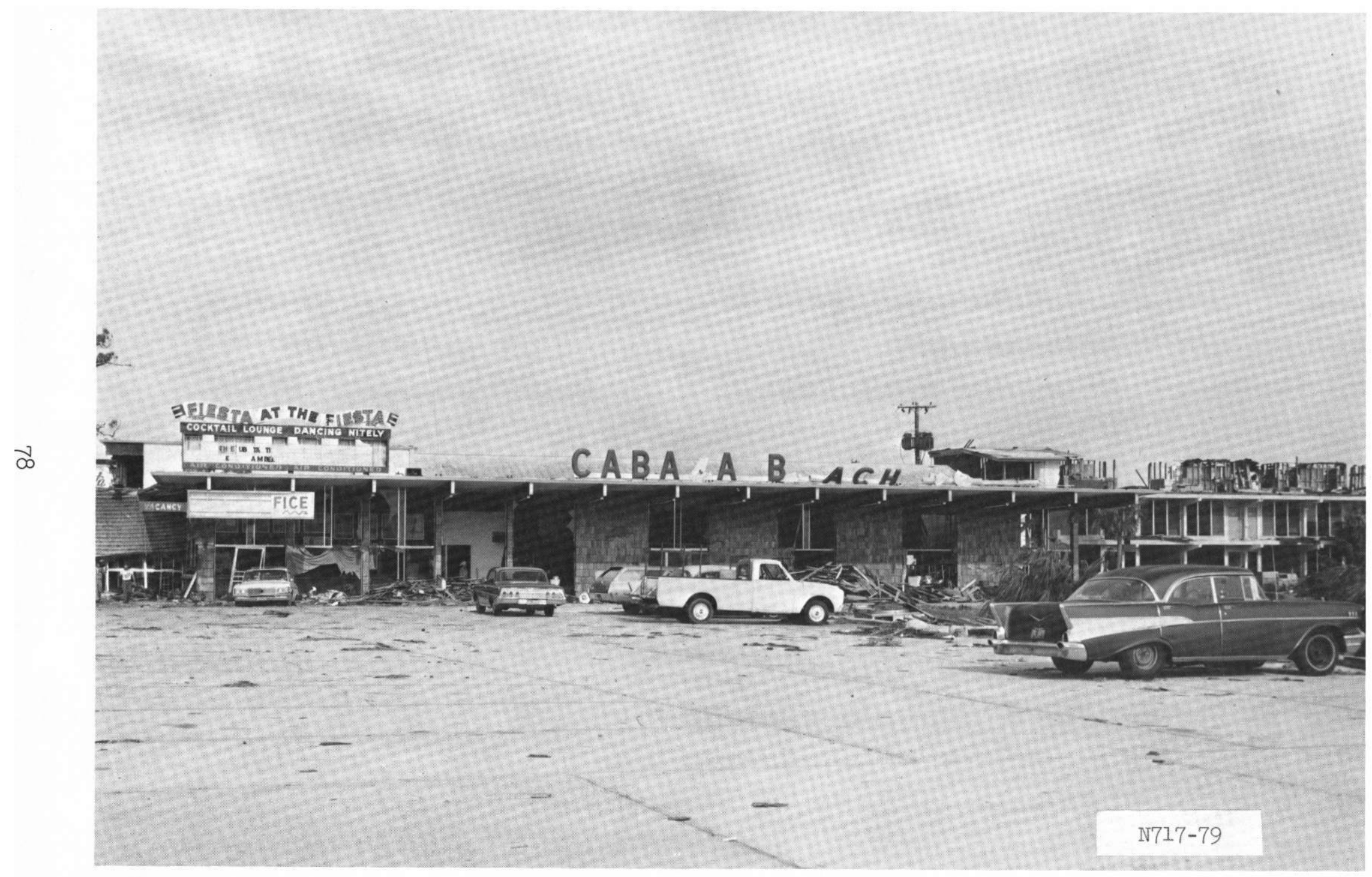

Figure 2.52 Frame motel structure, Biloxi, Mississippi. There had been fire damage before the storm to the building shown at the right. 


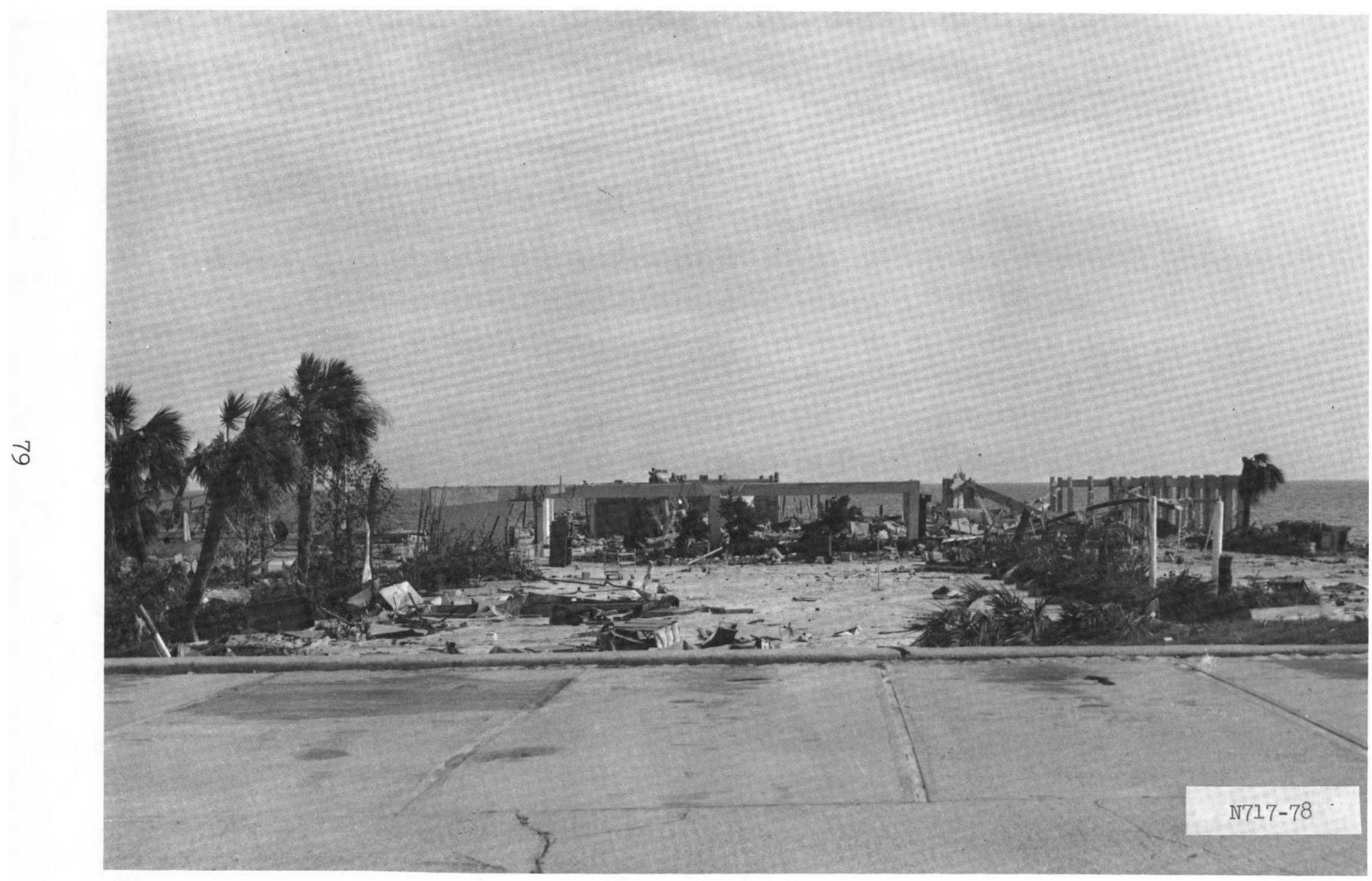

Figure 2.53 Concrete frame restaurant, Biloxi, Mississippi. 


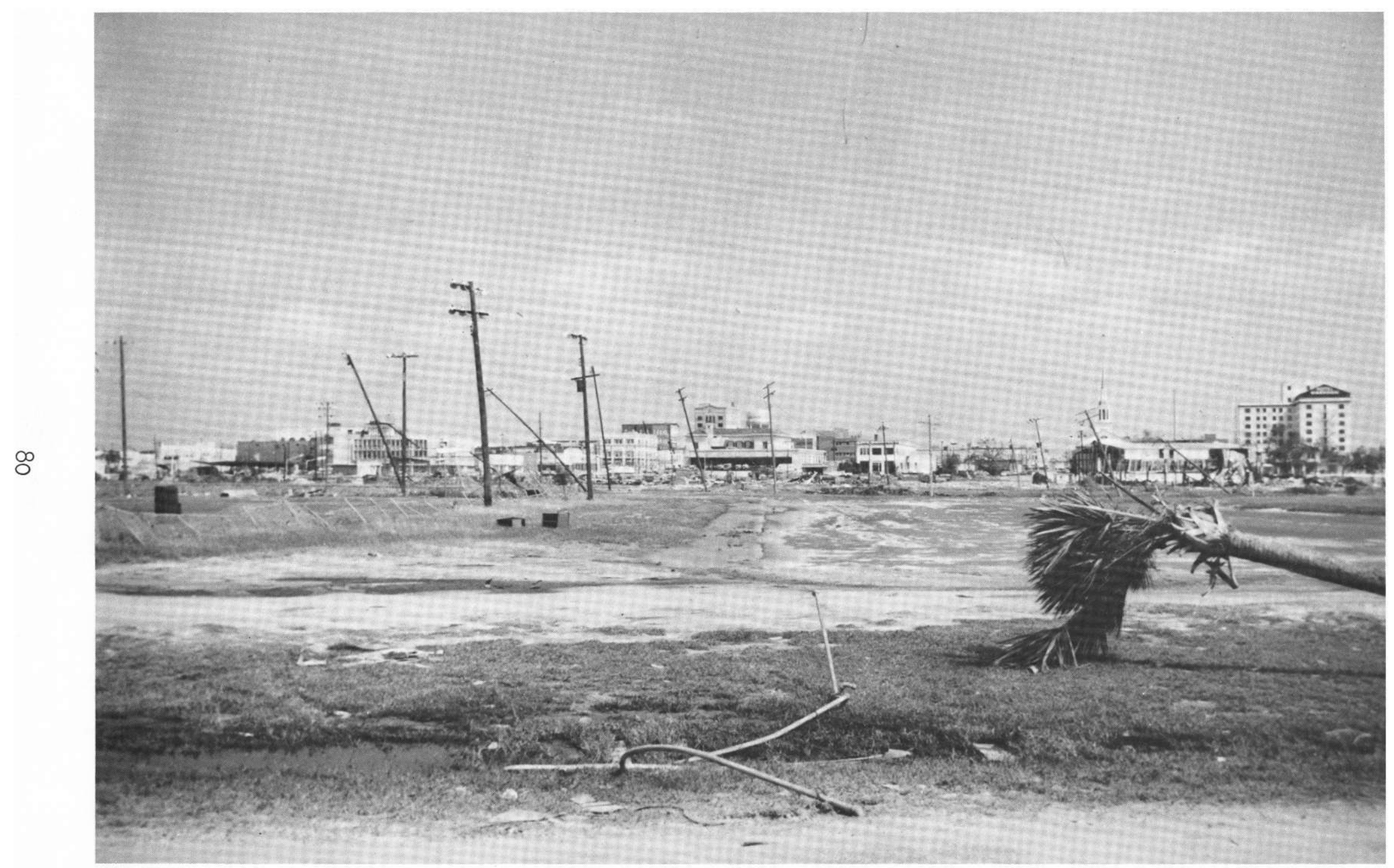

Figure 2.54 Gulfport business district from the south. 


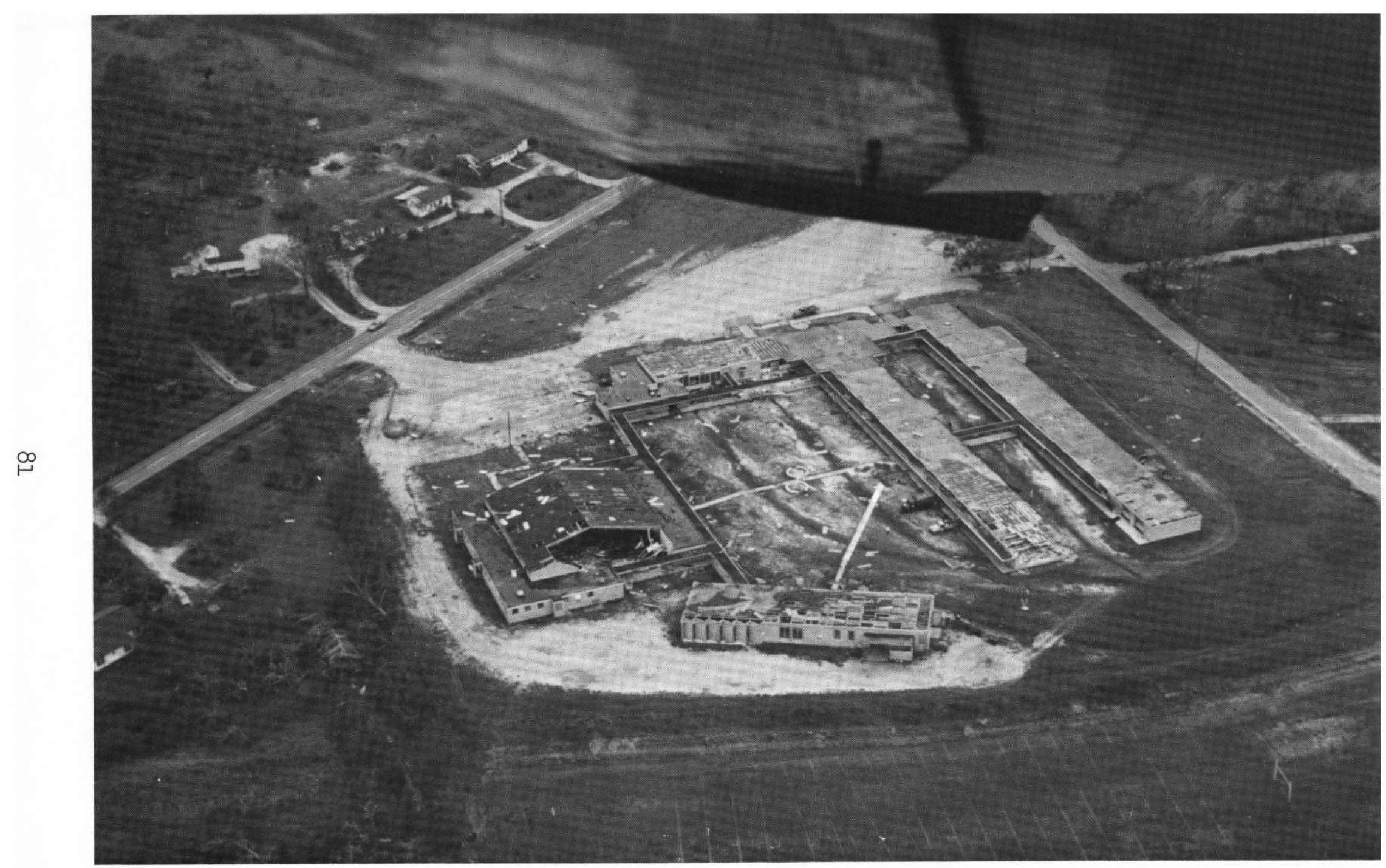

Figure 2.55 Poplarville High School, Poplarville, Mississippi. 


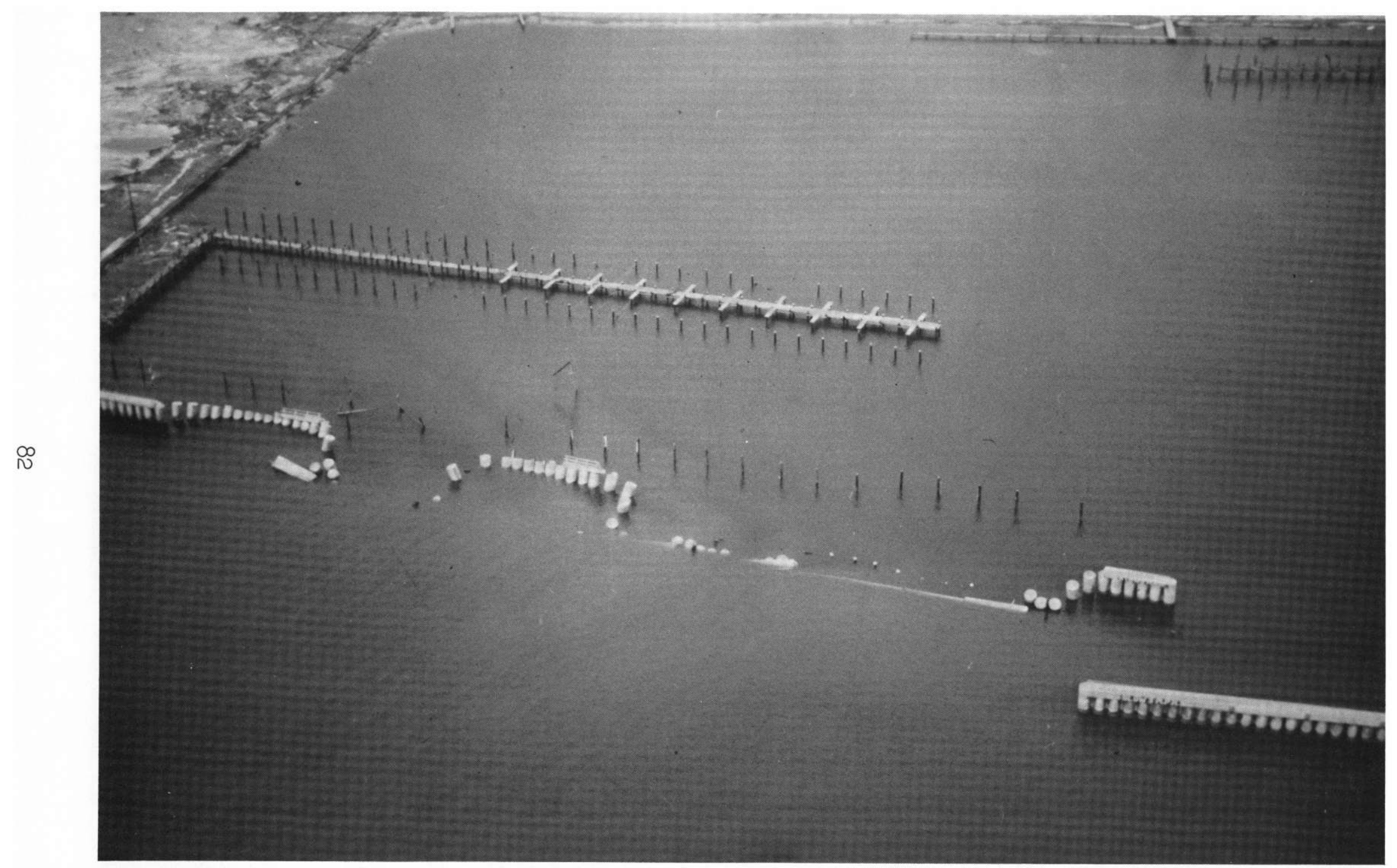

Figure 2.56 Pass Christian small-boat harbor, Pass Christian, Mississippi. 
CHAPTER 3

CASE STUDIES OF STRUCTURAL DAMAGE

Several nonresidential structures were more closely examined and the damage to them will be reported in this Chapter in more detail.

Most structures chosen for more detailed study were significantly damaged but not totally collapsed. This excluded most masonry construction along the coast and other structures so totally destroyed as to make a meaningful examination difficult or impossible and most larger buildings inland where any damage was usually minor and probably hidden by nonstructural elements of the building.

\subsection{STATE DOCK}

This building is a large clear span (span of about 125 feet) warehouse located at the southern tip of the Port of Gulfport. It is of rigid-frame construction with combination columns (steel sections encased in structural concrete) and with tilt-up concrete wall panels about 20 feet square by 6 inches thick and roll-up doors forming the walls. Light sheet metal pur lins run along the length of the building and support a sheet metal roof. The columns appeared to have been cast in two steps, one to encase the steel section and the second to key in the tilt-up walls. The general construction is shown in Figures 3.1 and 3.2 .

As shown in Figures 3.3 through 3.5 , the end facing south-southeast and the first bent collapsed into the building with the tilt-up panels of this end wall falling with the colums. The tilt-up panels along the east side of the building were pushed into the structure, and those along the west side fell away from the structure. Like many other structures along the coast, this building was subjected to loadings far above those probably anticipated in their design.

The connections at the base of the columns along the collapsed end wall failed. The dowels at the corner columns, shown in Figures 3.6 and 3.7 , were very short, of small size, and had pulled out without breaking. The dowels in other columns along the end wall were larger and longer but still not adequate to develop the tensile strength of the dowel (Figure 3.8). 
Dowels in at least one column were placed outside of the reinforcing cage and were able to break out of the colum without even bending (Figure 3.9). Cold joints were found at the base of some columns. Only one broken reinforcing bar was seen at the colum bases along the collapsed end wall.

The end wall probably received only small lateral support along its top from the small roof purlins and effectively functioned as a large slab simply supported at both ends and along the bottom. This structure could not resist the extremaly large lateral loadings from the storm, probably failed first near the top center, and fell into the building.

One large (No. 9 or 10) bar contained on the horizontal beam over the tilt-up panels of the end wall ruptured with little ductility being displayed at the location of a bend (Figure 3.10).

The Port buildings contain 30,000 low protection factor (a PF of less than 40) NFSS shelter spaces. The number assigned to the State Dock, if any, was not determined.

other Port buildings were either metal-clad rigid-frame buildings, which lost almost all of the sheeting on the walls, or older reinforced concrete rigid-frame buildings located on the leeward side of the Port and which suffered only minor structural damage, even though much of their contents were washed out. Some of the metal-clad buildings are visible in Figure 3.11 and in the background of Figures 3.13 and 3.17 .

\subsection{MARINE LIFE AQUARIUM}

Marine Life consisted of a group of various stmuctures (Figure 3.12). A large steel arch which this team was told was designed for 120-mph winds sheltered a display tank and a concrete seating area. A small (30 to 50 spaces) NFSS shelter was located under this seating area. A concrete floor and block wall structure surrounded the large display tank to the east of the arch.

The steel arch remained standing despite the loss of two pipe column supports at the northeast corner (corner nearest the camera and to the left in Figure 3.13) and the dropping of the other three columns on the east side. Some roofing was torn off the west side of the arch (Figure 3.14). The middle pier supporting the west end of the arch was badly damaged 
(Figure 3.15) and no doubt would have functioned better had more colum ties been included near the top of the pier.

The approximate maximum water wave level during Hurricane Camille is the top of the bent cladding on the arch (see Figure 3.16).

The block wall along the west side of the arch was almost completely destroyed (Figure 3.17).

The seating over the NFSS area rested directly upon five concrete block walls (mostly unfilled and containing small amounts of block ties) and consisted of 8 - by 10-inch beams forming the front of the steps with a thin slab reinforced with welded-wire fabric for the tread portion. The beams contained four No. 6 bars, one on each corner, and stirrups on about 18-inch centers. The bars were lapped 6 inches or more. over the block walls.

This seating area under the east side of the arch was completely collapsed (Figures 3.18 and 3.19). The seating area appeared to have failed when the water lifted the seating and dropped it onto the walls crushing some block and failing the beams of the seating portion at the supporting walls, thus transforming the beams into essentially simply supported spans which then fell (Figures 3.20 through 3.22). It was not clear whether these beams had been designed for continuity; the steel arrangement, but not the splice length, suggests that they were.

The welded-wire fabric of the seating slab tore out of the beams easily and had little or no cover, as can be seen in the beam shown in the foreground of Figure 3.20 and in Figure 3.23, which shows a beam that ultimately failed in torsion.

The structure around the large tank was in ruins (Figure 3.24). Several cases of extreme corrosion of the reinforcement were seen. Two examples of such corrosion can be seen in Figures 3.25 and 3.26; this corrosion is somewhat surprising since both the beam and the slab shown had $1-1 / 2$ inches of cover. Although the tanks contained water, conditions at these beams and slabs should not have been more severe than those for many coastal structures.

A bundle of No. 6 bars was found by the arch, raising the question of whether it was extra or had been left out of something somewhere. 
An 8-foot-high block wall immediately north of the arch had been pushed over intact (Figure 3.27). This wall had been tied down with one No. 6 bar at 12-foot centers.

\subsection{MARINE SHOP}

A small marine retail store and shop located in a steel-frame building directly south of Marine Iife was totally destroyed. This building, consisting of four 12-foot-wide bays of 36-foot span, was directly in the path of numerous small boats (up to 50 feet) which broke from their moorings and moved through the area.

The steel frame ended up in a pile west-northwest of the building slab (Figure 3.28) with one colum still tied to the slab (Figure 3.29). The welds at the base plate of another column failed (Figure 3.30).

The weld between the flange and web of a 12 -inch fabricated plate girder failed, as shown in Figure 3.31. This was a consequence, not a cause, of failure.

\subsection{PASS CHRISTIAN CITY HALL}

This building, shown in Figure 3.32, is a two-and-one-half-story building with a heavy wooden frame (2-inch dimension lumber on close spacing) and a brick exterior, located in the heart of Pass Christian. After Camille, it was the only building remaining on the south side of Pass Christian's main street for more than two blocks in either direction. Most other buildings in the area appeared to be light, long span, wooden commercial buildings typical of many older and small town business districts (Figures 3.33 through 3.35).

The City Hall appeared to have suffered little, if any, structural damage. The building had swayed enough during the storm to crack plaster (Figure 3.36), some windows were broken, and water was at least 5 feet deep in the first floor above the basement.

An OCD Emergency Operating Center (EOC) was located in the basement on the seaward side of the building. The poststorm condition of this room is shown in Figure 3.37 . 


\subsection{RAMADA INN}

The inspection team was told that this motel complex in Long Beach was designed to be hurricaneproof. It actually performed quite well compared to the structures around it.

The main building (Figure 3.38) was parallel to the highway. There appeared to be two wings perpendicular to and behind the main building. The east wing was completely leveled and the west wing was relatively undamaged. The east wall of the main building was out (Figure 3.39), and the entire first floor suffered extensive water damage, especially in the dining area (Figure 3.40 ).

\subsection{A\&P AND ADJOINING SHOPPING COMPLEX}

This complex, located several blocks east of the Ramada Inn in Long Beach, was constructed mainly of block walls, steel pipe colums and main beams, and with small angle trusses or bar joists supporting the roof. The front of the A\&P store is shown in Figure 3.41.

A Walgreen's store located on the seaward side of the A\&P collapsed completely with much debris ending up in or behind the A\&P (Figure 3.42). The angle trusses appeared to have been set into the block and brick exterior walls and fell with the wall. Small bulb angles placed atop the trusses and supporting the roofing panels spaced the trusses laterally.

The two side bays of the A\&P store collapsed, probably when the walls between this building and the adjoining stores were destroyed. One corner of the wooden truss hip roof at the front of the A\&P was left cantilevered

over the debris (Figure 3.43). The center bay, supported on steel beams at both ends, did not suffer extensive structural damage (Figure 3.44). The presence of lamps in the fixtures shows that the water did not reach the ceiling level.

The center row of beams and columns of the Morgan and Lindsey variety store directly north of the A\&P survived with most of the roof trusses remaining connected to the beams (Figure 3.45). The other ends sat on masonry walls which collapsed.

In this complex of stores, two pipe columns in which bolt holes 
did not line up with those in the beams above had simply been tack welded, which indicates that some of the workmanship was questionable. Most of the 24-inch-deep trusses were connected to the beams with small welds about 2 inches long.

\subsection{GULF PLAZA}

Several stores, including a large discount-type store, were located in Gulf Plaza near the Long Beach-Pass Christian boundary and contained in a large pipe colum, beam, and bar joist structure with glass and block walls. As can be seen in Figures 3.46 and 3.47, the exterior walls and store contents were completely washed away, leaving only portions of the building frame. It appeared that only a minimum amount of welding had been used to attach the bar joists to the-supporting beams.

An apartment complex located east of the shopping area was completely leveled, with most of the floor slab cleared of debris by the storm (Figure 2.19).

\subsection{BROADWATER BEACH BOAT MARINA}

This sizable small-boat marina, located near the west end of Biloxi, consisted of cast-in-place concrete columns and precast arches (double T sections attached to large concrete "bow" sections). This structure was specifically designed for heavy hurricane loading and therefore is not a typical structure.

The connections and details of the marina appeared to be very well designed and constructed. Some colums showed a flexural failure near the base with no hint of connection failure. The welds joining the anchor plates of the precast elements appeared to be generally as strong as the elements themselves.

Some of the double $T$ sections were damaged when the arches rocked back and forth (Figure 3.48) with differential motion occurring at the valley where two arches met.

The two north corners of the marina were destroyed (Figures 3.49 and 3.50), very possibly by boats coming through these parts of the marina.

The presence of a large sailboat high above the water and against the 
office area (Figure 3.51) indicates a lower bound on the water height in this area.

\subsection{BAY SAINT IOUIS BRIDGE}

This four-lane multispan causeway crosses from Pass Christian to Bay Saint Louis. Precast deck slabs, two lanes wide and supported on pile bents, form the bridge.

The water appeared to have lifted the seaward deck slabs up enough for the rocker bearings on the east end of each span to fall out, resulting in a sawtooth appearance along the south side of the bridge (Figures 3.52 and 3.53). Some of the railing sections were tilted inland, and all but one lamp was torn from its pole. One span was moved about 4 feet laterally (Figure 3.54). Considerable concrete was spalled along the bridge centerline where the two deck slabs joined. The west abutment was heavily damaged by wave action (Figure 3.55 ).

More extensive damage was reported for a similar bridge east of Biloxi; this bridge was not visited by the survey team. 


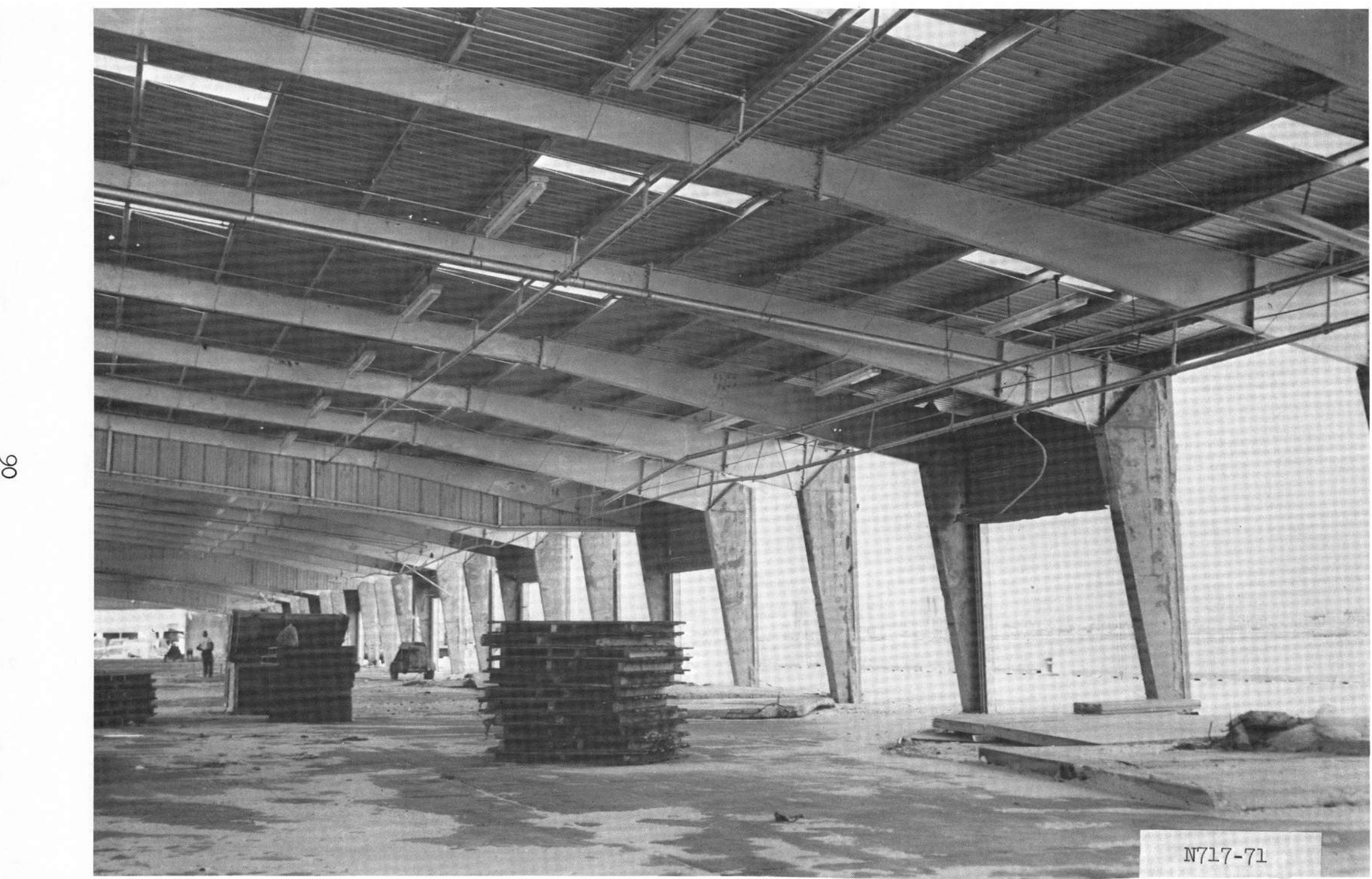

Figure 3.1 Close-up view of general construction of State Dock. 


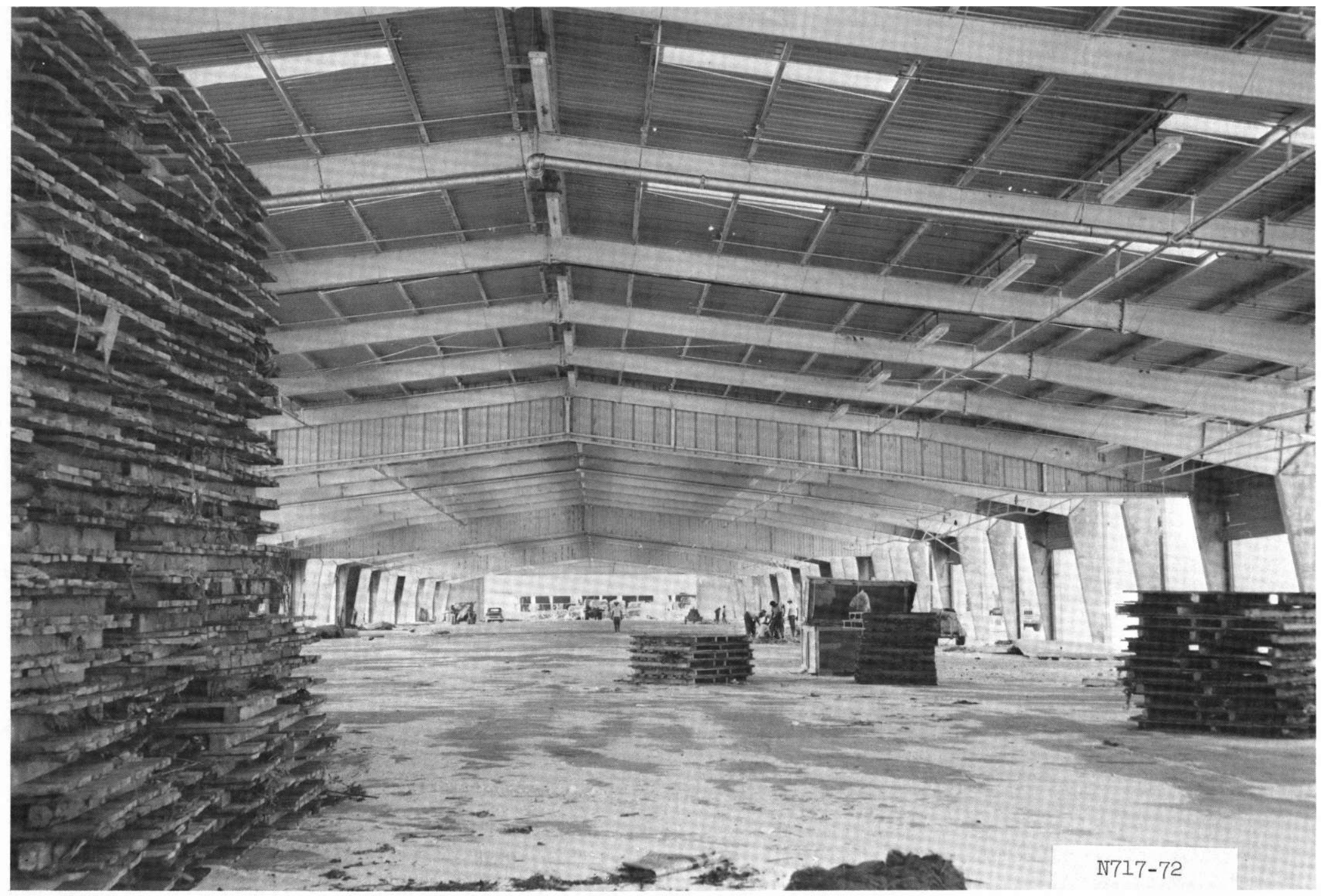

Figure 3.2 General view of State Dock. 


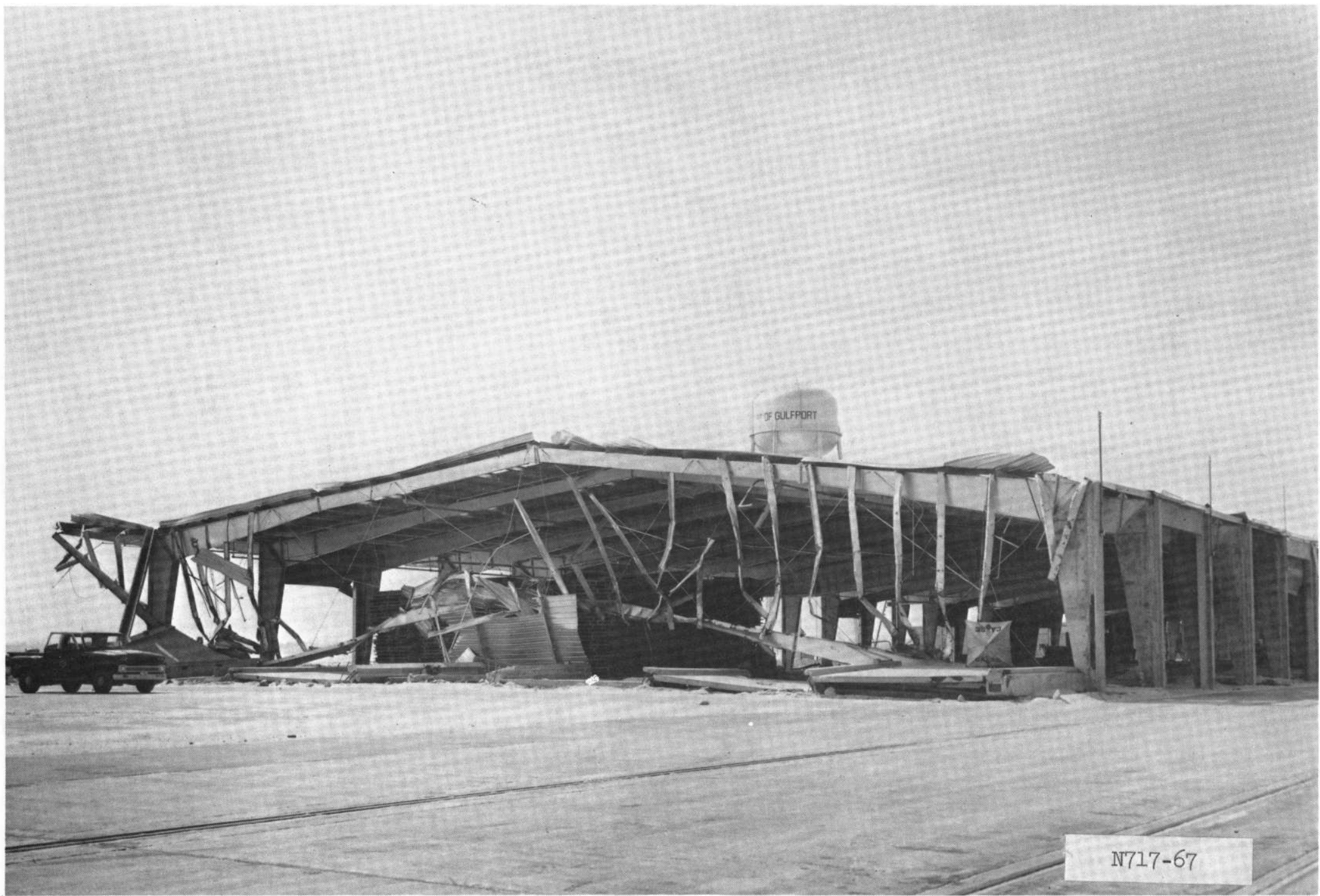

Figure 3.3 Collapsed end wall of State Dock. 


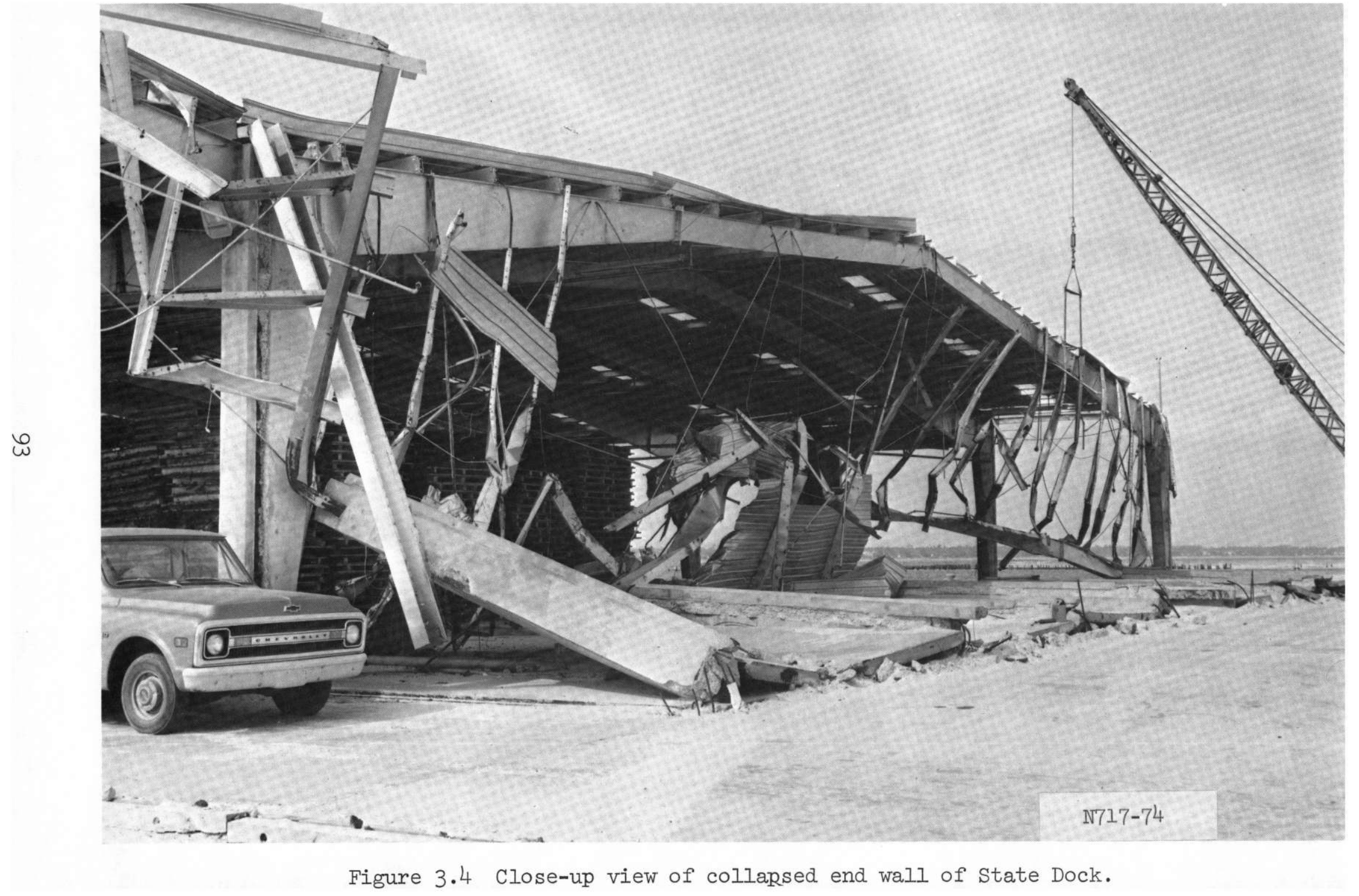




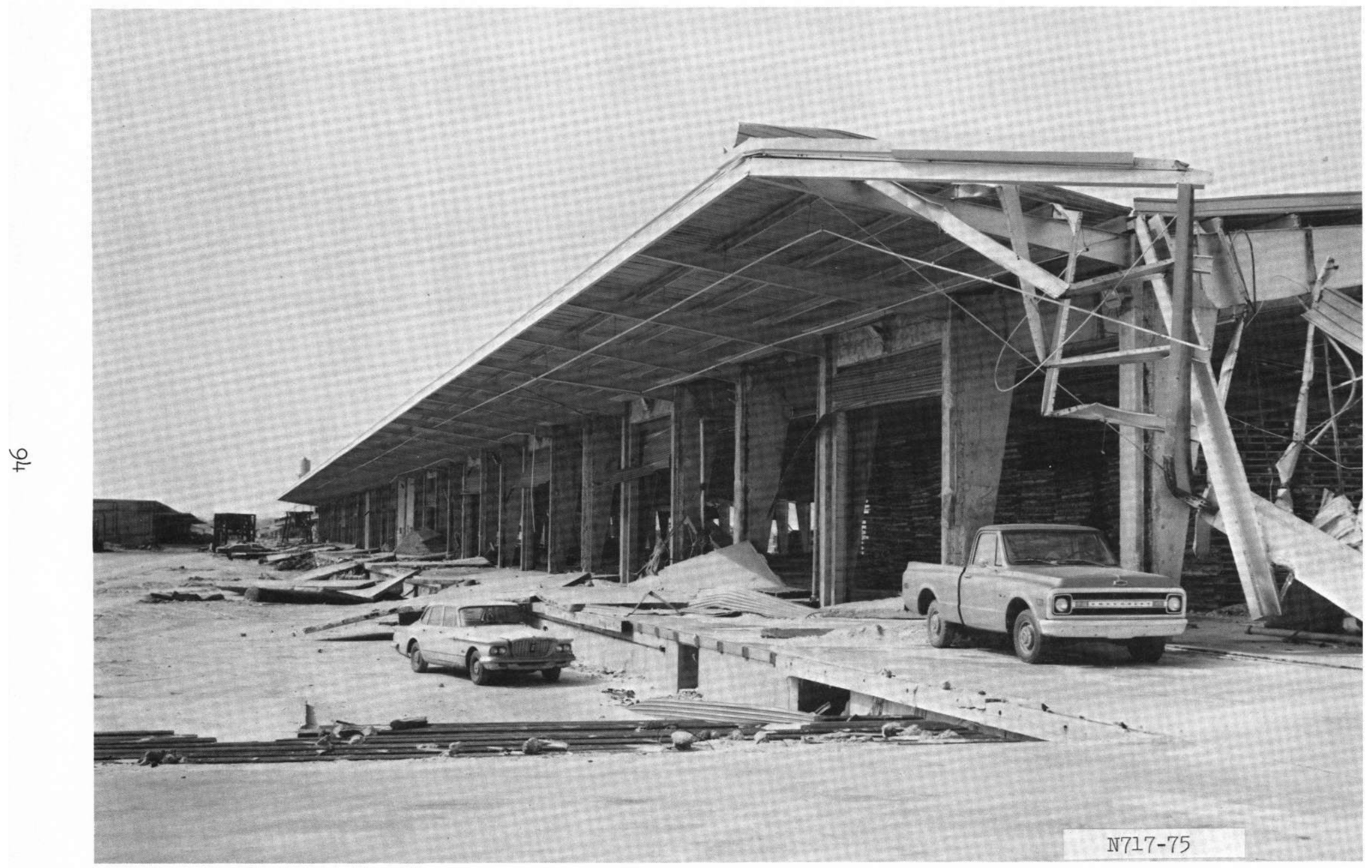

Figure 3.5 Failure of tilt-up walls along west side of State Dock. 


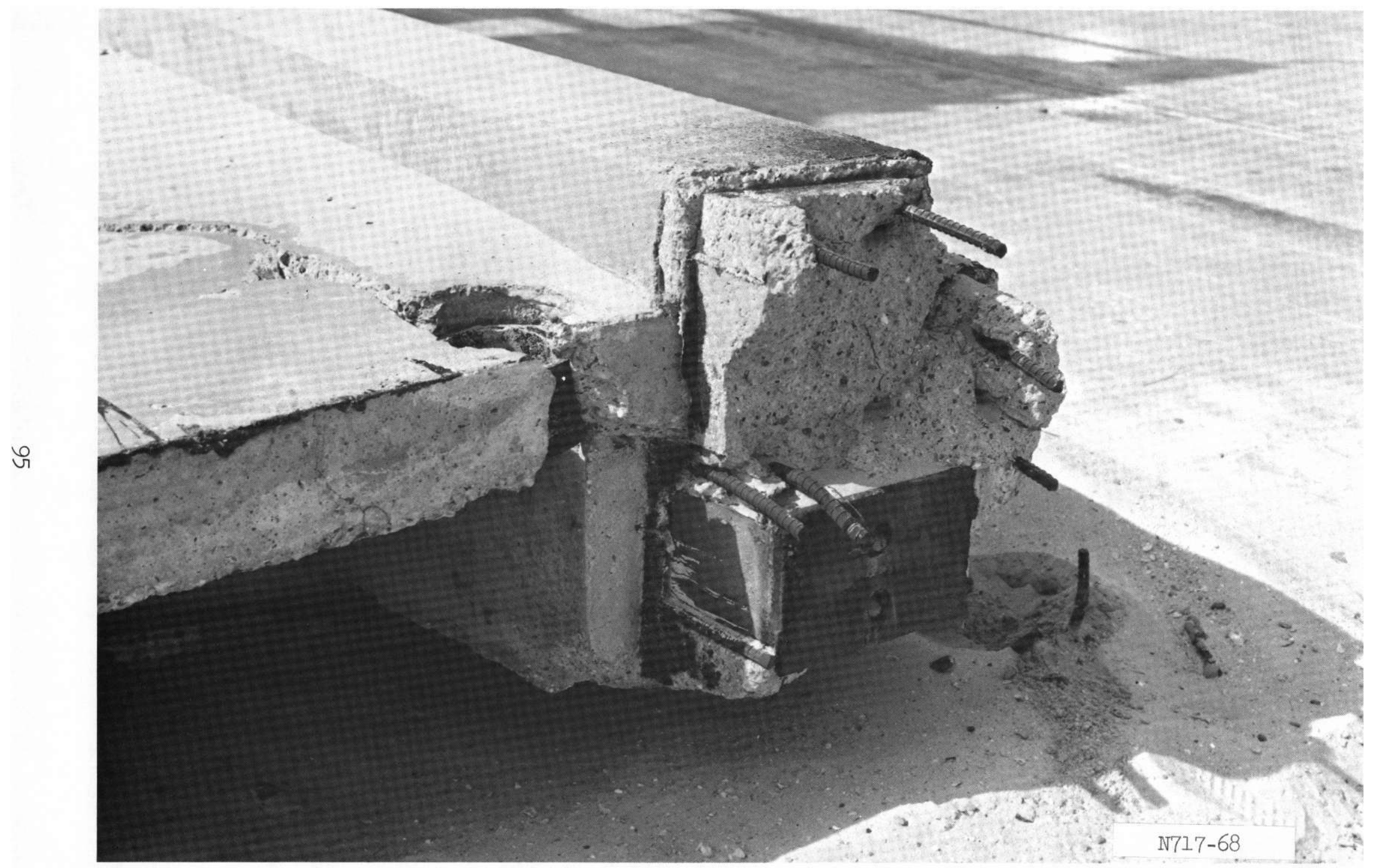

Figure 3.6 Southeast corner column, State Dock. 


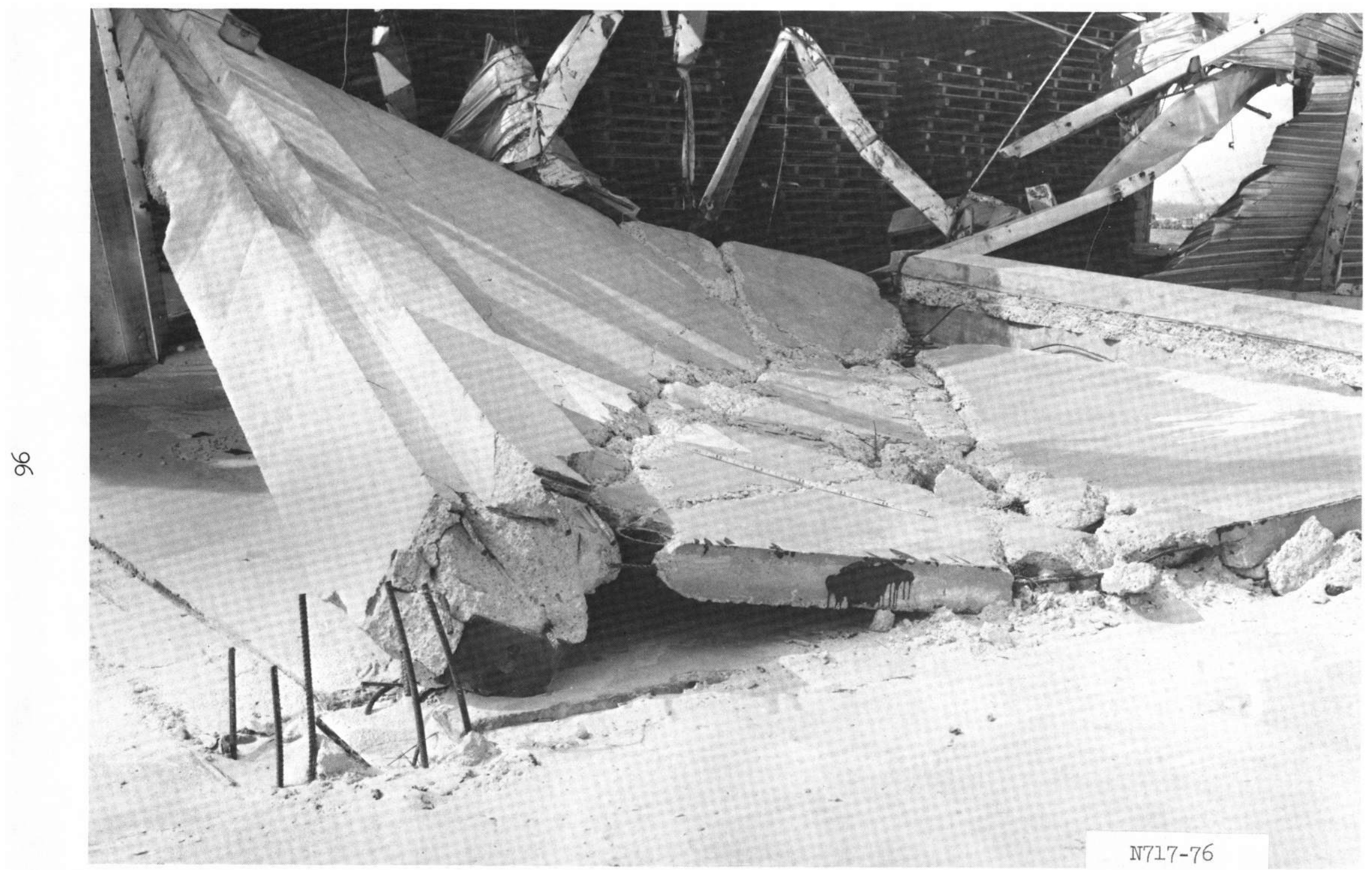

Figure 3.7 Southwest corner column, State Dock. 


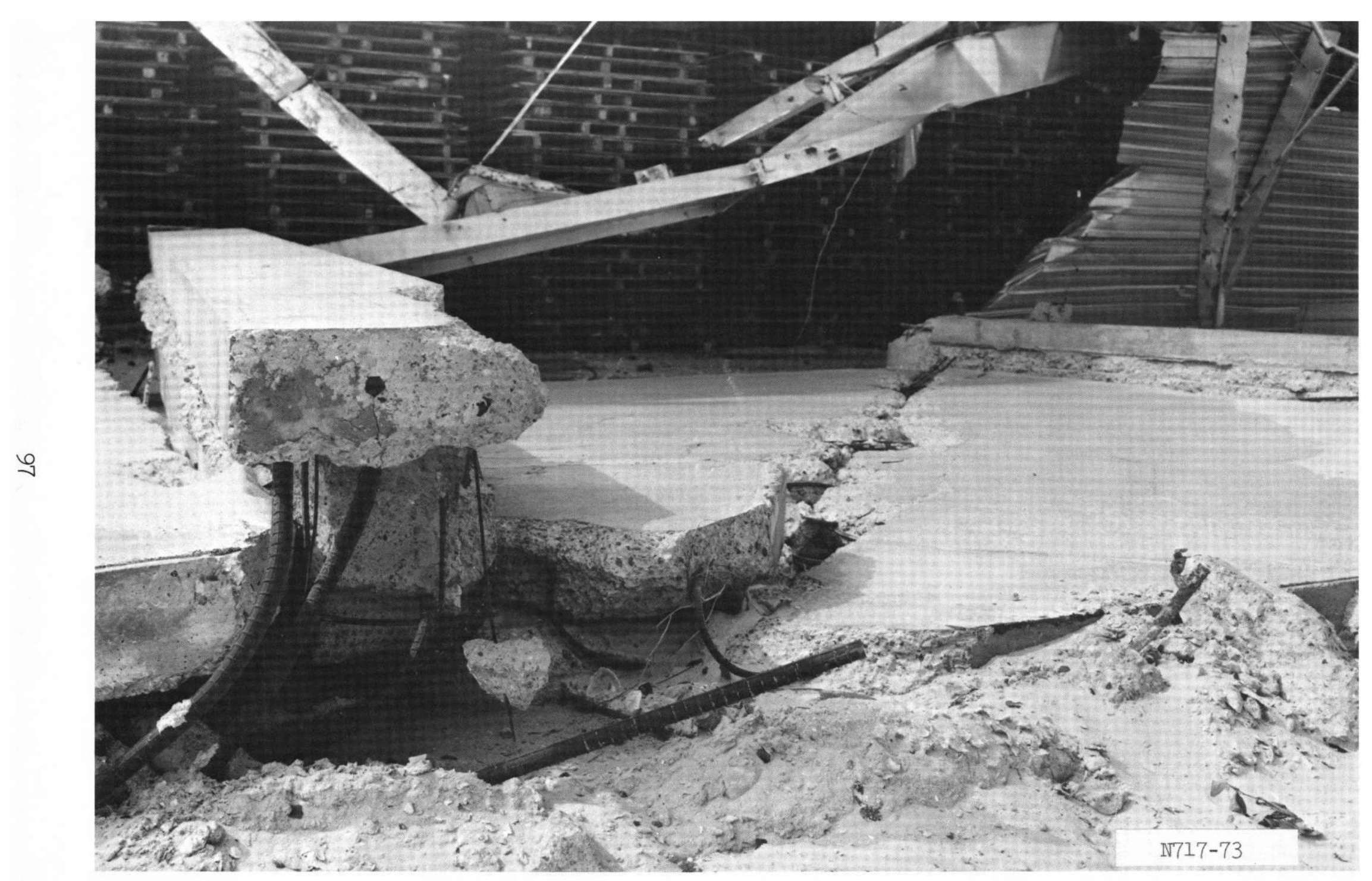

Figure 3.8 End-wall column and panel, State Dock. 


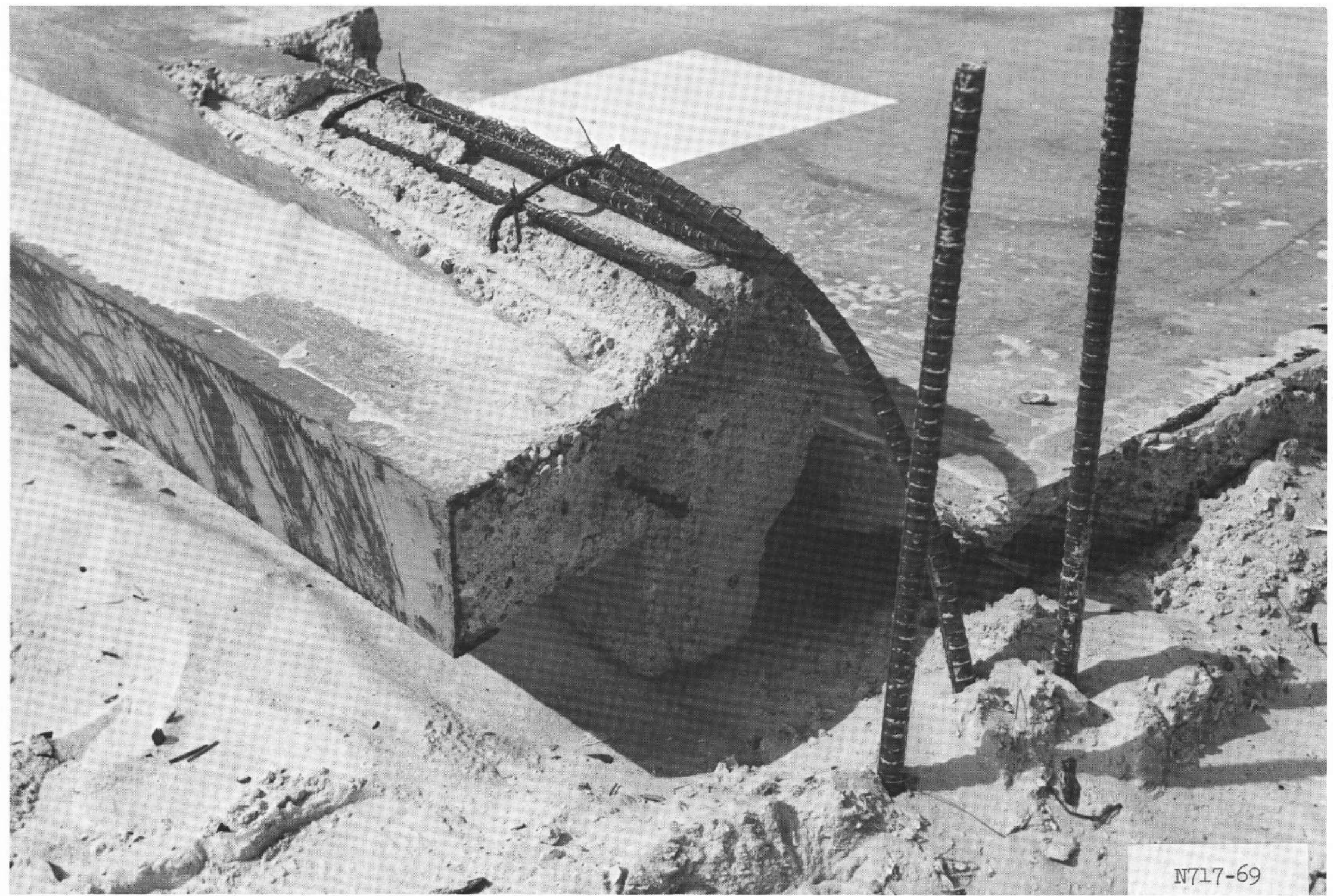

Figure 3.9 Dowels at base of end-wall column, State Dock. 


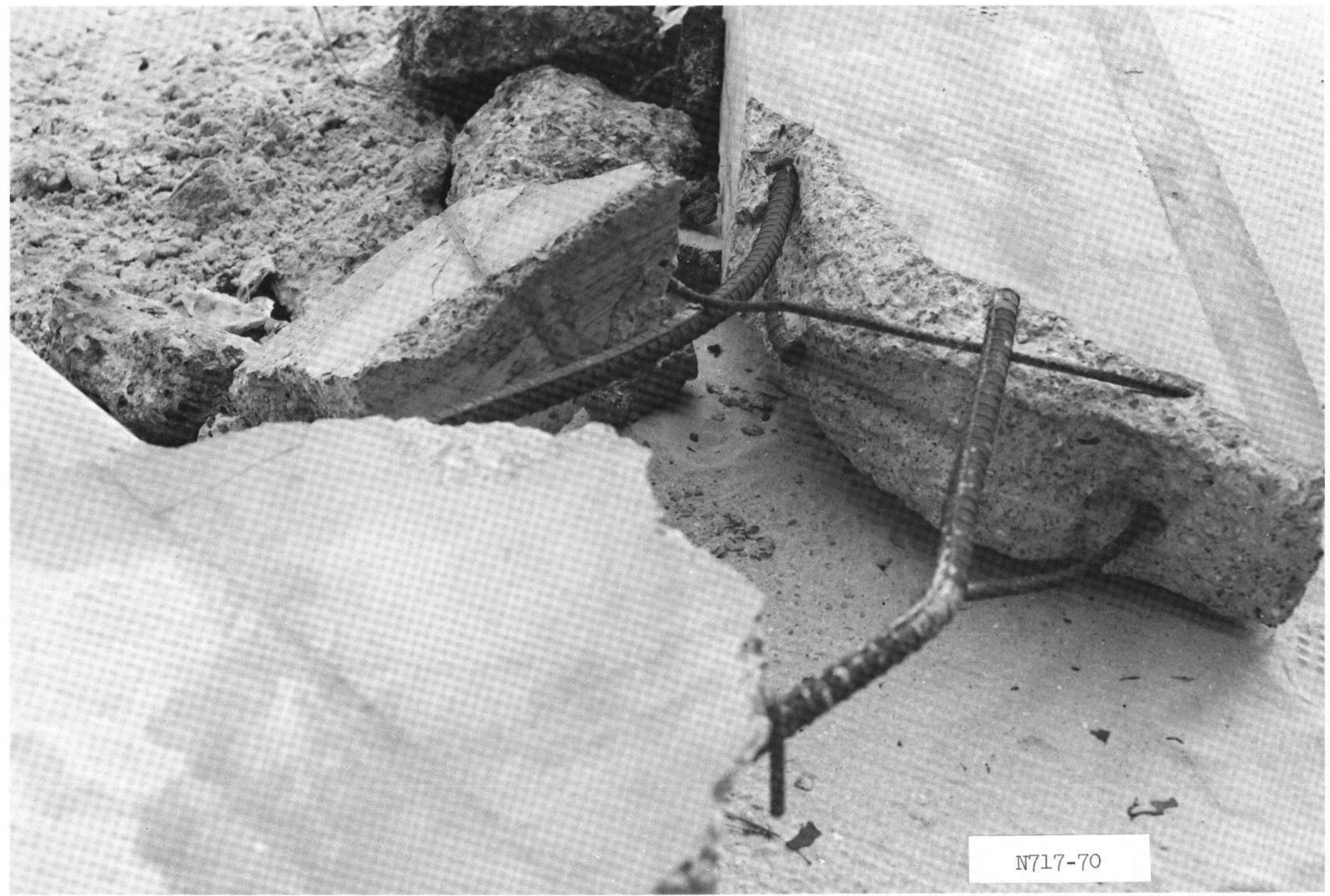

Figure 3.10 Ruptured bar on spandrel beam, State Dock. 


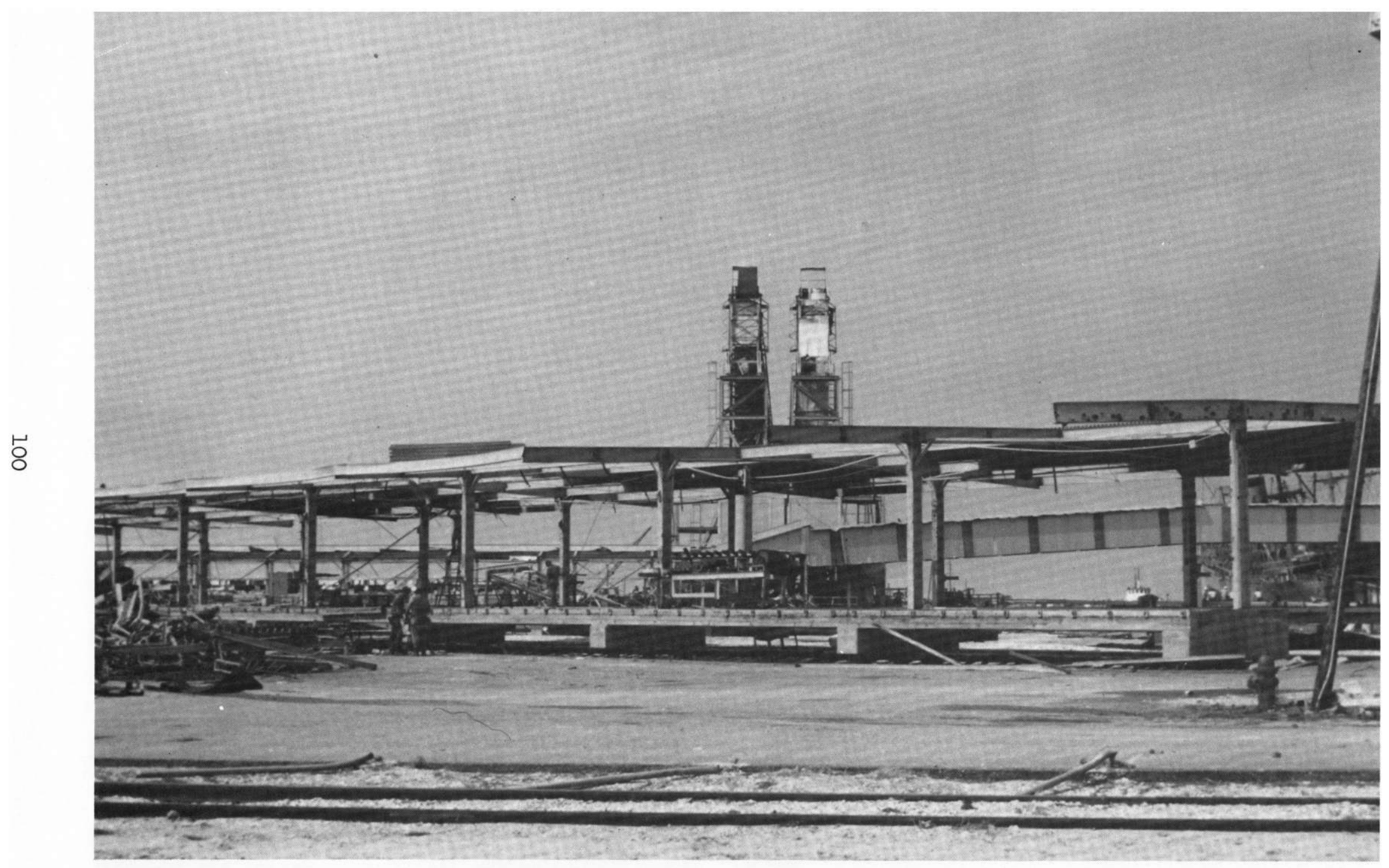

Figure 3.11 Buildings on east side of Port of Gulfport, Gulfport, Mississippi. 


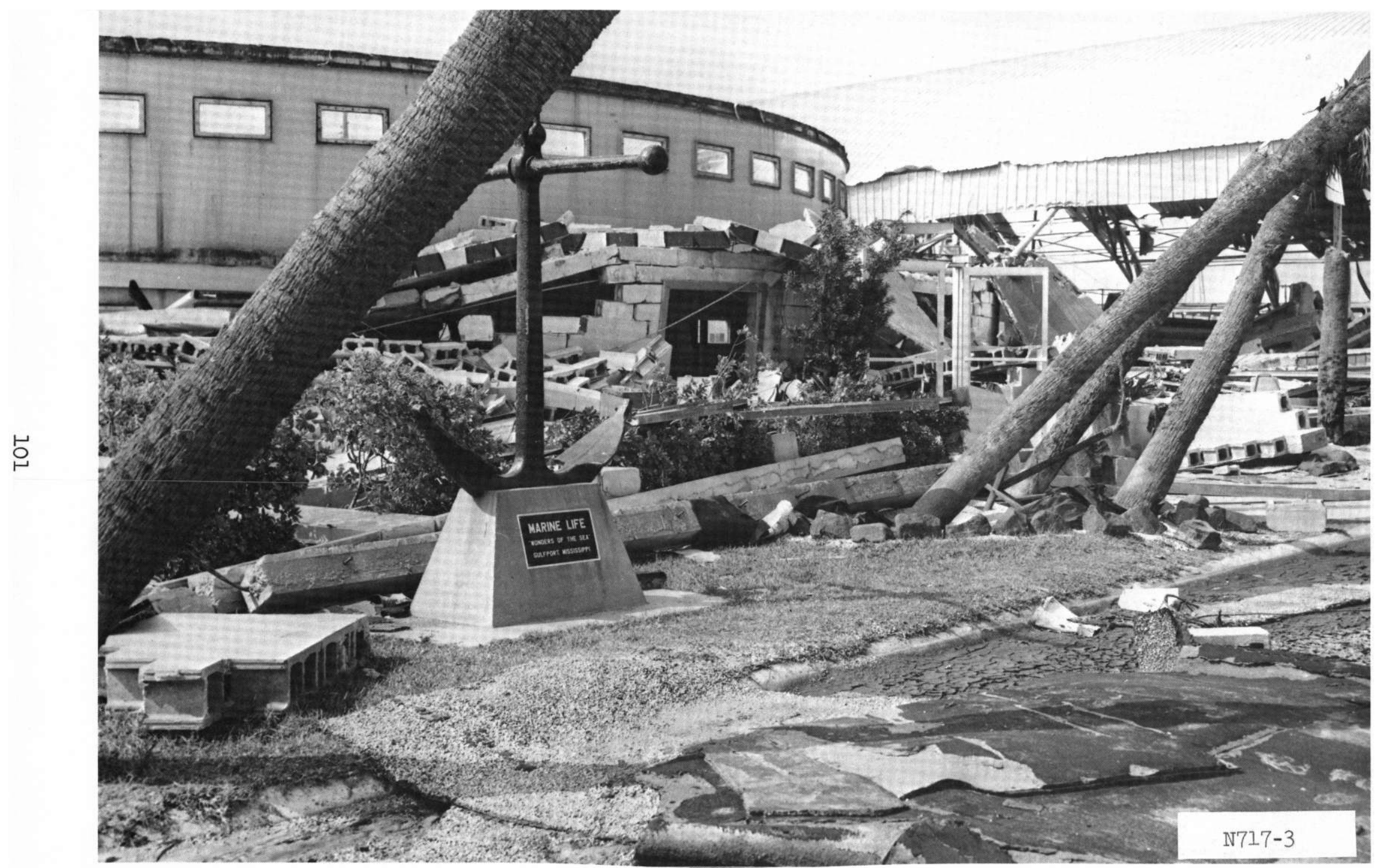

Figure 3.12 Marine Life Aquarium. 


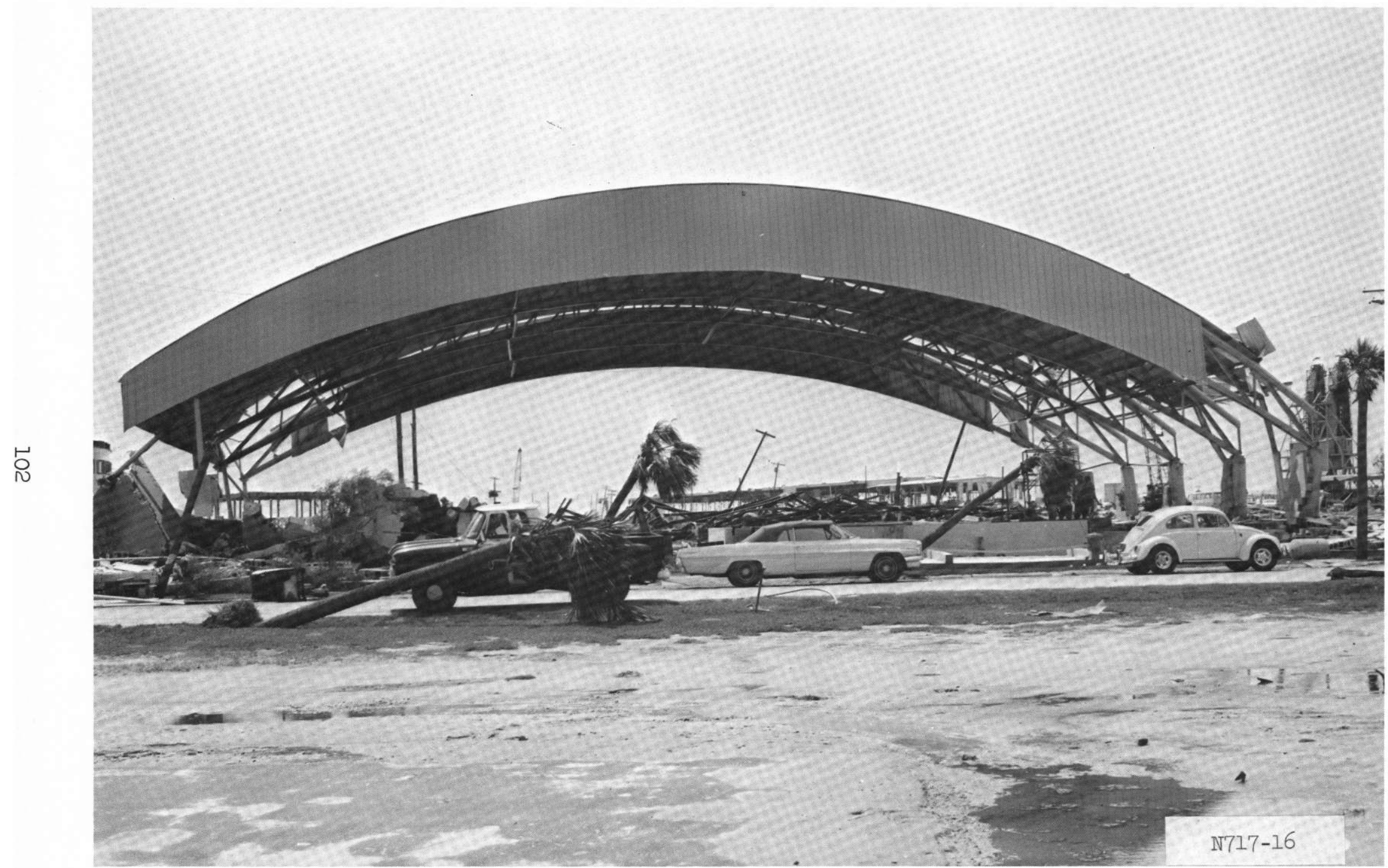

Figure 3.13 Marine Life steel arch. 


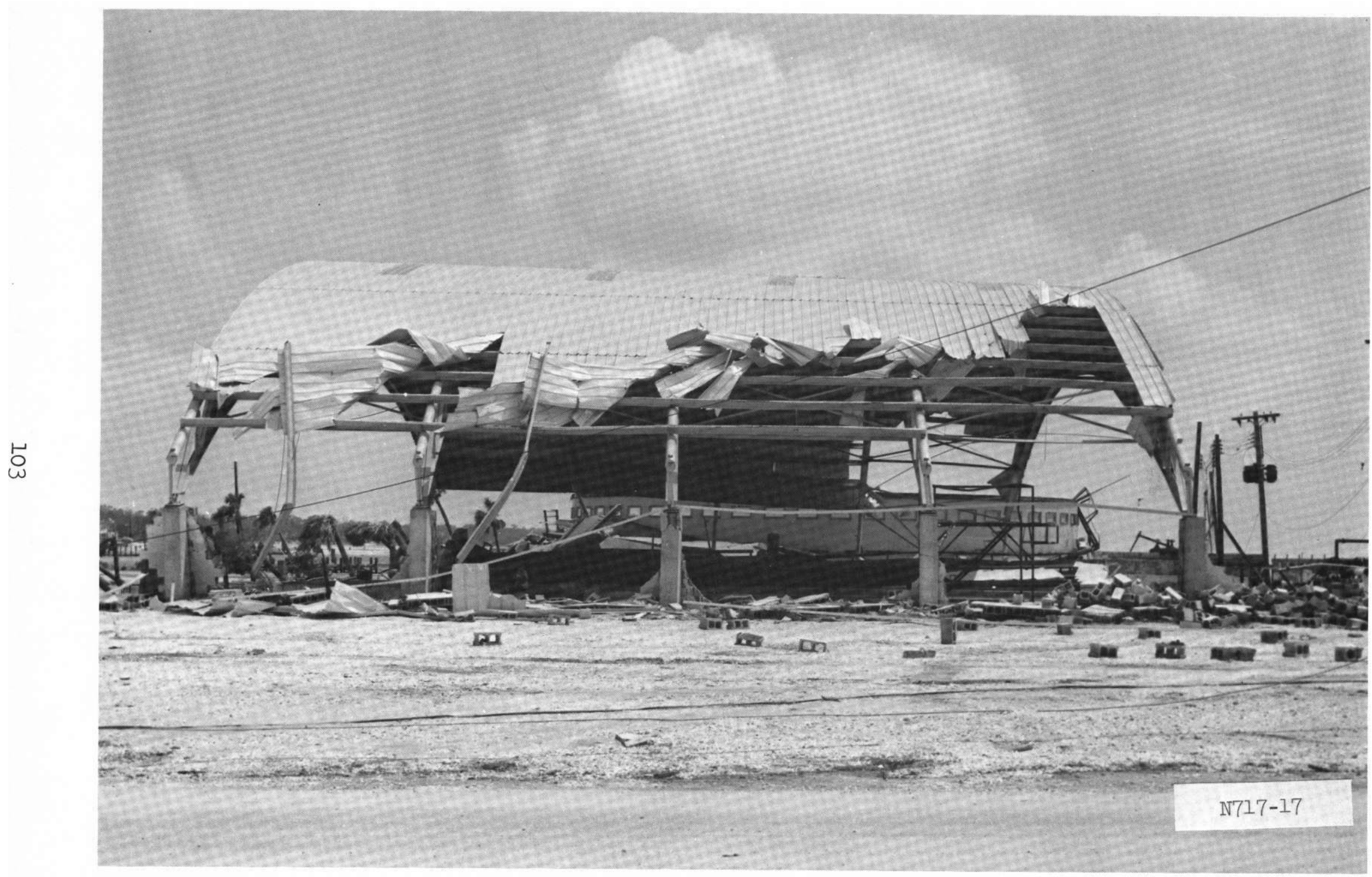

Figure 3.14 Marine Life arch. 


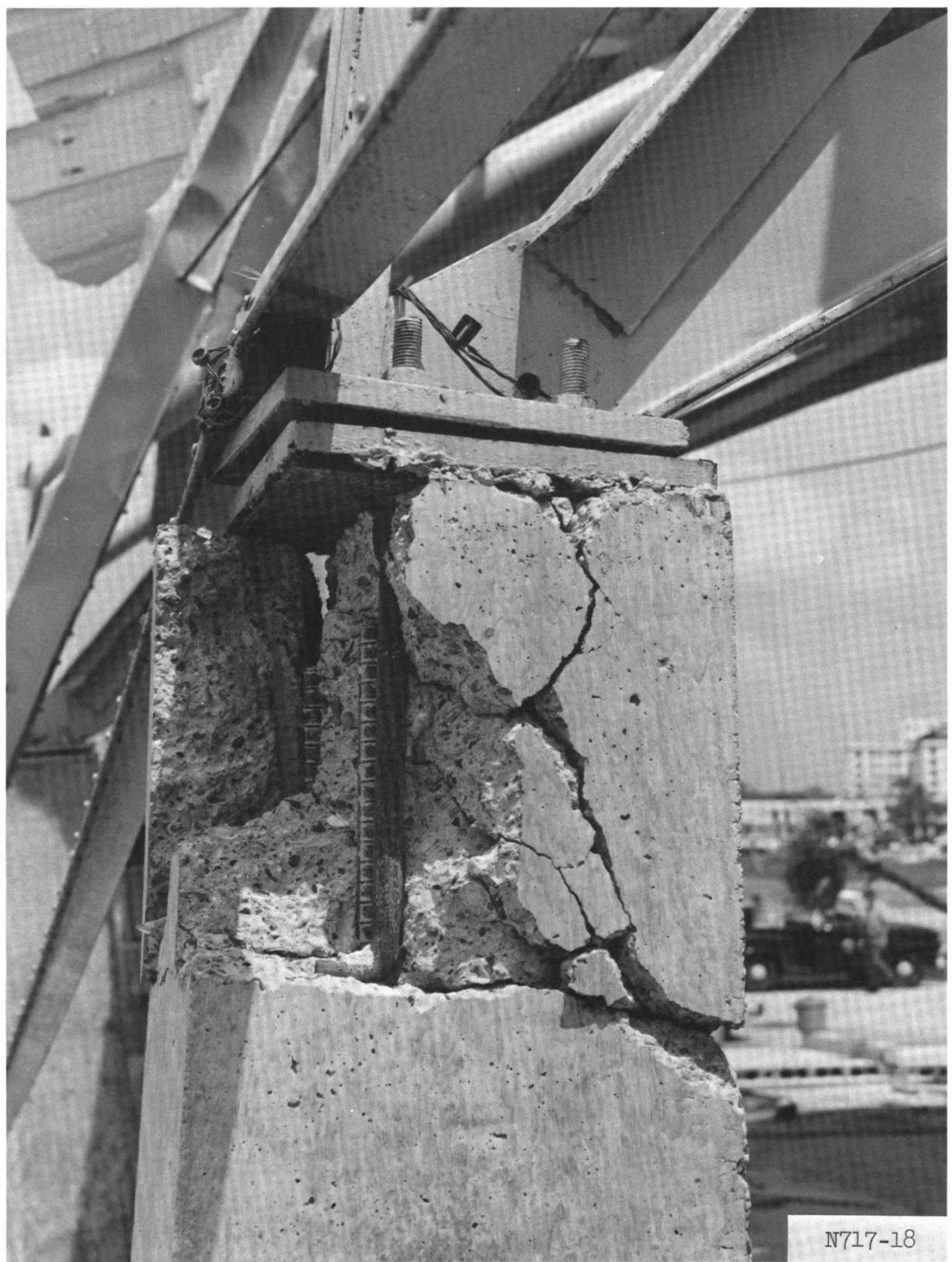

Figure 3.15 Center pier supporting west end of arch, Marine Life. 


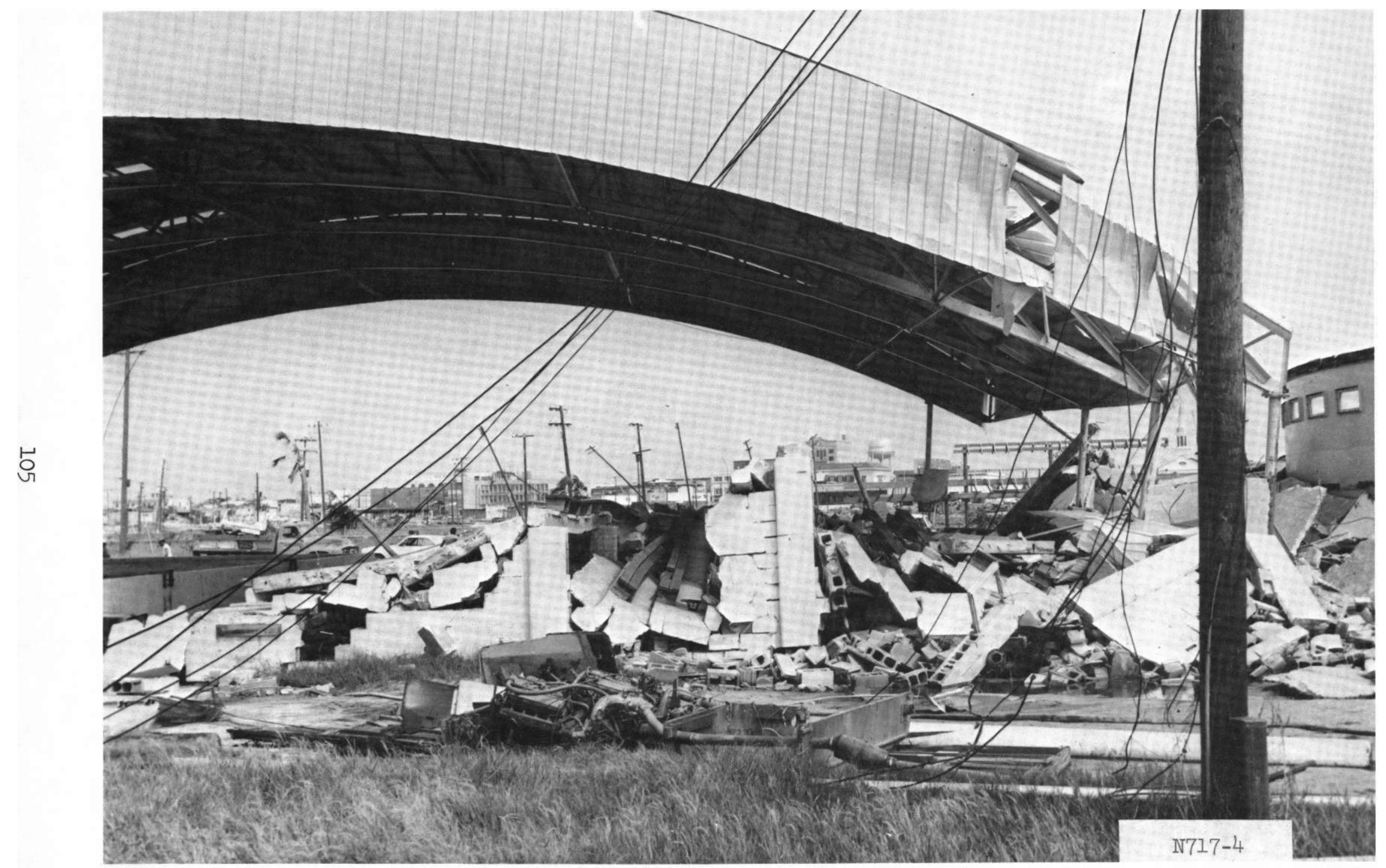

Figure 3.16 Southeast corner of Marine Life arch. 


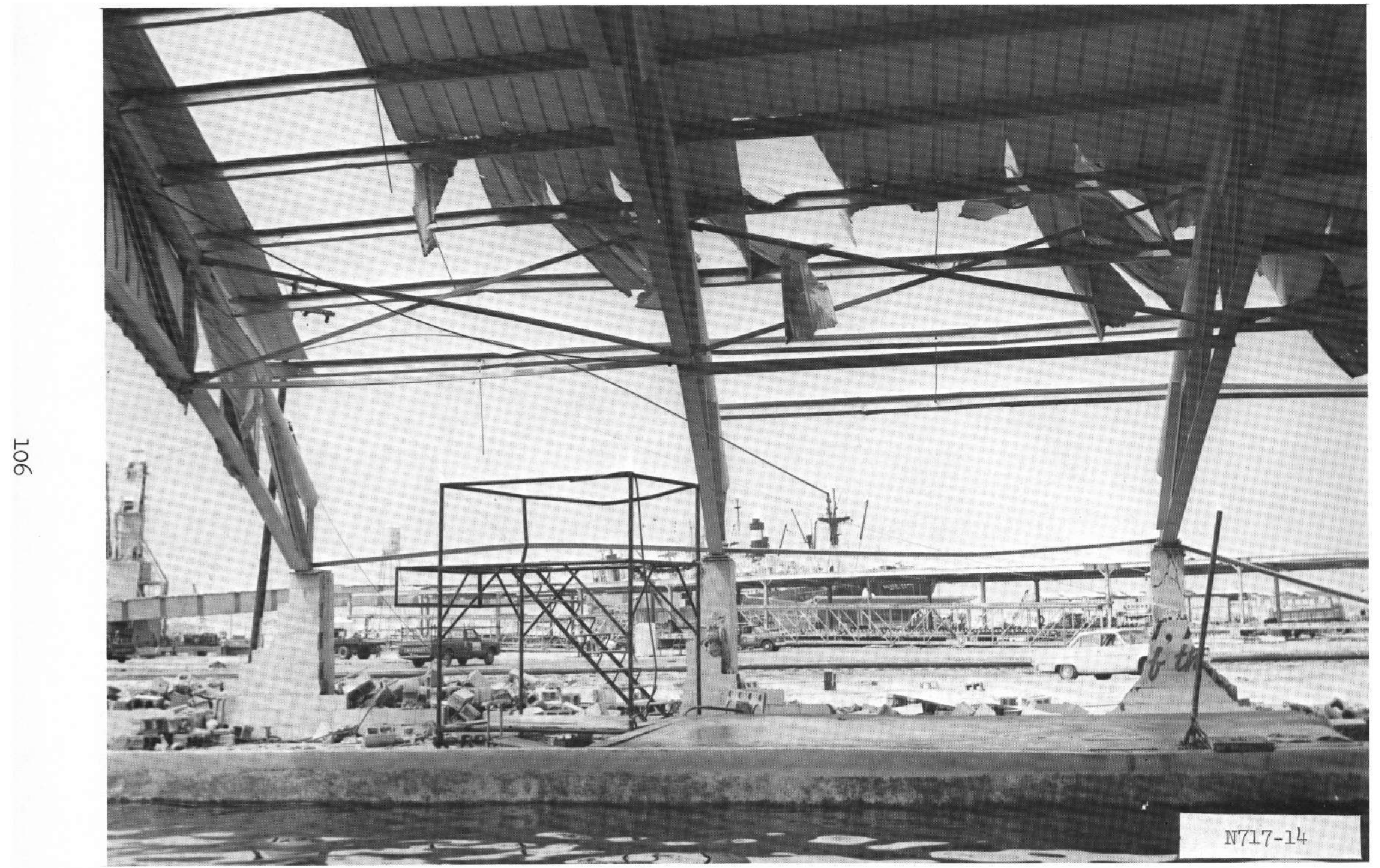

Figure 3.17 West end of Marine Life arch. 


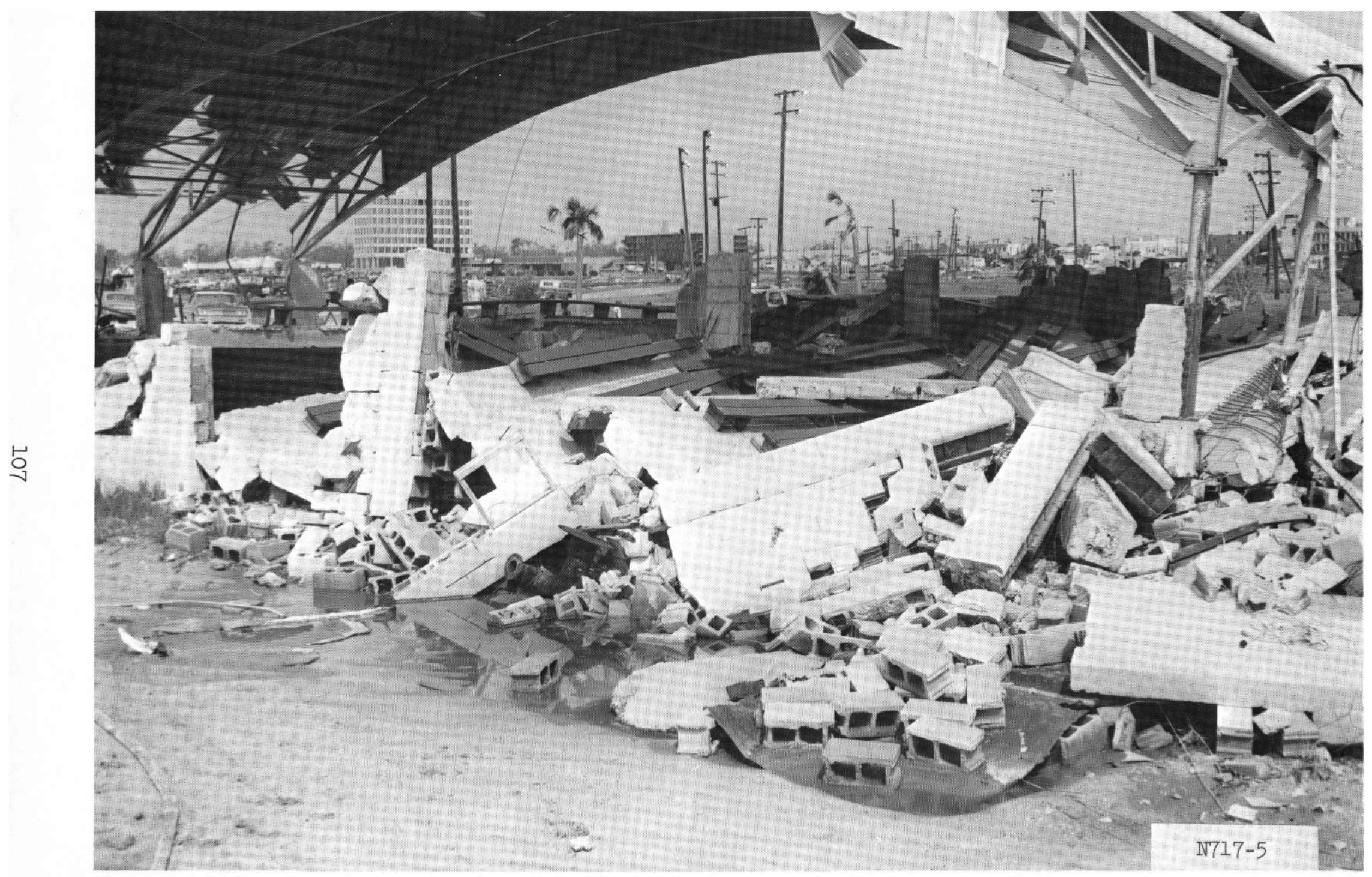

Figure 3.18 Seating area under Marine Life arch. 


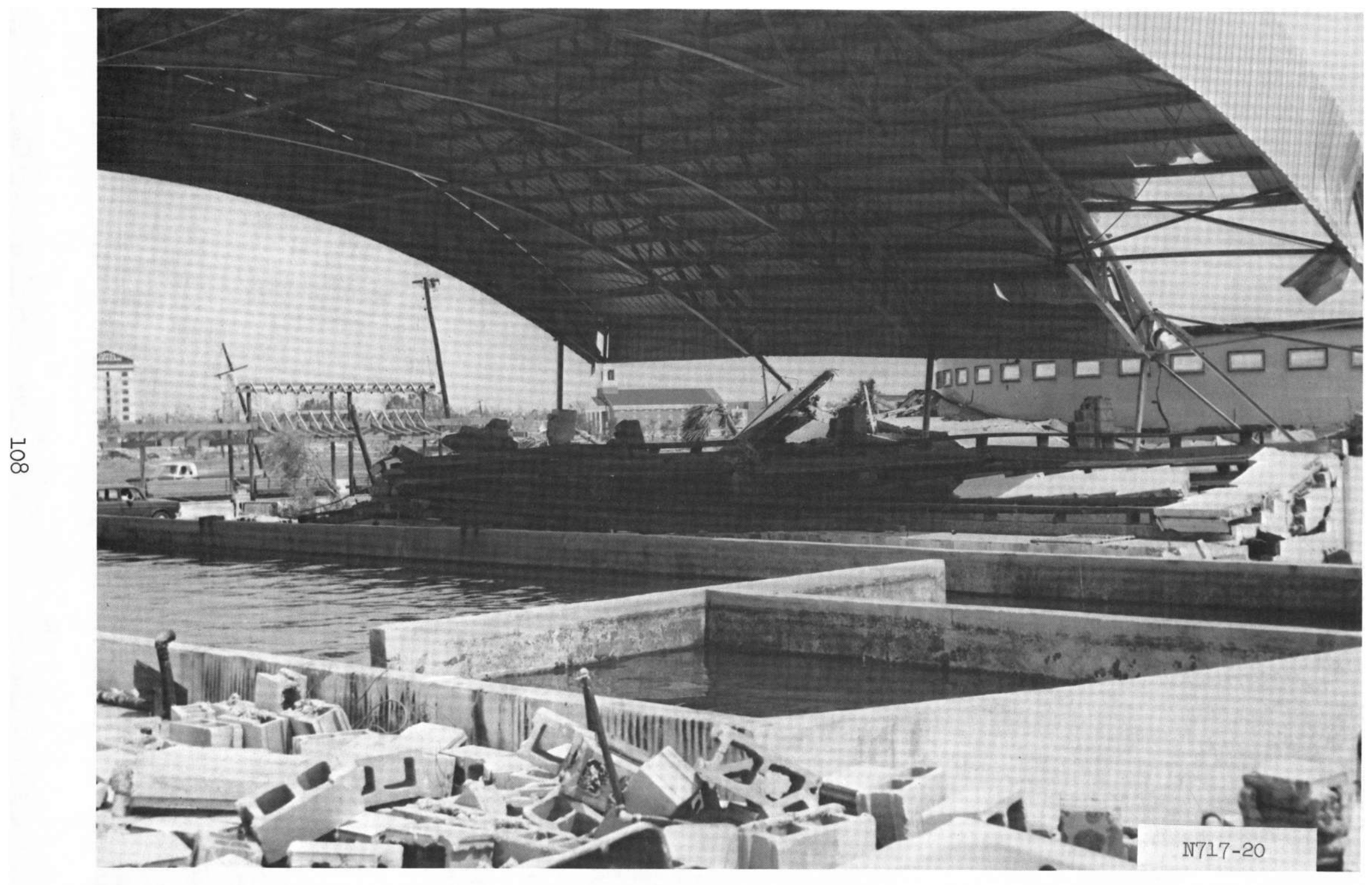

Figure 3.19 Seating area and arch at Marine Life. 


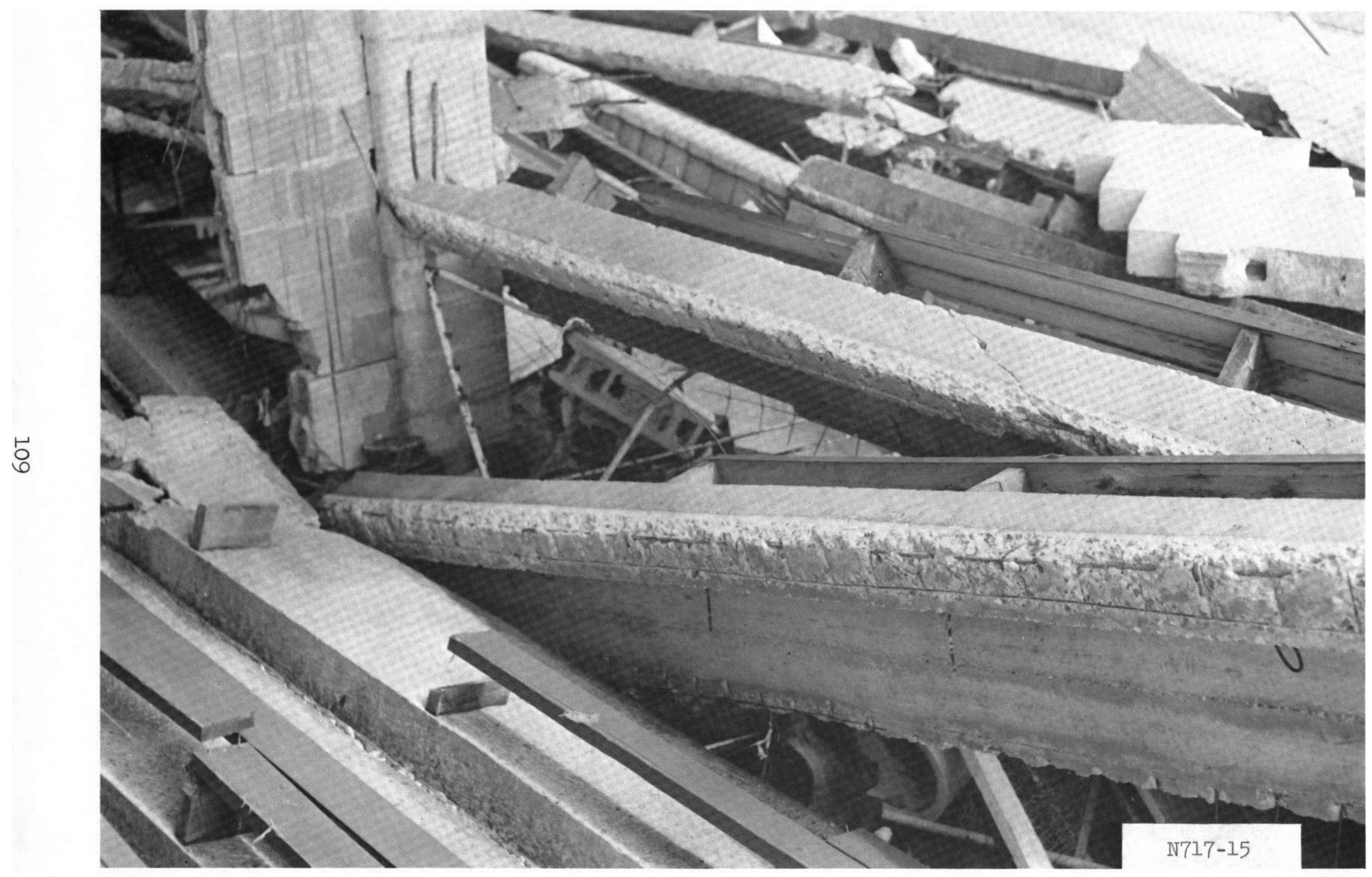

Figure 3.20 Close-up of seating area, Marine Life. 


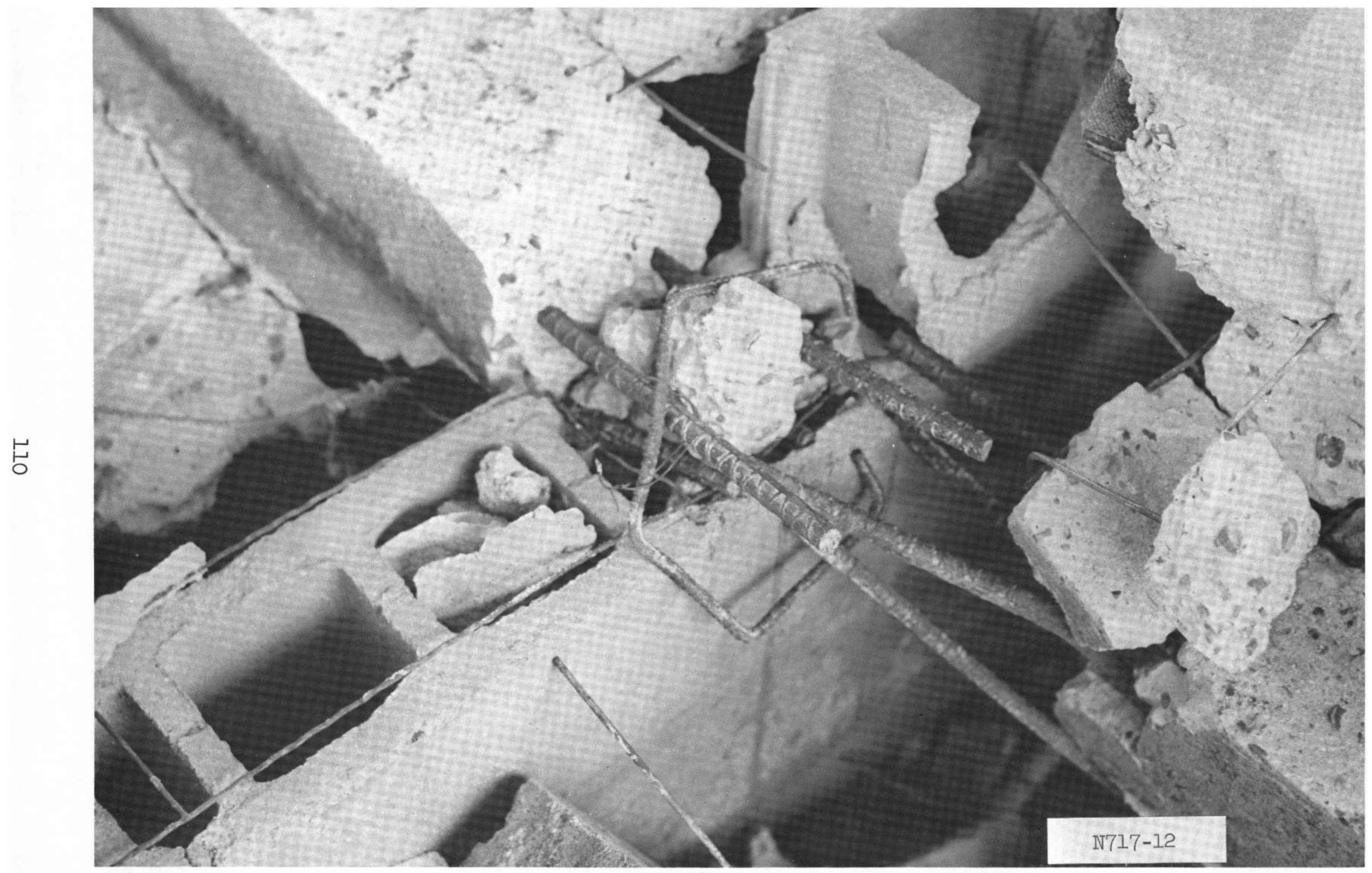

Figure 3.21 Overhead view of beam failure over block wall, Marine Life. 


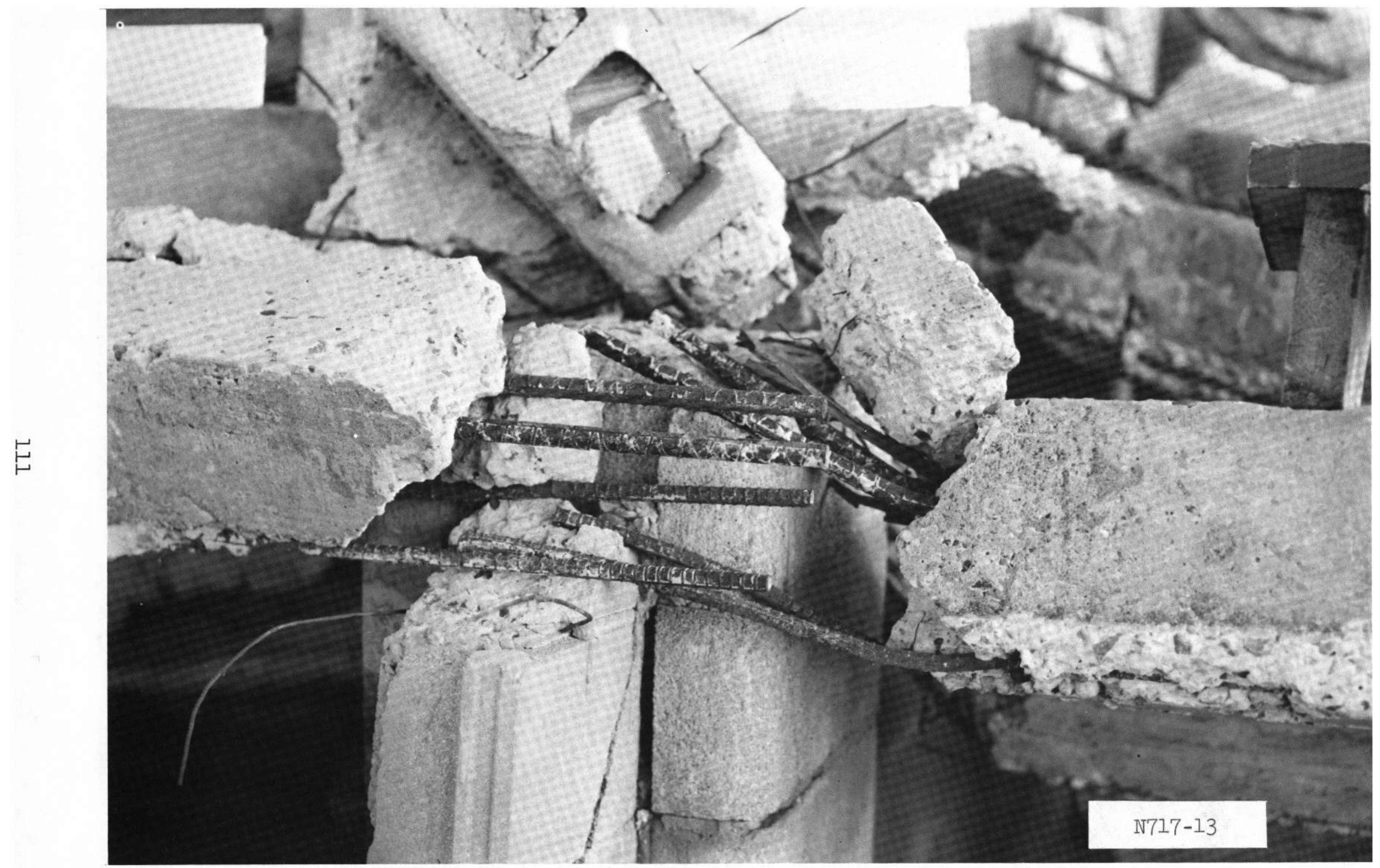

Figure 3.22 Side view of beam failure over block wall, Marine Life. 


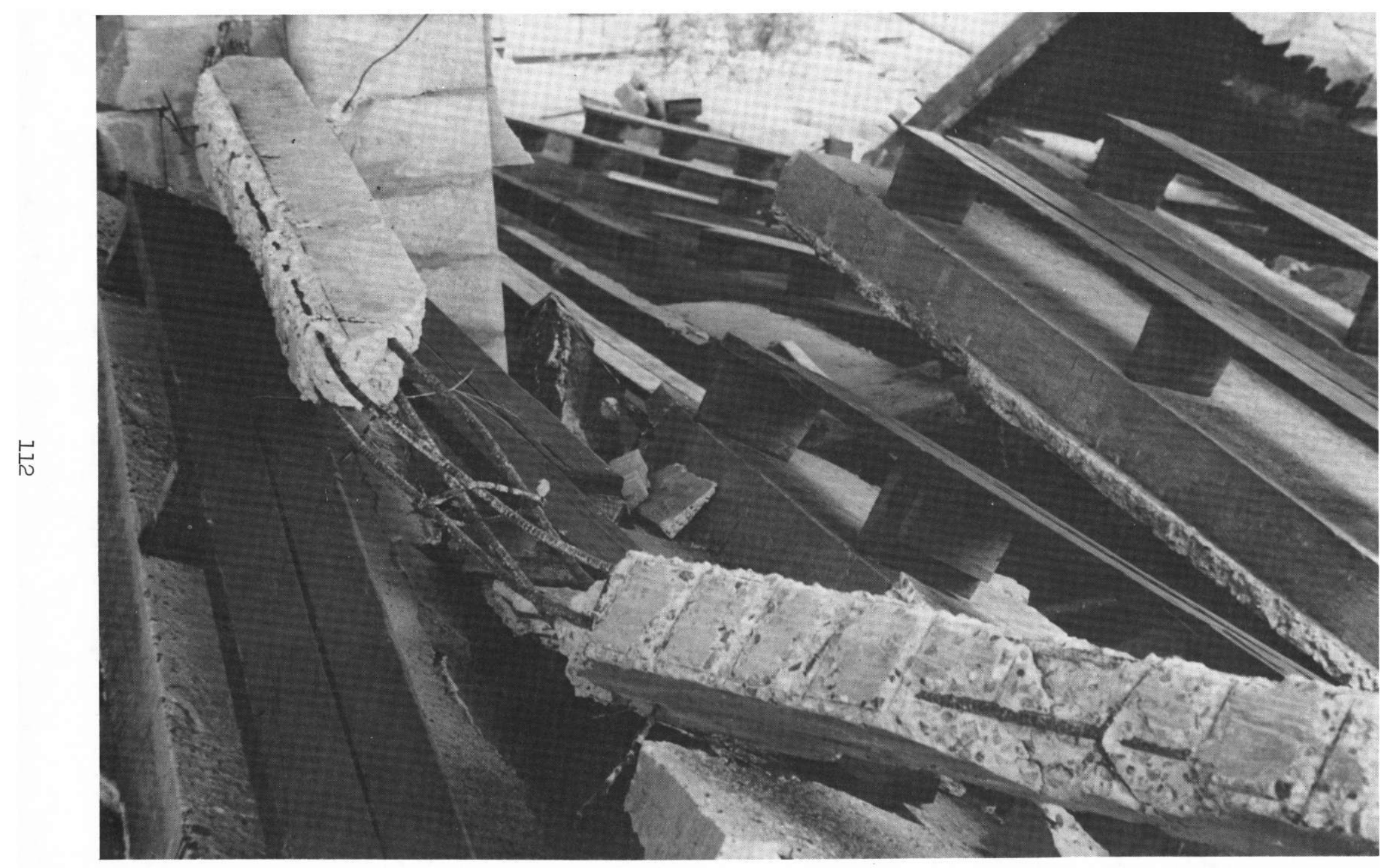

Figure 3.23 Beam failed in torsion, seating area of Marine Life. 


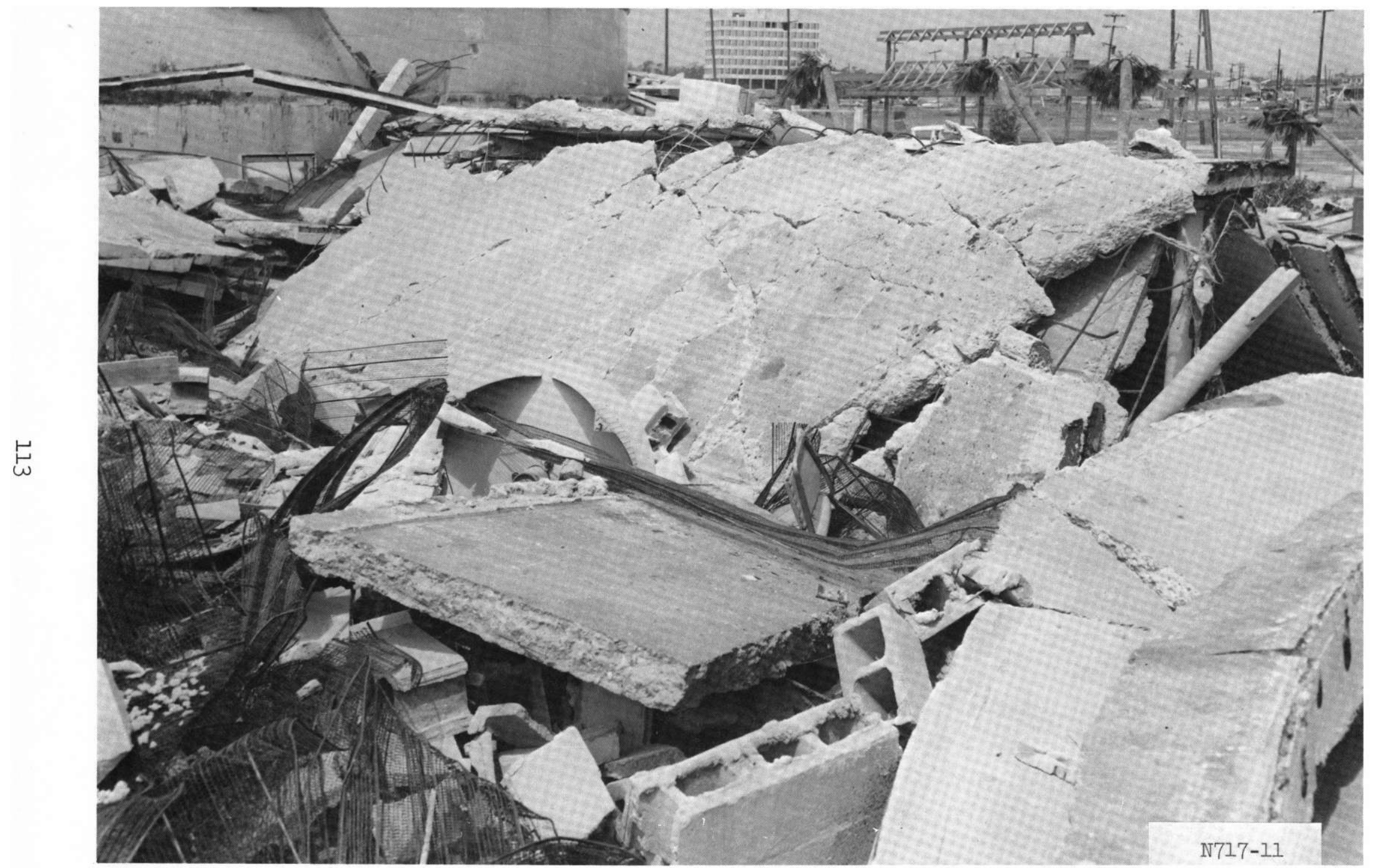

Figure 3.24 Structure around large tank, Marine Life. 


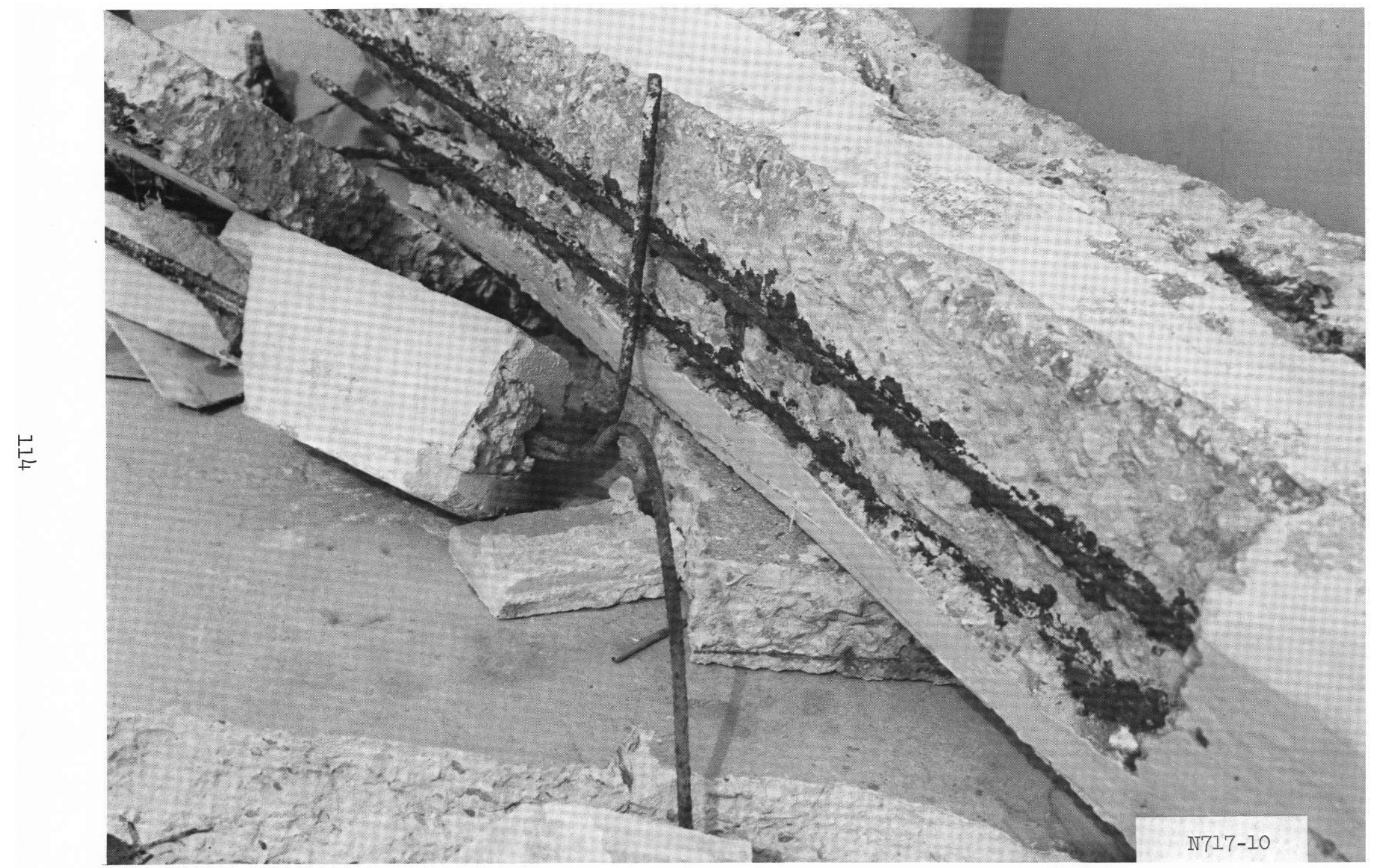

Figure 3.25 Reinforcement corrosion in a beam, Marine Life. 


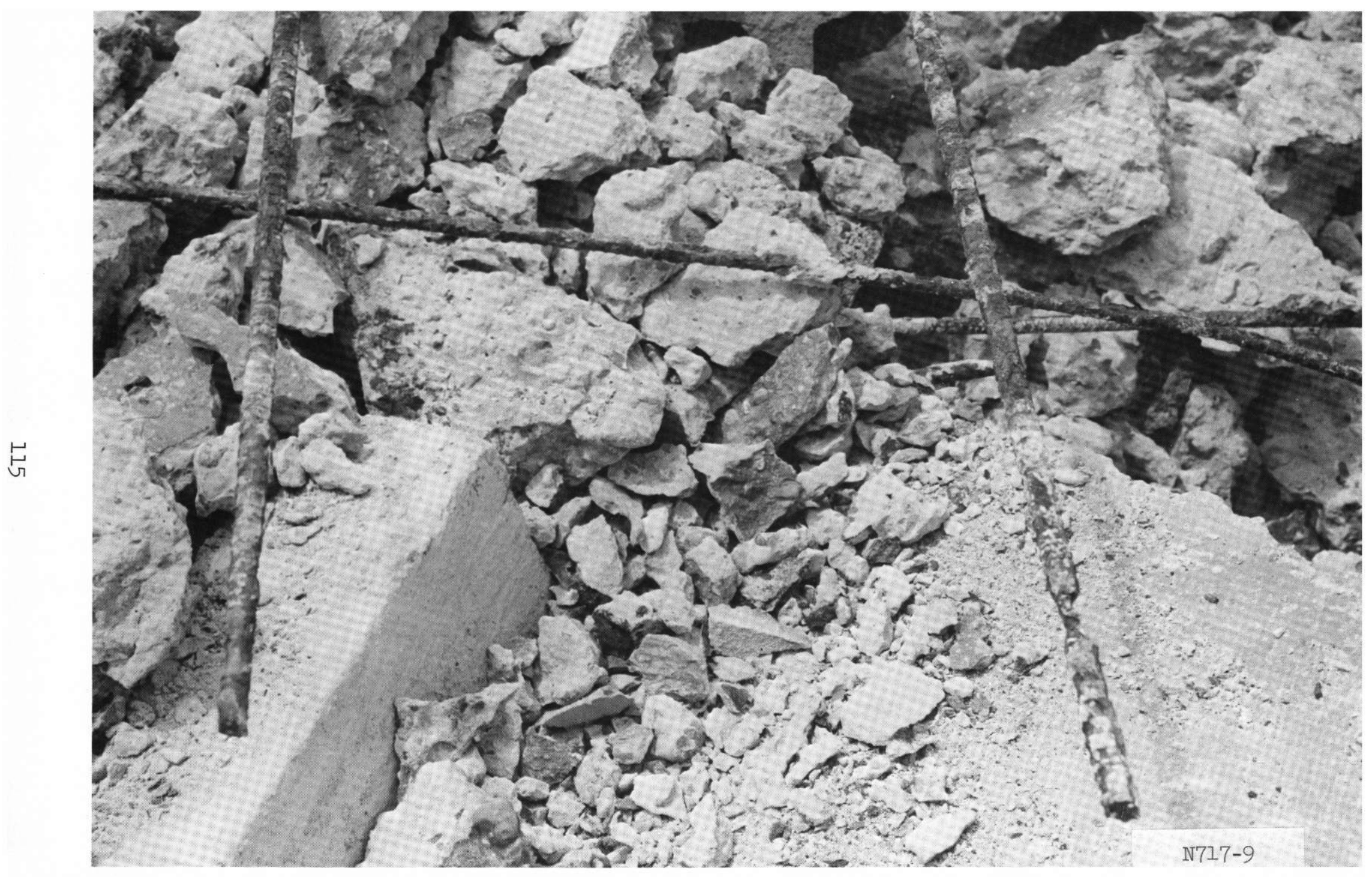

Figure 3.26 Reinforcement corrosion in a slab, Marine Life. 


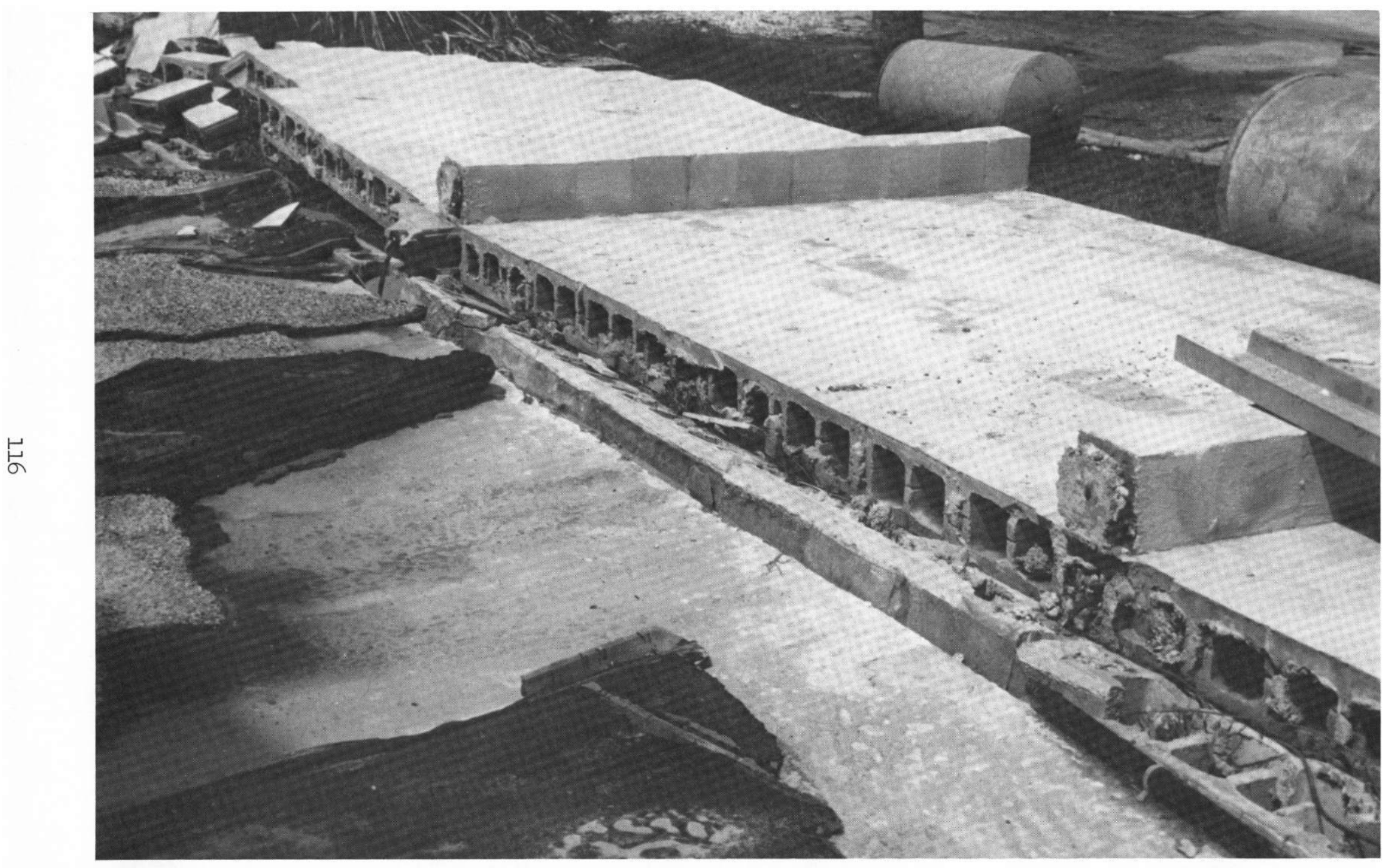

Figure 3.27 Block wall north of Marine Life arch. 


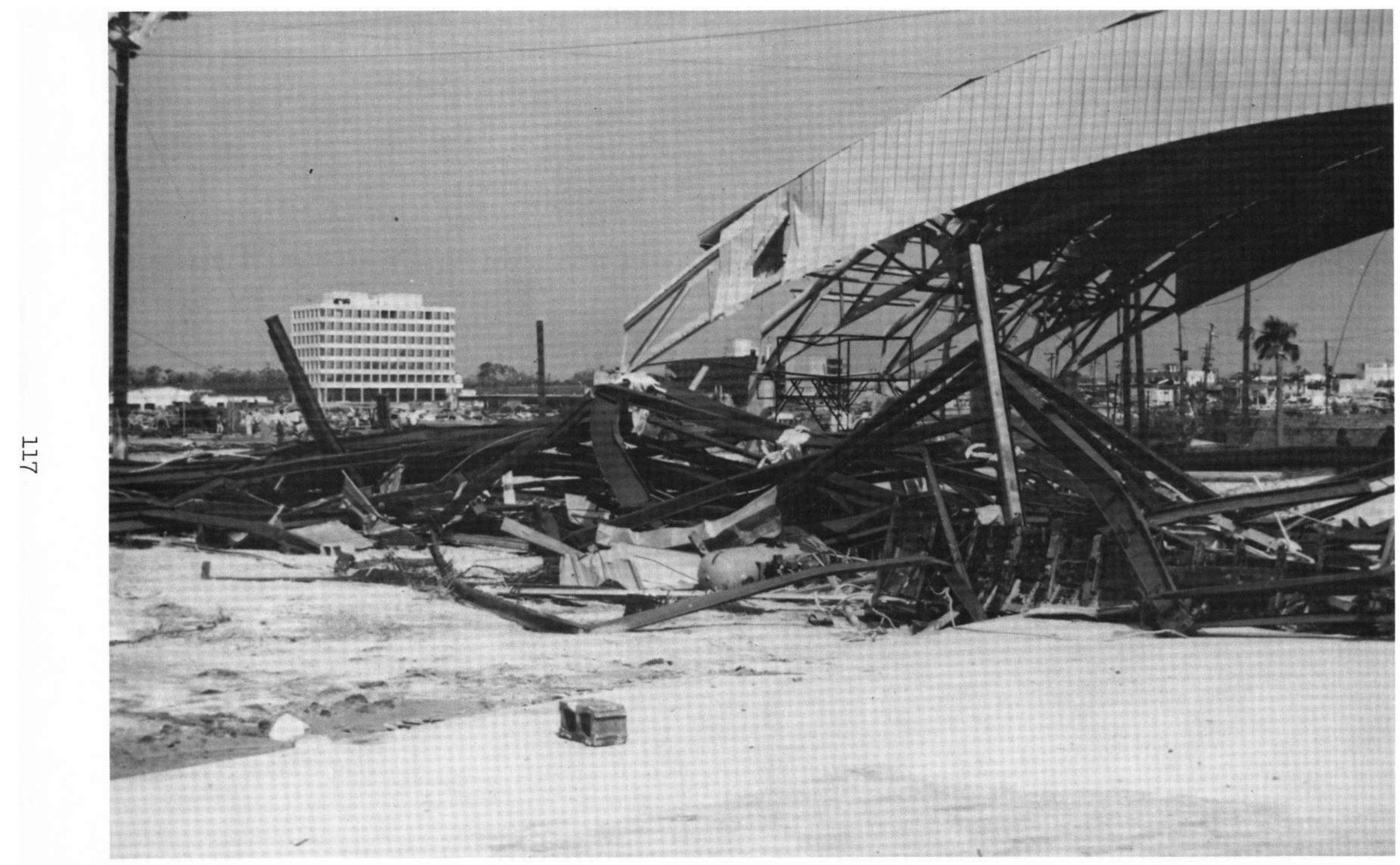

Figure 3.28 Steel frame of Marine Shop south of Marine Life. 


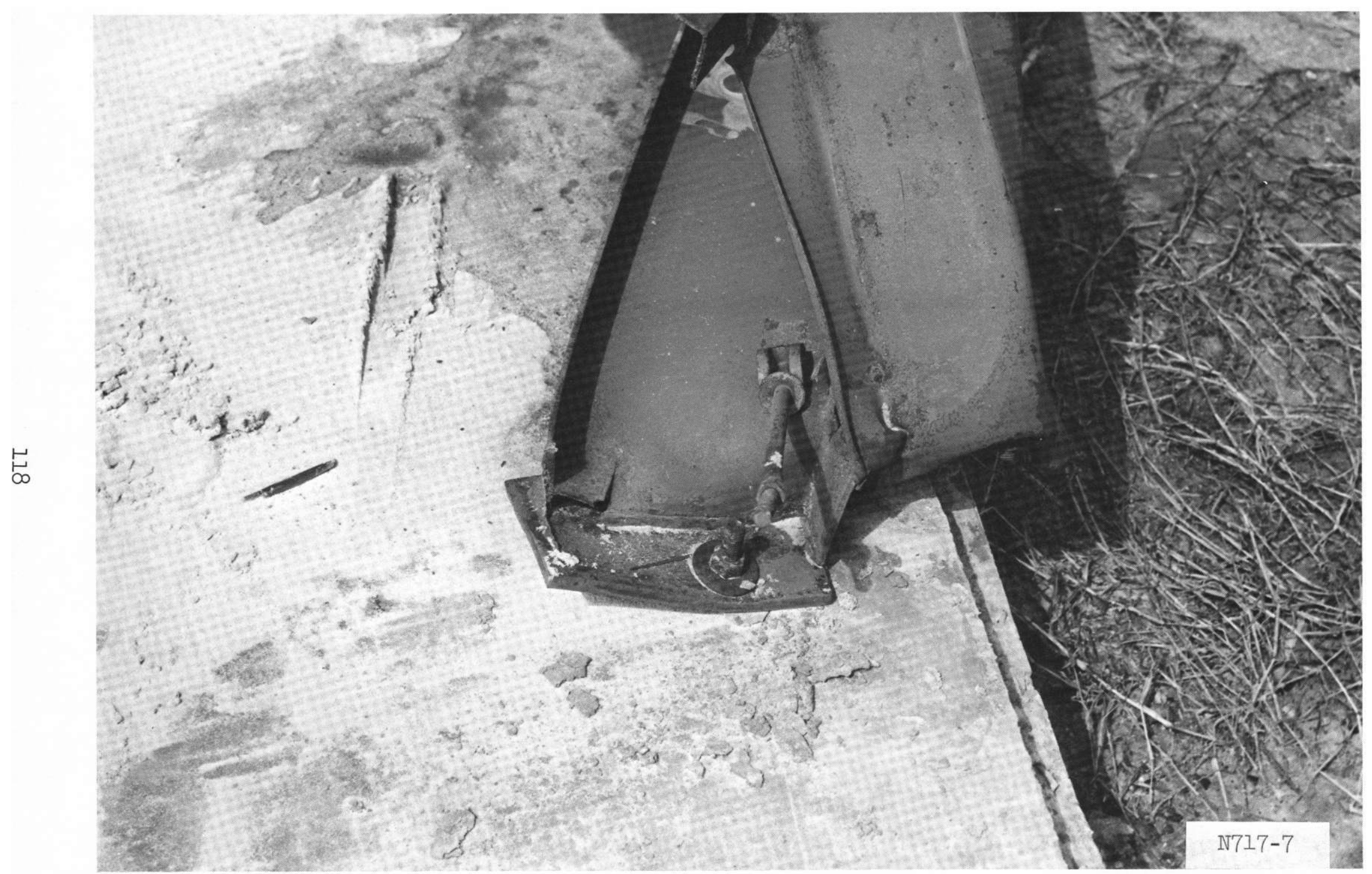

Figure 3.29 Base of column at Marine Shop. 


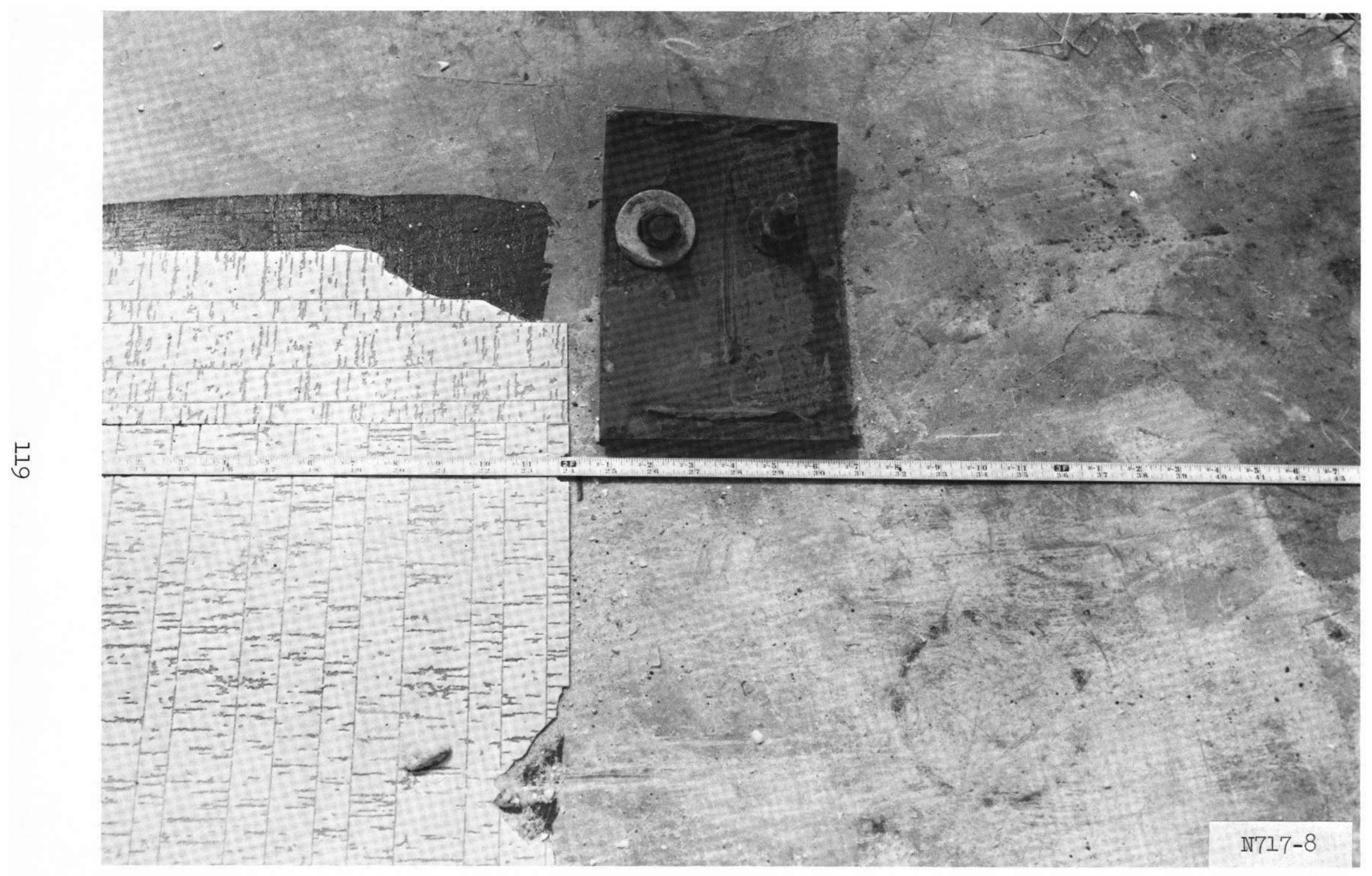

Figure 3.30 Base plate for steel column, Marine Shop. 


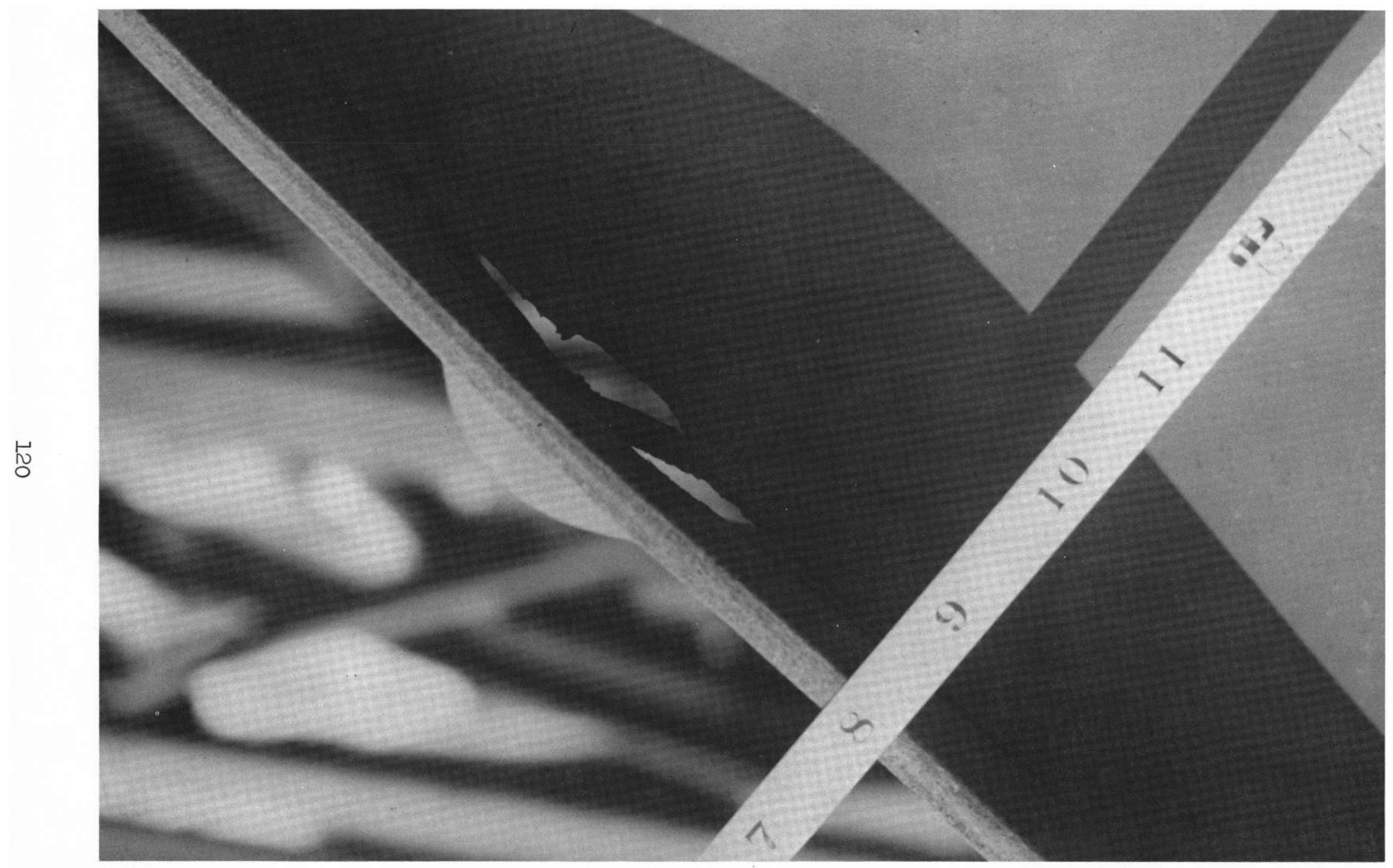

Figure 3.31 Weld failure of a plate girder, Marine Shop. 


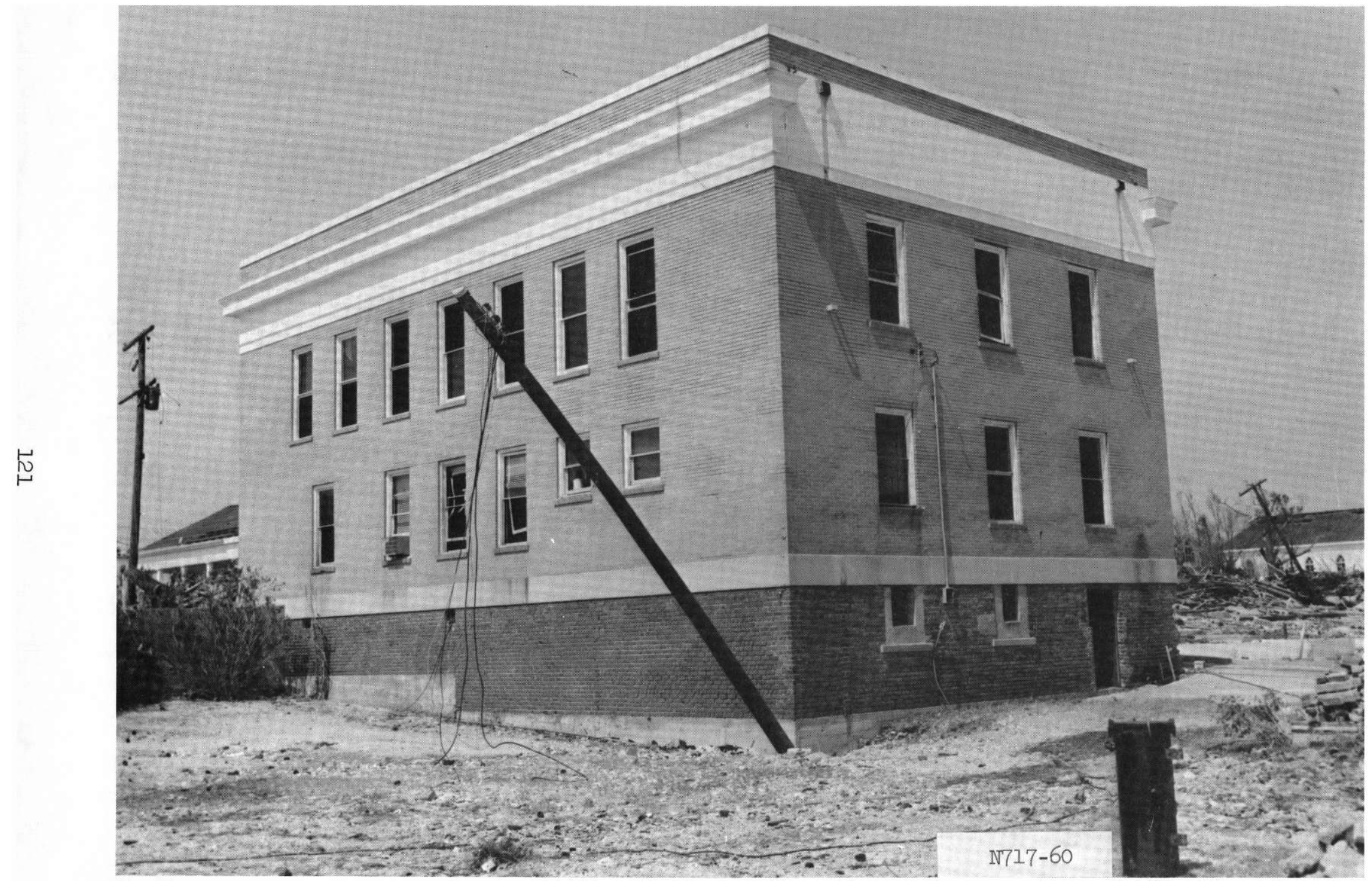

Figure 3.32 Pass Christian City Hall. 


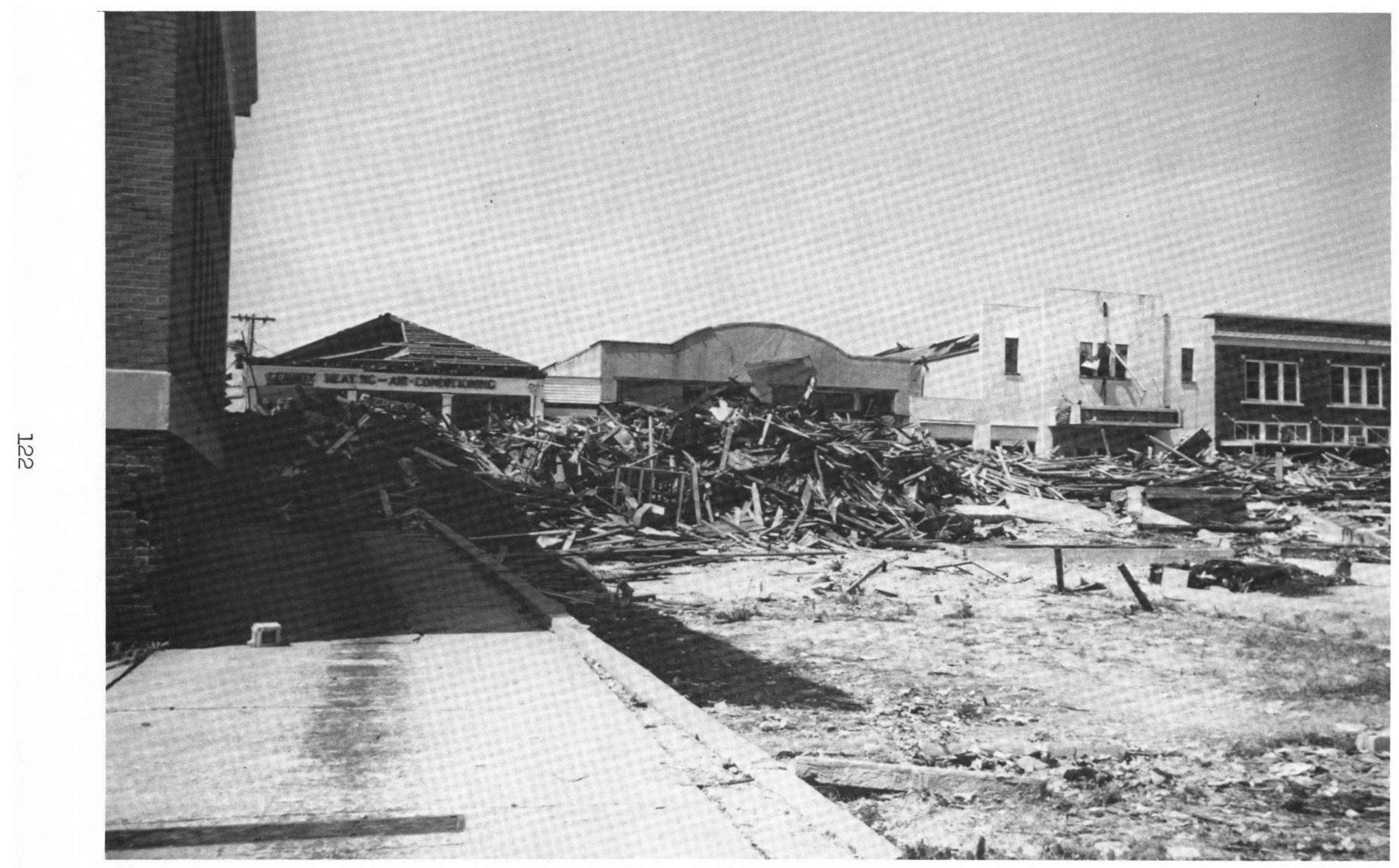

Figure 3.33 Businesses behind and east of Pass Christian City Hall. 


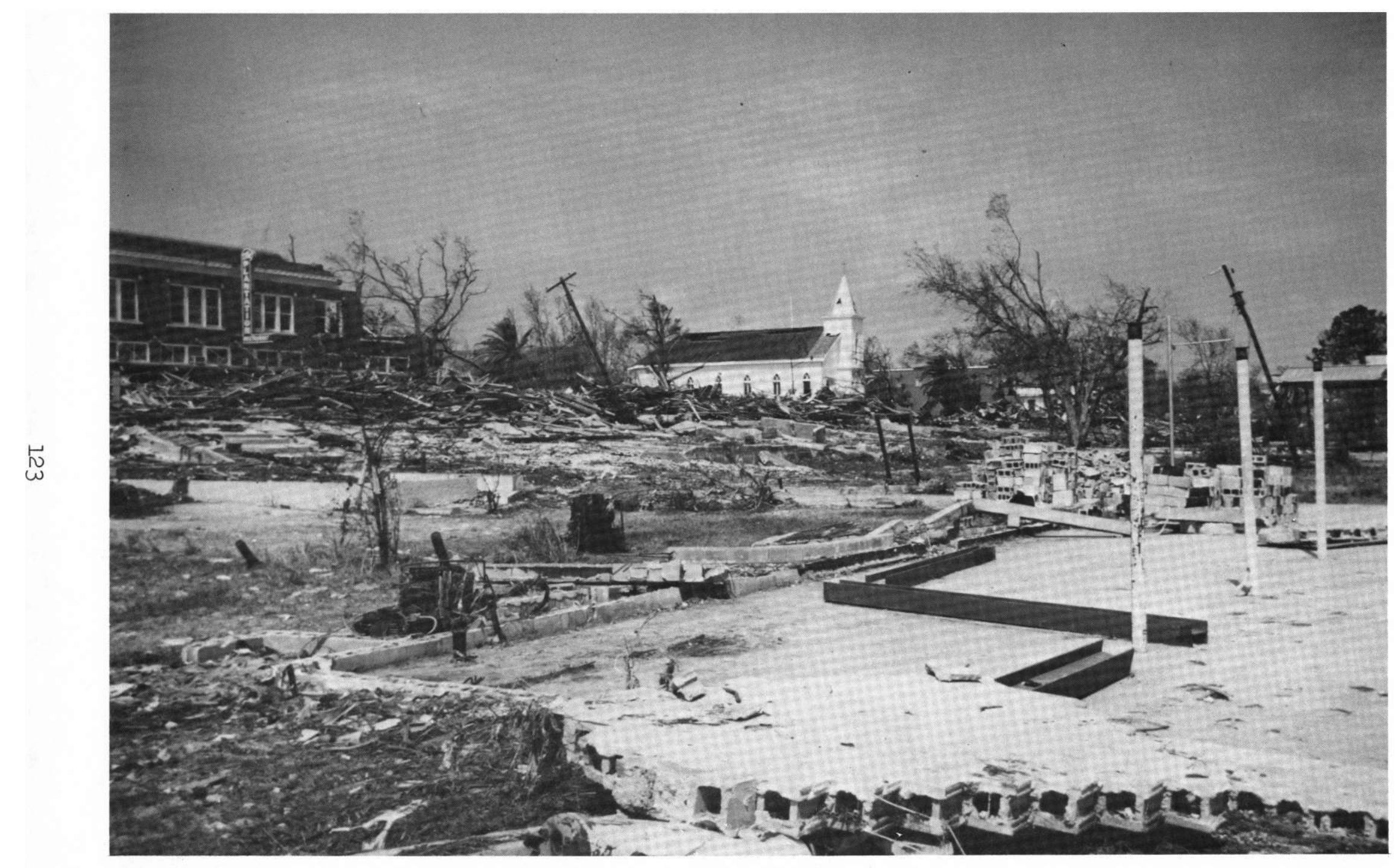

Figure 3.34 Area east of Pass Christian City Hall. 


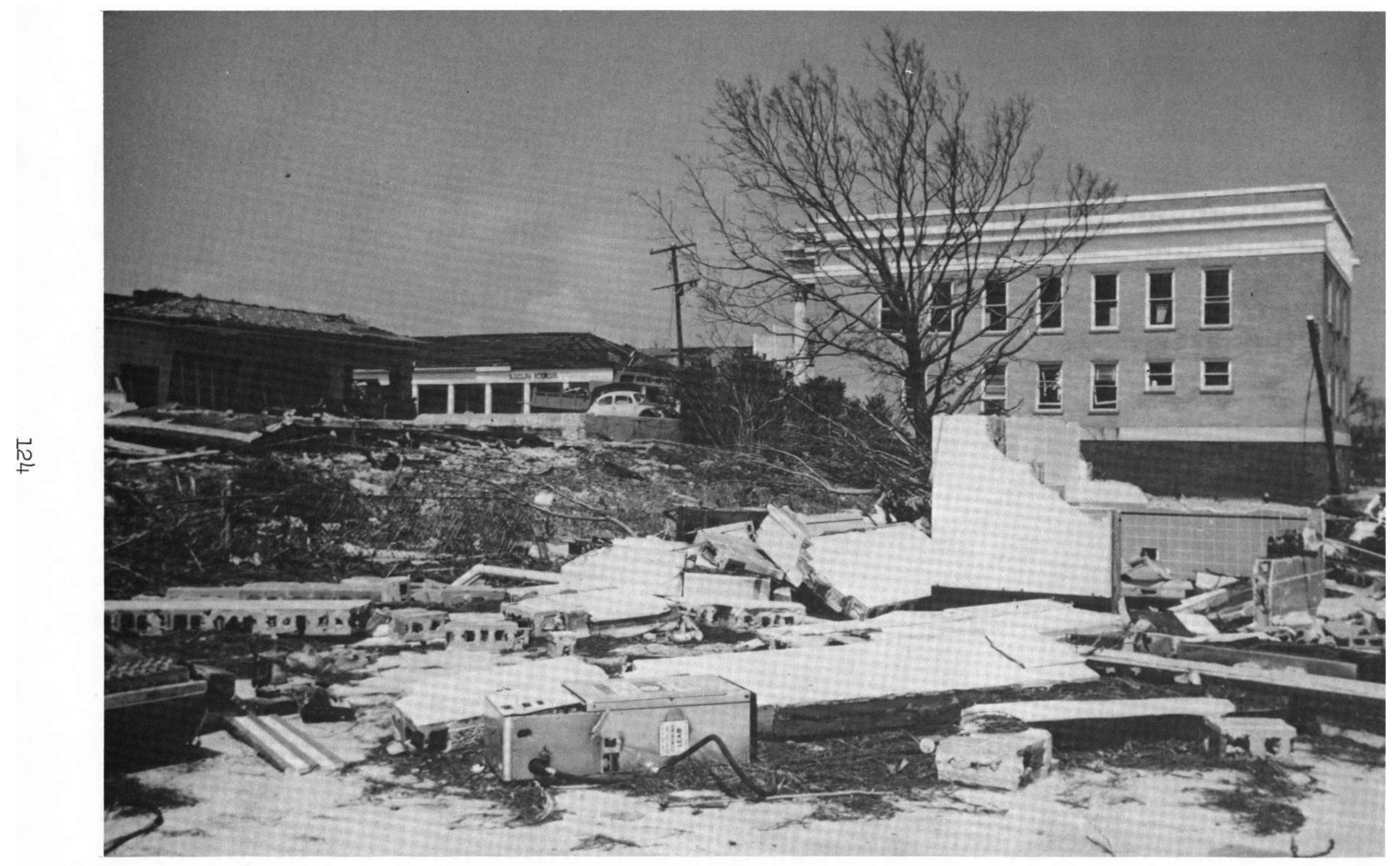

Figure 3.35 Area west of Pass Christian City Hall. 


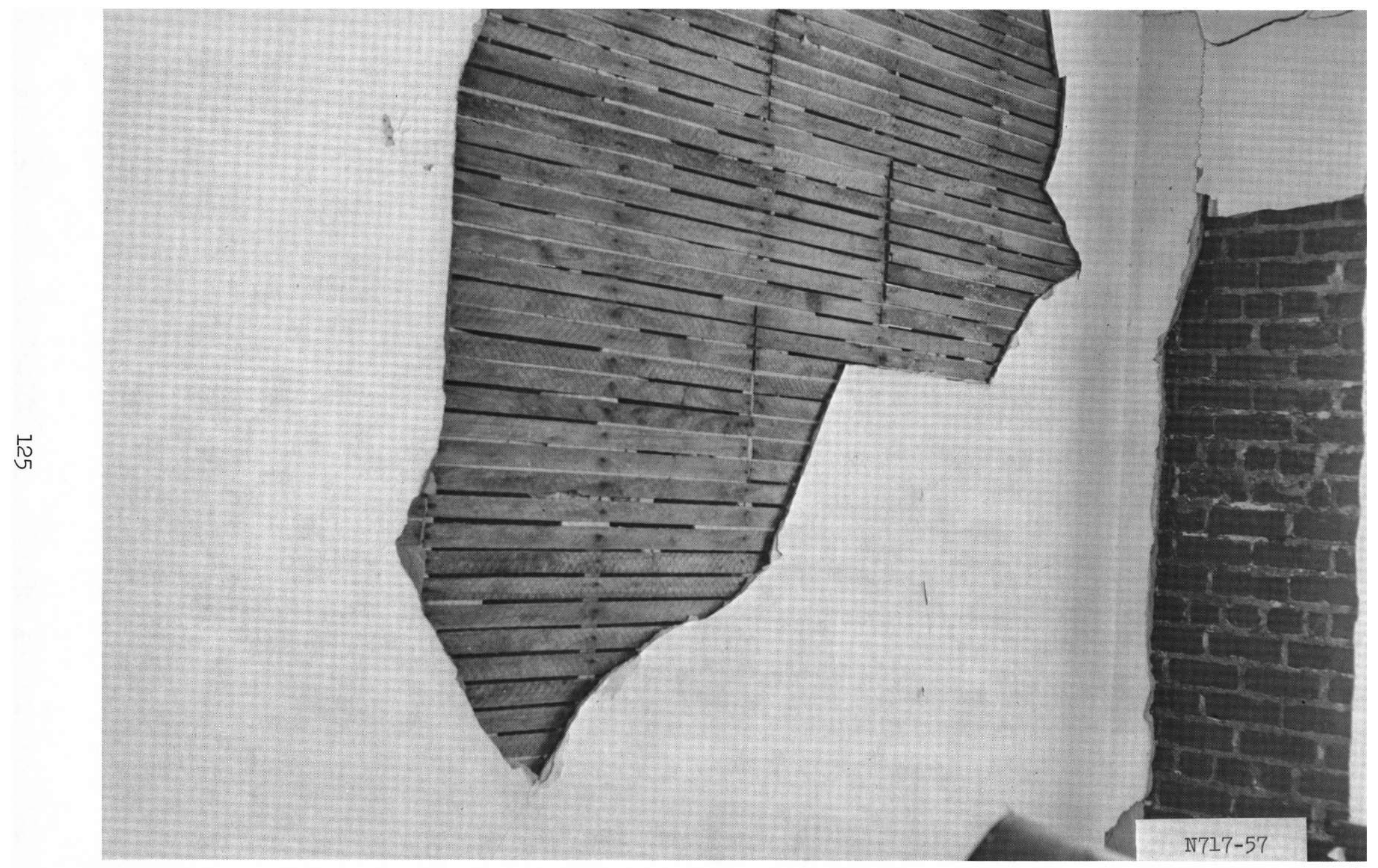

Figure 3.36 Wall damage, Pass Christian City Hall. 


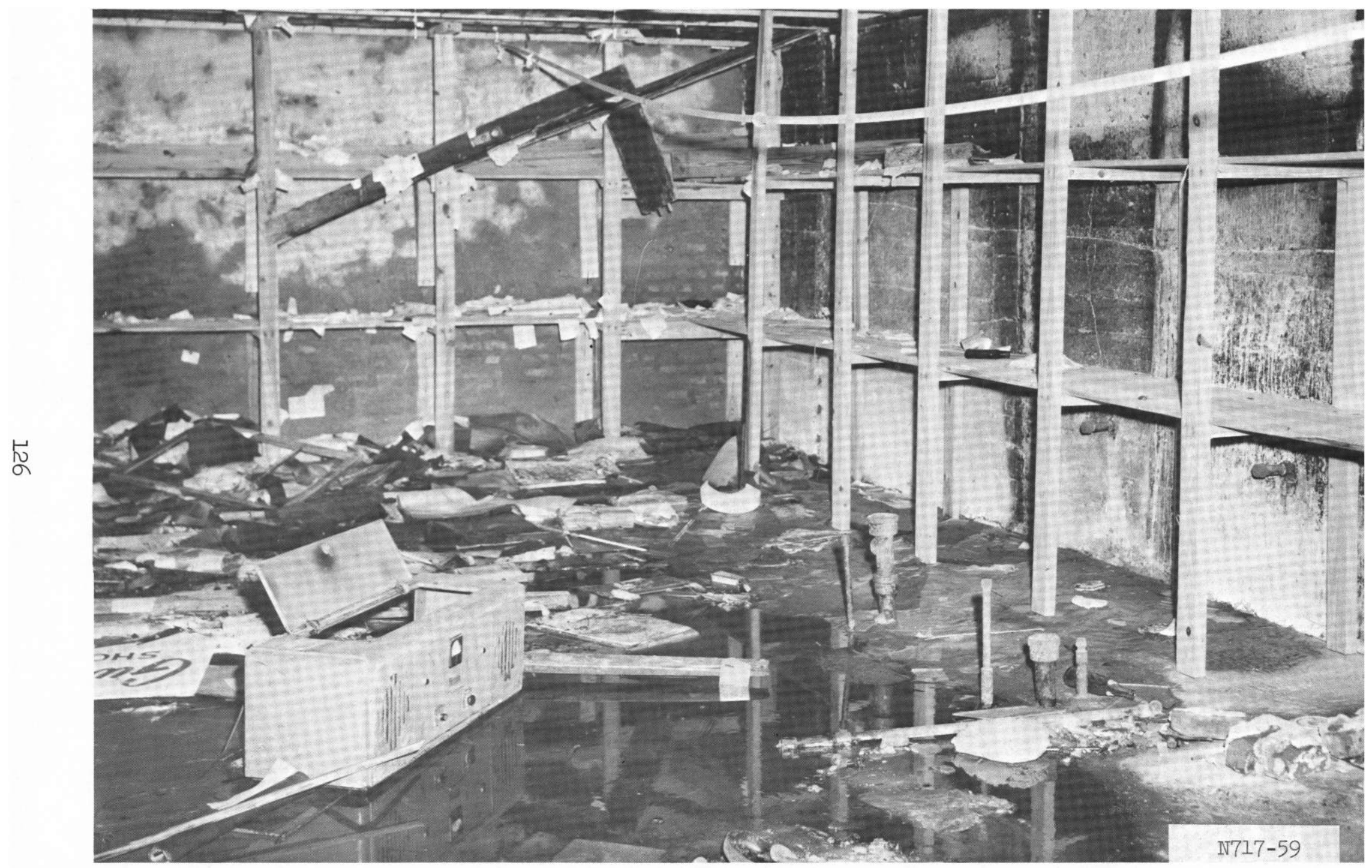

Figure 3.37 Emergency Operating Center, Pass Christian City Hall. 


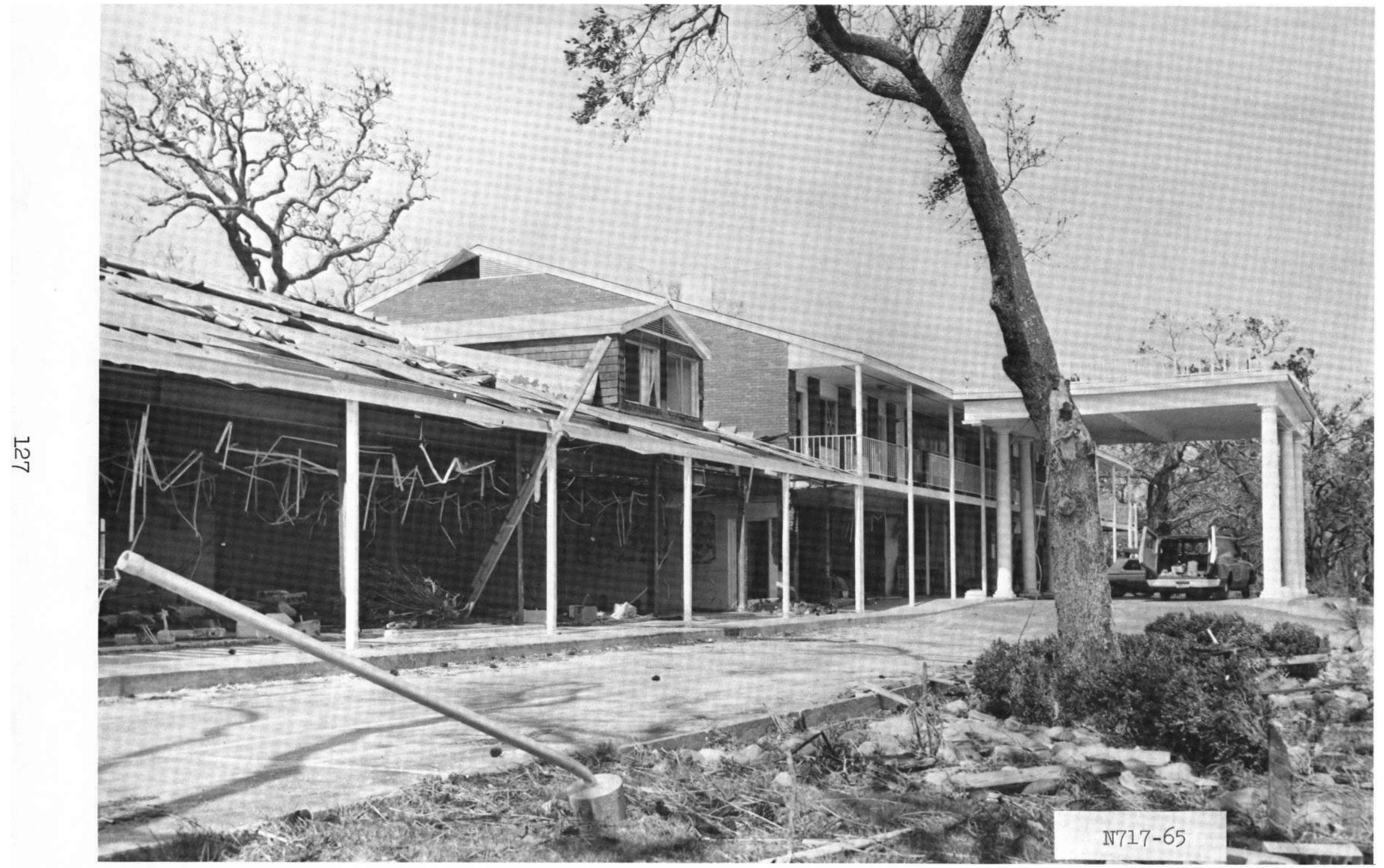

Figure 3.38 Ramada Inn, Long Beach. 


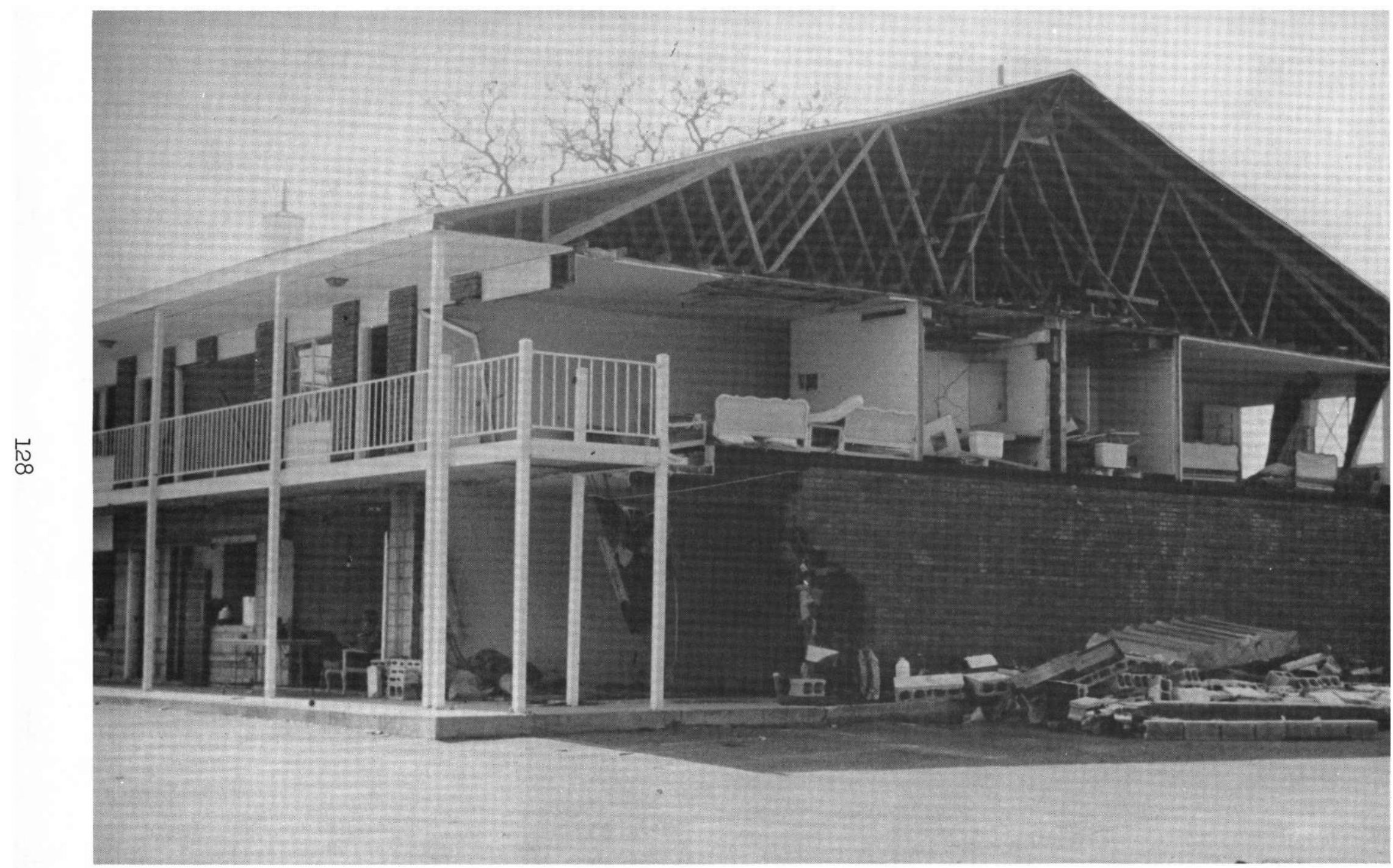

Figure 3.39 East wall of Ramada Inn main building. 


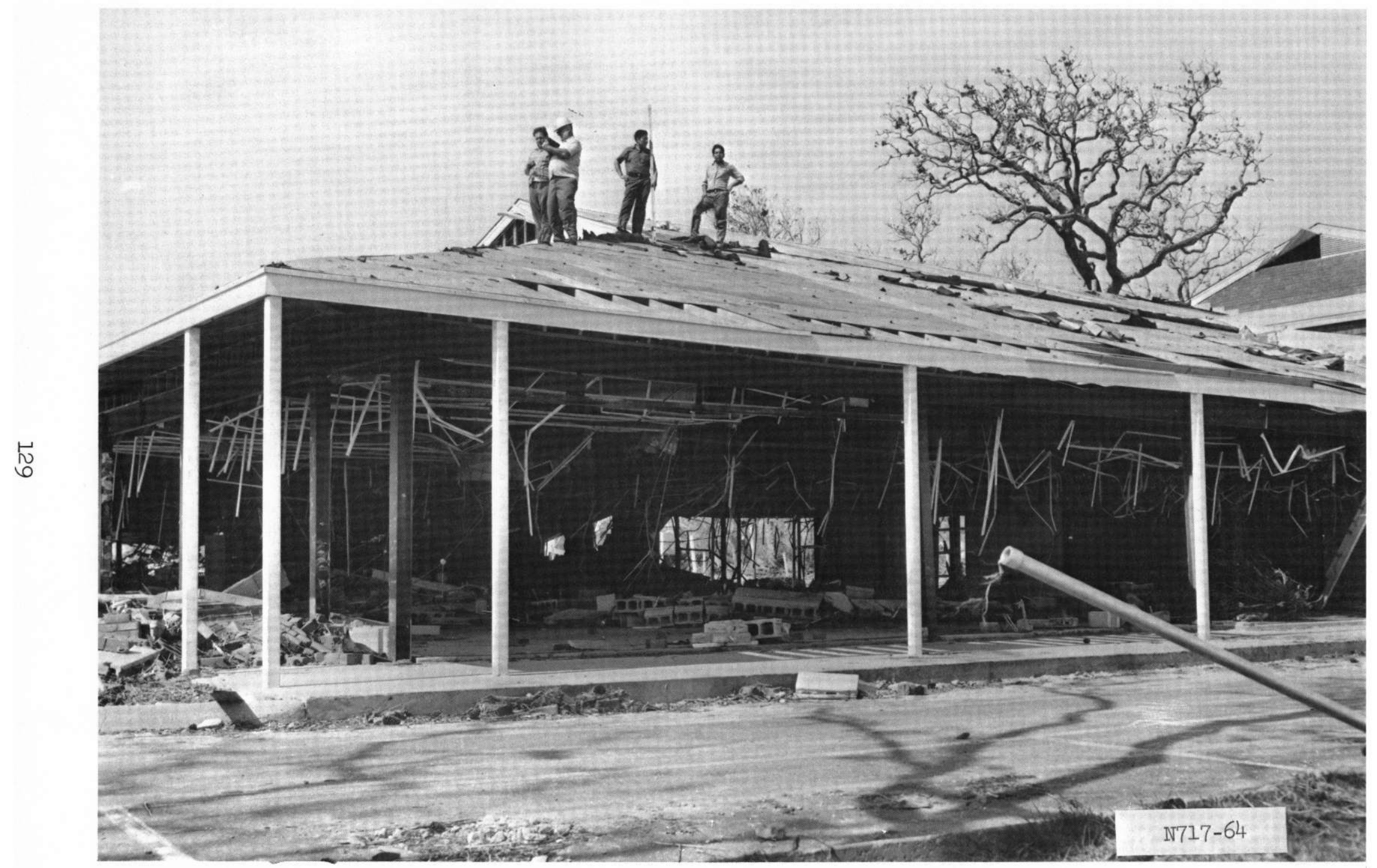

Figure 3.40 Ramada Inn dining area. 


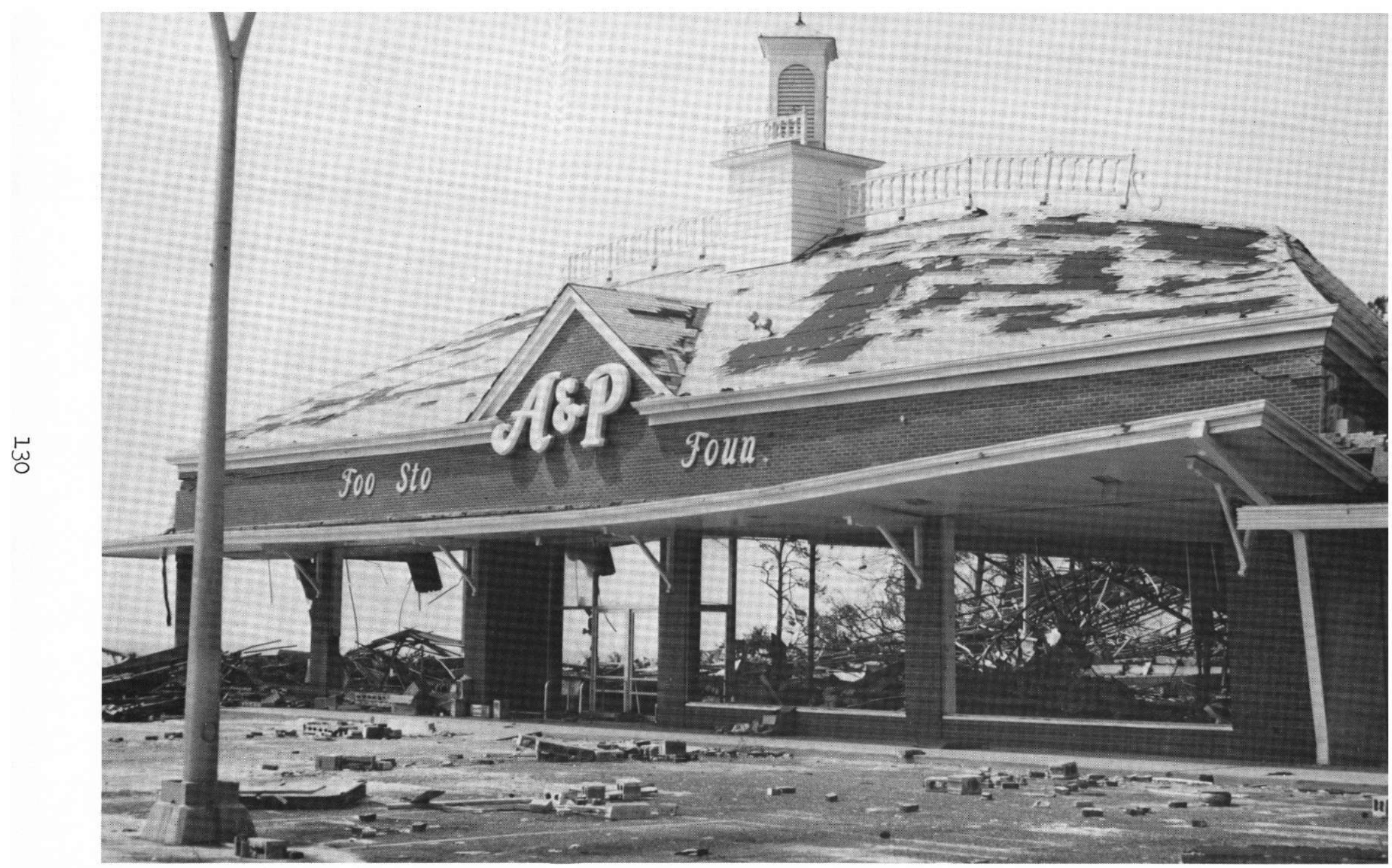

Figure 3.41 Front of A\&P store, Long Beach. 


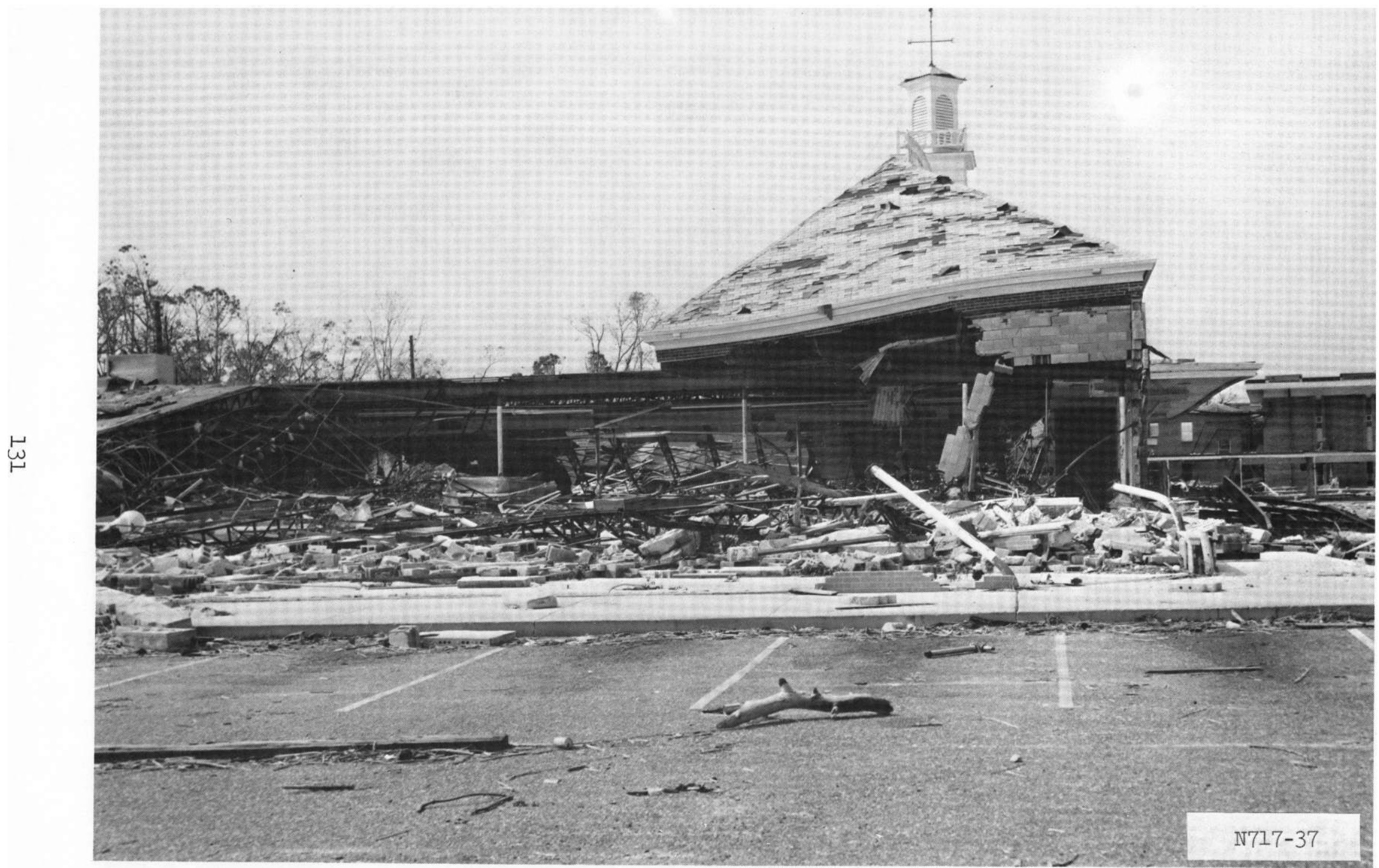

Figure 3.42 Side view of A\&P with remains of Walgreen's in foreground, Long Beach. 


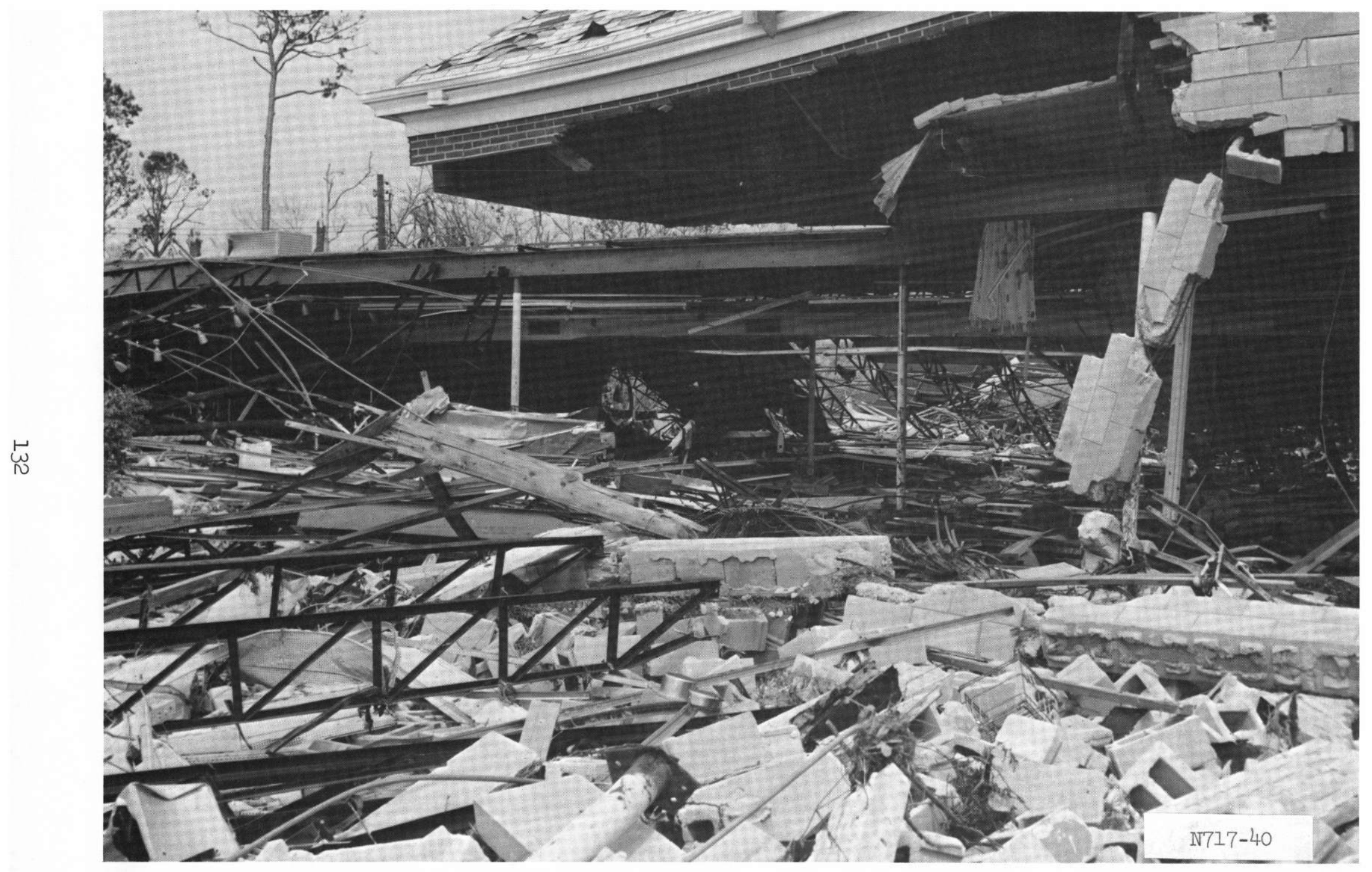

Figure 3.43 Debris in A\&P and Walgreen's stores. 


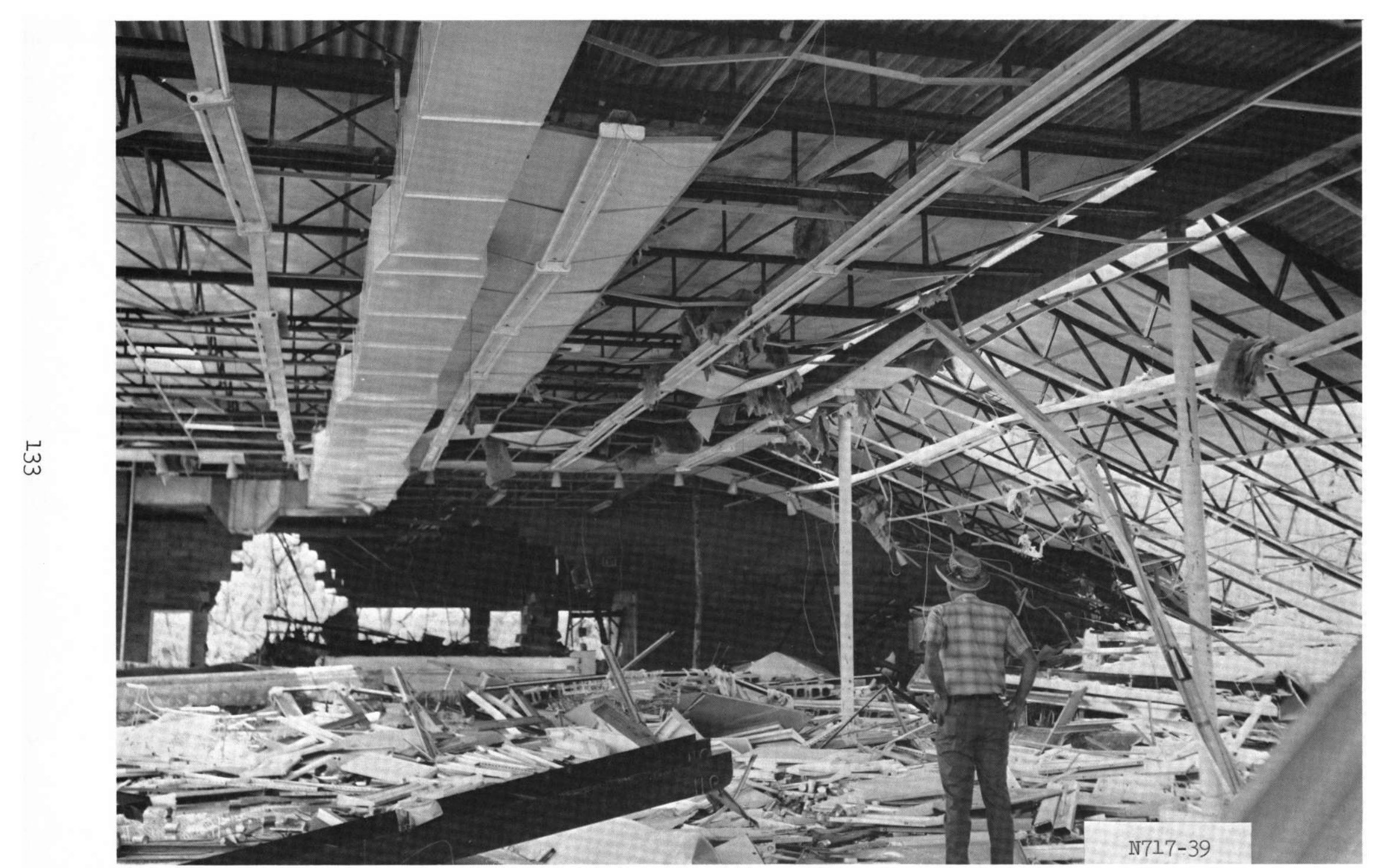

Figure 3.44 Central bay of A\&P, Long Beach. 


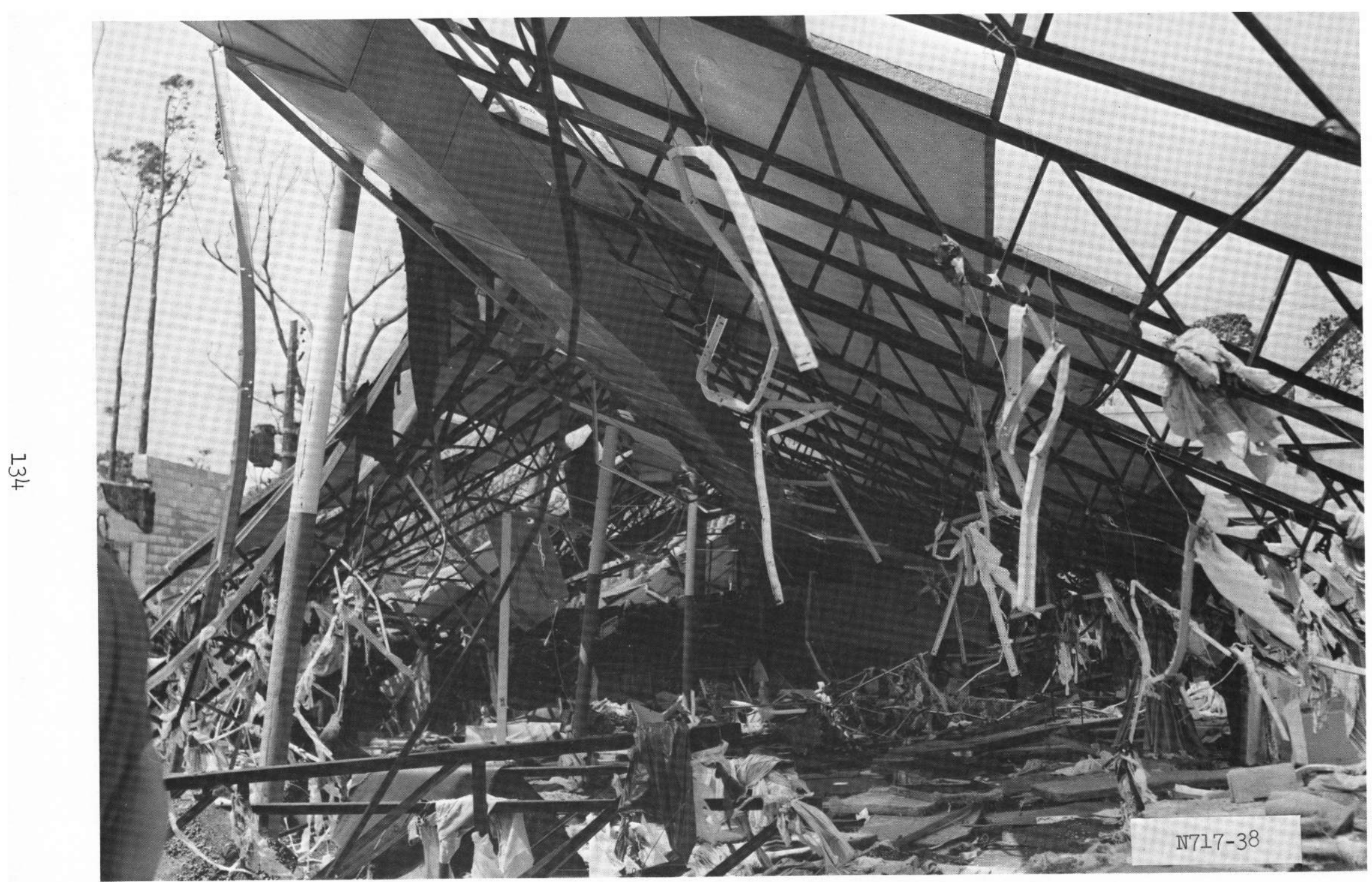

Figure 3.45 Morgan \& Lindsey store, Long Beach. 


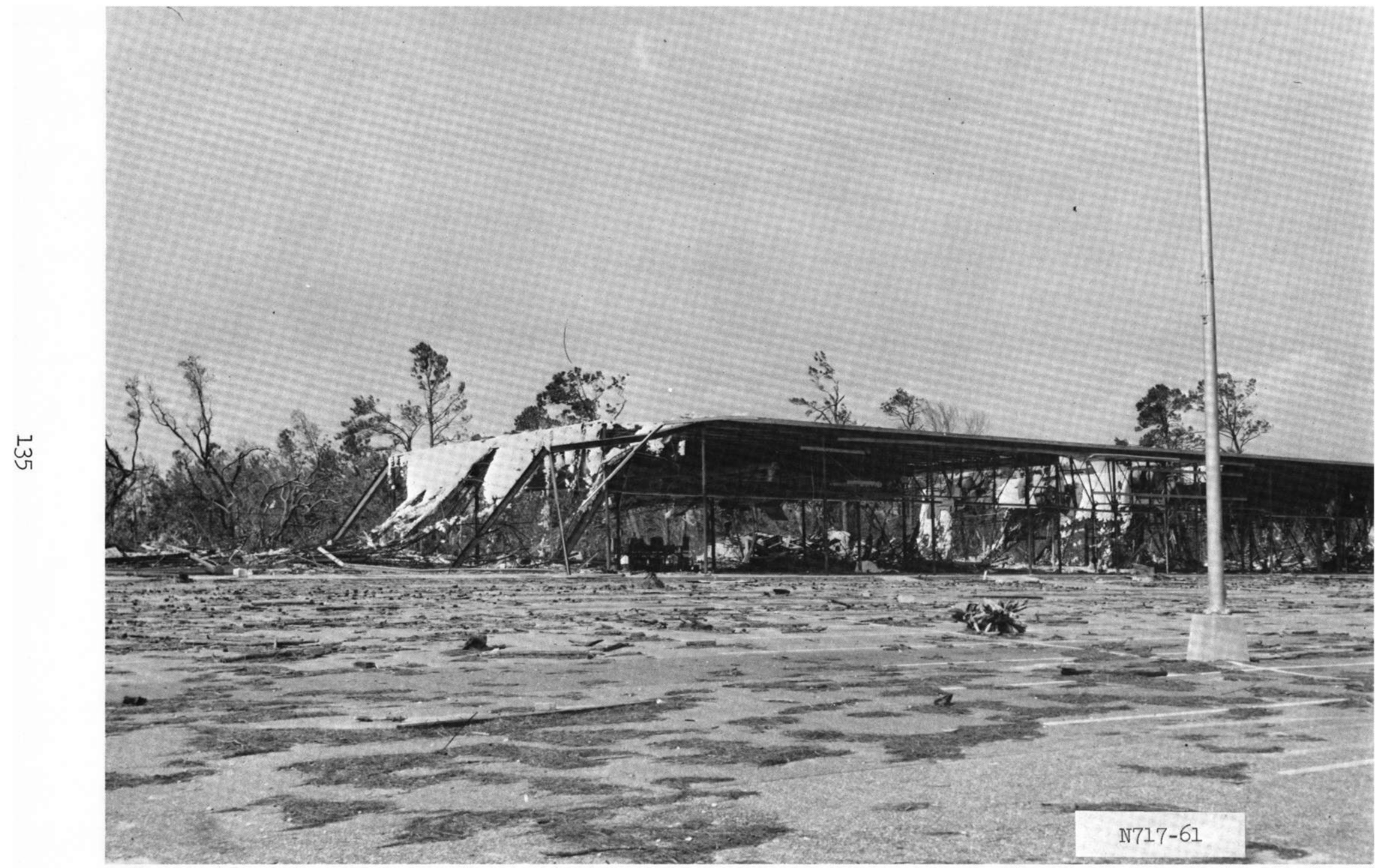

Figure 3.46 Gulf Plaza shopping center. 


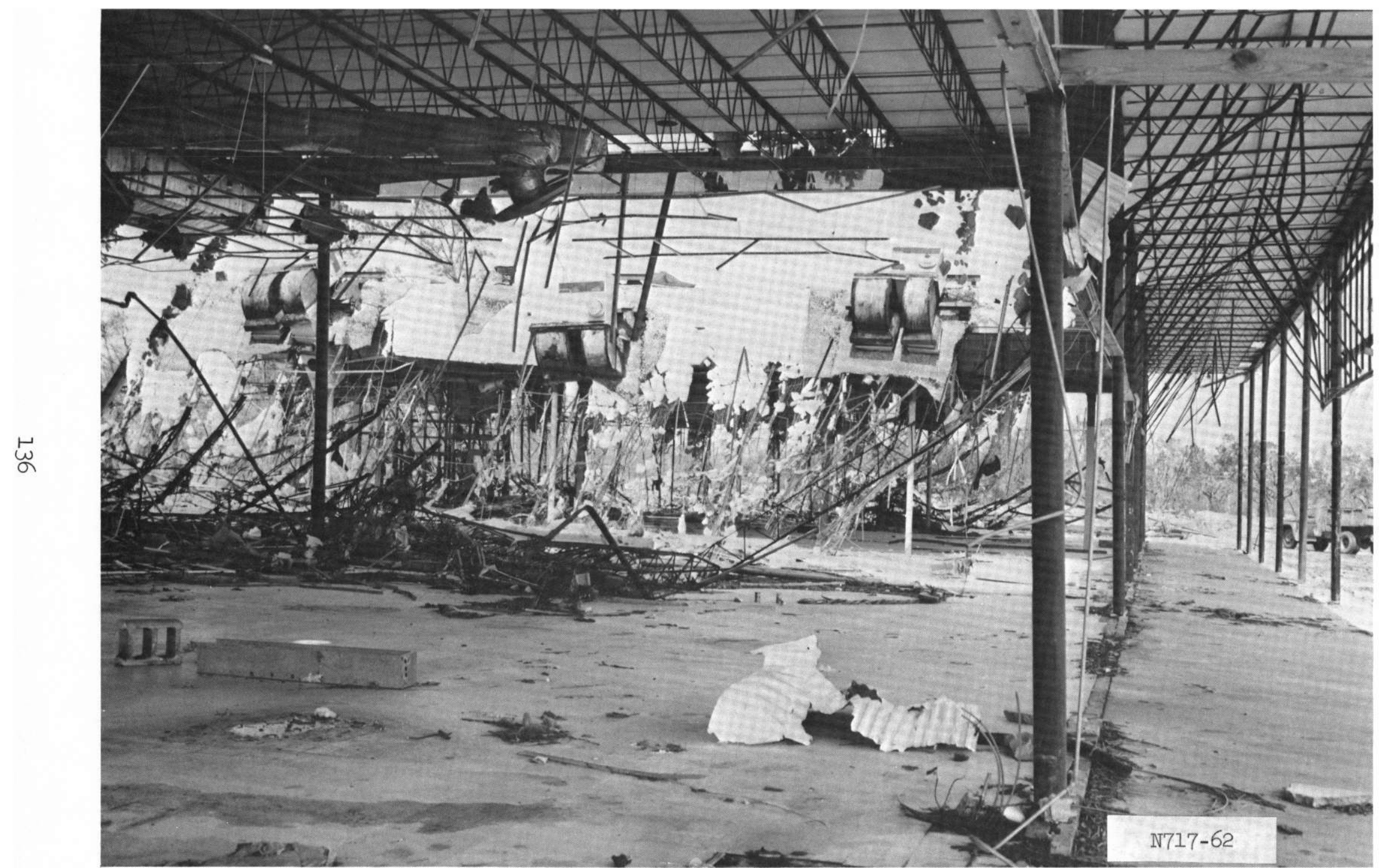

Figure 3.47 Interior of Gulf Plaza shopping center. 


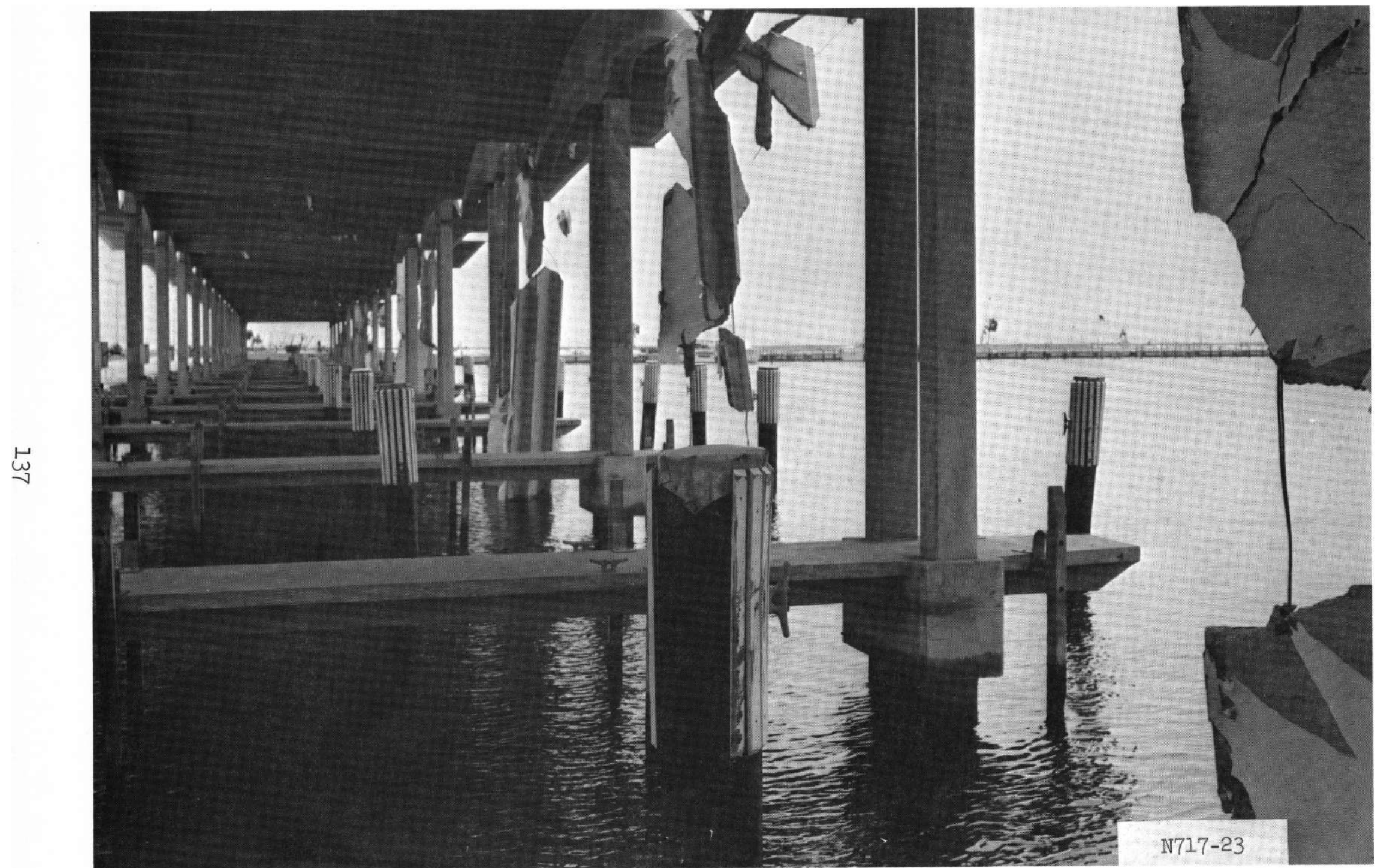

Figure 3.48 Broadwater Beach marina. 


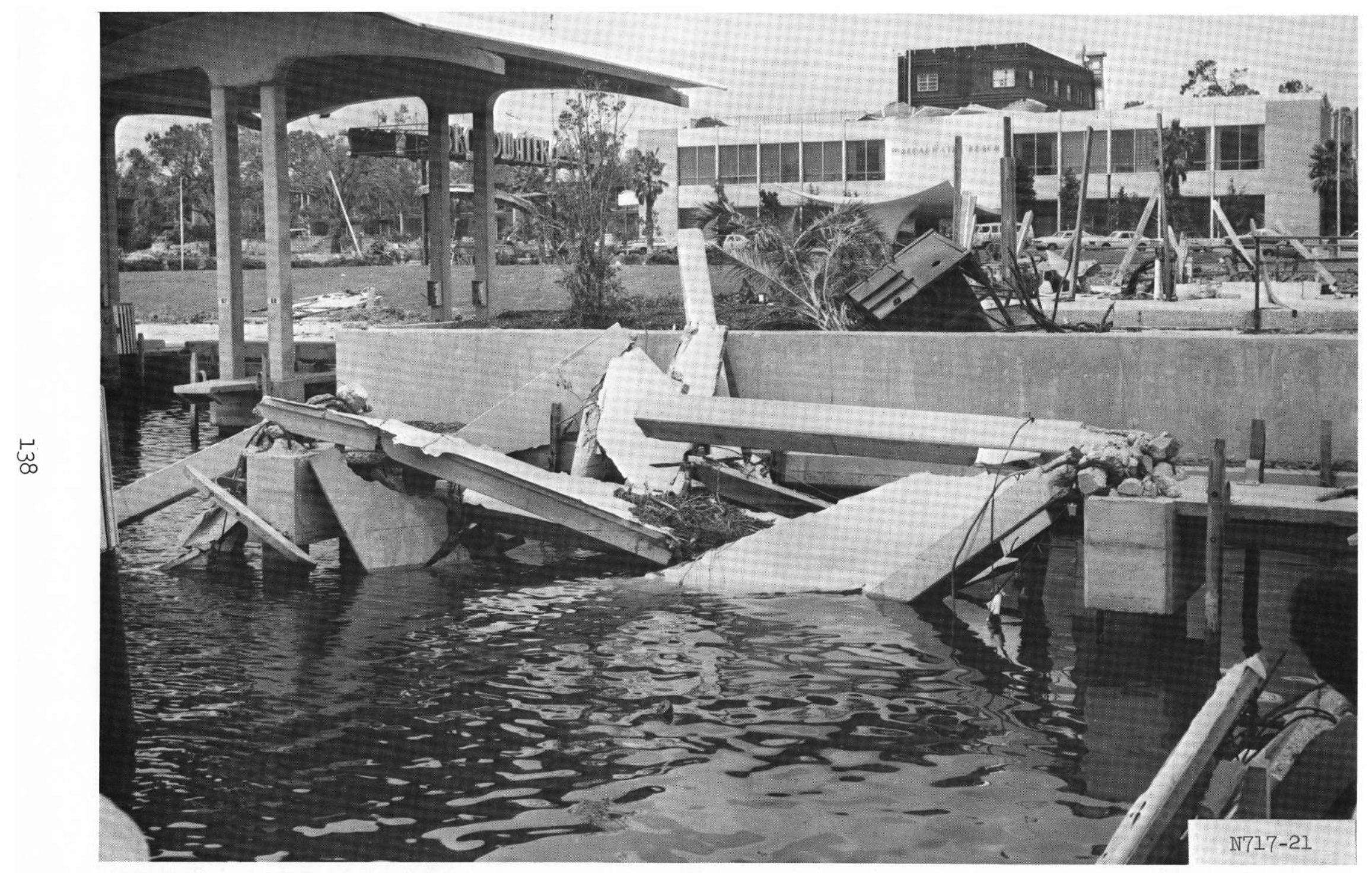

Figure 3.49 Northeast corner of Broadwater Beach marina, looking north. 


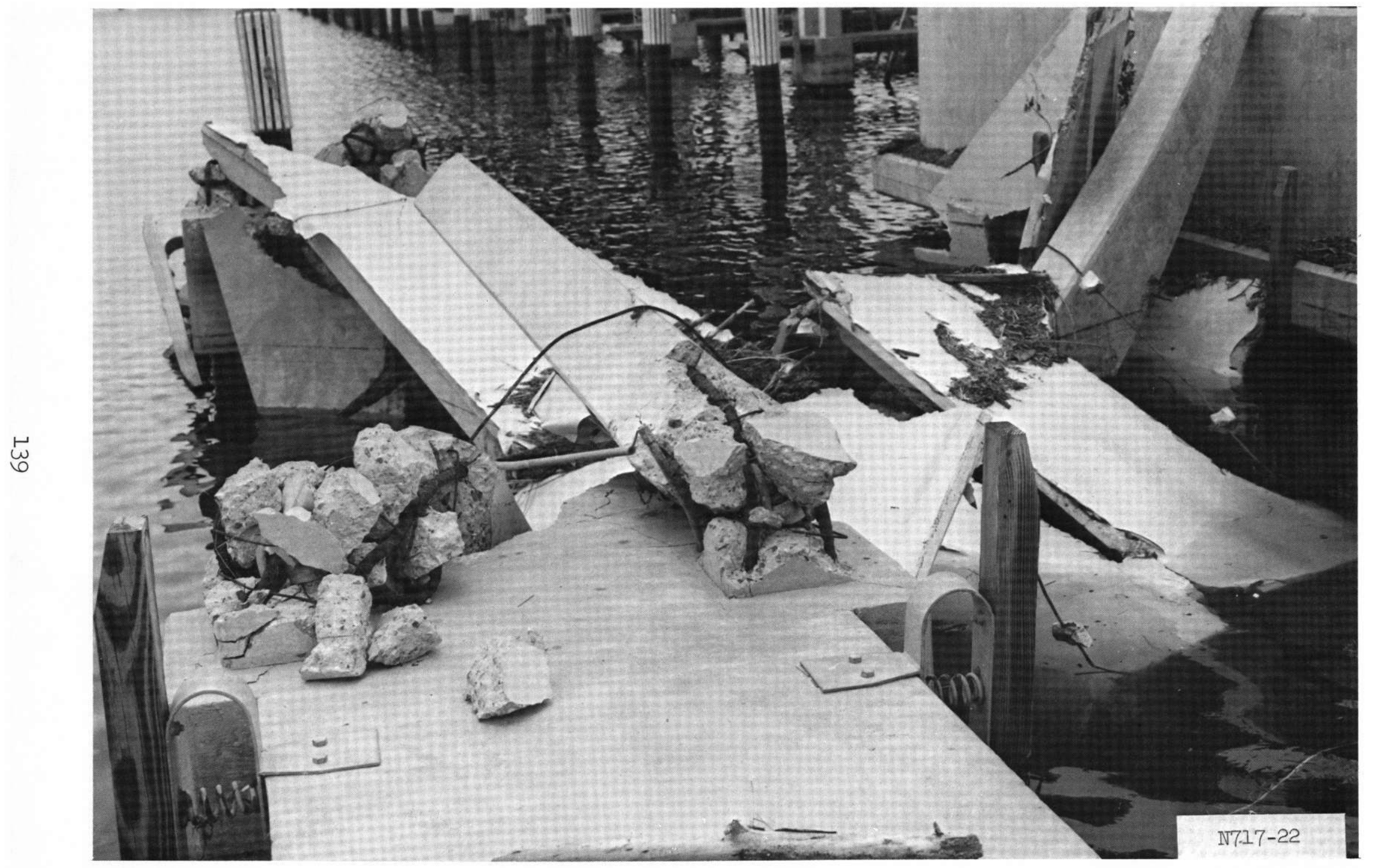

Figure 3.50 Northeast corner of Broadwater Beach marina, looking west. 


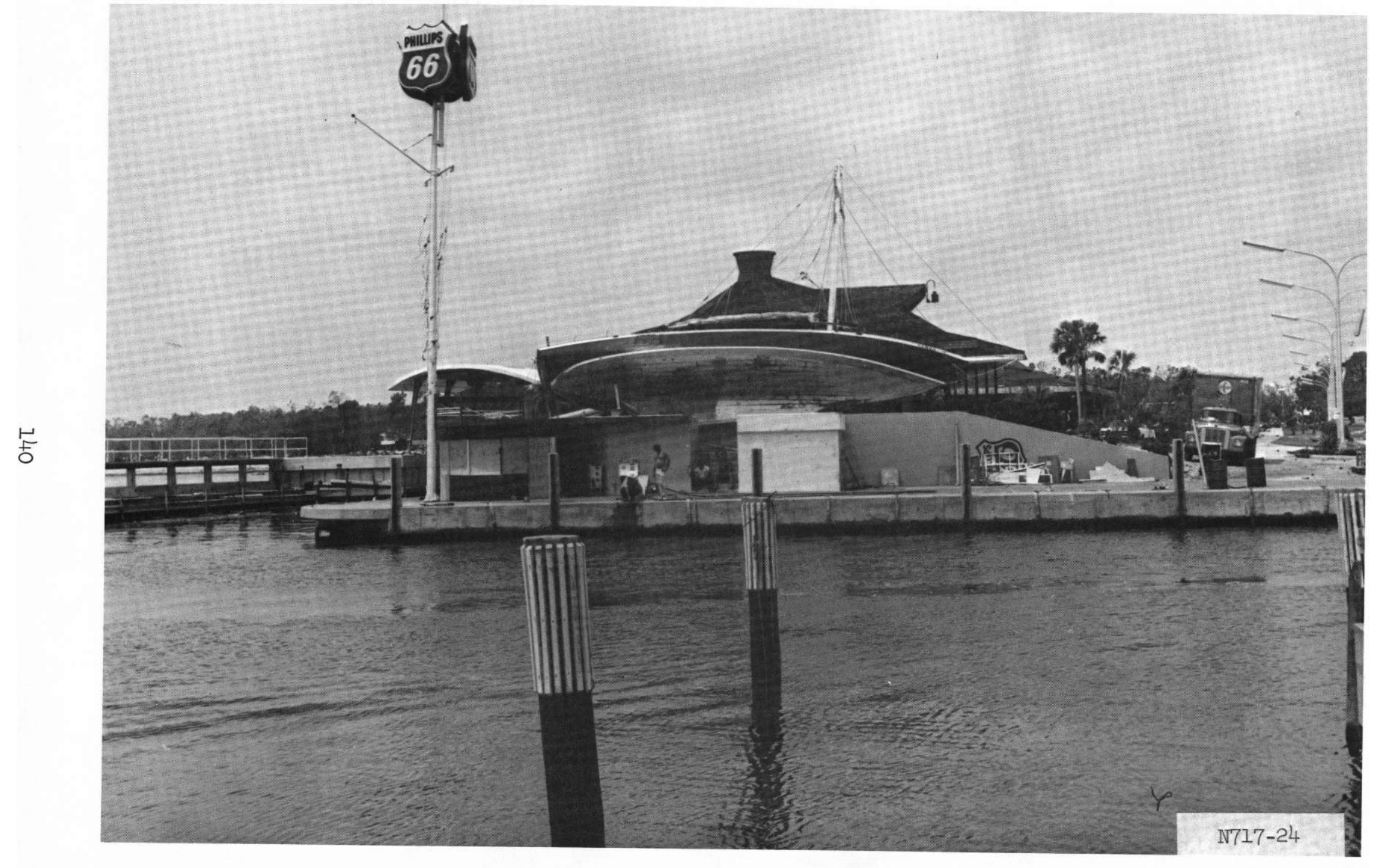

Figure 3.51 Sailboat on Edgewater Beach marina office area. 


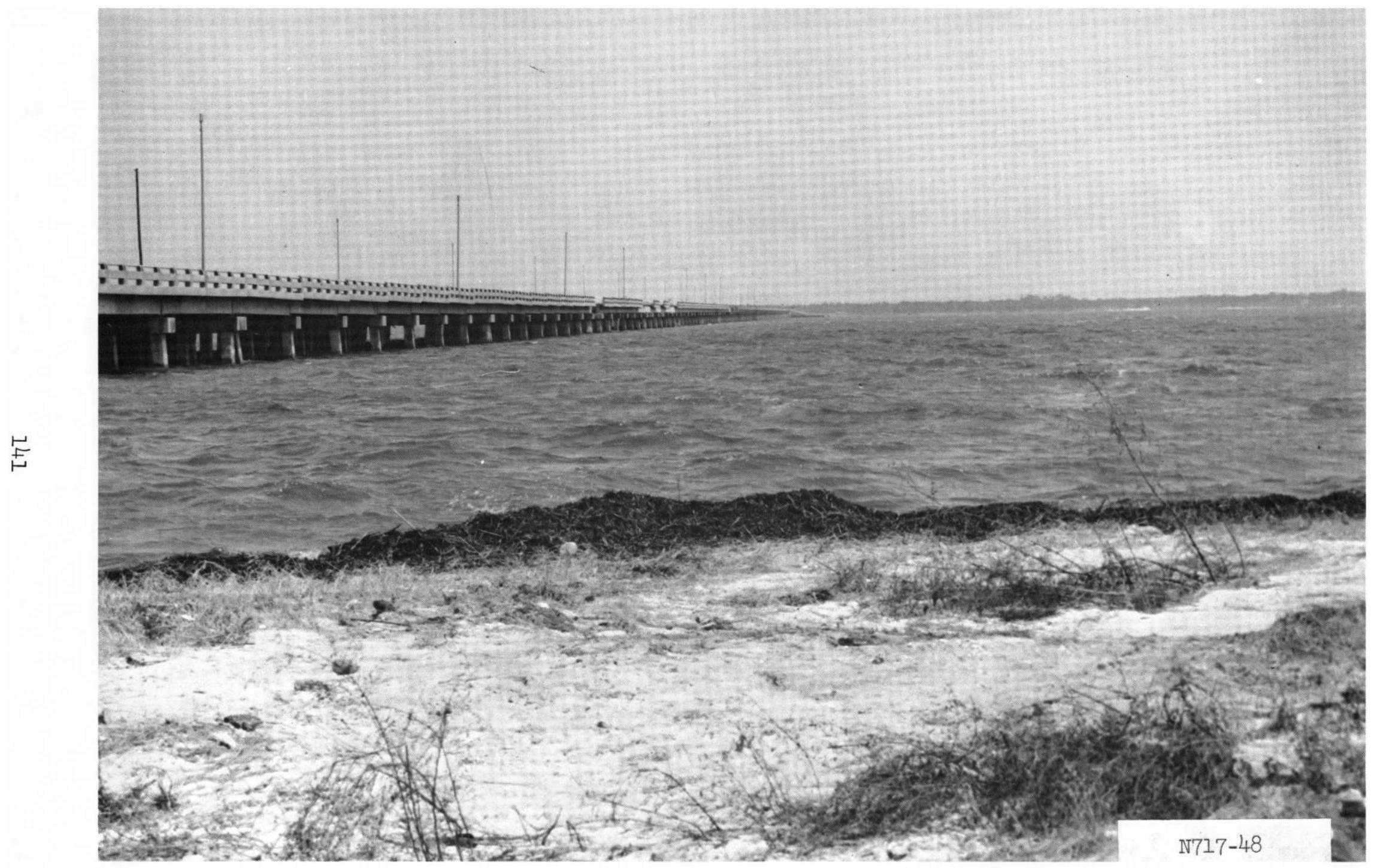

Figure 3.52 Bay Saint Louis Bridge, looking east. 


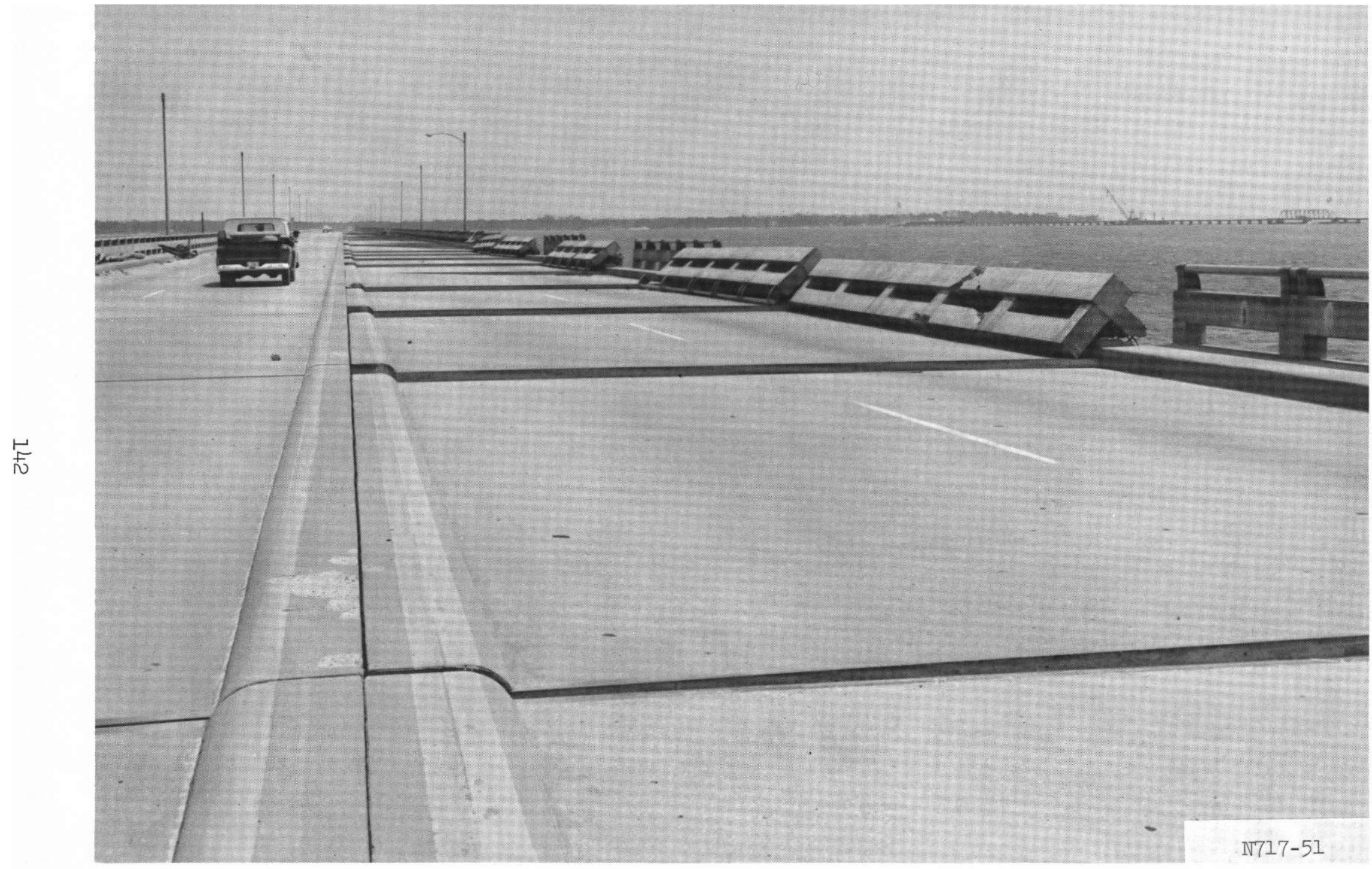

Figure 3.53 Deck of Bay Saint Louis Bridge, looking east. 


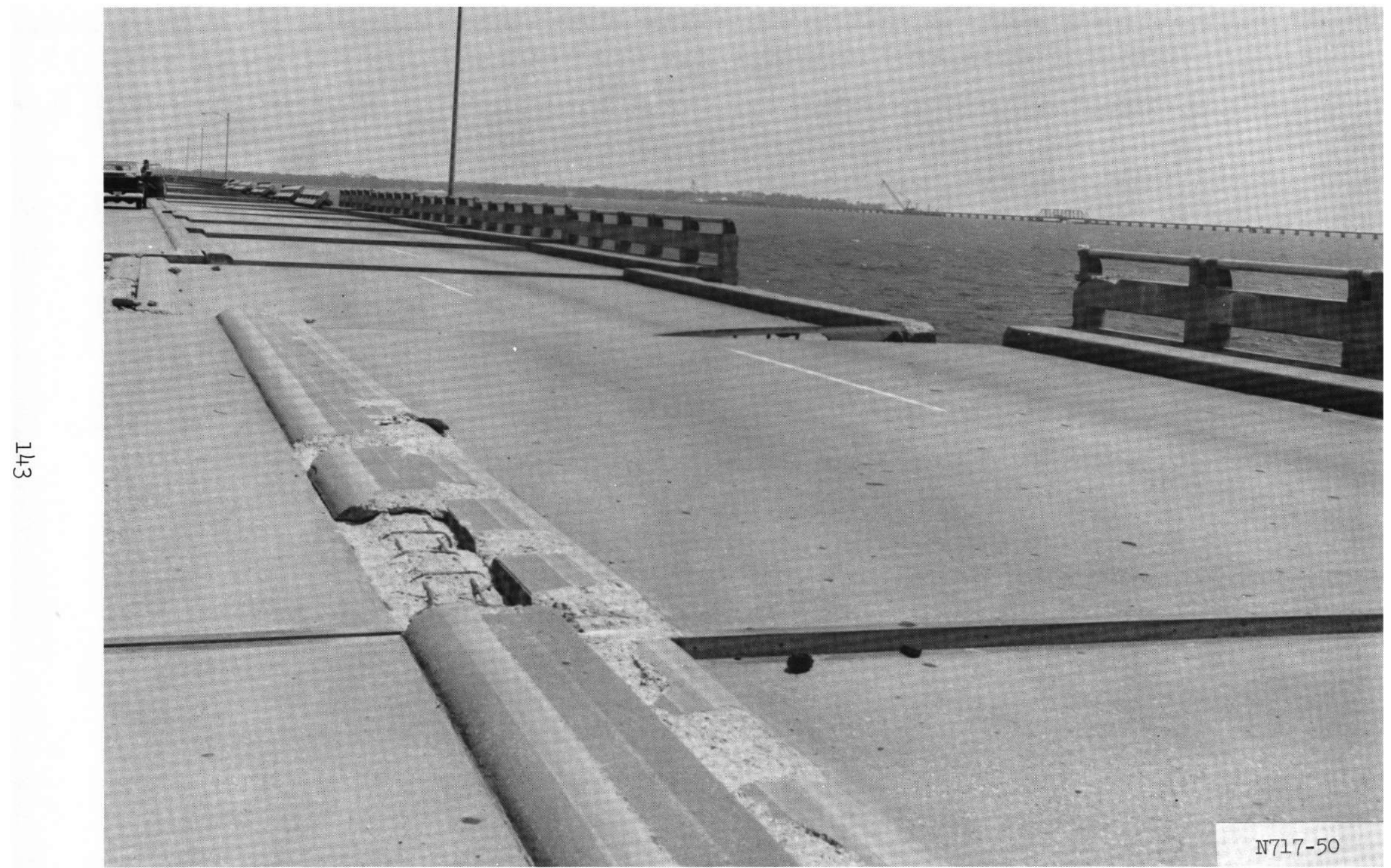

Figure 3.54 Displaced span of Bay Saint Louis Bridge. 


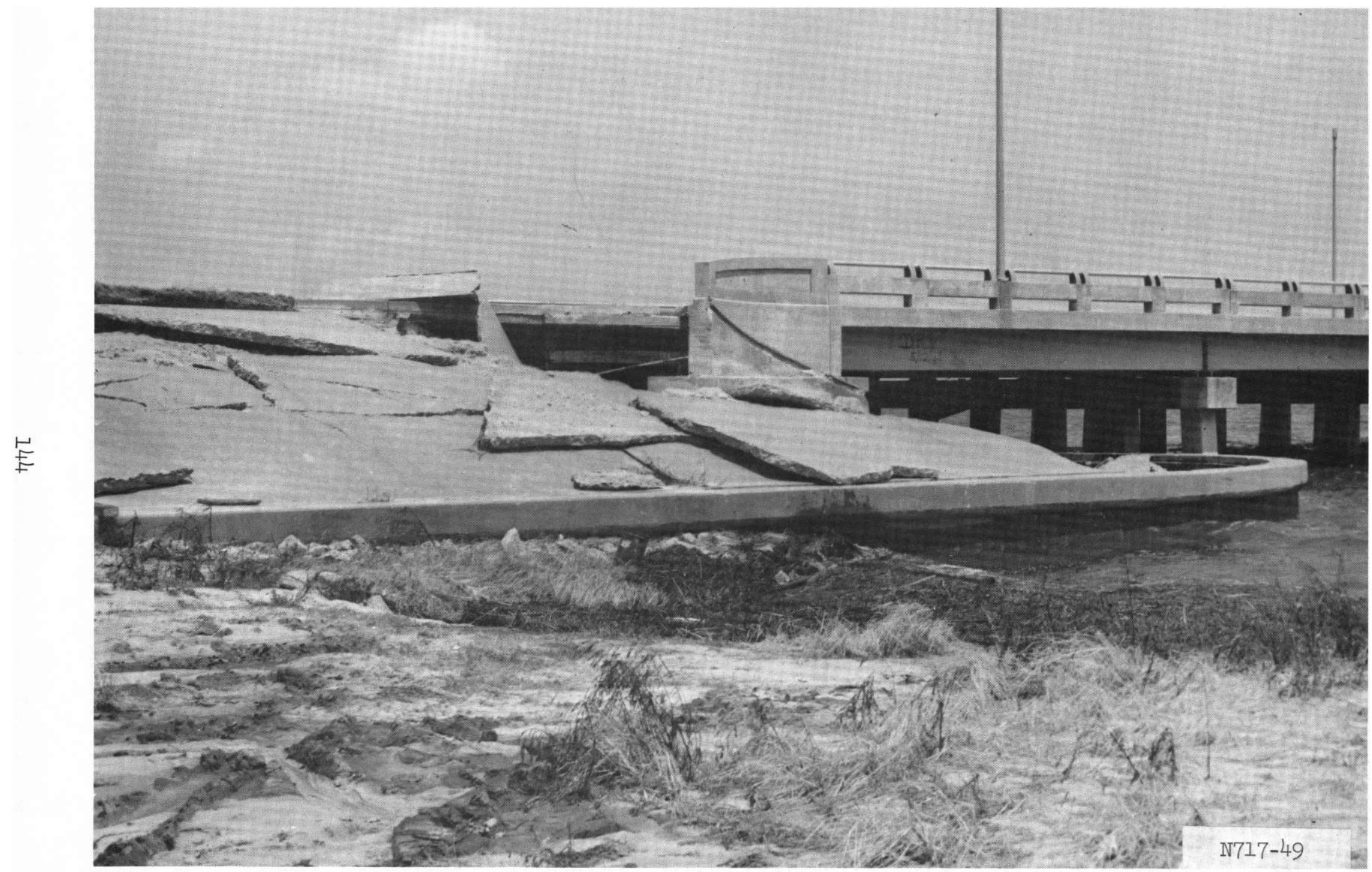

Figure 3.55 West abutment of Bay Saint Louis Bridge. 
CHAPTER 4

DAMAGE TO COMMUNICATIONS, UTILITIES, AND AGRICULTURE

\subsection{HIGHWAYS}

Almost all of the highways were initially impassable because of large amounts of debris, sand, and fallen trees. Considerable amounts of sand were washed over parts of U. S. 90 along the coast.

Highway 90 along the west side of Bay Saint Louis was seriously undercut by wave erosion and washed away in places (Figure 4.1) even though the highway was at an estimated elevation of 20 feet.

The seaward two lanes (east-bound lanes) of U. S. 90 along the coast were heavily damaged by water erosion, especially in the Pass Christian and Long Beach areas. Much of the soil between the seawall and the highway washed out, causing portions of the highway to collapse (Figures 4.2 and 4.3). The inland two lanes were passable at the time of this inspection trip.

Some of the access roads north and several feet above U. S. 90 from Gulfport west were destroyed by water erosion.

\subsection{UTILITIES}

Damage to overhead lines was caused almost entirely by trees and other debris falling on the lines and poles. The poles themselves were only very rarely blown over from the wind directly. Many poles away from trees can be seen standing in Figures 3.14, 3.18, and 3.24.

Some gas mains along U. S. 90 were uncovered by water erosion. Telephone, electric, and gas service were all knocked out by the storm over large areas. The loss of the primary power supply also slowed restoration of water and other services. Numerous operating gasoline-powered generators with OCD markings were seen by the inspection team, especially in the Pass Christian-Long Beach area.

Many gas and water lines were broken in damaged or destroyed buildings and had to be shut off from the lines before these services could be restored. 


\subsection{SANITATION}

Waste water along with storm munoff and sea water was standing on $U$. $S$. 90 in several locations where storm drains were clogged with sand.

The local water supplies were not functioning or were contaminated after the storm. In some cases, water and sewage treatment plants were heavily damaged.

The team noticed that the debris from grocery store meat and produce counters was a serious sanitation problem not yet attended to at the time of this inspection trip. The odors from spoiled contents in refrigerators and freezers located in the debris also caused a problem as sometimes it was first thought that these were from the bodies of buried storm victims.

\subsection{TREES AND AGRICULTURE}

Much of the land in southern Mississippi is in forests and farms. Tung and pecan orchards were extensively damaged. Nearly all such trees were down as far north as the Hattiesburg area. Figure 4.4 shows a group of tung trees near Purvis.

An estimated 15 to 20 percent of the pine trees in the coastal counties were blown over, with smaller amounts farther inland. Corn crops as far north as Hattiesburg were completely flattened.

Much damage to structures and utilities and the blocking of many roads resulted from tree and branch blowdown. 


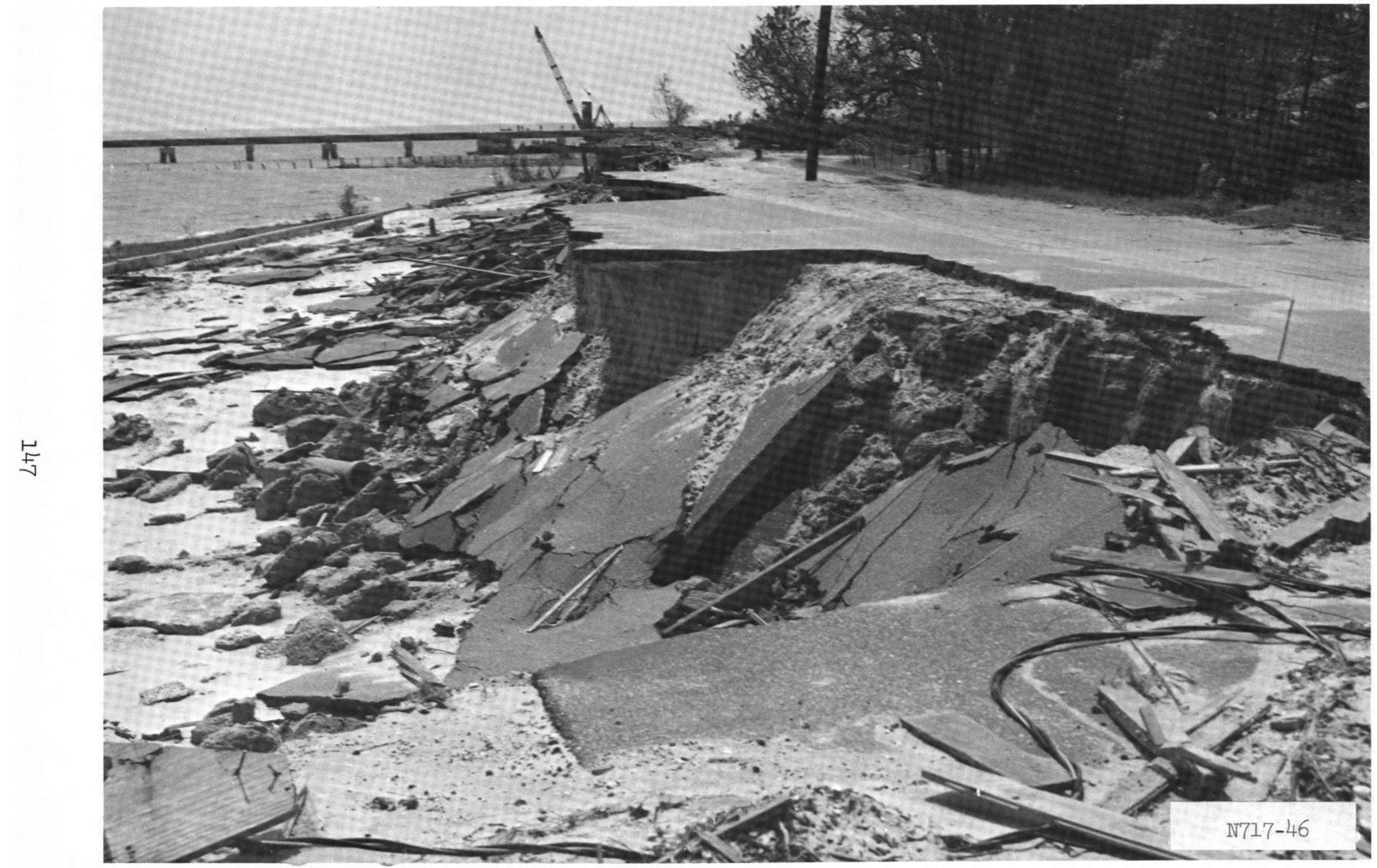

Figure 4.1 U. S. Highway 90 west of Bay Saint Louis. 


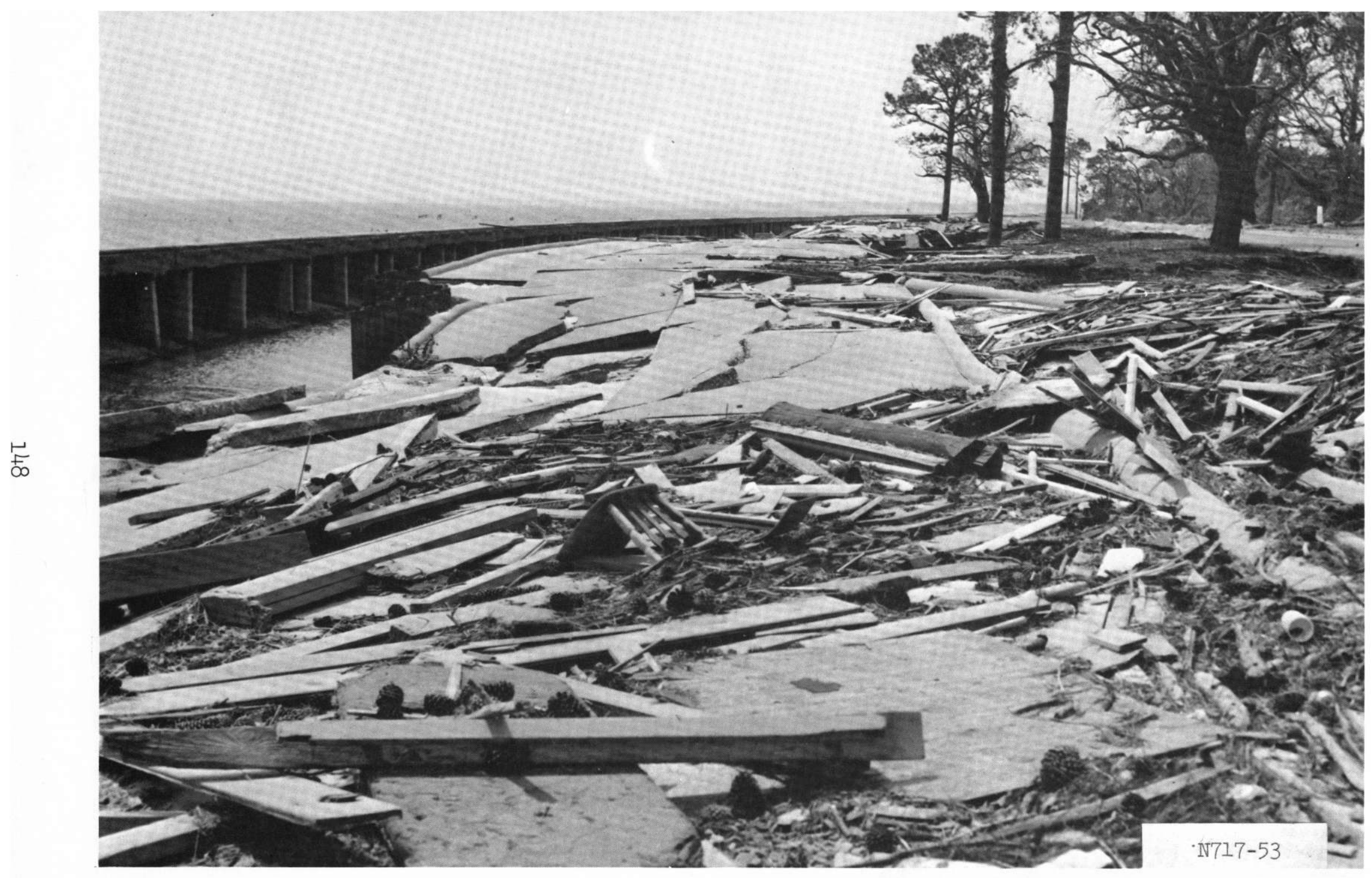

Figure 4.2 U. S. 90 near west end of Pass Christian (east-bound lanes). 


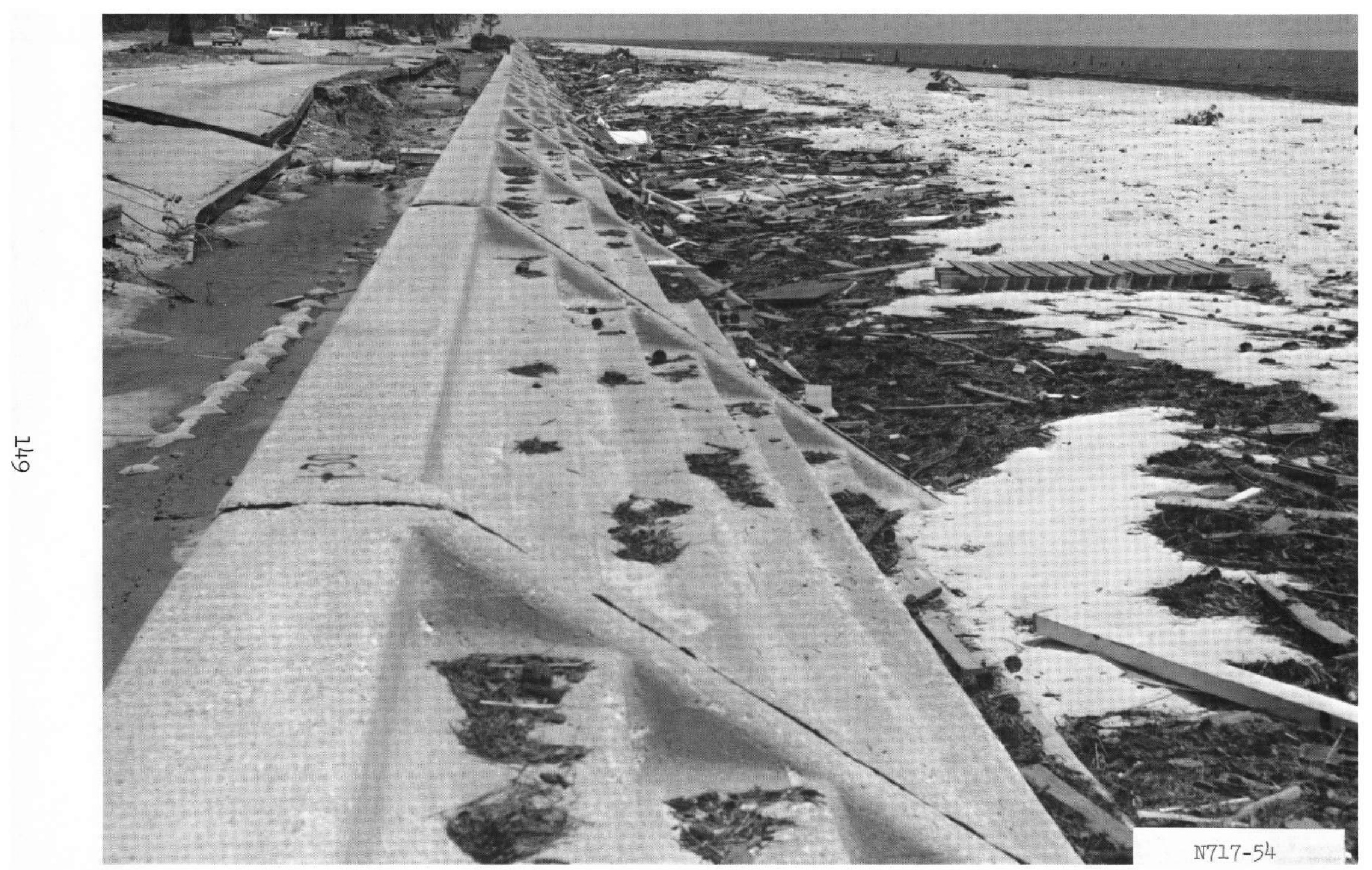

Figure 4.3 U. S. 90 near Pass Christian. 


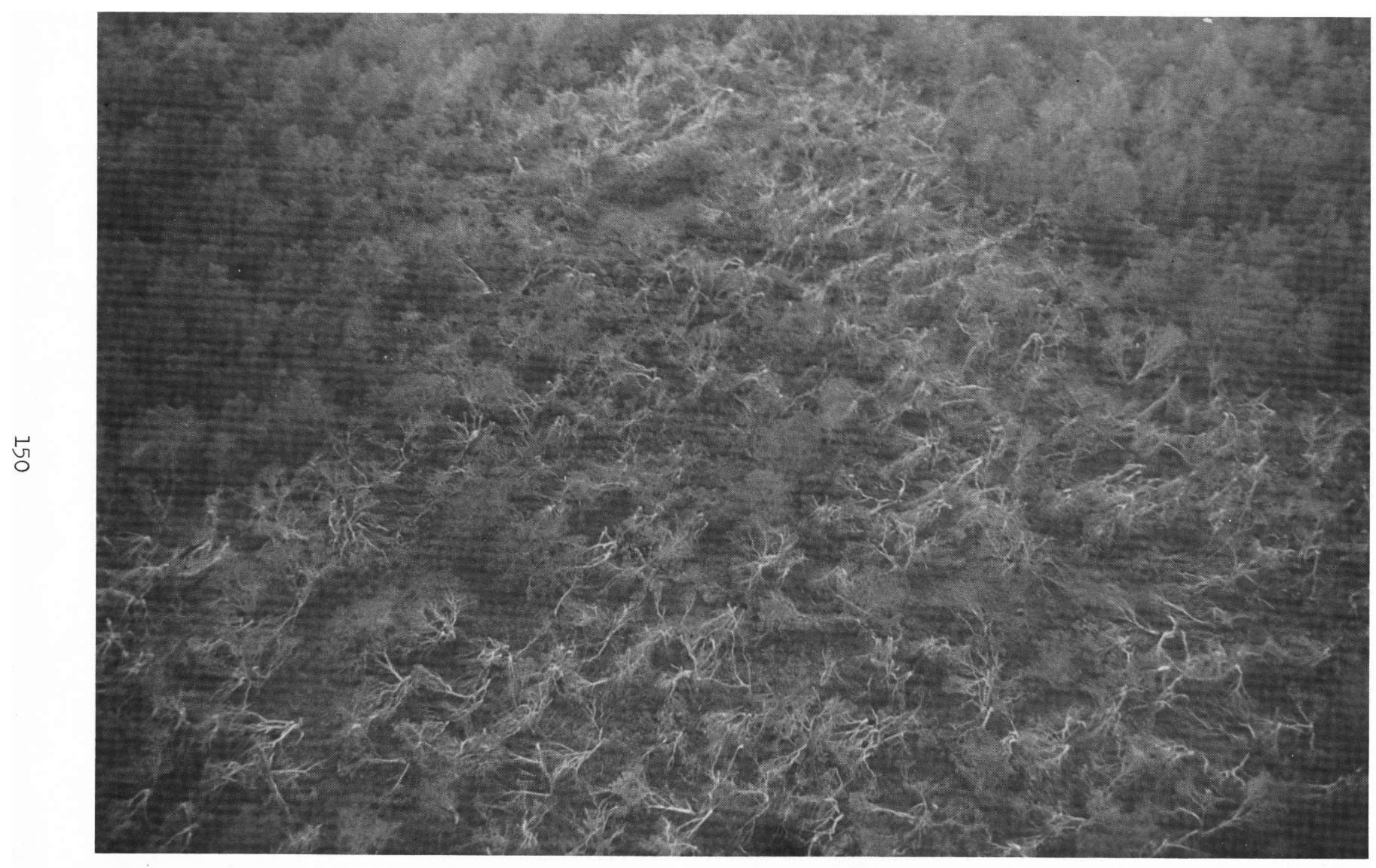

Figure 4.4 Aerial view of damaged tung trees near Purvis, Mississippi. 
CHAPTER 5

SUMMARY, CONCLUSIONS, AND RECOMMENDATIONS

\subsection{SUMMARY}

Very extensive structural damage was done by Hurricane Camille both in the Mississippi River Delta area of Louisiana and in southern Mississippi. Wind velocities and tides higher than any previously recorded in the Gulf Coast area accompanied the storm.

The most intense areas of destruction were immediately adjacent to the Gulf of Mexico and appeared to have resulted primarily from water and winddriven wave action. Any evidence of direct wind damage in these areas was usually destroyed by the water damage. It is believed that much of the damage in coastal areas could have been prevented only with very heavy construction, very restrictive zoning, by an enormous seawall, or by constructing all buildings with the first floor open, none of which are particularly practical or economical alternatives. The loads acting on many buildings were obviously larger than the design loads for the structures.

Wind damage to structures inland was small compared to that in the immediate coastal areas and less than had been expected.

The only structural damage seen to NFSS spaces was to those located in buildings very close to the seacoast (within the first few blocks). Some others farther inland had water damage to contents.

Tree fall due to wind was a great problem, especially with regard to transportation and utility systems. Chain saws were in very great demand in the storm area. A very significant portion of the structural damage away from the areas of water damage was caused by trees and branches falling onto buildings.

Masonry block structures proved particularly weak in the areas immediately adjacent to the Gulf where wave action was appreciable.

Mobile homes were heavily damaged both along the coast and inland. Several examples of inadequate and/or faulty connections and construction details were seen. 


\subsection{CONCLUSIONS}

The magnitudes, types, and durations of the loads acting upon the structures in the storm area are known only approximately. In many cases immediately along the seacoast, it appeared that wind was the critical loading on roofs and upper floors, while water and wave-generated loads were probably critical nearer the ground.

Because of the unknown loading histories, detailed analysis of the structures to obtain meaningful quantitative information concerning the strength and performance of the buildings located in the storm area will be most difficult. The storm damage did yield meaningful information on the weak points of buildings, the collapse mechanisms, and the relative strengths of various building types.

Three general conclusions reached concerning the performance of structures during this storm are:

I. Many buildings, especially masonry structures, are much too dependent on vertical forces (including deadweight) for their stability and have little strength when the loading is not vertical (lateral loads).

2. The connections and details so necessary in tying a structure together are too often inadequate. This can result from both inadequate design and poor construction.

3. The possibility of hurricane-caused loadings, even from storms much smaller in intensity than Camille, did not appear to have been recognized in the design of a great number of the more recent buildings constructed along the Gulf Coast.

The maximum 190-mph winds in the storm area correspond to a pressure loading of 0.8 to $0.9 \mathrm{psi}$. The storm damage cannot, however, be directly compared with that to be expected at this pressure level of a nuclear blast. First, much of the storm damage was caused by moving water or by water and wind in combination. This type of loading generally would not accompany blast loading. Second, several important loading phenomena accompanying a nuclear blast, especially the overpressure (or diffraction) loading with its nearly instantaneous rise time and any ground motion, were absent. The wind loading resulting from the storm corresponds only to the dynamic (wind) pressure loading phase of the loading from a nuclear blast. 


\subsection{RECOMMENDATIONS}

More attention should be given to construction details and inspection. In many cases, more attention to these "small" items would greatly increase the structural strength with little additional cost. Highquality inspection during construction should, of course, be encouraged.

Masonry walls should be required to contain some reinforcement, especially in the bottom-story walls of construction located near coastlines. The use of masonry bearing walls in construction near coastlines with a hurricane history may need to be controlled (building codes).

Roof trusses and bar joists should be adequately connected at their ends to the supporting element. Use of very small or tack welds should not be permitted. Setting of trusses and joists only into masonry walls should be discouraged. Trusses, frames, and joists should be given adequate lateral support.

Well written and rigidly enforced building codes are needed in areas of potential storm damage to help prevent appreciable damage from most tropical storms and to minimize damage from unusual storms such as Camille. It should be realized, however, that it is most probably not economically feasible to require all buildings along the Gulf and lower Atlantic coastlines to be constructed so that they can survive undamaged such intense storms as Camille.

It is of direct interest to OCD and to the engineering profession to encourage the writing, adoption, and enforcement of building codes which will increase the inherent strength of construction, especially against lateral loads. Much construction can be feasibly "slanted" toward increased blast resistance by OCD only in this way. The structural adequacy of conventional construction will greatly affect the survival of structures and any occupants in the 1/2- to 5-psi overpressure zone of a possible nuclear detonation. 
1. R. M. DeAngelis; "Furricane Camille - August 14-22, 1969"; Weekly Weather and Crop Bulletin, 1 Sept 1969, Vol. 56, No. 35; U. S. Weather Bureau, Washington, D. C.; Unclassified.

2. K. V. Wilson and J. W. Hudson; "Hurricane Camille Tidal Floods of August 1969"; U. S. Geological Survey, Fydrological Investigations, Atlas HA-395 through HA-408, 1969; Unclassified.

3. U. S. Weather Bureau, New Orleans; "Hurricane Camille . . Gulf of Mexico . . ., August 14-18, 1969"; (Memorandum Report); Unclassified.

4. Committee Report; "Wind Forces on Structures"; Task Committee on Wind Forces, Committee on Loads and Stresses, Structural Division; Transactions, ASCE, 1961, Vol. 126, Part II, Pages 1124-1198; Unclassified. 
Addressee.

No. of Copies

Office of Civil Defense

Office of the Secretary of the Army

Attn: Research Administration Office

Pentagon

Washington, D. C. 20310

Army Library

1A 518, Pentagon

Washington, D. C. 20310

Assistant Secretary of the Army (R\&D)

Attn: Assistant for Research

Washington, D. C. 20310

Chief of Naval Research

Department of the Navy

Washington, D. C. 20360

Commander, Naval Supply Systems Command (Code 0611C1)

Department of the Navy

Wa shington, D. C. 20360

Commander, Naval Facilities Engineering Command

Research and Development (Code 0322C)

Department of the Navy

Washington, D. C. 20390

Mr. Richard Park

Advisory Committee on Civil Defense

National Academy of Sciences

2101 Constitution Avenue, N. W.

Washington, D. C. 20418

Defense Documentation Center

Cameron Station

Alexandria, Virginia 22314

Mrs. Joanne S. Gailar

Civil Defense Research Project

Oak Ridge National Laboratory

P. O. Box X

Oak Ridge, Tennessee 37830 
Mr. Norward A Meador

Shelter Research Division

Office of Civil Defense

Department of the Army - OSA

Washington, D.C. 20310

Chief of Naval Personnel

(Code Pers M 12)

Department of the Navy

Washington, D. C. 20360

U. S. Naval Civil Engineering Laboratory

1

Port Hueneme, California 93041

Director, Disaster and Defense Services Staff

Agricultural Stabilization and Conservation Service

U. S. Department of Agriculture

Washington, D. C. 20250

Mr. Bill Miller

Department of Civil Engineering

307 More Hall

University of Washington

Seattle, Washington 98105

Mr. Carl Koontz

Department of Civil Engineering

Worcester Polytechnic Institute

Worcester, Massachusetts 01609

Mr. Franklin J. Agardy

Department of Civil Engineering

San Jose State College

San Jose, California 95114

Mr. Robert Bailey

School of Civil Engineering

Civil Engineering Building

Purdue University

Lafayette, Indiana 47907

Mr. John A. Samuel

Department of Mechanical Engineering

University of Florida

Gainesville, Florida 32601 
School of Architecture

University of Colorado

Boulder, Colorado 80302

Miss Nancy K. Barberii

OCD Professional Advisory Service Center

University of Arizona

Tucson, Arizona 85721

Mr. Dick Kummer

101 Eng. A

Pennsylvania State University

University Park, Pennsylvania 16802

Director, Defense Atomic Support Agency

Attn: Jack R.Kelso

Washington, D. C. 20301

Director of Research and Development

Office of Emergency Preparedness

Washington, D. C. 20504

Director, Civil Effects Branch

Division of Biology and Medicine

Atomic Energy Commission

Attn: Mr. L. J. Deal

Washington, D. C. 20545

Mr. George N. Sisson, Director

Shelter Research Division

Office of Civil Defense

Department of the Army - OSA

Washington, D. C. 20310

Air Force Special Weapons Laboratory

Attn: Technical Library

Kirtland Air Force Base

New Mexico 87117

Los Alamos Scientific Laboratory

Attn: Document Library

Los Alamos, New Mexico 87544 
Chief of Engineers

Department of the Army

Attn: ENGME-RD

Washington, D. C. 20315

Chief, Joint Civil Defense Support Group

Office, Chief of Engineers

Department of the Army

Gravelly Point

Washington, D. C. 20315

Director, Army Materials and Mechanics Research Center

Attn: Technical Library

Watertown, Massachusetts 02172

Director, U.S. Army Ballistic Research Laboratory

Attn: Document Library

Aberdeen Proving Ground, Maryland 21005

Director, U.S. Army Ballistic Research Laboratory

Attn: Mr. William Taylor

Aberdeen Proving Ground, Maryland 21005

Director, Defense Atomic Support Agency

Attn: Technical Library

Washington, D. C. 20301

Director, U.S. Army Engineer Waterways

Experiment Station

Post Office Box 631

Attn: Nuclear Weapons Effects Division

Vicksburg, Miśsissippi 39180

Director, U.S. Army Engineer Waterways

Experiment Station

Post Office Box 631

Attn: Document Library

Vicksburg, Mississippi 39180

District Engineer, U.S. Army Engineer District, Omaha

Attn: Chief, Engineering Division

6012 U.S. Post Office and Court House

Omaha, Nebraska 68101 
Mr. Carl K. Wiehle

Civil Defense Technical Office

Stanford Research Institute

Menlo Park, California 94025

Mr. William L. White

Civil Defense Technical Office

Stanford Research Institute

Menlo Park, California 94025

Mr. Werner Weber

Director, New York State Civil Defense Commission

Public Security Building

State Office Building Campus

Albany, New York 12226

Agbabin-Jacobsen Associates

8943 South Sepulveda Boulevard

Los Angeles, California 90045

Amman and Whitney

111 Eighth Avenue

New York, New York 10011

Mr. Arthur D. Caster

Chairman, Coordinating Committee on Civil Defense

American Society of Civil Engineers

2864 McFarlan Park Drive

Cincinnati, Ohio 45211

The Dikewood Corporation

1009 Bardbury Drive, S. E.

University Research Park

Albuquerque, New Mexico 87106

General American Transportation Corporation

General American Research Division

7449 North Natchez Avenue

Niles, Illinois 60648

Huds on Institute

Quaker Ridge Road

Croton-on-Hudson, New York 10520 
Bell Telephone Laboratories, Inc.

Attn: Mr. R. W. Mayo

Whippany Road

Whippany, New Jersey 07981

Dr. Eugene Sevin

IIT Research Institute

10 West 35th Street

Chicago, Illinois 60616

Dr. 'Harold Brode

The RAND Corporation

1700 Main Street

Santa Monica, California 90401

Research Triangle Institute

P. O. Box 12194

Research Triangle Park,

North Carolina 27709

Mr. Luke J. Vortman

Division 5412

Sandia Corporation

Box 5800, Sandia Base

Albuquerque, New Mexico 87115

URS Research Company

1811 Trousdale Drive

Burlingame, California 94011

Massachusetts Institute of Technology

Department of Civil and Sanitary Engineering

Cambridge, Massachusetts 02138

Dr. Nathan M. Newmark

University of Illinois

111 Talbot Laboratory

Urbana, Illinois 61801

Dr. William Hall

University of Illinois

111 Talbot Laboratory

Urbana, Illinois 61801 
Dr. Merit P. White

University of Massachusetts

School of Engineering

Amherst, Massachusetts 01002

Dr. Abner Sachs

Institute for Defense Analyses

400 Army-Navy Drive

Arlington, Virginia 22202

The 'Vertex Corporation

10400 Connecticut Avenue

Kensington, Maryland 20795

Chief of Engineers

Department of the Army

Attn: ENGMC-EM

Washington, D. C. 20315

Dr. C. S. White

President-Director

Lovelace Foundation

5200 Gibson Boulevard, S. E.

Albuquerque, New Mexico 87108

Dr. Charles Osterberg

Acting Chief, Environmental Sciences Branch

Division of Biology and Medicine

U.S. Atomic Energy Commission

Washington, D.C. 20545

Mr. J. J. Davis

Effects Evaluation Division

Nevada Operations Office

U.S. Atomic Energy Commission

Las Vegas, Nevada 89101

Mr. Eugene F. Witt

Bell Telephone Laboratories, Inc.

Whippany Road

Whippany, New Jersey 07981

Mr. Paul Zigman

Enviroumental Science Associates

770 Airport Boulevard

Burlingame, California 94010 
President, Mississippi River Commission

ATTN: E. P. Blankenship

Vicksburg, Mississippi 39180 
Unclassified

Security Clansification

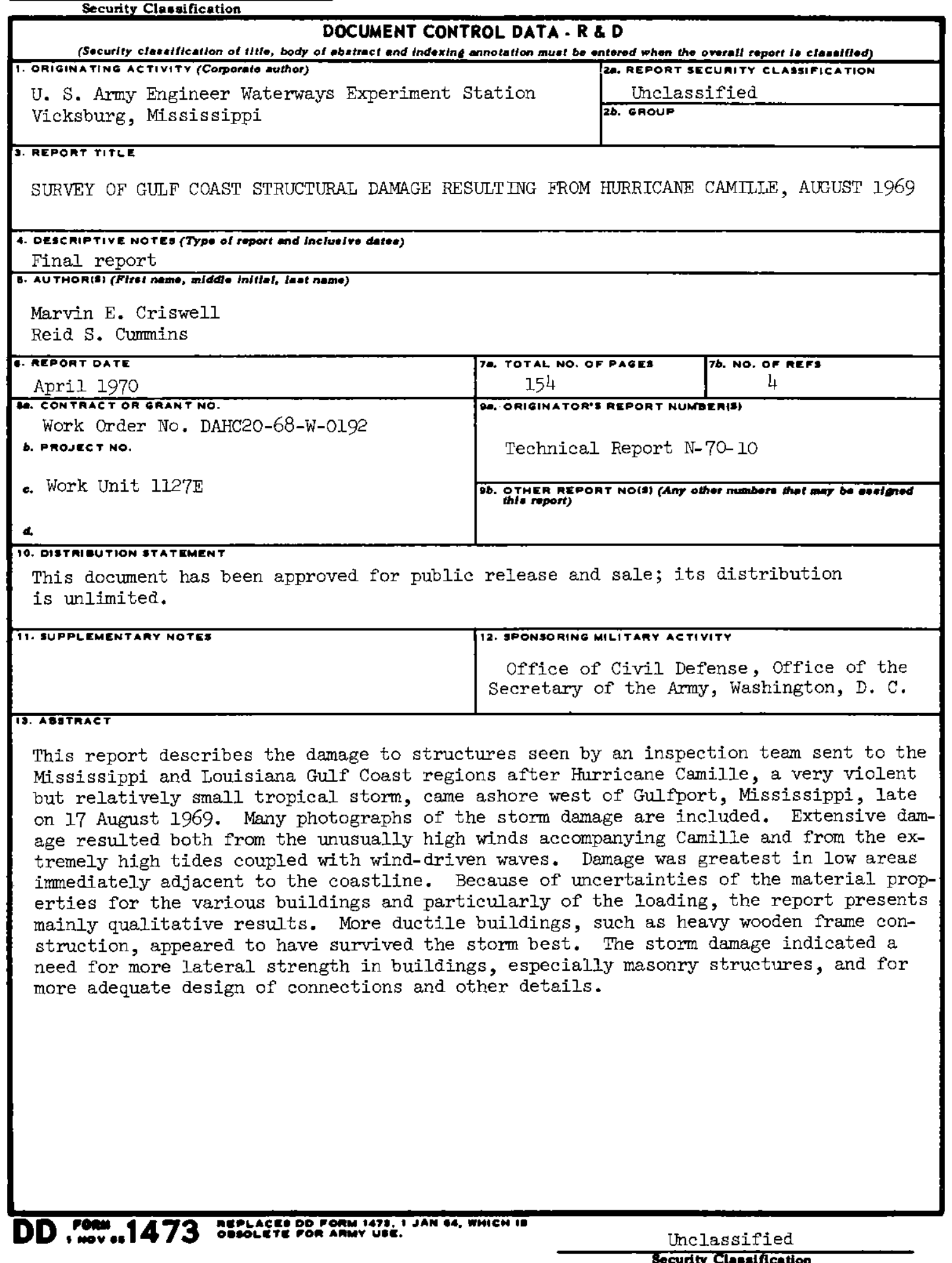


Unclassified

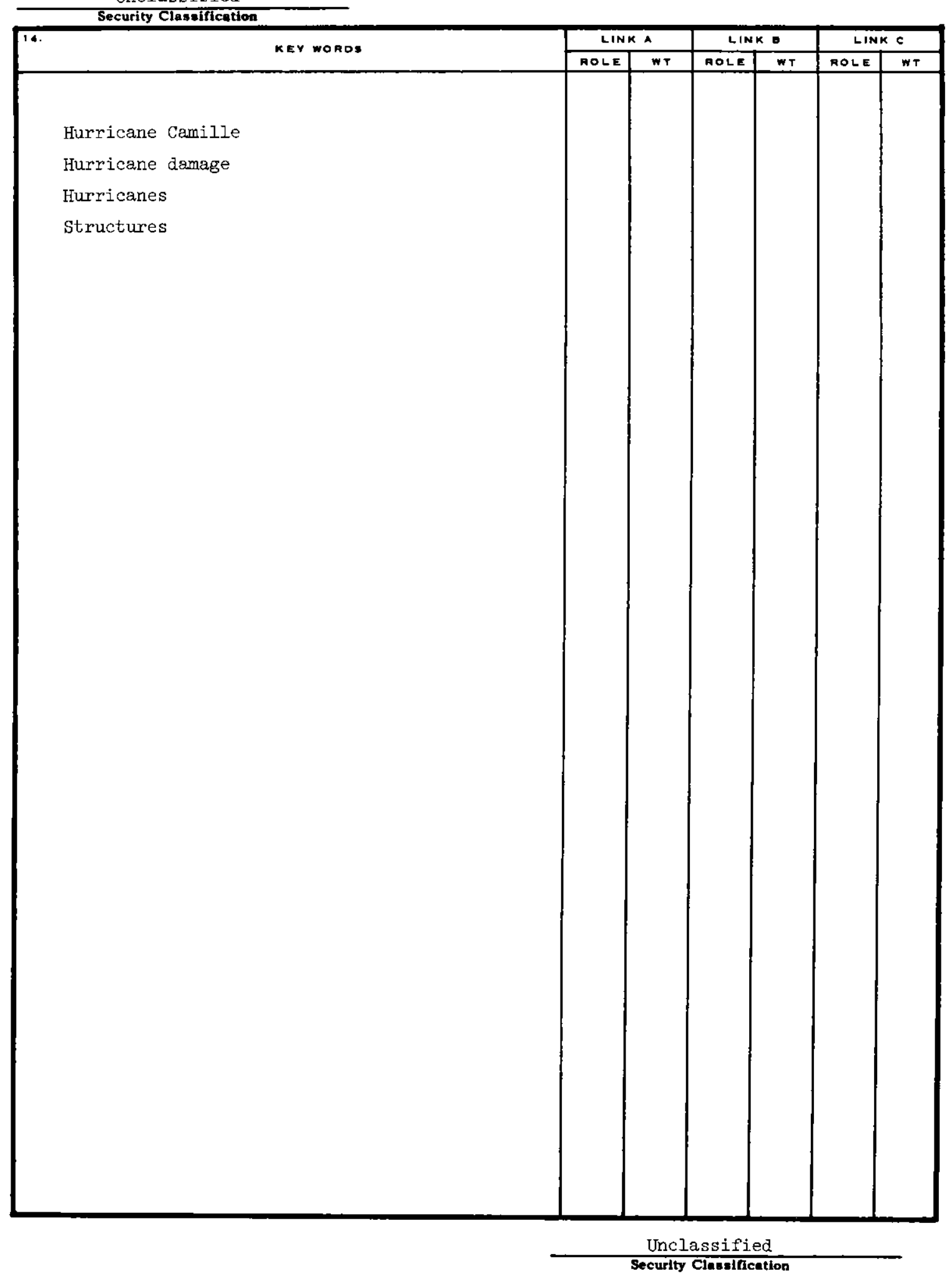


U. S. Arrny Engineer Waterways Experiment Station, CE, Vicksburg, Miss. SURVEY OF GULF COAST STRUCTURAL DAMAGE RESULTING FROM HURRICANE CAMLLLE, AUGUST 1969 , by M. E. Criswell and R. S. Cummins. Work Oraer No. DAHC20-68-W-0192

Work Unit $1127 \mathrm{~F}$

This report describes the damage to structures seen by an inspection team sent to the Mississippi and Louisiana Gulf Coast regions afte Hurricane Camille, a very violent but relatively small tropical storm, came ashore west of Gulfport, Mississippi, late on 17 August . Many photographs of the storm damage are included. Extensive camille and from the extremely high tides coupled with wind-drive waves. Damage was greatest in low areas immediately adjacent to the coastline. Because of uncertainties of the material properties for the various buildings and particularly of the losding, the report presents mainly qualitative results. More ductile buildings, such as heavy wooden frame construction, appeared to have survived the storm best. The storm danage indicated a need for more lateral. adequate design of connections and other details.

U. A. Army Engineer Waterways Experiment Station, CE, Vicksburg, Miss. SUBVEY OF GULF COAST STRUCTURAL DAMAGE RESULTING FROM
HURRICANE CAMILLE, AUGUST 1969 , by M. E. Criswell and R. $\mathrm{S}$. Curnnins. HURRICANE CAMILLE, AUGUST 1969, by M. E. Criswell and R. S. Cunnins Work Order No. DAHC20-68-W-0192

Work Order No.
Work Unit $1127 \mathrm{E}$

This report describes the danage to structures seen by an inspection team sent to the Mississippi and Louisiana Gulf Coast regions after Hurricane camille, a very violent but relatively small tropical storm, came ashore west of Gulfport, Mississippi, late on 17 August 1969. Many photographs of the storm damage are included. Extensive camille and from the extremely high tides coupled accompanying waves. Damage was greatest in low areas immediately adjacent to the coastline. Because of uncertainties of the material properties for the various buildings and particularly of the loading, the report presents mainly qualitative results. More ductile buildings, such as heavy wooden frame construction, appeared to have survived the storm best. The storm danage indicated a need for more lateral strength in buildings, especially masonry structurea
UNCLASSIFIED

1. Hurricane Camille

2. Hurricane damage

3. Hurricanes

\section{Criswell, M. E.}

Curmins, R. S.

Waterways Experiment
Station, Technical Report $\mathbb{N}-70-10$

\section{UNCLASSIFIED}

1. Hurricane Camille 2. Hurricane damage 3. Hurricanes

1. Criswell, M. E.

III. Cumins, R. S. Station, Technic日 Report $\mathrm{N}-70-10$
U. S. Army Engineer Waterways Experiment Station, CE, Vicksburg,

MUS. SURVEY OF GULF COAST STRUCTURAL DAMAGE RESULTING FROM April 1970, 154 pp. (Technical Report N-70-10)

$$
\text { : }
$$

Work Order No. DAHC20-68-W-0192

Work Unit $1127 \mathrm{~F}$

This report describes the damage to structures seen by an inspection team sent to the Mississippi and Louisiane Gulf Coast regions after Hurricane Camille, a very violent but relatively small tropical storm, came ashore west of Gulfport, Mississippi, late on 17 August 1969. Many photographs of the storm damage are included. Extensive damage resulted both from the unusually high winds accompanying
Camille and from the extremely high tides coupled with wind-drive - waves. Damage was greatest in low areas immediately adjacent to the - coastline. Because of uncertainties of the material properties for the various buildings and particularly of the loading, the report presents mainly qualitative results. More ductile buildings, such as heavy wooden frame construction, appeared to have survived the strength in buildings, especially masonry structures, and for more adequate design of connections and other details.

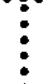

U. S. Army Engineer Waterways Experiment Station, CE, Vicksburg,

Miss. SURVEY OF GULF COAST STRUCTURAL DAMAGE RESULTTIT ROM

HURRICANE CAMIUUE, AUGUST 1969, by M. F. Cristell and R. S. Cunmins. April 1970, 154 pp. (Technical Report N-70-10)

Work Order NNo. DAHC20-68-W-0192

Work Unit 1l27E

This report describes the damage to structures seen by an inspection team sent to the Mississippi and Louisiana Gulf Coast regions after Hurricane Camille, a very violent but relatively small tropical - storm, came ashore west of Gulfport, Mississippi, late on 17 August : 196. Many photographs of the stosually high winds accomanying : Camille and from the extremely high tides coupled with wind-driven waves. Damage was greatest in low areas immediately adjacent to the coastine. Because of uncertainties of the material properties for the various buildings and particularly of the loading, the report presents mainly qualitative results. More ductile buildings, such as heavy wooden frame construction, appeared to have survived the storm best. The storm demage indicated a need for more lateral

- strength in bullaings, especially masonry structs
UNC LASSIFIER

1. Hurricane Camill 2. Hurricane damage 4. Hurricanes

I. Criswell, M. E.

II. Waunins, R. S. Station Report N-70-10

UNCLASS IFIED

1. Hurricane Camille . Hurricane dama 4. Structure

\section{Criswell, M. E.}

II. Curmins, R. S. Waterways Experiment Station, Technical 
<smiles>C1CC1</smiles> 

